\title{
Europeanization in Sweden
}

This open access library edition is supported by the University of Lund. Not for resale. 


\section{Studies on Civil Society}

\section{Editors: Dieter Gosewinkel and Holger Nehring}

Civil Society stands for one of the most ambitious projects and influential concepts relating to the study of modern societies. Scholars working in this field aim to secure greater equality of opportunity, democratic participation, individual freedom, and societal self-organization in the face of social deficits caused by globalizing neo-liberalism. This series deals with the multiple languages, different layers, and diverse practices of existing and emerging civil societies in Europe and elsewhere and asks how far the renewed interest in the concept can contribute to the gradual evolution of civil society in the wider world.

\section{Volume 1}

Languages of Civil Society

Edited by Peter Wagner

\section{Volume 2}

Civil Society: Berlin Perspectives

Edited by John Keane

\section{Volume 3}

State and Civil Society in Northern Europe: The Swedish Model Reconsidered Edited by Lars Trägårdh

\section{Volume 4}

Civil Society and Gender Justice: Historical and Comparative Perspectives

Edited by Karen Hagemann, Sonya Michel, and Gunilla Budde

\section{Volume 5}

Markets and Civil Society: The European Experience in Comparative Perspective Edited by Victor Pérez-Díaz

\section{Volume 6}

The Golden Chain: Family, Civil Society and the State

Edited by Jürgen Nautz, Paul Ginsborg, and Ton Nijhuis

\section{Volume 7}

Civil Society in the Age of Monitory Democracy

Edited by Lars Trägårdh, Nina Witoszek, and Bron Taylor

\section{Volume 8}

Transnational Struggles for Recognition: New Perspectives on Civil Society since the 20th Century

Edited by Dieter Gosewinkel and Dieter Rucht

\section{Volume 9}

Civil Society Revisited: Lessons from Poland

Edited by Kerstin Jacobsson and Elżbieta Korolczuk

\section{Volume 10}

Europeanization in Sweden: Opportunities and Challenges for Civil Society

Organizations

Edited by Anna Meeuwisse and Roberto Scaramuzzino 


\title{
EUROPEANIZATION IN SWEDEN
}

\section{OPPORTUNITIES AND CHALLENGES FOR Civil SOCIETY ORGANIZATIONS}

\author{
Edited by \\ Anna Meeuwisse and Roberto Scaramuzzino
}

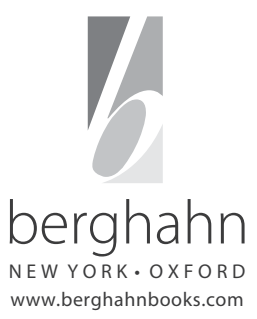

This open access library edition is supported by the University of Lund. Not for resale. 
First published in 2019 by

Berghahn Books

www.berghahnbooks.com

(C) 2019 Anna Meeuwisse and Roberto Scaramuzzino

All rights reserved. Except for the quotation of short passages for the purposes of criticism and review, no part of this book may be reproduced in any form or by any means, electronic or mechanical, including photocopying, recording, or any information storage and retrieval system now known or to be invented, without written permission of the publisher.

\section{Library of Congress Cataloging-in-Publication Data}

Names: Meeuwisse, Anna, 1958- editor. I Scaramuzzino, Roberto, editor.

Title: Europeanization in Sweden: Opportunities and Challenges for Civil

Society Organizations / edited by Anna Meeuwisse and Roberto Scaramuzzino.

Description: New York: Berghahn Books, 2019. | Series: Studies on Civil

Society; volume 10 | Includes bibliographical references and index.

Identifiers: LCCN 2018040253 (print) | LCCN 2018048814 (ebook) | ISBN

9781789200355 (ebook) | ISBN 9781789200348 (hardback: alk. paper)

Subjects: LCSH: European Union-Sweden. | Civil society-European Union countries.

Classification: LCC HC241.25.S8 (ebook) | LCC HC241.25.S8 E874 2019 (print) | DDC 320.609485-dc23

LC record available at https://lccn.loc.gov/2018040253

\section{British Library Cataloguing in Publication Data}

A catalogue record for this book is available from the British Library

ISBN 978-1-78920-034-8 hardback

ISBN 978-1-78920-983-9 open access ebook

\section{(c) (1) $\$ \Theta$}




\section{CONTENTS}

List of Tables

Carlo Ruzza

List of Abbreviations

Introduction: Europeanization, Civil Society, and the Swedish Welfare State

Anna Meeuwisse and Roberto Scaramuzzino

\section{Section I}

Chapter 1 Europeanization of and by Civil Society: Toward an Analytical Framework

Kerstin Jacobsson and Håkan Johansson

Chapter 2 The Dual Role of European Union Civil Society Organizations: Between European Union Institutions and Domestic Civil Societies

Håkan Johansson and Sara Kalm

\section{Section II}

Chapter 3 Europeanization of Swedish Civil Society: Motives, Activities, and Perceived Consequences Roberto Scaramuzzino and Magnus Wennerhag

Chapter 4 Factors Explaining Swedish Civil Society Organizations' Europeanization

Roberto Scaramuzzino and Magnus Wennerhag 
Chapter 5 Access to the European Union and the Role of Domestic Embeddedness

Elsa Hedling and Anna Meeuwisse

\section{Section III}

Chapter 6 Europeanization through Funding

Matteo Di Placido and Roberto Scaramuzzino

Chapter 7 From Popular Movements to Social Businesses: Social Entrepreneurship as Discursive Europeanization

Ulrika Levander

Chapter 8 Varying Degrees of Europeanization in Swedish

Women's Organizations

Ylva Stubbergaard

Chapter 9 Questioning the Swedish Model or Exporting It? Identity

Europeanization in the Prostitution Policy Field

Gabriella Scaramuzzino and Roberto Scaramuzzino

Chapter 10 Promoting Consumer Rights in Sweden by Lobbying and Awareness-Raising Abroad

Anna Meeuwisse and Andreas Vilhelmsson

Chapter 11 The Crisis of the European Union: Opportunity or Graveyard for a European Civil Society?

Lars Trägårdh

\section{Section IV}

Concluding Remarks

Anna Meeuwisse and Roberto Scaramuzzino

Appendixes

278

Roberto Scaramuzzino and Magnus Wennerhag

Index 


\section{TABLES}

1.1 A Typology of CSO Europeanization

2.1 Social Platform Participants' Membership: Type (Individual, National, and EU-level CSOs/International CSOs) and Country

2.2 Budget, Staff, and Funding Sources 56

2.3 Lobbying-Costs and Indicators 60

2.4 Main Lobbyists among Social Platform member EU-level CSOs: Ranking and Indicators 64

2.5 Relations to National Member Organizations 65

3.1 Ten Types of Organizations Analyzed in the Chapter 80

3.2 Some Basic Characteristics of the CSOs Included in the Analysis (in Percentages)

3.3 Perceived Importance of Various Forms of EU-related Influence (in Percentages)

3.4 Perceived Problems of Being a Member of a European Network (in Percentages)

3.5 Perceived Political Importance of the European Level (in Percentages)

3.6 Influencing Politicians and Officials at the European Level (in Percentages)

3.7 Use of Various Forms of Advocacy to Influence EU Policies (in Percentages)

3.8 Use of Various Forms of Advocacy to Influence Swedish Politics (in Percentages)

3.9 Membership in Networks, Federations, or Umbrella Organizations (in Percentages)

3.10 Importance of Different Sources of Funding (in Percentages)

3.11 Participation in Network-Based Activities at the EU Level (in Percentages)

3.12 Political Impact When Influencing Politicians and Officials at the European Level (in Percentages) 
3.13 Application for EU Funding (in Percentages) 103

4.1 Correlations between Different Forms of Europeanization 113

4.2 The Most Important Factors for the CSOs' Different Types of Europeanization (Binary Logistic Regression) 114

5.1 The Three P's of Elite Criteria 131

5.2 Distribution of Elite Criteria 131

5.3 Types of Organizations 132

5.4 Organizational Level 133

5.5 Activity at Different Political Decision-Making Levels 134

5.6 Memberships at the EU Level 135

5.7 Types of Participatory Activities 136

5.8 Activities of Policy Influence 139

5.9 Use of Direct or Semi-direct Strategies of EU Policy Influence 140

8.1 Extent of Europeanization Correlated to Dimensions of $\begin{array}{ll}\text { Participation } & 197\end{array}$

8.2 Crossing Membership between the BPW and SWL and Their Relations to Governmental and Intergovernmental Organizations in a Multilevel Perspective 199

9.1 The CSOs Involved in the Study 215

A.l Sample Size, the Sample's Relation to the Total Population, and the Response Rate 


\section{PREFACE}

\section{Carlo Ruzza}

The field of civil society, and particularly civil society in the context of international governance, has attracted significant attention in recent years and has produced a host of studies on the structure, strategies, and network connections of civil society organizations (CSOs). These studies have generated a body of literature that has acted as a catalyst for more general reflections on a range of related issues such as issues of political legitimacy, the normative role of associational representation, and the linkage between the state and society in different contexts. This book provides an updated reflection on several key issues initially tackled by this literature, but which are in need of a substantial update in view of the broader research agenda and the theoretical changes that have occurred in recent years. This book thus provides a novel look at processes such as the Europeanization of civil society in terms of its normative, financial, organizational, and political aspects.

Civil society-related themes have acquired a different character in the years since their prominent appearance in the literature more than two decades ago. For example, issues such as distrust of supranational bodies have become more salient, welfare states have shrunk, New Public Management approaches have expanded and changed, modifying the way CSOs are framed and funded, and the project of European integration has been undermined by a long financial and social crisis, which has questioned the legitimacy of EU-level funding. This book tackles these and several connected issues in the context of processes of Europeanization of civil society in Sweden.

The book takes its point of departure in the original literature on democracy and associational representation, and it integrates these early insights with the necessary awareness of recent changes in the socio-political situation in several EU countries and Sweden in particular. The book's specific emphasis is on the multifarious dimensions of Europeanization, which guides the study of the relations between civil society associations and governance bodies at different levels of government. This is particularly relevant given the historical reliance of Nordic countries on civil society associations 
and their inclusion in several functions of the state, such as the state's implementative, service provision, monitoring, agenda setting, and policy evaluation roles. The volume presents a set of interlinked chapters that all together provide a broad study of organized civil society conceptualized in an encompassing way and document the various ways in which Swedish civil society becomes Europeanized or fails to do so. Europeanization is understood not as an inescapable and benevolent process, as was sometimes the case in the early literature on multilevel governance, but as a complex actor-driven set of social dynamics in which a key role is played by the agency of private and collective actors, by sometimes fragmented and competing elites, and by their interactions in complex social fields. This is an important and distinctive contribution of this volume and approaching the field from this perspective allows the contributors to identify complex configurations of conflict and cooperation among different types of actors within and outside civil society. They are able to disentangle various dimensions of Europeanization and to document the different mixes of actors and issues that characterize each sector.

The contributors thus distance themselves from the early glorification of transnational spaces as integrative hubs of harmoniously nested territorial identities; instead, they frame Europeanization as a set of distinctive processes to be examined through a set of precise hypotheses that are then empirically addressed. This approach leads to some interesting counterintuitive findings and to a more accurate and realistic description of the scope and function of organized civil society. For instance, the contributors are able to document the internal tensions between competing territorial identities or between different framings of issues by different organized civil society communities. They note how localist views of participatory democracy are often in conflict with the previously dominant image of a trans-national EU, enriched by cultural diversity and cosmopolitan conceptions of citizenship. They point out that localism, in fact, often simply reframes the EU as a space of conflict among states and social organizations rather than as an alternative source of identities. Thus, this volume can be read as a reassessment of a previous and often almost utopian understanding of international civil society, and it enriches and qualifies civil society's characterization as an instrument for participative and deliberative democracy.

This volume retains a clear understanding and appreciation of the many virtues of organized civil society in complex chains of governance relations. For instance, it notes civil society's role in creating spaces of deliberation, preference formation, preference aggregation, and evaluation that supplement, integrate, and in some cases replace the spaces offered by representative democratic institutions. The contributors are aware of the limitations that hinder relations across levels of governance. The wide literature on 
governance and civil society is then summarized and integrated into comprehensive schemes, such as the typology presented in chapter 1 by Kerstin Jacobsson and Håkan Johansson.

Chapter 2, by Håkan Johansson and Sara Kalm, focuses on the central issue of Europeanization in terms of its organizational, financial, and regulatory aspects. It clearly describes the multiple flows of information, resources, and policy frames and pinpoints their targets and intermediaries, thereby identifying and analyzing bottom-up and top-down dynamics among CSOs at different levels of governance. This chapter is important because it provides needed factual information on both the financial and regulatory aspects of organized civil society and its inter-organizational relations, which are too often neglected by the literature on Europeanization.

Questions related to the complex ways in which different types of Europeanization interact, which are raised in the introduction and first two chapters, are again addressed in chapters 3 and 4-with particular reference to Swedish civil society-based on a large dataset that allows the authors to address these questions in empirical terms. Roberto Scaramuzzino and Magnus Wennerhag examine responses to a survey involving 2,791 organizations of several different kinds, and thanks to such a large number of cases they are able to compare organizations that perform rather different functions, but also some similar ones, and are therefore able to examine key issues such as perceptions of representational effectiveness, organizational aggregative functions, and institutional interactions. They document the centrality of the grassroots level for several organizations, and in some cases they note these organizations' difficulties in connecting to other levels of government and they note the relevance of international cooperation beyond the EU, including regional Nordic organizations and international organizations such as the UN. This approach is important because it rebalances a literature that is too often largely theoretical with only limited or even anecdotal empirical evidence. The authors' broad sectoral selection is particularly interesting because it allows them to examine how institutional bodies relate to different mixes of organizations with different levels of legitimacy, acceptability across the left-right axis, resource bases, and the centrality of the advocacy or service delivery function. Thus, their sample includes Disability organizations, Temperance and drug users' organizations, Trade unions, Victim support organizations, Women's organizations, and other interest organizations. They also include more diffused interests, such as humanitarian and religious groups. Among the organizations that are rarely compared to interest groups of different kinds, this survey interestingly includes political parties, thereby offering the opportunity to address key issues of representation and legitimacy that are rarely debated across such different kinds of actors. In several contexts, recent debates have identified 
one of the roots of the expansion of the voluntary sector in the crisis of political formations, and of political parties in particular. The possibility to compare perceptions of these two kinds of political participation is therefore of particular value.

Another example of an empirically based examination of the contributions of civil society to national and international governance is Elsa Hedling and Anna Meeuwisse's chapter on embeddedness, which touches on the long-standing debate on the advantages and limitations of institutionalization. They address key issues, such as whether domestic embeddedness in national institutional realms translates into EU-level embeddedness and more generally into the ability to relocate to the supranational level and gain relevant access. As the two contributors point out, this is an issue that has been conceptualized differently within the literature, with some authors arguing that the lack of a solid basis in national institutional realms stimulates Europeanization and others arguing the opposite, that is, that national embeddedness facilitates transnational institutionalization. Their analysis offers the possibility to settle this long-standing dispute and to provide needed additional details about mechanisms of associational embedding in different realms. As in other chapters, their examination of Europeanization is nuanced, distinguishing participatory aspects from financial and organizational aspects. They show how embeddedness is mediated by key variables such as ideological proximity of CSOs and institutional domains, by levels of professionalization, and by path-dependent variables such as previous high levels of access and a related insider status. Through this lens, they show the relative marginalization of religious and lifestyle groups and the elite status of political and service organizations. They then show how national embeddedness translates more easily into Europeanization, but not for local organizations. More generally, they frame issues of embeddedness in terms of what these issues tell us about the evolution of the Swedish model of state-civil society relations and the related changes in the nature of the embedded elites that characterize this model. That is, they document how the advantage of learning strategies for embeddedness at the national level translates into similar skills being more easily developed at the supranational level.

Chapters 6 and 7 document and discuss aspects of Europeanization that have only recently been explored. Chapter 6 by Matteo DiPlacido and Roberto Scaramuzzino focuses on funding dynamics. It investigates five organizations that have been granted funding through the European Social Fund (ESF) and analyzes both the selection mechanisms that facilitate access to ESF funding and the outcomes of such funding. Like other recent studies, it documents the 'projectification' of organized civil society's activities and explores the distinct impact that this has for Swedish civil society. It documents the diverse set of motives that lead CSOs to seek EU funding and the 
factors that determine which applications are selected for funding, including personal acquaintances with EU officials and an in-depth understanding of the political realm in which funding decisions are taken. In other words, it illustrates the type and scope of the cultural and social capital necessary to be a successful player in EU competitions for funding. As in other chapters, the specificity of the Swedish model, and in particular the relative ease of access to national funding opportunities, emerges as a powerful filter that shapes the structure of Swedish civil society by limiting its dependency on financial Europeanization.

The following chapter, by Ulrika Levander, reflects on the implication of a relatively recent development in the structure and function of civil society whereby its traditional reliance on volunteering is increasingly being integrated with the acceptance and pursuit of market efficiency and for-profit organizational models. The rapidly diffusing model of social entrepreneurship has become institutionalized at the EU level because it is a model that is better connected with the dominant neoliberal ethos of $\mathrm{EU}$ policymaking. More broadly, this model legitimizes private market actors and their role in functions that were previously often left to volunteering, and it encourages the formation of private-public networks of providers and envisages a system of multiactor consultations and coregulation of public services. These approaches are often justified in terms of increased efficiency and increased representation of broader societal sectors. This chapter describes the impact of this emerging ethos on Swedish civil society, and in particular it focuses on its discursive impact, that is, the ways in which the framing of issues in Sweden has changed in accord with changing EU models. The emerging ethos consists of a redefinition of the contents and policy style of the welfare state, which is now seen as being based on civil society actors as socially legitimized entrepreneurial welfare providers. Ulrika Levander-the chapter's author-makes use of the theoretical framework of sociological neo-institutionalism, through which she identifies isomorphic pressures on Swedish organized civil society but also possibly a characteristic disconnect between discourses and practices.

The chapter by Ylva Stubbergaard continues the review of styles and sources of Europeanization with attention to a field in which national preferences have often been successfully uploaded to the EU level. This chapter is important because it provides needed information not only on which organizations are Europeanized, but also on which ones are not. And for those that are not, it describes the mix of ideological and organizational reasons that prevent these organizations from relocating at least part of their activities to the supranational level. The field of civil society and governance generally focuses on successful examples of Europeanization, which provides important research findings. However, studying negative 
examples is equally crucial and possibly even more relevant in the current period of crisis in the process of European construction and the consequent reluctance of some organizations to consider the EU as a source of funding and legitimacy.

In the following chapter, which focuses on the controversial topic of which legal framework is to be advocated for the regulation of prostitution, Roberto Scaramuzzino and Gabriella Scaramuzzino study the relation between the feminist EU-level umbrella group "Women's lobby" and the Swedish-level member group, which unlike other member groups believes that prostitutes' clients should be prosecuted. The authors show that specific variables are key to the successful uploading of preferences, including the centrality of a specific issue for a member group, the status of that group in the umbrella organization, and the desire of the umbrella group not to escalate tensions with prominent member groups. This research is important because it indicates the complex mix of cooperation and conflict that exists among and between organized civil society groups, a topic that was only occasionally considered in the previous literature.

The crucial theme of the constraints that vested interests impose on the activities of organized civil society is taken up again in the following chapter by Anna Meeuwisse and Andreas Vilhelmsson. Using a joint political opportunities and framing perspective, these authors investigate the impact of the pharmaceutical industry and the medical profession on setting and maintaining norms in the face of challengers from organized civil society. This case study focuses on advocacy attempts by patients' organizations that are concerned about the side effects of a class of drugs called serotoninreuptake inhibitors. The chapter demonstrates how organized institutional actors have been able to defeat attempts at normative redefinitions and therefore dismiss the advocacy efforts of organized civil society. The authors point to the dissuasive impact of the Swedish welfare state tradition on the individual rights espoused by organizations such as the one examined in this chapter. An unsuccessful outcome is also linked to the types of grievances that emerge in the health-care field within which powerful epistemic communities emerge and are cemented by a strong resource base and shared expertise.

The chapter by Lars Trägårdh brings the volume to a close with some more general reflections on organized civil society in the Swedish context and a reassessment of its role in the current period of crisis. It interprets current developments as challenging for supporters of a stronger role of civil society. This interpretation can only be shared in a period of reemerging nationalism in many national contexts and mounting skepticism of the role of international institutions in general and of the role of organized civil society within such institutions. 
Taken together, the chapters in this volume give us a very clear picture of the evolution of state-society relations, focusing on the changing role of civil society as a set of organizations, as a complex body of intermediary institutions, and as an evolving contribution to democratic governance. It provides a rich analysis of the differentiated sectoral role of organized civil society in the specific national context of Sweden. Several chapters discuss the changes that have occurred in recent years in our framing of the political and policy role of civil society. The book is both theoretically ambitious and empirically rich, using different methodologies and contributing rich research outcomes that will be essential to further advance our understanding of the governance role of organized civil society.

Carlo Ruzza (MA SUNY, PhD Harvard) is Professor of Political Sociology at the University of Trento in Italy where he teaches courses on European and International Politics and on Political Sociology. He has previously taught at the Universities of Leicester, Essex and Surrey. His research interests focus on populism, social movements, right wing parties and European Studies. His book publications include with Stefano Fella Reinventing the Italian Right: Populism, Post-Fascism and Territorial Identity (Routledge, 2009) and Europe and Civil Society (Manchester University Press, 2007). He has also published widely in refereed journals and published several edited books. 


\section{ABBREVIATIONS}

AGE

ALTER-EU

BEUC

BPW

BPWE

BWPI

CEC

CECOP-CICOPA

CEDAW

COFACE

CONCORD

$\mathrm{CSO}$

DG

DHR

EAPN

EaSI

EASPD

EC

ECDN

ECI

ECOSOC

ECSWR
AGE Platform Europe

Alliance for Lobbying Transparency and Ethics

Regulation

European Consumer Organisation (Bureau

Européen des Unions de Consommateurs)

Business and Professional Women

BPW Europe

BWP International

Commission of the European Communities

European Confederation of Workers'

Cooperatives, Social Cooperatives and Social and Participative Enterprises

Beijing Platform for Action on the Elimination of all forms of Discrimination against Women Confederation of Family Organisations in the European Union

Confederation for Relief and Development civil society organization

directorate-general

Delaktighet, Handlingskraft, Rörelsefrihet

European Anti-Poverty Network

European Programme for Employment and

Social Innovation

European Association of Service Providers for

Persons with Disabilities

European Commission

European Consumer Debt Network

European Citizens' Initiative

UN Economic and Social Council

European Conference for Social Work

Research 
EDF

EES

EESC

ENAR

ENSIE

EP

EPA

EPHA

EPR

ESAN

ESF

EU

EUCIS-LLL

EUCORD

EURAG

EUROCIV

EURORDIS

EWL

Famna

FEANTSA

FEFAF

Forum

HAI

Housing Europe

HRDN

ICRSE

ICSW

IFSW

ILGA
European Disability Forum

European Employment Strategy

European Economic and Social Committee

European Network Against Racism

European Network of Social Integration

Enterprises

European Parliament

European Parents Association

European Public Health Alliance

European Platform for Rehabilitation

European Social Action Network

European Social Fund

European Union

European Civil Society Platform on Lifelong Learning

European Cooperative for Rural Development European Federation of Older People

Beyond the Welfare State-Europeanization of Swedish Civil Society Organizations (research program)

European Organisation for Rare Diseases

European Women's Lobby

The Swedish Association for Non-Profit Health and Social Service Providers

European Federation of National Organisations working with the Homeless

European Federation of Unpaid Parents and

Carers at Home

The National Forum for Voluntary Organizations

Health Action International Europe

The European Federation of Public, Cooperative and Social Housing

Human Rights and Democracy Network

International Committee for the Rights of Sex

Workers in Europe

International Council on Social Welfare

International Federation of Social Workers

International Lesbian, Gay, Bisexual, Trans, and

Intersex Association

Individuell Människohjälp

IM

INCLUSION EUROPE The European Association of Societies of Persons with Intellectual Disability and Their Families 


$\begin{array}{ll}\text { IOGT } & \text { International Organisation of Good Templars } \\ \text { IPPF } & \text { International Planned Parenthood Federation } \\ \text { IUT } & \text { The International Union of Tenants } \\ \text { KILEN } & \text { Consumer Association for Medicines and Health } \\ \text { LGBT } & \text { lesbian, gay, bisexual, and transgender } \\ \text { LO } & \text { Swedish Trade Union Confederation } \\ \text { MEP } & \text { Member of the European Parliament } \\ \text { MHE } & \text { Mental Health Europe } \\ \text { MSM } & \text { men having sex with men } \\ \text { MUCF } & \text { Swedish Agency for Youth and Civil Society } \\ \text { NGO } & \text { Non-Governmental Organization } \\ \text { PICUM } & \text { Platform for International Cooperation on } \\ & \text { Undocumented Migrants } \\ \text { PRIS } & \text { Prostitutes' Revenge in Society } \\ \text { RFSL } & \text { Swedish Federation for Lesbian, Gay, Bisexual, } \\ & \text { and Transgender Rights } \\ \text { RFSU } & \text { Swedish Association for Sexuality Education } \\ \text { RIFFI } & \text { Swedish Federation of Immigrant Women's } \\ & \text { Associations } \\ \text { ROSEA } & \text { now Rose Alliance } \\ \text { Saco } & \text { Swedish Confederation of Professional } \\ & \text { Associations } \\ \text { SIDA } & \text { Swedish International Development Cooperation } \\ & \text { Agency } \\ \text { SSRIs } & \text { selective serotonin-reuptake inhibitors } \\ \text { SWL } & \text { Swedish Women's Lobby } \\ \text { TCO } & \text { Swedish Confederation of Professional } \\ \text { Employees } \\ \text { TGEU } & \text { Transgender Europe } \\ \text { UMC } & \text { Uppsala Monitoring Centre } \\ \text { UN Women } & \text { United Nations Entity for Gender Equality and } \\ \text { the Empowerment of Women } \\ \text { UN Women Sweden } & \text { Swedish National Committee for UN Women } \\ \text { UNAIDS } & \text { Joint United Nations Programme on HIV/AIDS } \\ \text { WAGGGS } & \text { World Association of Girl Guides and Girl } \\ \text { WHO } & \text { Scouts Europe Region } \\ \text { WISE } & \text { World Health Organization } \\ \text { YFJ } & \text { Work Integration Social Enterprise } \\ & \\ & \text { Europ Youth Forum } \\ & \end{array}$




\title{
EuropeaniZATION, Civil SocIETy, AND THE SWEDISH WELFARE STATE
}

\author{
Anna Meeuwisse and Roberto Scaramuzzino
}

One might argue that the project of European integration has come a long way. Proofs of this statement are the rise and expansion of the European Union (EU) and the development of a common financial policy and currency. Furthermore, free movement of goods and people within the EU has been introduced along with a common system of border control. Recent developments on the European continent have, however, cast serious doubts on the stability of the project. The financial crisis of 2009, the refugee crisis of 2015, and the UK's decision to leave the EU in 2016 (Brexit) have put a strain on European cooperation and highlighted conflicts between and within countries, damaging the reputation and legitimacy of the EU and its public institutions. These crises have also sparked a mobilization of citizens in the EU countries and across borders within the anti-austerity movement and the refugee-welcome movement. Nationalist movements have also expanded in opposition to both European integration and immigration. While these crises have demonstrated the vulnerability of European cooperation, that cannot be taken for granted, they have also shown the existence of a common European public sphere for citizen mobilization around issues of public interest.

The concept of Europeanization has often been used to describe and explain the development of the EU and individual member states, not least in the debate on the future of the EU (Olsen 2002). The EU now affects 
virtually every policy area to a greater or lesser extent, and Europeanization is understood as a process of change in both the domestic setting and at the EU level where resources and opportunities are redistributed. Europeanization has also become a common approach to understanding the inclusion and role of civil society in the EU (see, e.g., De Schutter 2002; Kröger 2016; Rek 2007; Smismans 2003; Trenz 2007; Warleigh 2001). Europeanization has implied both opportunities and challenges for civil society organizations (CSOs) across Europe, and one consequence of Europeanization is the rise of an EU-based civil society with its roots in national civil societies but organized at the supranational level (e.g., Johansson and Kalm 2015). For domestic organizations, the rise of an EU-based civil society has, among other things, meant new possibilities of participation, not least through EU-based organizations, as well as new funding opportunities. New opportunities at the European level have resulted in a more complex political environment where CSOs are acting in a multileveled setting and might be more or less likely to engage in EU activities to strengthen their resources and positions (Kendall 2009; Kohler-Koch and Quittkat 2009; Marks and McAdam 1996).

This book explores the Europeanization of domestic CSOs in Sweden. The concept of civil society is often used for highlighting a specific social sphere that is separate from the state, the market, and the family. Civil society and its functions in liberal democracies have been theorized from different perspectives, and sometimes in terms of expressions of different types of social contracts (Somers 1995; Trägårdh 2007). The Hegelian tradition emphasizes the function of civil society for channeling particular interests in society and the state's responsibility to subsume and transform them into universal and rational interests. According to the Tocquevillian tradition, on the other hand, civil society is a space of freely coordinated and organized individual interests and hence has the role of keeping at bay the more coercive forms of power embodied by the state. The role of civil society has also been related to different ways of organizing the welfare system and hence to so-called welfare regimes (Esping-Andersen 1990). The Swedish understanding of civil society and its role, which is embodied in the Swedish welfare model, has sometimes been considered to conflict with the ideological and normative frames on which the EU project is based. By opening new channels for political influence, by allocating resources and funding for CSOs, and by spreading new norms and ideas, EU institutions may be seen as a challenge to the Swedish model and to the social contract on which this model is based. This is one of the main reasons why Sweden provides an interesting national context for the study of the Europeanization of domestic civil society.

CSOs might use EU institutions to challenge national or local policies and regulations but might also use resources at the local and national level 
(contacts, funding, and institutions) to wield influence in Brussels. Few cases of EU regulations have engaged so many Swedish CSOs as the EC VAT Directive. According to Swedish law, many CSOs are VAT exempted, a privilege that organizations are eager to preserve. But in 2008 the European Commission (EC) addressed Sweden with a formal notice that the special VAT rules for CSOs were contrary to the EC VAT Directive (Cederholm 2013). Many prominent Swedish civil society actors in close collaboration with the Swedish government strongly opposed the ruling for six years until finally, at the beginning of 2015, the EC dropped the VAT issue. On the one hand, this episode can be interpreted as a clash between a European understanding of civil society as part of a social economy sector and a Swedish tradition of popular movements (folkrörelser), fueling EU skepticism among Swedish CSOs. On the other hand, voices claiming that Sweden should leave the EU have been few, and Swedish CSOs have instead interacted with the EU and its institutions to convince the EC to change its mind. One could say that Swedish CSOs chose protest instead of exit.

In addition to being a potential regulatory actor in a Swedish context, the EU also represents a potential new source of funding for many CSOs and an alternative to the Swedish system of public funding. Projects in partnership with different constellations of public and private nonprofit and for-profit actors are often sponsored and cofinanced by the EU, for example by the European Social Fund (ESF) in the area of integration in the labor market. Ironically, EU-funded rural groups seem to be especially active in areas where EU skepticism is strongest. They often use EU funding to strengthen citizen initiatives of self-governing and self-reliance aiming at maintaining the "sub-municipal territorial base of citizen identities" (Amnå 2006, 8).

Furthermore, many Swedish civil society representatives frequently visit Brussels, trying to influence EU institutions to adopt common rules on specific issues such as trafficking of human beings or to force the Swedish government to conform to EU directives, such as concerning the protection of endangered species. These few examples show different ways in which the EU has proven to be relevant for Swedish civil society sector by creating funding opportunities, by offering an arena for influence in policy areas, and by regulating the relationship between public authorities and national and local voluntary organizations.

In this book we understand Europeanization as a two-sided process in which the EU influences domestic actors, but where domestic actors also take advantage of the opportunities offered by the EU. It is reasonable to ask whether and to what extent the new opportunities offered by the EU are realized to their full potential; Europeanization also raises questions about the costs of interacting with public institutions at the European level. There are significant challenges for local and even national CSOs to interact with 
the EU institutions, and it requires both the skills and capacity to be able to mobilize resources from the EU funding system and to wield influence in Brussels. The degree to which Swedish CSOs participate in the opportunities offered by the EU institutions might be influenced not only by the division of responsibility between the nation-state and the EU (Beyers and Kerremans 2007), but also by the organizations' commitment and the organizational and administrative skills that are required. Resources in terms of organization, expertise, and finances are said to set the standards of the EU game. The European level has sometimes been referred to as an elite project, consultation practices with nonstate actors have often been initiated by invitation only, and funding opportunities are bound to certain conditions that might imply adaptation to specific rules and regulations set up by EU institutions (Best, Lengyel, and Verzichelli 2012). As highlighted by Fligstein (2008), however, the creation of a common European public sphere transcends the mere building of common European public institutions to which civil society actors might or might not have access. Europeanization is in fact both a political project driven by the national and European public institutions and a social phenomenon driven by spontaneous interactions and cooperations between nonstate actors (both enterprises and CSOs).

\section{The Idea of a European Civil Society}

While transnational cooperation among European countries does not necessarily imply the creation of a new political entity and European-level public institutions, the project of building the EU by integrating nation-states on the European continent is, in a liberal interpretation, linked to the creation of a common public space. Europeanization as such is, however, not necessarily linked to liberalism; it has been understood as a sometimes coercive and violent expression of antiliberal conceptions of Europe, for instance, in the former communist Eastern bloc (Gosewinkel 2015; see also Conway and Patel 2010 for a historical perspective). While illiberal understandings of Europeanization do not need a civil society to rest on, a liberal conception of Europe, that we would argue is dominant in the understanding of EU institutions, does. A civil society as a social sphere separate from the state and the market was in fact the foundation from which the state's legitimacy was claimed in the development of the modern liberal nation-state (Swyngedouw 2005). What is peculiar with the EU project is that it can instead be argued to anticipate the existence of a European (civil) society and thus the need to create one.

The idea of constructing a European civil society can be associated with the model of communitarian democracy in which demos, here the people 
of Europe, with common values and identities are supposed to lay the foundation of demo-cracy (Tomšič and Rek 2008; Finke 2007). Communitarian democracy is, however, very closely connected to nations and the idea of culturally common belonging. In order to foster a sense of common European identity, a socializing mechanism is necessary. The idea is that it would be possible to develop common European values through a European civil society resting on domestic organizations working on local levels (SánchezSalgado 2007). One could argue, however, that such a project is in conflict with a recurring image of a transnational $\mathrm{EU}$ characterized by cultural diversity and a cosmopolitan view of citizenship. It also downplays the EU as a space of conflict and negotiation between states and between social movements and CSOs over national interests and the meaning of Europeanness (cf. Schierup, Hansen, and Castles 2006).

How does Europeanization occur in practice? Is it sparked at the institutional level from above, or does it spring from initiatives at the grassroots level from below? Turning the gaze from the political process and formal decisions to the way in which people actually interact across Europe, Neil Fligstein $(2008,1)$ asserts, "The growing cooperation amongst the people in Europe is now underpinned by a large number of Europe-wide fields of action, social fields where organized groups, be they governments, firms, nonprofit organizations, or interest groups of citizens from countries across Europe have come together for common purposes" (see also Kaiser and Meyer 2013). These types of horizontal linkages and ties are, however, unevenly distributed among Europeans. While a few, often upper- and middle-class, Europeans are deeply involved with other Europeans on a daily basis or more infrequently, the rest have little or no contact with people in other countries. Thus, the EU project as an elite project creates a tension or a gap between those who are Europeanized and those who are not (Fligstein 2008).

While economic integration has often been seen as opposed to the creation of a European social dimension (e.g., Schierup, Hansen, and Castles 2006), Fligstein (2008) argues that economic integration has been and still is a precondition for social interaction and cooperation among citizens and organizations across the borders of the nation-states. One of the key mechanisms is that with European integration, interest groups have become aware that decisions that are relevant to them are taken at a European level. To be able to affect such decisions, these groups have to be present in Brussels. As interest groups across Europe have realized that they have common interests, interaction and cooperation outside Brussels have also become a necessary step. However, not all interests have become Europeanized. While Europeans generally have accepted the idea that issues such as border controls, mobility of goods and services, and the protection of the environment 
are to be handled by the EU, they have not agreed to what extent welfare issues such as pensions or unemployment benefits should be decided in Brussels (Fligstein 2008).

As discussed earlier in this introduction, recent events have challenged this development. The refugee crisis of 2015 has led to a temporary reintroduction of border controls between member states. These measures are a consequence of an unresolved conflict over the extent to which EU countries should grant refugee status and protection to migrants and how the settlement of the migrants should be distributed. In Sweden the debate around migration has clearly been linked to the welfare state and to the so-called costs of open borders and a generous refugee policy, a reframing that potentially positions the migration issue as a matter for national authorities.

While these developments challenge a view of Europeanization as a linear process of progressive integration, research on Europeanization has clearly demonstrated a continuous rise and development of CSOs at the European level (e.g., Johansson and Kalm 2015). Umbrella organizations, platforms, and networks for CSOs have been established and tend to interact with other CSOs as well as with public institutions. Many of them have headquarters in Brussels. Among these actors, we also find CSOs engaged in social welfare issues like women's rights, poverty, homelessness, integration, racism, and so on. This may be seen as a direct effect of an increasing interest of EU institutions in social policy issues. As European integration has spread, the EU has gradually broadened its ambitions and increasingly approached social areas that have previously been national concerns (Heidenreich and Zeitlin 2009; Hvinden and Johansson 2007; Kvist and Saari 2007). A common social policy agenda has, in fact, for some time been the foundation for EU institutions' efforts to harmonize national policies. The process of setting a common agenda began as early as the 1980s; since the late 1990s a common strategy for a European employment policy has been in place.

Today there are EU policies in areas such as poverty, social exclusion, health care, and pensions (Borrás and Jacobsson 2004; Jacobsson and Johansson 2009). These regulations at the supranational level are often framed in terms of antidiscrimination and equal treatment rather than in terms of social rights linked to citizenship as is often the case in Sweden (cf. Schierup, Hansen, and Castles 2006). Because these areas are considered politically sensitive, the ambition has seldom been to produce binding legislation; however, the EU has sought to influence developments in member states by involving CSOs as a means of strengthening the EU's legitimacy and facilitating the implementation of supranational decisions (Saurugger 2007). Hence, although its mandate in the area of social policy is still limited, the EU has created new opportunities for CSOs by actively recruiting them in the effort to increase integration in this policy area and to legitimize 
the EU as a democratic construction (Finke 2007; Heidbreder 2012, 2015; Kohler-Koch and Finke 2007). Political processes at the EU level, such as the antidiscrimination clause in the Amsterdam Treaty, the Open Method of Coordination on social policy, and the creation of national action plans on social inclusion, have all engaged domestic CSOs (see Erneberg 2015 for an overview). Still we have little knowledge about how these activities are linked to civil societies at the national level and to the domestic actors interacting within these networks at the EU level. This volume aims to contribute to filling this knowledge gap.

\section{Researching Europeanization and Civil Society Organizations}

Research on EU civil society and CSOs operating at the EU level has expanded considerably over the past decade. Even if this research has mainly focused on what takes place in Brussels and less so on the Europeanization processes, they still have relevance for the topics raised in this book. There is extensive research on the democratic quality of an EU-based civil society and in particular on CSOs representing various interests at the EU level (e.g., Kohler-Koch 2009; Kröger 2013; Kröger and Friedrich 2012; Rodekamp 2014; Steffek and Hahn 2010; Steffek, Kissling, and Nanz 2008; Tomšič and Rek 2008; Trenz 2009). Scholars argue that the participation of CSOs follows a transmission belt model, meaning that EU-based CSOs could be transmitters of EU information to domestic members and/or actors while acting as a collector of knowledge and information from the domestic level and bringing it into the EU debate (see further discussion below). Authors in this volume have questioned this model in recent empirical research (e.g., Johansson and Lee 2014; Johansson and Schütze 2014). Johansson and Lee $(2014$, 412), for example, discuss the "representational gaps" between EU-based organizations and their national members and argue that only "a limited number of members might in practice exercise full participatory rights in internal authorization and accountability processes."

Scholars have also explored the role played by EU institutions in promoting and interacting with civil society actors at various levels. Much research has been carried out on the governance arrangements used by the different EU institutions (mainly the EC) vis-à-vis CSOs (mainly those operating at the EU level) (Greenwood 2007a, 2007b; Kohler-Koch 2009; Smismans 2003, 2008; Trenz 2009). These scholarly debates have revealed the EC's entrepreneurial role and shown that over the years it has both indirectly and directly mobilized and/or set up associations of civil society in various policy fields it has deemed relevant (Bouwen 2009; Coen and Richardson 2009; Kohler-Koch and Finke 2007; Sánchez-Salgado 2007). The EU's forms of 
financial, technical, and ideational support have encouraged scholars to talk of participatory engineering in order to capture this remarkable bureaucratic activism (Kohler-Koch and Finke 2007). Studies have also explored the EC's explicit preference for certain selected representative organizations at the EU level and pointed out its administrative as well as strategic preference for a limited set of peak organizations that are operating in Brussels and acting as the EC's selected partners (e.g., Armstrong 2002; Greenwood and Halpin 2007; Greenwood 2007b).

Another strand of research pays much more attention to strategies that CSOs, mainly interest groups operating at the EU level, deploy to make claims and seek political leverage. Studies demonstrate that EU-based CSOs tend to use insider strategies and to engage in activities such as lobbying, legal actions, expert opinions, position papers, conferences, and participation on various advisory or consultative committees rather than more-confrontational activities such as demonstrations and protests (Balme and Chabanet 2008; Cullen 2003; Kriesi, Tresch, and Jochum 2007; Sánchez-Salgado 2007; Saurugger 2006). Such strategies have mainly been used by the set of institutionalized CSOs operating in Brussels (Cullen 2010). Partly related to this line of research are the studies on the Europeanization of protest and social movement activities (e.g., della Porta and Caiani 2007, 2009; Imig and Tarrow 2001; Ruzza and Bozzini 2008; Teune 2010)-in other words, whether the claims and targets of social movements have a European dimension. This strand of research has seen the EU as an emerging political opportunity structure that international and domestic CSOs and social movements act on and react to (e.g., Marks and McAdam 1996). This structure includes, among other things, financial, political, and legal opportunities (Marks and McAdam 1996). Changes in the social and political environment might therefore bring about not only improved access to material resources, but also political and administrative elites' recognition as legitimate participants and an improved scope for political representation. The EU's advancements in fields such as environmental concerns, disability policies, and gender equality have given birth to a number of analyses of how the EU encourages agency in the forms of social movements or other types of transnational activism (e.g., Imig and Tarrow 2001). Findings suggest, among other things, homogenizing effects on social movement groups and organizations as they enter into the EU sphere and adopt similar organizational structures, high levels of professionalism, similar types of resources, and a politically neutral discourse (Ruzza 2011).

The literature on interest groups and social movements entails work that studies the impact of Europeanization on both CSOs and on the member states. One discussion concerns the extent to which the EU empowers 
domestic CSOs by providing new avenues for influence, funding, and networking opportunities. Engaging in a multilevel game may allow CSOs to bring pressure on their national policymakers from the outside through the so-called boomerang effect (Keck and Sikkink 1998) or ping-pong effect (Zippel 2004), going back and forth from the EU to the national level with their demands. The EU has also been found to affect the domestic opportunity structures for CSOs. An effect of EU funding, for instance, has been a differentiation between the haves and have-nots in civil society where large organizations or organizations belonging to umbrella organizations often have the administrative capacity to apply for funding while smaller organizations do not (e.g., Rek 2010; Roth 2007).

Research about the EU's influence on Swedish CSOs and on Swedish organizations' activities at the EU level are scarce and seem to point in different, partly discordant directions. A study published in 2009 (Olsson et al. 2009) suggests that Europeanization in Sweden is quite modest because of the mismatch between the social democratic values so central to the Swedish model and the perceived character of the EU as an institution. Our own previous studies on the former EU-funded EQUAL Community Initiative (2000-6) suggest that quite a few Swedish voluntary organizations in the social welfare area have been able to mobilize EU funding and hence strengthen their position in their organizational field of activity (Scaramuzzino et al. 2010; Scaramuzzino 2012). Several of the initiatives within the structural funds have been based on requirements of partnerships between nonprofit, public, and private organizations, and participation in these partnerships has led to an (at least temporary) increase in financial resources for some of the organizations.

Because of an alleged mismatch between the EU and Sweden and the close relationships between Swedish CSOs and public institutions, Swedish organizations might be expected to be less incentivized to seek political influence and to mobilize resources at the European level. Domestic embeddedness might, however, also trigger Europeanization because organizations that have access to opportunity structures at the local and national levels more than organizations that do not have that access have the resources necessary for influencing and mobilizing at the European level. Furthermore, access to several layers of opportunity structures potentially diminishes the risk for organizations of becoming too dependent and eventually co-opted by local, national, and EU institutions. It should also be kept in mind that civil society is not a homogeneous, consensus-based, social field; rather, it is characterized by contention and competition (Johansson and Kalm 2015). For CSOs that are at odds with the normative stands of the Swedish state, Europeanization might actually appear to be a viable option for accessing resources, legitimacy, and potentially political influence, not only at the 
European level but also in the domestic setting. We will analyze if and how organizations lacking conventional resources can Europeanize, what strategies they adopt and develop to compensate for resource shortages, and whether they manage to achieve political leverage.

\section{Europeanization and the Swedish Model}

Research on the Europeanization of civil society suggests that the environment, and particularly the relationship to the national and local governments, sets the scope of conditions for CSOs' engagement with the EU (Beyers 2002; Buzogány 2013; Cram 2001). Sweden has always had an ambivalent relationship with the EU. Sweden has been a member of the EU since 1995, but this membership has never been uncontroversial. The referendum for joining the EU passed by only a small majority, and a proposal on joining the common currency in 2003 was turned down by the Swedish voters in another referendum.

In this sense Sweden represents yet another awkward partner in the EU family (Johansson 2003) following the same pattern as the UK in its "sense of detachedness and removal from EU institutions" (Olsson et al. 2009, 178). Some argue that the Swedish EU skepticism has its roots in a profound mismatch between the way in which the EU institutions are perceived and core values in the Swedish polity as institutionalized in the welfare model: "Whatever its claimed advantages in terms of economic development and employment generation, the EU has been seen as insufficiently open, democratic and social citizenship oriented, both in terms of the substance and style of its policies" (Olsson et al. 2009, 178).

Not least the Swedish popular movements, the backbone of organized civil society in the country, have been critical of potential changes brought by EU influence on national and local welfare policies (Olsson et al. 2009, 179). Accordingly, the social contract on which European integration is based-informed by notions such as federalism and subsidiarity-poses a threat to the way in which the Swedish model conceives the relationship between the state, the individual, and civil society (Trägårdh 2007). The Swedish civil society sector has been defined through the concept of popular movements rather than third sector, social economy, or other concepts used in central and southern Europe. The notion of popular movements emphasizes the democratic function of Swedish CSOs rather than their significance in economic terms, with a focus on membership and representativeness rather than on service production and employment (Olsson et al. 2009). However, despite a recognized strong role and responsibility of the state in crucial areas such as social welfare, Swedish civil society is vibrant 
in terms of the number of organizations (Lundström and Wijkström 1997; Wijkström and Einarsson 2006), the civic engagement of citizens (Svedberg, von Essen, and Jegermalm 2010), and the creation of social trust (Trägårdh et al. 2013).

Swedish national identity is tightly linked to the welfare state and to a "Swedish model [that is] characterized by a particular form of statism built on a vision of a social contract between a strong and good state, on the one hand, and emancipated and autonomous individuals, on the other" (Trägårdh 2007, 27-28). The underlying idea is that the alliance between the state and the individual would liberate the latter from dependency on institutions in civil society such as the family, the churches, and charitable organizations. In line with this perspective on Sweden, cross-national comparisons of civil society have identified a specific Nordic, social democratic model characterized by extensive state-sponsored and state-delivered social welfare protections that leave little room for service-providing CSOs. Most organizations instead have a more prominent role as vehicles for expressions of political, social, or recreational interests (Salamon and Anheier 1998). Scandinavian civil society has hence traditionally functioned to "strengthen representative democracy through political socialization and a legitimacy-delivering corporatist arrangement” (Amnå 2006, 3). The participative and deliberative character of this model has been emphasized in which "not least the unions, the cooperative movement, and the employers' organizations-co-govern Swedish society in close but free cooperation with the representatives of state" (Trägårdh 2007, 2).

The Swedish neo-corporatist welfare model has by tradition been based on close alliances between the state and civil society (Micheletti 1995; Lundström and Wijkström 1997; Lundström and Svedberg 2003). Up until the 1930s, most welfare service provision in Sweden was organized and delivered by traditional charity organizations. With the development of the welfare state, public authorities eventually took over many of these organizations' social service provisions. In the social welfare domain, the division of responsibilities between the public and the civil society sector has been quite clear, even if it was never really formalized: while the public sector would provide the welfare services, the civil society sector would be advocating for interest groups' rights, critically scrutinizing the functioning of the public sector, and formulating new ideas. This model earned strong support in public opinion, including within the civil society sector itself, and advocacy, evaluation, and innovation are the domains in which Swedish welfare organizations have been most active (Olsson et al. 2009; see also Lundström and Svedberg 2003; Lundström and Wijkström 1997). Swedish CSOs have, for instance, challenged the Swedish government regarding welfare rights and have been influential in pushing for workers' rights, women's 
rights, and the rights of migrants, older and disabled people, and so forth (e.g., Lundström and Wijkström 1997; Micheletti 1995).

The often-noted similarities among the Nordic countries in terms of their welfare systems and in the role of their civil society can be related to similar societal features and historical developments concerning class structure, the role of the labor movements, and the role of the Lutheran church (e.g., Esping-Andersen 1990; Salamon and Anheier 1998; Trägårdh 2007). There has also been a tradition of inter-Nordic cooperation. This tradition of openness toward neighboring social-democratic countries coupled with a general suspicion of influences from countries belonging to different social and welfare models makes Sweden intriguing to study from a Europeanization perspective. However, European integration has coincided with important changes in the Swedish welfare system.

\section{Europeanization of Swedish Civil Society between Continuity and Change}

Since becoming a member of the EU, the Swedish welfare state has undergone considerable shifts, and the terms and opportunities for Swedish CSOs have changed. This development consists of a whole new openness to the idea that people's needs for welfare can be satisfied in other ways than through the state-in other words, that responsibility for welfare can be divided among different actors, including CSOs (e.g., Hartman 201 1; Svallfors 2015). The changes in the Swedish welfare system can be argued to be a product of both exogenous factors such as globalization, Europeanization, and international migration and of endogenous factors such as individualization, a weakening legitimacy of the welfare state, and demographic changes (Jaeger and Kvist 2003). It is remarkable that the debate around EU membership and the debate about the role of Swedish civil society took place at the same time in the 1990s. These heated debates also engaged the same actors, social movements, and political forces gathering around quite polarized positions. One side argued against EU membership and against a role of civil society as a service provider, and the other in favor of Swedish membership and for a liberalization of the Swedish welfare system (cf. Trägårdh 2007).

Whether these changes in the Swedish welfare state have simply coincided with EU membership or are a result of Europeanization is of course debatable. However, this does remind us that Europeanization might imply not only new opportunities that domestic actors can strategically choose to use, but also new forms of influence and regulation to which CSOs have to adapt. Today, the third sector in Sweden is recognized as critical for the future of care provision and, as many researchers have pointed out, there 
has been a shift in which the service function is much more stressed-a redirection from voice to service (Lundström and Wijkström 2012). The government wants public, private, and third-sector producers to participate in all areas of the welfare system, albeit through publicly funded service production. External service delivery options have been made possible through reforms inspired by the principles of privatization and marketization, that have allowed for nonstate actors-both for-profit and nonprofit-to produce social welfare service on behalf of the public sector. In order to strengthen the third sector and to create an environment of diversity where public, private, and third-sector producers participate and compete in all areas of the welfare system, efforts have also been made to conclude general agreements between the public sector and different parts of the third sector (Johansson 2011 ; Johansson, Kassman, and Scaramuzzino 2011). However, there has been confusion and disagreement about roles and positions along with worries about how agreements of this kind will affect the independence and integrity of the organizations.

Some of these trends might actually be traced back to processes at the European level. The development toward a more pluralistic political system has, for example, been influenced by EU membership as well as by international best-practice models from outside the EU framework (e.g., the Swedish compact; Johansson and Johansson 2012). New concepts and organizational logics have been introduced to the Swedish civil society sector, not least through the many funding programs of the ESF such as the EQUAL Community Initiative (Scaramuzzino et al. 2010).

Swedish CSOs act in a transformed political environment where processes of European integration contribute to a development where the national setting is just one among many in a complex and multilayered political context. The once unchallenged role of the nation-state is hence downplayed through external influences from supranational governance and international regulations, while at the same time the political arena is opened for a number of new societal actors (Hvinden and Johansson 2007).

While the social welfare policy area is still highly dependent on national regulations, the municipalities (kommuner) enjoy far-reaching autonomy in Sweden. The Swedish welfare system in fact embraces important local variations. The extent to which social services have been privatized, for example, vary between different municipalities (Svallfors 2015). This means that Europeanization might be more or less evident in different parts of the country, a variance that research also suggests. The institutionalization of the concept of social economy through EU funding seems, for instance, to be much more pronounced in the northern rural regions of Sweden where "EU regional and local development support is disproportionally concentrated" (Olsson et al. 2009, 167). It is in this changing environment that 
Swedish CSOs must be understood if we want to grasp the processes and mechanisms behind Europeanization.

\section{Our Contribution}

This book is a product of the joint effort of a research team linked to the research program Beyond the Welfare State-Europeanization of Swedish Civil Society Organizations (EUROCIV) financed by the Swedish Research Council. The program adopted a multimethodological design, including a survey among Swedish CSOs, answered by more than 2,700 organizations, and a number of qualitative case studies.

We are interested in whether and to what extent CSOs are interacting with institutions and organizations at the European level, the forms and conditions of such interactions, and the versatile dynamics that Europeanization involves and produces. European integration implies adaptation to common rules and norms. We argue that Sweden is a particularly interesting case of Europeanization because the Swedish view on the role of the state, civil society, and solidarity stands in contrast with many values at the base of the European integration project. The perceived mismatch between the norms and values informing the Swedish model and the EU integration program, as well as recent developments in the Swedish welfare state, makes Sweden particularly interesting for the study of Europeanization. It also motivates a focus on the policy area of social welfare. We make a broad interpretation of social welfare and include not only service production or charity work but also mobilization and organization of marginalized groups and advocacy for their rights.

Some of the organizations that this book deals with could be portrayed as lacking conventional organizational resources such as finances, administrative structures, legal expertise, contacts, lobbying skills, and large membership bases. Due to their representation of marginal groups, they might have difficulties in attracting resources from members or from external funders. Such organizations stand in sharp contrast to much common understanding of what it takes for domestic organizations (profit and nonprofit) to successfully mobilize on the EU level.

We understand Europeanization as a two-way process in which the EU influences domestic actors, but where domestic actors also make use of the EU. This approach should not be understood as focusing on the way in which the EU affects the nation-state and vice-versa, but rather as highlighting the interaction between agents and structures. The focus will be on Swedish CSOs as agents in an institutional context that is placed on different geographical levels-from the local to the European-and that provides 
both opportunities and constraints. We hence interpret Europeanization as a process that might be both enabling and constraining for CSOs, producing both opportunities and increased regulation.

We also want to contribute to the discussion about Europeanization by means of a multidimensional approach that, we argue, gives us a nuanced understanding of the processes involved. We acknowledge that Europeanization might encompass several dimensions, so we have developed a typology that enables us to distinguish different aspects of Europeanization, including regulatory, financial, and organizational influence as well as discursive, participatory, and identity impacts (see chapter 1). Our definition of Europeanization is hence broad and includes many different activities that relate to the European level. We are interested in the linkages between Swedish organizations and the social fields at the European level; those linkages imply a broader approach to Europe than merely the EU institutions (see also Johansson and Kalm 2015). From the point of view of many CSOs that we discuss in this book, the boundary between the EU and Europe and between Europeanization and internationalization may be blurred or even irrelevant.

Furthermore, we consider CSOs as a set of institutions carrying different, sometimes opposing, normative frames. Civil society is hence a social sphere characterized by contention rather than consensus. Much research has focused on the relation between civil society and the state. Our approach is interactional and pays attention to dynamics of contention, competition, and cooperation between CSOs.

This introduction is followed by a two-chapter section made up of a theoretical chapter and a context chapter. The second section, also comprising three chapters, presents and discusses results from the EUROCIV survey while the third section presents a set of qualitative case studies. All of the empirical chapters explore different types and dimensions of Europeanization: in other words, regulatory, financial, organizational, discursive, participatory and identity Europeanization, drawing on the typology presented in chapter 1 . The chapters are based on different types of data and focus on different types of organizations and policy issues ranging from labor market integration, gender equality, and prostitution, to health and consumer rights. For the purpose of addressing these topics each chapter develops its own theoretical framework, all more or less explicitly drawing on the political opportunity structure approach. This approach is combined with agency-focused theoretical perspectives and concepts such as resource mobilization, framing and so on, in order to also address the organizations as agents of Europeanization. In Section IV, Concluding Remarks, the editors briefly sum up the results of the studies, relating them to the overall themes of the volume outlined in this chapter. 
Anna Meeuwisse is Professor of Social Work at Lund University, Sweden. One of her research areas concerns the changing roles of CSOs in the welfare state. She has been engaged in several research projects regarding civil society, advocacy, and transnational social movements in the health and welfare area.

Roberto Scaramuzzino is Researcher at Lund University, Sweden. His research interests include changes in the welfare and integration systems and the role of CSOs in different countries. He has been engaged in comparative studies of mobilization in the migration and prostitution policy fields in Sweden and Italy, and at the EU level. He is currently working in a research program on civil society elites in Europe.

\section{References}

Amnå, Erik. 2006. "Still a Trustworthy Ally? Civil Society and the Transformation of Scandinavian Democracy." Journal of Civil Society 2, no. 1: 1-20.

Armstrong, A. Kenneth. 2002. "Rediscovering Civil Society: The European Union and the White Paper on Governance." European Law Journal 8, no. 1: 102-32.

Balme, Richard, and Didier Chabanet. 2008. European Governance and Democracy: Power and Protest in the EU. Lanham, MD: Rowman and Littlefield.

Best, Heinrich, György Lengyel, and Luca Verzichelli, eds. 2012. The Europe of Elites: A Study into the Europeanness of Europe's Political and Economic Elites. Oxford, UK: Oxford University Press.

Beyers, Jan. 2002. "Gaining and Seeking Access: The European Adaptation of Domestic Interest Associations.” European Journal of Political Research 41, no. 5: $585-612$.

Beyers, Jan, and Bart Kerremans. 2007. "Critical Resource Dependencies and the Europeanization of Domestic Interest Groups." Journal of European Public Policy 14, no. 3: 460-81.

Borrás, Susana, and Kerstin Jacobson. 2004. "The Open Method of Co-ordination and New Governance Patterns in the EU." Journal of European Public Policy 1 1: 2.

Bouwen, Pieter. 2009. "The European Commission.” In David, Coen, and Jeremy, Richardson, Lobbying the European Union, 19-38.

Buzogány, Aaron. 2013. "Stairways to Heaven or Highway to Hell?” In Protest Beyond Borders: Contentious Politics in Europe Since 1945, edited by Hara Kouki and Eduardo Romanos, 69-85. New York, NY: Berghahn Books.

Cederholm, Maria. 2013. Europeanization of Domestic Civil Society Organizations. Master's thesis. Lund, Sweden: Lund University.

Coen, David, and Jeremy Richardson. 2009. Lobbying the European Union: Institutions, Actors and Issues. Oxford, UK: Oxford University Press.

Conway, Martin, and Klaus Kiran Patel, eds. 2010. Europeanization in the Twentieth Century; Historical Approaches. Basingstoke, UK: Palgrave Macmillan.

Cram, Laura. 2001. "Governance 'To Go': Domestic Actors, Institutions and the Boundaries of the Possible." Journal of Common Market Studies 39, no. 4: 595-618. 
Cullen, Pauline. 2003. "Sponsored Mobilization: European Union Non-Governmental Organizations, International Governance and Activism for Social Rights." PhD diss., Stony Brook, State University of New York.

— 2010. "The Platform of European Social NGOs: Ideology, Division and Coalition." Journal of Political Ideologies 15, no. 3: 317-31.

De Schutter, Olivier. 2002. "Europe in Search of Its Civil Society." European Law Journal 8, no. 2: 198-217.

della Porta, Donatella, and Manuela Caiani. 2007. "Europeanization from Below? Social Movements and Europe." Mobilization 12, no. 1: 1-20.

- 2009. Social Movements and Europeanization. Oxford: Oxford University Press.

Erneberg, Anna. 2015. "The Europeanization of Civil Society: A Research Overview." EUROCIV report 2015-1. Lund, Sweden: Lund University.

Esping-Andersen, Gøsta. 1990. The Three Worlds of Welfare Capitalism. Cambridge, UK: Polity.

Finke, Barbara. 2007. "Civil Society Participation in EU Governance." Living Reviews in European Governance 2.

Fligstein, Neil. 2008. Euroclash: the EU, European Identity, and the Future of Europe. Oxford, UK: Oxford University Press.

Gosewinkel, Dieter. ed. 2015. Anti-liberal Europe: A Neglected Story of Europeanization. New York, NY: Berghahn Books.

Greenwood, Justin. 2007a. Interest Representation in the European Union (2 ed.). Basingstoke, UK: Palgrave Macmillan.

_ 2007b. "Review Article: Organized Civil Society and Democratic Legitimacy in the European Union.” British Journal of Political Science 37, no. 2: 333-57.

Greenwood, Justin, and Darren Halpin. 2007. "The European Commission and the Public Governance of Interest Groups in the European Union: Seeking a Niche between Accreditation and Laissez-faire." Perspectives on European Politics and Society 8, no. 2: 189-210.

Hartman, Laura. ed. 2011 . Konkurrensens konsekvenser-Vad händer med svensk välfärd. Stockholm, Sweden: SNS.

Heidbreder, G. Eva. 2012. "Civil Society Participation in EU Governance." Living Reviews in European Governance 7, no. 2: 1-42.

- 2015. "Governance in the European Union: A Policy Analysis of the Attempts to Raise Legitimacy through Civil Society Participation." Journal of Comparative Policy Analysis: Research and Practice 17, no. 4: 359-77.

Heidenreich, Martin, and Jonathan Zeitlin. 2009. Changing European Employment and Welfare Regimes: The Influence of the Open Method of Coordination on National Reforms. London, UK: Routledge.

Hvinden, Björn, and Håkan Johansson, eds. 2007. Citizenship in the Nordic Countries: Dynamics of Choice, Duties and Participation in a Changing Europe. London, UK: Routledge.

Imig, R. Douglas, and Sidney Tarrow. 2001. Contentious Europeans: Protest and Politics in an Emerging Polity. New York, NY: Rowman and Littlefield.

Jacobsson, Kerstin, and Håkan Johansson. 2009. "The Micro-politics of the OMC Process: NGO Activities and the Social Inclusion Process in Sweden." In Heidenreich and Zeitlin, Changing European Employment and Welfare Regimes.

Jaeger, Mads Meier, and Jon Kvist. 2003. "Pressures on State Welfare in Post-industrial Societies: Is More or Less Better?” Social Policy and Administration 37, no. 6: 555-572. 
Johansson, Håkan, and Mairon Johansson. 2012. "From a 'Liberal' to a 'Social democratic' Welfare State: The Translation of the English Compact into a Swedish Context." Nonprofit Policy Forum 3, no. 2: article 6.

Johansson, Håkan, and Sara Kalm, eds. 2015. EU Civil Society. Patterns of Cooperation, Competition and Conflict. Basingstoke, UK: Palgrave Macmillan.

Johansson, Håkan, Aanders Kassman, and Roberto Scaramuzzino. 2011 . Staten och det civila samhällets organisationer i ett föränderligt valfärdssamhälle. Stockholm, Sweden: Överenskommelsen.

Johansson, Håkan, and Jayeon Lee. 2014. "Bridging the Gap: How Do EU-based Civil Society Organisations Acquire Their Internal Representation?" VOLUNTAS: International Journal of Voluntary and Nonprofit Organizations 25, no. 2: 405-24.

Johansson, Håkan, and Carolin Schütze. 2014. "An Arena for the Elite? Member Participation in EU-based Civil Society Organisations.” Unpublished paper, submitted to the Journal of Civil Society.

Johansson, Karl Magnus. 2003. "Sweden: Another Awkward Partner?" In Fifteen into One? The European Union and Its Member States, edited by Wolfgang Wessels, Andreas Maurer, and Jürgen Mittag, 369-87. Manchester, UK: Manchester University Press.

Johansson, Mairon. 2011. "I dialogens namn-idén om en överenskommelse mellan regeringen och ideella organisationer." $\mathrm{PhD}$ diss. Växjö, Sweden: Linnaeus University.

Kaiser, Wolfram, and Jan-Henrik Meyer, eds. 2013. Societal Actors in European Integration; Polity-building and Policy-making 1958-1992. Basingstoke, UK: Palgrave Macmillan.

Keck, E. Margaret, and Kathryn Sikkink. 1998. Activists Beyond Borders: Advocacy Networks in International Politics. Cambridge, UK: Cambridge University Press.

Kendall, Jeremy, ed. 2009. Handbook on Third Sector Policy in Europe. Multi-level Processes and Organized Civil Society. Cheltenham, UK: Edward Elgar.

Kohler-Koch, Beate. 2009. "The Three Worlds of European Civil Society: What Role for Civil Society for What Kind of Europe?" Policy and Society 28, no. 1: 47-57.

Kohler-Koch, Beate, and Barbara Finke. 2007. "The Institutional Shaping of EU-Society Relations: A Contribution to Democracy via Participation?" Journal of Civil Society 3, no. 3: 205-21.

Kohler-Koch, Beate, and Christine Quittkat. 2009. "What Is Civil Society and Who Represents Civil Society in the EU? Results of an Online Survey among Civil Society Experts." Policy and Society 28, no. 1: 11-22.

Kriesi, Hanspeter, Anke Tresch, and Margit Jochum. 2007. "Going Public in the European Union: Action Repertoires of Western European Collective Political Actors." Comparative Political Studies 40, no. 1: 48-73.

Kröger, Sandra. 2013. "Creating a European Demos? The Representativeness of European Umbrella Organisations.” Journal of European Integration 35, no. 5: 583-600.

- 2016. Europeanised or European? Representation by Civil Society Organisations in EU Policy Making. Colchester, UK: ECPR Press.

Kröger, Sandra, and Dawid Friedrich. 2012. The Challenge of Democratic Representation in the European Union. New York, NY: Palgrave Macmillan.

Kvist, Jon, and Juho Saari. 2007. The Europeanization of Social Protection. Bristol, UK: Policy Press.

Lundström, Tommy, and Lars Svedberg. 2003. "The Voluntary Sector in a Social Democratic Welfare State: The Case of Sweden." Journal of Social Policy 32: 217-238. 
Lundström, Tommy, and Filip Wijkström. 1997. The Non-profit Sector in Sweden. Manchester, UK: Manchester University Press.

— . 2012. "Från röst till service: vad hände sedan?.” In Civilsamhället i samhällskontraktet, edited by Filip Wijkström, 245-287. Stockholm, Sweden: European Civil Society Press.

Marks, Gary, and Doug McAdam. 1996. "Social Movements and the Changing Structure of Political Opportunity in the European Union." Journal of West European Politics 19: 249-78.

Micheletti, Michele. 1995. Civil Society and State Relations in Sweden. Aldershot, UK: Avebury.

Olsen, P. Johan 2002. “The Many Faces of Europeanization.” Journal of Common Market Studies 40, no. 5: 921-52.

Olsson, Lars-Erik, Marie Nordfeldt, Ola Larsson, and Jeremy Kendall. 2009. "Sweden: When Strong Third Sector Historical Roots Meet EU Policy Processes.” In Kendall, Handbook on Third Sector Policy in Europe, 159-183.

Rek, Mateja. 2007. "Organised civil society in the multi-level system of European Governance." In Social Capital and Governance: Old and New Members of the EU in Comparison, edited by Adam Frane, 151-74. Berlin, Germany: LIT-Verlag.

- 2010. "Europeanization of Civil Society Sector in Central and Eastern Europe." Innovative Issues and Approaches in Social Sciences 3, no. 1: 160-86.

Rodekamp, Meike. 2014. Their Members' Voice: Civil Society Organisations in the European Union. Wiesbaden, Germany: Springer Fachmedien.

Roth, Silke. 2007. "Sisterhood and Solidarity? Women's organizations in the Expanded European Union." Social Politics: International Studies in Gender, State and Society 14, no. 4: 460-87.

Ruzza, Carlo. 2011. "Social Movements and the European Interest Intermediation of Public Interest Groups.” Journal of European Integration 33, no. 4: 454-69.

Ruzza, Carlo, and Emanuela Bozzini. 2008. "Organised Civil Society and European Governance: Routes of Contestation." European Political Science 7, no. 3: 296-303.

Salamon, M. Lester, and Helmut K. Anheier. 1998. "Social Origins of Civil Society: Explaining the Nonprofit Sector Cross-nationally." International Journal of Voluntary and Nonprofit Organisations 9, no. 3.

Sánchez-Salgado, Rosa. 2007. "Giving a European Dimension to Civil Society Organizations.” Journal of Civil Society 3: 253-69.

Saurugger, Sabine. 2006. "The Professionalisation of Interest Representation: A Legitimacy Problem for Civil Society in the EU?" In Civil Society and Legitimate European Governance, edited by S. Smismans, 260-276. Cheltenham, UK: Edward Elgar.

—. 2007. "Democratic 'Misfit'? Conceptions of Civil Society Participation in France and the European Union." Political Studies 55: 384-404.

Scaramuzzino, Roberto, Cecilia Heule, Håkan Johansson, and Anna Meeuwisse. 2010. EU och den ideella sektorn-En studie av det svenska Equalprogrammet. FoU Report 2010-2. Malmö, Sweden: Malmö University.

Scaramuzzino, Roberto. 2012. Equal Opportunities? A Cross-National Comparison of Immigrant Organisations in Sweden and Italy. PhD diss. Malmö, Sweden: Malmö University Health and Society Doctoral Dissertations. 
Schierup, Carl-Ulrik, Peo Hansen, and Stephen Castles. 2006. Migration, Citizenship and the European Welfare State: A European Dilemma. Oxford, UK: Oxford University Press.

Smismans, Stijn. 2003. "European Civil Society: Shaped by Discourses and Institutional Interests." European Law Journal 9, no. 4: 473-95.

- 2008. "New Modes of Governance and the Participatory Myth." West European Politics 31, no. 5: 874-95.

Somers, R. Margaret. 1995. "Narrating and Naturalizing Civil Society and Citizenship Theory: The Place of Political Culture and the Public Sphere." Sociological Theoryl3, no. 3: 229-74.

Steffek, Jens, Claudia Kissling, and Patrizia Nanz. 2008. Civil Society Participation in European and Global Governance: A Cure for the Democratic Deficit? Basingstoke, UK: Palgrave Macmillan.

Steffek, Jens, and Kristina Hahn. 2010. Evaluating Transnational NGOs : Legitimacy, Accountability, Representation. Basingstoke, UK: Palgrave Macmillan.

Svallfors, Stefan. 2015. "Politics as Organized Combat." Discussion Paper 15, no. 2, Cologne, Germany: Max Planck Institute for the Study of Societies.

Svedberg, Lars, Johan von Essen, and Magnus Jegermalm. 2010. Svenskarnas engagemang är större än någonsin: insatser i och utanför föreningslivet. Stockholm, Sweden: Ersta Sköndal Högskola.

Swyngedouw, Erik. 2005. "Governance Innovation and the Citizen: The Janus Face of Governance-beyond-the-State." Urban Studies 42, no. 11: 1991-2006.

Teune, Simon, ed. 2010. The Transnational Condition. Protest Dynamics in an Entangled Europe. New York, NY: Berghahn Books.

Tomšič, Matevz, and Mateja Rek. 2008. "Governance and Civil Society at the EU Level." Managing Global Transitions 6, no. 4: 403-20.

Trägårdh, Lars. 2007. "The 'Civil Society' Debate in Sweden: The Welfare State Challenged." In State and Civil Society in Northern Europe-The Swedish Model Reconsidered, edited by Lars Trägårdh, 9-36. New York, NY: Berghahn Books.

Trägårdh, Lars, Susanne Wallman-Lundåsen, Dag Wollebæk, and Lars Svedberg. 2013. Den svala svenska tilliten: förutsättningar och utmaningar. Stockholm, Sweden: SNS.

Trenz, Hans-Jörg. 2007. "A Transnational Space of Contention? Patterns of Europeanisation of Civil Society in Germany." In Governance and Civil Society in the European Union, edited by Carlo Ruzza and Vincent Della Sala, 89-112. Manchester, UK: Manchester University Press.

—. 2009. "European Civil Society: Between Participation, Representation and Discourse." Policy and Society 28, no. 1: 35-46.

Warleigh, Alex. 2001. "Europeanizing' Civil Society: NGOs as Agents of Political Socialization." Journal of Common Market Studies 39, no. 4: 619-39.

Wijkström, Filip, and Torbjörn Einarsson. 2006. Från nationalstat till näringsliv?: det civila samhällets organisationsliv $i$ förändring. Stockholm, Sweden: Ekonomiska Forskningsinstitutet.

Zippel, Kathrin. 2004. "Transnational Advocacy Networks and Policy Cycles in the European Union: The Case of Sexual Harassment." Social Politics: International Studies in Gender, State and Society 11, no. 1:57-85. 
SECTION I

This open access library edition is supported by the University of Lund. Not for resale. 
This open access library edition is supported by the University of Lund. Not for resale. 
Chapter 1

\title{
EUROPEANIZATION OF AND BY CIVIL SOCIETY TOWARD AN ANALYTICAL FraMEWORK
}

\author{
Kerstin Jacobsson and Håkan Johansson
}

Europeanization research has become an increasingly productive research field, focusing on how European Union (EU) integration and EU policy formation in various ways induce changes in the member states, and how they affect policy as well as politics and the polity (e.g., Falkner et al. 2005; Featherstone and Radaelli 2003; Graziano and Vink 2008; Olsen 2002; Risse, Green Cowles, and Caporaso 2001). To date there has been much more focus on the effects of EU integration and EU policy formation on state structures and public policies in the member states than on the Europeanization of civil society (for exceptions, see, e.g., Kendall 2010; Rek 2010; Ketola 2013; Sánchez-Salgado 2014; Karlberg and Jacobsson 2015; Kröger 2016). The limited research attention given to the role that civil society organizations (CSOs) might play in Europeanization processes is surprising given the increasing number of civil society actors operating at the EU level, the development of multilevel interactions between EU-level and national-level civil society actors, and the EU's interest in involving civil society to overcome its own legitimacy problems and limited mandate in certain policy fields (see Johansson and Kalm 2015; Kendall 2010; Ketola 2013; Sánchez-Salgado 2014). When civil society actors have been in focus, most of the attention has been on either the participation of civil society actors in EU-level governance arrangements (e.g., Jobert and Kohler-Koch 2008; Kröger 2016, 2018; Lindgren and Persson 2011) or on their participation in 
European umbrella structures (e.g., Johansson and Lee 2014; Kohler-Koch 2010a; Kröger 2018; Ruzza 201 1; Steffek and Hahn 2010; Steffek, Kissling, and Nanz 2008; Tomšič and Rek 2008).

This chapter aims to contribute to how we can understand the roles of civil society in Europeanization processes and above all how the EU offers both enabling and constraints for the scope for action of CSOs. The chapter proposes an analytical perspective that conceives of CSOs as both the subjects in and objects to Europeanization processes. It seeks to take a perspective that acknowledges how civil society actors can be engaged in using Europeanization processes for their own purposes aiming to shape the circumstances or the policies of relevance for them and their beneficiaries (subject position) and/or being subordinated to Europeanization processes, directly or indirectly accepting or adapting to requirements from the EU (object position). While other studies have focused on one or a few types of Europeanization and their relevance for CSOs (e.g., Johansson and Kalm 2015; Ketola 2013; Sánchez-Salgado 2014) we propose a more inclusive multidimensional approach to civil society Europeanization stressing regulatory, financial, and organizational Europeanization as well as participatory, discursive, and cultural Europeanization.

The chapter is structured as follows. First, we provide a brief overview of existing research on Europeanization generally, arguing for an analytical perspective that is sensitive to both top-down and bottom-up dynamics. Second, we outline our own analytical framework. Third, we relate our perspective to previous studies on the Europeanization of civil society, and, fourth, offer a brief conclusion.

\section{Perspectives on Europeanization}

While studies of European integration have existed for a long time and have paid attention to the formation of the EU as a common political, social, and economic project and governance structure, the ideas underpinning the term "Europeanization" are more concerned with if, how, and to what extent the EU matters for institutional changes at the national level as well as the mechanisms by which such influence operates. The Europeanization literature also pays attention to the domestic factors that mediate the influence from the EU, explaining why the impact of the EU differs across member states and domestic contexts. Moreover, different definitions of Europeanization hold different views of what exactly it is that is Europeanized. These issues are crosscutting in various theoretical perspectives on Europeanization. For the purposes of this chapter and our volume, we will shortly discuss three key approaches on Europeanization-top-down, interactive, and usage of 
Europe approaches-focusing especially on the conceptualization of agency within each.

Much debate on Europeanization has been conceptualized as top-down approaches. In the mid-1990s, for instance, Ladrech $(1994,69)$ defined Europeanization as "an incremental process re-orienting the direction and shape of politics to the degree that EU political and economic dynamics become part of the organizational logic of national politics and policy-making." A few years later, Börzel $(1999,574)$ approached Europeanization as "a process by which domestic policy areas become increasingly subject to European policy-making." These definitions emphasize Europeanization as the impact of the EU on national policies and institutions or the extent to which "the implementation of European policies implies adjustments in domestic institutions" (Knill and Lehmkuhl 1999; see also Knill and Lehmkuhl 2002). Definitions of this kind hence separate the European domain from the domestic level and stress aspects of downloading of European policies to domestic levels (Kallestrup 2005).

Also within top-down models there is an implicit actor dimension. On the one hand, Europeanization might affect how power is dispersed across the domestic political system. Europeanization "leads to a redistribution of power among a variety of domestic actors, from legislatures, courts, regional governments, to interest groups and companies" (Risse, Green Cowles, and Caporaso 2001, 11). On the other hand, Europeanization processes might also cause and be assisted by changes in domestic actors' ideas, interests, and self-identification (see also Börzel and Risse 2003). Risse, Green Cowles, and Caporaso $(2001,12)$ label this process as learning (see also Knill and Lehmkuhl 1999, 2002). In Börzel and Risse's (2003) vocabulary, such learning processes might be facilitated by norm entrepreneurs helping to diffuse European ideas and norms in the domestic context.

Scholars have also stressed more interactive perspectives (or processperspectives) on Europeanization because it cannot be reduced to what is happening in Brussels, but needs focus on the complex processes and actions that take place at the national, regional, and local levels (Radaelli and Pasquier 2008 , 36). Radaelli $(2003,34)$ argues, "European policy is not a mysterious deus ex machina situated 'up there,"' and that analyses of Europeanization must focus on the domestic level (e.g., conditions, structures and actors). Unlike the more formalistic top-down oriented approaches, this approach includes a wider array of aspects about what is Europeanized, including not only formal policies, but also belief systems, policy paradigms, and ways of doing things. Europeanization is in this respect defined as the processes of "construction, diffusion and institutionalization of formal and informal rules, procedures, policy paradigms, styles, ways of doing things and shared beliefs and norms, which are at first defined and consolidated in the making 
of EU decisions and then incorporated in the logic of domestic discourse, identities, political structures and public policies" (Radaelli 2000, 4). This also suggests a broader view on how processes of Europeanization might take place. Those processes might follow formal political channels and procedures as national actors implement decisions taken at the EU level, yet also follow from the diffusion, transfer, and translation of ideas and policies into a national context and vice versa. Analyses of Europeanization should thus not be restricted to national reform processes or changes in political institutions but include changes in discourses, identities, belief systems, actor constellations, power relationships, and so on.

A third approach to Europeanization further stresses the agency dimension to the Europeanization processes. Within this approach, the key question to be analyzed is the relevance of the EU for domestic actors, and how they make active use of the EU in the context of their domestic institutions, policies, and actor setups (Jacquot and Woll 2003; Kallestrup 2005; Sánchez-Salgado 2014; Woll and Jacquot 2010; for discussion on bottom-up approaches, see Bache and Jordan 2006; Jordan and Liefferink 2004). The stress on agency and the strategic element of actors is most notable in the "usage of Europe" approach. Woll and Jacquot argue that the EU "can become a vector of change by providing new resources, references and policy frames, which national policy actors use strategically. It therefore becomes crucial to understand what motivates these different strategies and to study the action of individual participants in the policy process" (Woll and Jacquot 2010, 113). This implies that domestic actors can (and want to) take a very active and strategic stance on EU policies in that they "engage with, interpret, appropriate or ignore the dynamics of European integration" (Woll and Jacquot 2010, 116). It arguably accentuates that a proper understanding of Europeanization cannot be limited to formal political processes, but emphasis rather lies on what domestic actors do with "Europe."

The strong emphasis on actors also paves the way for a closer analysis of the various resources embedded in Europeanization processes. The development of EU ideas, court cases, and policies carries different types of resources for domestic actors to try to exploit and make use of. The sets of resources analyzed within this approach often include legal resources (primary legislation, secondary legislation, case law, etc.), financial resources (budgetary constraints as well as new funding opportunities), cognitive and normative resources (communications, ideas, etc.), political resources (argumentation, participation in multilevel games, etc.), and institutional resources (access to committees, agencies, networks, etc.) (Woll and Jacquot 2010). As such it also has a strong resemblance to other theories stressing the EU as a political opportunity structure for civil society actors to act on, to try to push their 
agenda, mobilize resources, or engage in building collective action (e.g., Koopmans 1999).

However, domestic actors are in this respect not just passive transmitters or receivers of ideas and policies from one political level to another. They rather try to use EU resources to pursue their political agenda-in other words, to strengthen their own position against others' positions. Emphasizing the strategic element in this political game, the authors claim that such political actors might use the EU when it suits them and their agenda, while in other instances they might not refer to the EU at all (Graziano, Jacquot, and Palier 2011, 13-14).

\section{Toward a New Analytical Framework}

These three perspectives on Europeanization have their merits, but we suggest that a more elaborate framework is needed for the study of the constraining and enabling effects of Europeanization on CSOs and their scope for action. To understand civil society as shaped by, as well as participating in shaping, European policies, politics, and polities, including European identity-making, some elaborations are needed.

Top-down approaches are central and above all contribute to the analysis of how and why civil society becomes object to Europeanization processes but there is a tendency to downplay the agency dimension in analyses of Europeanization. The usage of Europe approach has key relevance for how we view civil society and Europeanization in this volume, above all with regard to our analytical interest in the role of actors in Europeanization processes. At the same time, the usage of Europe approach is heavily influenced by a strategic action framework that makes the assumption of rational actors using European resources to forward their domestic interests and to achieve their ends. Rather than assuming fixed interests to be pursued through the strategic use of European resources, analysis into Europeanization and CSOs would benefit from exploring the links between interests, ideas, and identities to capture how these are negotiated and changed in processes of Europeanization. While CSOs can be conceived as rational actors involved in political game-playing or strategic agents using new opportunities, the EU and Europeanization processes offer both opportunities and constraints. Considering such a duality of Europeanization further stresses how studies of CSOs need to recognize their social positions in relation to Europeanization processes, expressing aspects of constrained and embedded agency (see Johansson and Kalm 2015). Such an institutionalist view on Europeanization suggests that CSOs can hold different roles or positions in Europeanization processes-both as subjects in or objects to Europeanization 
processes. The former suggests a status of being actively engaged or even having the potential to shape and influence outcomes, while the latter suggests a status of being the addressee or subordinate to such processes (see Streeck and Thelen 2005). Several chapters in this volume elaborate on the complex relationship of being engaged in, as well as forced to adjust and adapt to, Europe.

The perspectives discussed above moreover tend to be overly focused on public policies, formal political and policymaking processes, and public actors. This is particularly evident in top-down approaches. We argue for a more comprehensive view of the multiple ways in which CSOs can engage in and/or be affected by Europeanization processes, sometimes related to formal policymaking but certainly not limited to it. Expanding on Radaelli's view on Europeanization as including both formal policies and belief systems, as well as the multiple types of resources identified within the usage of Europe approach, we argue that studies of civil society and Europeanization would benefit from taking a broader view on dimensions and types of Europeanization. Taking stock of other studies (see, e.g., Johansson and Kalm 2015; Sánchez-Salgado 2014) Europeanization takes place through the diffusion of formal regulation and binding rules, ideas, and discourses, but also through financial transfer and the spread of organizational models. Considering the mediating role of CSOs, Europeanization also includes the development of networks, alliances, and social partnerships across levels and new arenas for participation, or even the construction of a public sphere that potentially crosses political levels.

Studies of Europeanization and civil society can certainly benefit from an interactive approach to Europeanization. Many of the chapters in this volume follow at least in a broad sense Radaelli and Exadaktylos's (2010, 193) definition of Europeanization as "an interactive process, rather than a simple process of unidirectional reaction to 'Europe.' It covers both the notion of Europeanization as 'domestic impact of Europe' (or pressure) and Europeanization as creative usages of Europe." Such an approach is highly valuable considering that apart from posing rules for domestic policymakers as well as domestic CSOs, the EU allows for processes of constant interactions between CSOs (and other actors), horizontally as well as vertically (e.g., Holzhacher 2007; Kendall 2010; Mau and Mewes 2012). They engage in multilevel games, moving between levels and going back and forth between the EU and national levels with their demands. Such movement between political levels is sometimes framed in terms of a boomerang effect (Keck and Sikkink 1998) or a ping-pong effect (Zippel 2004). It might include participation in EU lobbying processes and the creation of EU umbrella organizations, or might also involve transnational networking and cooperation and the exchange of experiences and learning from CSOs in other countries. 
Taking stock of these arguments, we propose a typology for the study of Europeanization of and by organized civil society. We consider the typology as a heuristic device for the studies of civil society and Europeanization. Following from previous arguments, we identify six types of Europeanization-see further discussions below-and for each we identify the mechanisms at play, which are understood as the mechanisms by which potential influence takes place and thus change is brought about (cf. Knill and Lehmkuhl 1999). In naming these mechanisms, we use the term "transfer" to account for such mechanisms of influence, remaining aware that such influence can go in different directions (vertically from the domestic setting to the European or vice versa, as well as in horizontal directions). We stress that transfer here does not necessarily mean the wholesale transference of rules, norms, models, and so on, but also entails processes of active use and translation during the transfer process (cf. Czarniawska and Sevón 1996) depending on the subtype at hand. Considering Europeanization in this manner also stresses that there are enabling as well as constraining elements involved. Linked to each of the different types of Europeanization, we furthermore identify different positions or roles that CSOs are assigned or play, accounting for their roles as subjects in and objects to Europeanization processes and linked to the enabling and constraining factors of various Europeanization processes. The typology is analytical and parsimonious, while in real life types, mechanisms, and roles are intertwined and most likely mutually reinforcing.

\section{Types of Europeanization in Previous Research}

To further explore this typology, in the following we draw on previous research on civil society and Europeanization in order to address the different types of Europeanization as well as how roles of being subjects and objects have been identified.

\section{Regulatory Europeanization}

One of the distinctive features of the EU is its nature as a legal entity, thus it is not surprising that regulatory Europeanization stands out as one of the most important ways in which Europe impacts on conditions in the member states, including civil societies. Regulatory Europeanization thus shapes the legal environment in which CSOs operate; the mechanism at play here is the transfer of, and thus the pressure of, legal norms on civil society. This pressure may be exerted either through the formal pressure of binding 


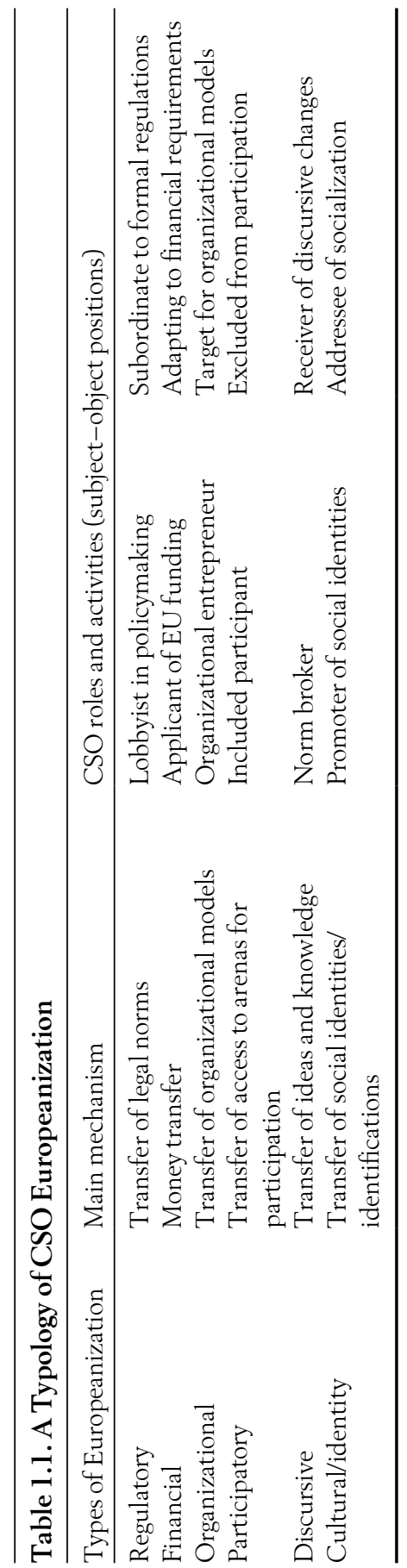

This open access library edition is supported by the University of Lund. Not for resale. 
regulations or through the soft pressure of guidelines, codes of conduct, and soft laws (see e.g., Jacobsson 2004a, 2004b), all of which have direct and/ or indirect relevance for CSOs. Civil society might thus be the direct object of regulation, the adaptational pressure of which will depend on existing national structures and civil society models. The EC VAT Directive, for instance, puts pressure on national policies and CSOs because it requires governments to treat nonprofit and for-profit organizations in the same way (see introduction). Member states that, by tradition, have exempted nonprofit organizations from paying VAT are thus directly in conflict with the EU in this regard.

Transfer of legal norms might empower CSOs differently, affecting their centrality or marginality in national policymaking processes. CSOs can also be indirectly affected by regulation in other areas, such as economic integration and internal markets that reshape the domestic opportunity structures in which the CSOs operate. CSOs can be subjects in these processes-for example, in terms of being engaged in lobbying to influence the formulation of these models, norms, and regulations (see, e.g., chapter 10). In some national contexts, the regulatory ambitions of the EU can pose a threat or provide an opportunity because they challenge existing domestic policies, practices, and positions. Because CSOs may not have the same aims and priorities, it is evident that regulatory Europeanization might have different meanings and consequences for different segments of domestic civil society.

\section{Financial Europeanization}

Financial Europeanization takes place through the transfer of money from the EU to CSOs. Such financial transfers can be distributed directly by EU institutions to CSOs to fulfill certain tasks under particular budget lines. They might be distributed through agencies in member states, as in the case of the structural funds, and might affect the opportunity structures for CSOs in different ways. The financial dependency of CSOs operating in Brussels is well known because they tend to receive a large share of their resources from the European Commission (EC), raising concerns about their independence and their willingness to criticize the hand that feeds them (e.g., Johansson and Lee 2015). Financial Europeanization thus includes EU funding to national, regional, and local CSOs (Mahoney and Beckstrand 2011; Sánchez-Salgado 2014), the impact of which might differ in different contexts. In countries where domestic funding sources are sparse, support from EU sources might be a highly valuable and substantial part of domestic CSOs' budgets. What has emerged is thus a complex multilevel financial infrastructure for domestic CSOs to adopt, adapt, and act on. 
Money transfer might have several outcomes on the part of CSOs considering their status as subjects in and objects to Europeanization processes. Classic subject positions of course include being engaged in seeking (and gaining EU) funding, yet the object positions could include more-complex aspects of how financial Europeanization pushes organizations in certain directions. For instance, Sánchez-Salgado (2014) notices that financial Europeanization has promoted changes in domestic organizations' working procedures (e.g., in terms of professionalization, internal structures, and working orders) and might channel CSOs' engagement in specific directions and lead to goal displacement (reflecting our previous argument on overlap between types of Europeanization). Similar effects might also be indirect as domestic CSOs seek to build administrative and professional capacities just to be able to compete for and gain EU funding and as a way to respond to certain management techniques and evaluation criteria. At the same time, to receive funding from particular sources, such as the EU, might give particular recognition and status, or it might have the opposite effect and make one a target of criticism from the public or peer CSOs due to the acceptance of certain norms and values. Another effect of EU funding has been found to be a differentiation between haves and have-nots in domestic civil society where large organizations or organizations belonging to umbrella organizations often have the administrative capacity to apply for funding while smaller organizations do not (e.g., Rek 2010; Roth 2007). This in turn might lead to differential empowerment in the domestic context.

As mentioned above, the significance of financial Europeanization differs due to national conditions and structures. European funding has been found to enable the growth of professional and effective advocacy organizations in the region of Central and Eastern Europe (Císar and Vráblíková 2010). Others have assessed the development more negatively and have shown that EU support has fostered short-term project orientation among CSOs and has benefitted mainly the wealthier organizations with high administrative capacity at the expense of smaller organizations, and this has sometimes resulted in professionalized organizations being decoupled from their grassroots support or the local population (e.g., Rek 2010). Funding requirements might force informal groups to formalize, as in the case of the community organizations in Lithuania studied by Aidukaite and Jacobsson (2015), where in some cases local activists were talked into forming community organizations by local authorities in order to access EU funds for renovations or the development of local infrastructure.

The outcomes of financial Europeanization are thus complex because it can have spillover effects on domestic CSOs' advocacy functions and empowerment and can influence to what extent they might be willing to bite the hand that feeds them. While this might be a more straightforward 
relation between a state and domestic CSOs, the multilevel style of financial Europeanization implies greater complexity. For instance, financial Europeanization might foster and promote the independence and advocacy function of domestic CSOs vis-á-vis national public agencies and authorities but might also imply new interdependencies between CSOs and domestic authorities. Thus, the outcome of financial Europeanization might be new forms of co-optation or goal displacement, indirectly creating new power balances among domestic actors. How EU funding might affect organizational identities and strategies is analyzed in chapter 6 .

\section{Organizational Europeanization}

Organizational Europeanization takes place through the transfer of organizational models, including transparency requirements and other management techniques, which induce processes of formalization and professionalization of domestic CSOs. This type of Europeanization is interactive because top-down and bottom-up processes tend to be enmeshed. The EC has actively encouraged domestic CSOs to mobilize at the EU level or to be directly engaged in setting up European peak associations (Johansson and Kalm 2015). An even stronger element of pushing domestic CSOs in a certain direction can be found with regard to the widespread use of partnership models between public authorities and CSOs (or umbrella organizations) (e.g., Aidukaite and Jacobsson 2015; Císař and Vráblíková 2010; Karlberg and Jacobsson 2015). The promotion of partnership models through the European Social Fund (ESF) is a pertinent example of the transfer of models across levels, and thus an example of expectations-or direct pressure-to change domestic working procedures to conform to EU standards.

Many large international CSOs tend to maintain an office in Brussels, and national CSOs have formed umbrella networks and pooled resources in order to maintain a daily presence there. What has emerged is thus a complex multileveled structure of associational relations between EU umbrella networks and domestic CSOs (national, regional, and local). Such a multilevel associational structure might have effects on domestic civil society, potentially changing internal power structures as well as creating new types of hierarchies, actor constellations, and forms of exclusion and segmentation. The transfer of organizational models also takes place through horizontal Europeanization processes between and within civil society itself, and the growth of and coordination among CSOs across borders is a pertinent feature of the European integration process.

Whereas some domestic actors might gain positions that allow them to engage in either the vertical or the horizontal style of organizational 
Europeanization, others might be excluded (partly because they do not have the resources needed to be present in such networks or umbrella structures). The expectations to form coordination among domestic actors, such as the setting up of national or local umbrella structures, might thus promote new alliances, but also might promote disputes, tensions, and conflicts regarding aims and causes for one's operations, as has been found in studies of domestic women's movements (see chapter 8 and 9; Strid 2009; Karlberg and Jacobsson 2015). The setting up of national and/or local umbrella structures might help CSOs gain leverage in relation to domestic policymakers, such as in the case of community organizations in Lithuania where the formation of such structures has enabled dialogue and cooperation with, as well as provided new funding opportunities by, local and national authorities (Aidukaite and Jacobsson 2015). We thus find a number of roles and positions for CSOs in organizational Europeanization such as members and organizational entrepreneurs.

\section{Participatory Europeanization}

Participatory Europeanization follows from the establishment of new arenas. Such arenas might be closely linked to various EU institutions or to political processes and decision-making taking place at the EU and domestic levels. Here we might include participation in high-profile arenas such as the European Citizens' Initiative (ECI; e.g., Hedling and Meeuwisse 2015) and open consultation practices developed by the EC (2015). Other arenas for participation are much more disentangled from the EU and are set up in response to or even in direct opposition to the EU, such as the European social forums (e.g., della Porta and Caiani 2011). To some extent these participatory arenas can be linked to the organizational structure that EU-based umbrella peak CSOs offer for domestic organizations.

The significance of these arenas for civil society actors differs depending on their spread, accessibility, and degree of inclusiveness. EU peak associations might act as mediators as they collect, analyze, and package domestic concerns and transfer such information to EU institutions (e.g., KohlerKoch 2010a; Steffek, Kissling, and Nanz 2008; Steffek and Hahn 2010; Tomšič and Reik 2008 ). Kohler-Koch (2010b) found that much of the participation at the EU level tends to be exclusive and based on forms of elite participation because few (domestic) CSOs are engaged, and those that are participating tend to have limited grassroots connections (see also Hahn and Steffek 2011; Kohler-Koch 2012; chapter 8).

Participatory Europeanization also gives rise to complex processes of how CSOs need to subordinate to participatory demands. This may entail facing 
extensive barriers when engaging in Europeanized arenas, such as language, knowledge, and financial barriers. It might also be due to limited time and interest among peers for the relevance of Europe to their domestic activities and agendas (Rodekamp 2014). Previous studies also indicate weak chains of representation when domestic actors engage in European arenas. Studies find that only a few domestic actors are invited to participate and included in European arenas. This implies processes of disempowering on parts of actors who are not included or lack sufficient resources to participate (e.g., Johansson and Lee 2014; Kröger 2016).

\section{Discursive Europeanization}

Discursive Europeanization occurs primarily through the transfer of ideas, including knowledge; this transfer operates at the level of thinking about policy, politics, or polities (Jacobsson 2004a). Discursive Europeanization includes specific ways of defining and framing problems (Knill and Lehmkuhl 1999), the establishment of distinct policy paradigms, or, through the production of discourse ("Euro-discourse" as Jacobsson 2004a puts it), the establishment of a common language and a set of statements based on a specific problem understanding, thus privileging some problem understandings while excluding others. Engaging in common discourses might also lead to shared sensitivity to common problems, providing new focal points for attention and thus affecting the agenda orientation of CSOs (Kendall 2010). Discursive Europeanization at times takes place in or via other types of Europeanization, for instance regulatory and/or participatory, but is kept separate in the following discussion.

CSOs are influenced by European discourses (either by consciously or unconsciously adopting them or having to relate to them) while also defending and putting forward and uploading their own alternative understandings at times, thus being both subjects in and objects to this discursive battle. Discursive Europeanization offers CSOs opportunities to act as norm entrepreneurs, or change agents helping to diffuse European ideas into the domestic context and to mobilize domestic actors in support of these ideas and norms (cf. Börzel and Risse 2003), or, alternatively, they might be engaged in communicating and mobilizing norms and ideas upward to the EU level. However, CSOs can also actively resist, refuse, and counteract European ideas and norms and thus they function as gatekeepers, as discussed by Karlberg and Jacobsson (2015) in their study of the Swedish Women's Lobby (SWL), which actively resisted and refused to circulate some policy ideas coming from the European Women's Lobby (EWL). At the opposite end of the spectrum, CSOs can certainly also be objects to 
discursive Europeanization and subordinate to discursive changes directly or indirectly affecting them and their institutional environment.

Apart from Europeanization in the form of ideas and discourses, we also include in discursive Europeanization the building of a common knowledge base at the European level and the systematic production, diffusion, and sometimes standardization of knowledge (such as common statistics or indicators) (Jacobsson 2004a). Such standardization of knowledge or policy-thinking is often implemented and reinforced by between-country comparisons of performances, benchmarking and the identification of best practices, and peer review processes. Indeed, discourses tend to become operational through such mechanisms. CSOs might be actively engaged in these processes, once again recognizing that such forms of Europeanization might affect them differently.

Recognizing Europeanization as an interactive process implies that CSOs also can function as brokers (mediators) of knowledge and ideas at different levels or between different spheres of society (see Sahlin-Andersson 1996 on the editing of knowledge; also Mörth 2003). As stressed by Czarniawska and Sevón (1996), transnational knowledge is seldom diffused wholesale, but instead is actively interpreted and thus translated into domestic contexts. Such discourses tend to be interpreted differently in different contexts with different policy traditions and institutions, and where civil society actors are engaged in giving concrete meaning and substance to EU discourse. In any case, $\mathrm{CSO}$ s are affected by being assigned specific roles and expectations that they can resist, adapt to, or embrace. One example is how the discourses on social economy and social enterprises are diffused and translated in a specific national context, challenging national discourses and subject positions for domestic CSOs and illustrating how discursive Europeanization might constitute a shift in policy thinking or problem formulation nationally (see chapter 7).

\section{Identity Europeanization}

Identity Europeanization occurs in and through the transfer of identities and forms of identification as well as through the social interactions that take place as individuals meet and participate in, or experience, European or transnational processes, all of which affect the identification and selfunderstanding of the actors (cf. Börzel and Risse 2003; Beyers 2005). Thus, social interaction can lead to changes in social identity, such as gradual changes in outlooks and behaviors following the logic of appropriateness in these transnational arenas (cf. March and Olsen 1989). Epistemic communities and advocacy networks-of which CSOs can be part-are held together 
by common knowledge claims as well as by shared beliefs and values (Börzel and Risse 2003, 67), and participation in such networks readily implies norm internalization and thus resocialization. CSOs can also act as brokers and translators of social identities, thus they can act as norm entrepreneurs mediating between the supranational and domestic identities and self-understandings.

Identity change can go in both directions, and existing identities can be reinforced by exposure to European or other (trans) national ideas and identities. For instance, Bengt Jacobsson (2000) has claimed that participation in European arenas and transnational political processes tends to reinforce the national outlook of actors. They are forced or experience a need to develop their national positions and standpoints, thus re-creating national actors. While Jacobsson's focus was on government actors, the same might be true for CSOs. Karlberg and Jacobsson (2015), for instance, found that participation in the EWL means that Swedish women's organizations are expected to develop and communicate national positions to the EWL, sometimes revealing clashes with the dominant problem and self-understandings of the Swedish member organizations and those of the EWL or women's organizations of other member states. And these clashes might reinforce rather than challenge existing norms and identities.

Accordingly, CSOs can function as agents of political socialization, but their willingness and capacity to do so might differ considerably (Warleigh 2001). They might also be the object of such political socialization processes because other actors try to impose particular identities on them. Whether they instrumentally adapt to, unconsciously adopt, or actively resist identities assigned by EU discourses are empirical questions, explored, for instance, by Scaramuzzino and Scaramuzzino in chapter 9 .

\section{Concluding Discussion}

The analytical framework developed in this chapter seeks to pave the way for a more comprehensive understanding of how the EU and Europeanization processes might affect CSOs and how CSOs might engage in such processes. The framework is developed in response to current debates on Europeanization and aims to go beyond the state of the art by explicitly exploring CSOs as subjects in and objects to Europeanization processes, particularly emphasizing the interactive, multidimensional, and embedded agency elements of Europeanization. The interactive element refers to an understanding of Europeanization as a process of constant interactions between different sets of actors, horizontally as well as vertically. The multidimensional aspects refer to the variety of ways in which Europeanization 
takes place, as illustrated in our six types of Europeanization. This typology opens for theorization of how different types and mechanisms of Europeanization interact and support-or contradict-each other in real-life processes of Europeanization. The embedded agency element refers to an understanding of CSO agency as bounded and constrained due to CSOs' embeddedness in social relationships, social structures, and political cultures. Interests and identities are shaped by the context in which CSOs operate but are also renegotiated and reshaped during the course of multilevel and horizontal transnational interactions.

Our discussion hence elaborates a more complete list of roles potentially played by CSOs as they become engaged in, or choose to be involved in, European processes compared to the types of roles and subject positions found in the existing Europeanization literature. The discussion furthermore suggests that subject and object positions should not be considered as separate; instead, these positions can also be entangled in complex ways because CSOs might be both engaged in seeking to change the rule of the game, for instance though intensive lobbying activities, as well as being the object of such regulations. Similarly, CSOs might be engaged in using the opportunities of financial Europeanization, applying and receiving EU funding, yet such activities might also force other considerations and activities-for instance, compliance with EU regulations, and potentially the change of organizational routines and models.

Moreover, while the most prominent roles certainly include subject and object positions, our review also suggests that there is a position somewhat in between, illustrating that CSOs can act as a form of a mediator in Europeanization processes. Such a mediating role might include CSOs acting as a translator or transmitters of ideas and models or engaging in cofunding or coregulating practices.

The framework also opens the way for the analysis of the outcomes and processes that such different types of Europeanization might give rise to, for instance in terms of changing positions, relations, and statuses of civil society actors at the national and EU levels. This implies as well that our argument goes beyond much of the current debate on Europeanization that mainly focuses on formal political actors (or business actors). The analytical framework also has significance for civil society studies generally because it recognizes that the EU is not something that is located separate from the countries themselves that can be separated from investigations of civil society, its forms, and its actors at the national level.

Finally, implicit in these debates lies the broader question of whether Europeanization will lead to the assemblage and interaction of national civil society models in a multilevel structure or the formation of a common European civil society. Delanty and Rumford (2005) suggest that the 
difference lies between thin and thick forms of Europeanization. European integration involves and therefore carries implications for not only the legal and political spheres, but also the social and cultural spheres; that is why theories on Europeanization need to accommodate the consequences of European integration along multiple dimensions. Indeed, it is typically through what we have discussed as participatory, discursive, and identity mechanisms that the thick form of Europeanization as social transformation can be achieved, while regulatory, financial, and organizational mechanisms can be better interpreted as the building blocks of a multilayered European civil society. The different chapters in this volume provide some insights into these processes, engaging with empirical investigations of different types of Europeanization and different subject positions ascribed and taken, as well as the processes and outcomes such involvement might result in. These investigations moreover illustrate the significance of certain types of Europeanization for particular sets of actors as well as the overlap and interconnectedness between different types of Europeanization.

Kerstin Jacobsson is Pofessor of Sociology at the University of Gothenburg, Sweden. Recent publications include Animal Rights Activism: A MoralSociological Perspective on Social Movements (coauthored with Jonas Lindblom, University of Chicago Press, 2016) and Civil Society Revisited: Lessons from Poland (coedited with Elzbieta Korolczuk, Berghahn Books, 2017).

Håkan Johansson is Professor of Social Work at the School of Social Work, Lund University, Sweden. His research interests include civil society, the EU, advocacy, social policy, poverty, and elites. He is currently leading a research program on civil society elites in Europe (funded by the Swedish Foundation for Humanities and Social Sciences) and recently published a book titled EU Civil Society: Patterns of Cooperation, Competition and Conflict (coedited with Sara Kalm, Palgrave, 2015).

\section{References}

Aidukaite, Jolanta, and Kerstin Jacobsson. 2015. "Europeanization and Urban Movements: Political Opportunities of Community Organizations in Lithuania." In Urban Grassroots Movements in Central and Eastern Europe, edited by Kerstin Jacobsson, 247-72. Farnham, UK, Surrey Ashgate.

Bache, Iain, and Andrew Jordan, eds. 2006. The Europeanization of British Politics. Basingstoke, UK: Palgrave Macmillan.

Beyers, Jan. 2005. "Multiple Embeddedness and Socialisation in Europe: The Case of the Council Officials." International Organisation 59, no. 4: 899-936. 
Börzel, Tanja. 1999. "Towards Convergence in Europe? Institutional Adaptation to Europeanization in Germany and Spain." Journal of Common Market Studies 37, no. 4: 537-96.

Börzel, Tanja, and Thomas Risse. 2003. "Conceptualizing the Domestic Impact of Europe." In Featherstone and Radaelli, The Politics of Europeanization, 57-80.

Císař, Ondřej, and Katheřina Vráblíková. 2010. "The Europeanisation of Social Movements in the Czech Republic: The EU and Local Women's Groups." Communist and Post-Communist Studies 43: 209-19.

Czarniawska, Barbara, and Guje Sevón. 1996. Translating Organizational Change. Berlin, Germany: de Gruyter.

Delanty, Gerard, and Chris Rumford. 2005. Rethinking Europe. Social Theory and the Implications of Europeanization. London, UK: Routledge.

della Porta, Donatella, and Manuela Caiani. 201 1. Social Movements and Europeanization. Oxford, UK: Oxford University Press.

European Commission (EC). 2015. "Better Regulation Guidelines." COM (2015) 215 final, September 5. Brussels, Belgium: European Commission.

Falkner, Gerda, Oliver Treib, Miriam Hartlapp, and Simone Leiber. 2005. Complying with Europe. EU Harmonisation and Soft Law in the Member States. Cambridge, UK: Cambridge University Press.

Featherstone, Kevin, and Claudio Radaelli, eds. 2003. The Politics of Europeanization. Oxford, UK: Oxford University Press.

Graziano, Paolo, Sophie Jacquot, and Bruno Palier. 201 1. "Domestic Reconciliation policies and the usages of Europe." European Journal of Social Security 13, no. 1: 3-25.

Graziano, Paolo, and Maarten Vink, eds. 2008. Europeanization. New Research Agendas. Basingstoke, UK: Palgrave Macmillan.

Hahn, Kristina, and Jens Steffek. 2011. "Transmission Belts or Satellites? How Transnational CSOs Interact with Their Constituents." European Consortium for Political Research Conference, Reykjavik, Iceland.

Hedling, Elsa, and Anna Meeuwisse. 2015. "The European Citizens' Initiative Stage: A Snapshot of the Cast and Their Acts" In Johansson and Kalm, EU Civil Society, 210-28.

Holzhacher, Ronald. 2007. "The Europeanization and Transnationalization of Civil Society Organizations Striving for Equality: Goals and Strategies of Gay and Lesbian Groups in Italy and the Netherlands." Working Paper 2007/36. San Domenico di Fiesole, Italy: European University Institute.

Jacobsson, Bengt. 2000. Världen i staten. Europeisering, politik och statens organisation. Scores rapportserie 2000: 11 . Stockholm, Sweden: Stockholm University.

Jacobsson, Kerstin. 2004a. "Soft regulation and the subtle transformation of states: the case of EU employment policy." Journal of European Social Policy 14, no. 4: 355-70.

- 2004b. "Between Deliberation and Discipline: Soft Governance in EU Employment Policy.” In Soft Law in Governance and Regulation: An Interdisciplinary Analysis, edited by Ulrika Mörth, 81-101. Cheltenham, UK: Edward Elgar.

Jacquot, Sophie, and Cornelia Woll. 2003. "Usage of European IntegrationEuropeanization from a Sociological Perspective." European Integration Online Papers 7, no. 12.

Jobert, Bruno, and Beate Kohler-Koch, eds. 2008. Changing Images of Civil Society. From Protest to Governance. London, UK: Routledge. 
Johansson, Håkan, and Sara. Kalm, eds. 2015. EU Civil Society. Patterns of Cooperation, Competition and Conflict. Basingstoke, UK: Palgrave Macmillan.

Johansson, Håkan, and Jayeon Lee. 2014. "Bridging the Gap: How do EU-Based Civil Society Organizations Acquire Their Internal Representation?" VOLUNTAS: International Journal of Voluntary and Nonprofit Organizations 25: 405-24.

_. 2015. "Competing Capital Logics in the Field of EU level CSOs." In Johansson and Kalm, EU Civil Society, 61-80.

Jordan, Andrew, and Duncan Liefferink. 2004. "The Europeanization of National Environmental Policy." In Environmental Policy in Europe: The Europeanization of National Environmental Policy, edited by Jordan and Liefferink, 1-14. New York, NY: Routledge.

Kallestrup, Morten. 2005. Europeiseringen av nationalstaten. EU's konsekvenser for dansk reguleringspolitik of de nationale aktörers undervurderede rolle. Köpenhamn, Denmark: Jurist-och Ökonomfornundets forlag.

Karlberg, Eva, and Kerstin Jacobsson. 2015. "A Meta-organizational Perspective on the Europeanization of Civil Society: The Case of the Swedish Women's Lobby." VOLUNTAS: International Journal of Voluntary and Nonprofit Organizations 26, no. 4: $1438-59$.

Keck, Margaret, and Kathryn Sikkink. 1998. Activists Beyond Borders: Advocacy Networks in International Politics. Ithaca, NY: Cornell University Press.

Kendall, Jeremy. 2010. "The Limits and Possibilities of Third Sector Europeanisation.” Journal of Civil Society 6, no. 1: 39-65.

Ketola, Markus. 2013. Europeanization and Civil Society: Turkish NGOs as Instruments of Change? Basingstoke, UK: Palgrave Macmillan.

Knill, Christoph, and Dirk Lehmkuhl. 1999. "How Europe Matters. Different Mechanisms of Europeanization." European Integration Online Papers 3, no. 7.

—. 2002. "The National Impact of European Union Regulatory Policy. Three Europeanization Mechanisms." Journal of European Political Research 41, no. 2: 255-80.

Kohler-Koch, Beate. 2010a. "Civil Society and EU Democracy: 'Astroturf' Representation?” Journal of European Public Policy 17, no. 1: 100-16.

—. 2010b. "How to Put Matters Right? Assessing the Role of Civil Society in EU Accountability." West European Politics 33, no. 5: 1117-41.

—. 2012. "Post-Maastricht Civil Society and Participatory Democracy." Journal of European Integration 34, no. 7: 809-24.

Koopmans, Ruud. 1999. "Political. Opportunity. Structure. Some Splitting to Balance the Lumping." Sociological Forum 14, no. 1: 93-105.

Kröger, Sandra. 2016. Europeanised or European? Representation by Civil Society Organisations in EU Policy-Making. Colchester, UK: ECPR Press.

— 2018. "Strategic or Principled? The Engagement of Civil Society Organisations with the EU." Journal of Civil Society, 14: 41-57.

Ladrech, Robert. 1994. "Europeanization of Domestic Politics and Institutions: The Case of France." Journal of Common Market Studies 21, no. 1: 69-88.

Lindgren, Karl-Oskar, and Thomas Persson. 2011. Participatory Governance in the EU: Enhancing or Endangering Democracy and Efficiency? London, UK: Palgrave Macmillan.

Mahoney, Christine, and Michael, J. Beckstrand. 2011. "Following the Money: European Union Funding of Civil Society Organizations.” Journal of Common Market Studies 49 , no. 6. 1339-1361. 
March, James G., and Johan P. Olsen. 1989. Rediscovering Institutions. New York, NY: Free Press.

Mau, Steffen, and Jan Mewes. 2012. "Horizontal Europeanization in Contextual Perspective. What Drives Cross Border Activities within the European Union." European Societies 14, no. 1:7-34.

Mörth, Ulrika. 2003. "Europeanization as Interpretation, Translation and Editing of Public Policies." In Featherstone and Radaelli, The Politics of Europeanization, $159-78$.

Olsen, Johan. P. 2002. "The Many Faces of Europeanization.” Journal of Common Market Studies 40, no. 5: 921-52.

Radaelli, Claudio. 2000. "Whither Europeanization? Concept Stretching and Substantive Change." European Integration Online Papers 4, no. 8.

- 2003. "The Europeanization of Public Policy." In Featherstone and Radaelli, The Politics of Europeanization, 27-56.

Radaelli, Claudio, and Theofanis Exadaktylos. 2010. "New Directions in Europeanization Research." In Research Agendas in EU Studies. Stalking the Elephant, edited by Michelle Egan, Neill Nugent, and William Paterson, 189-215. Basingstoke, UK: Palgrave Macmillan.

Radaelli, Claudio, and Romain Pasquier. 2008. “Conceptual Issues.” In Europeanization. New Research Agendas, edited by Paolo Graziano and Maarten Vink, 35-45. Basingstoke, UK: Palgrave Macmillan.

Rek, Mateja. 2010. "Europeanization of Civil Society Sector in Central and Eastern Europe." Innovative Issues and Approaches in Social Sciences 3, no. 1: 160-86.

Risse, Thomas, Maria Green Cowles, and James Caporaso. 2001. "Europeanization and Domestic Change: Introduction." In Transforming Europe, Europeanization and Domestic Change, edited by Maria Green Cowles, James Caporaso, and Thomas Risse, 1-20. Ithaca, NY: Cornell University Press.

Rodekamp, Meike. 2014. Their Members' Voice. Civil Society Organisations in the European Union. Cologne, Germany: Springer Verlag.

Roth, Silke. 2007. "Sisterhood and Solidarity? Women's Organizations in the Expanded European Union." Social Politics: International Studies in Gender, State and Society 14, no. 4: 460-87.

Ruzza, Carlo. 2011. "Social Movements and the European Interest Intermediation of Public Interest Groups.” Journal of European Integration 33, no. 4: 453-69.

Sahlin-Andersson, Kerstin. 1996. "Imitating by Editing Success. The Construction of Organizational Fields and Identities.” In Czarniawska and Sevón, 69-72.

Sánchez Salgado, Rosa. 2014. Europeanizing Civil Society: How the EU Shapes Civil Society Organizations. Basingstoke, UK: Palgrave Macmillan.

Steffek, Jens, and Kristina Hahn, eds. 2010. Evaluating Transnational NGOs: Legitimacy, Accountability, Representation. Basingstoke, UK: Palgrave Macmillan.

Steffek, Jens, Claudia Kissling, and Patrizia Nanz. 2008. Civil Society Participation in European and Global Governance: A Cure for the Democratic Deficit? Basingstoke, UK: Palgrave Macmillan.

Streeck, Wolfgang, and Kathleen Thelen, eds. 2005. Beyond Continuity. Institutional Change in Advanced Political Economies. Oxford, UK: Oxford University Press.

Strid, Sofia. 2009. "Gendered Interests in the European Union-The European Women's Lobby and the Organization and Representation of Women's Interests." $\mathrm{PhD}$ diss., Örebro, Sweden: Örebro University. 
Tomšič, Matevz, and Mateja Rek. 2008. "Governance and Civil Society at the EU Level.” Managing Global Transitions 4: 403-20.

Warleigh, Alex. 2001. "Europeanizing' Civil Society: NGOs as Agents of Political Socialization." Journal of Common Market Studies 39, no. 4: 619-39.

Woll, Cornelia, and Sophie Jacquot. 2010. "Using Europe: Strategic Action in Multilevel Politics." Comparative European Politics 8, no. 1: 110-11.

Zippel, Kathrin. 2004. "Transnational Advocacy Networks and Policy Cycles in the European Union: The Case of Sexual Harassment." Social Politics: International Studies in Gender, State \& Society. 11 , no. 1: 57-85. 
Chapter 2

\title{
The Dual Role of European Union Civil SOCIETY ORGANIZATIONS BETWEEN EUROPEAN UNION INSTITUTIONS AND DOMESTIC Civil SOCIETIES
}

\author{
Håkan Johansson and Sara Kalm
}

\section{Introduction}

The European Union (EU) has in the past couple of decades developed a variety of means for interacting with organized civil society across Europe. It has incentivized the formation of Brussels-based umbrella organizations and networks that work in different issue areas and are expected to represent wider civil society in consultations with European institutions. These organizations have often been brought into existence by the provision of financial support and institutional access to European institutions. In addition to providing expertise and knowledge about local conditions, the involvement of these "EU-level civil society organizations (CSOs)" in consultations is expected to mediate-or even overcome-the distance between the EU's institutions and domestic civil societies by "bring [ing] Europe much closer to the people" (EC 2000, 4), thereby alleviating the criticism toward the EU for being an elitist project (Kohler-Koch and Rittberger 2007; Warleigh 2001). The expectation on part of the EU is that organized civil society can enhance the popular legitimacy of the EU by communicating Europe to national societies and citizens (Monaghan 2012). This has resulted in expanded-or at least altered-political opportunity structures for EU-level CSOs, acting in-between Brussels and national civil societies. 
This chapter investigates the roles EU-level CSOs play in the processes of Europeanization in terms of building links and connections with EU institutions as well as domestic CSOs. Our approach differs from the the vast mainstream literature on Europeanization, which mainly has addressed how EU institutions through formal political channels affect national political agendas and reform processes and patterns of policy change (for exceptions, see Ketola 2013; Sánchez-Salgado 2014). In line with the other contributions to this volume, we emphasize that civil society actors take an active and important part in Europeanization processes. We adopt the analytical framework developed in chapter 1 in this volume in order to structure the activities of EU-level CSOs when they act in the roles of objects to, subjects in, and mediators of Europeanization. Our aim is to provide a systematic account of the different roles that EU-level CSOs may and do take on, and thus provide an inventory of their roles in processes of Europeanization. Our ambition is essentially descriptive. We do not intend to explain why certain EU-level CSOs play one role but not another, nor to explain why they play the roles they do. Instead, we want to map the different tasks and activities that EU-level CSOs undertake and that shape their relation with $\mathrm{EU}$ institutions on the one hand and with national civil societies on the other. Our investigation is limited to three dimensions of Europeanization: organizational, financial, and regulatory. This means that we leave out their role in the other deeper dimensions of Europeanization-that is, those that aim at more thorough societal, ideational, and cognitive transformations. For each dimension we tease out the ways in which they act as subjects, objects, and mediators with the view of providing a comprehensive account of their positions vis-à-vis EU institutions as well as national civil societies. The analysis is not restricted to EU-level CSOs operations in relation to Sweden and Swedish civil society, but rather focuses on EU-level civil society per se.

Our main empirical focus is EU-level CSOs active in the fields of social policy and antidiscrimination. What is specific with this case is that it corresponds to a policy area where EU competence is relatively weak because much of the mandate on social inclusion policies lies with member states. This is, however, less so when it comes to antidiscrimination. We furthermore concentrate our analysis on EU-level CSOs being members of the umbrella organization the Social Platform (hereafter the Platform). The Platform constitutes a key case with regard to EU-level civil society organizing since it brings together the major EU-based CSOs within the fields of social inclusion and antidiscrimination (Johansson and Lee 2014, 2015; see also chapters 5 and 8 ).

The chapter makes use of the following data sources. We have used the Transparency Register for analysis of the organizational and financial dimensions of Europeanization and the LobbyFacts webpage for the 
regulatory dimension. The Transparency Register is the official EU institutional database on registered interest groups, while LobbyFacts is an initiative from Corporate Europe Observatory and LobbyControl-two CSOs that monitor lobbyists (EC 2016; Corporate Europe Observatory and LobbyControl 2016). It compiles information on the EC's high-level lobbying meetings and therefore provides an invaluable source for analyzing regulatory Europeanization. In addition to the data available there, we have also used membership in the European Economic and Social Committee's (EESC) Liaison Group (set up to strengthen cooperation with CSOs) as an indicator of access to decision-makers. The chapter also relies on a survey sent to all Platform member organizations in 2011 that tracked different kind of activities, linkages to national civil societies and patterns of cooperation of the organizations within the Platform framework (see Johansson and Lee 2014, 2015). ${ }^{1}$

The first section of the chapter provides an overview of the EU agenda on civil society involvement and how it has unfolded over time, followed by the core of the chapter, which specifies EU-level CSOs' roles in organizational, financial, and regulatory Europeanization. The final section sums up the main findings.

\section{The EU Agenda on Civil Society Involvement}

The EU discourse on civil society emerged in the late 1990s. Until then debates on civil society had been promoted by single Directorates-General (DGs) and by the EESC. The EESC took an active stance and held several conferences on the topic, supported by some DGs (Smismans 2003). ${ }^{2}$ In one of its most important position papers, the EESC defined civil society as "a collective term for all types of social action, by individuals or groups that do not emanate from the state and are not run by it" (EESC 1999, 18).

These activities paved the way for a discursive turn that took place at the start of the millennium (Fazi and Smith 2006; Finke 2007; Ruzza 2004, 2006); the publication of European Governance: $A$ White Paper was of central importance (EC 2001). Kohler-Koch and Finke (2007, 210) discuss this publication as a move toward more-participatory consultations models, in contrast to previous hierarchical and partnership-oriented models. The earlier social dialogue, made up of the labor market partners, was now complemented by the seeds of a civil dialogue engaging a broad set of CSOs (Smismans 2003, 2006). Up to this point the EU had occasionally facilitated the involvement and participation of networks of CSOs in relation to particular topics, but not as part of a coherent strategy of interaction. While EU policies and positions in the 1980s and 1990s primarily addressed social 
partner organizations or particular voluntary organizations as a source of support for European policymaking, the civil dialogue discourse started to engage all DGs and other EU institutions. That dialogue also rested on a much more inclusive conceptualization of which actors to consult and interact with as a reinforced "culture of consultation and dialogue" (EC 2001, 15).

A key tenor in the EU discourse is civil society as a solution to the EU's weak democratic legitimacy and as a way to engage citizens in EU affairs. Ideals of openness, participation, accountability, effectiveness, and coherence that color the White Paper adhered strongly to the role and function of civil society. Civil society was expected to play "an important role in giving voice to the concerns of citizens and delivering services that meet people's needs [and to provide] a chance to get citizens more actively involved in achieving the Union's objectives and to offer them a structured channel for feedback, criticism and protest" (EC 2001, 13). As such, civil society was seen to "play an important role as facilitators of a broad policy dialogue" (EC 2002, 5).

Although the range of organizations that were granted institutional access was now considerably widened, there were still important restrictions, and criteria for participation began to emerge. To partake in the civil dialogue, a civil society actor had to be "a non-profit representative body organized at European level, i.e., with members in two or more European Union or Candidate countries; be active and have expertise in one or more of the policy areas of the Commission; have some degree of formal or institutional existence; and be prepared to provide any reasonable information about itself required by the Commission" (EC 2002, 17). The EESC stressed that organizations should be independent and not bound "by instructions from outside bodies" and should be transparent with regard to their financial means and decision-making structures. It further emphasized representational credentials and held that CSOs needed to be recognized as representatives of particular groups or interests at the member state level, have members in most member states, and be authorized to act and represent at the European level (EESC 1999, 5-6). This later developed into the common consultation standards (see, e.g., EC 2015 for a recent report on the regulation of stakeholder involvement).

The ideas and ideals of the European governance White Paper (EC 2001) continued to color the EU agenda for a considerable period; it took more than a decade until another important institutional innovation took place. In 2012 the EU decided on an additional route for citizens' involvement in EU affairs, the European Citizens' Initiative (ECI). Unlike the participatory civil dialogue that relied on the aggregated interest formation of organized civil society, this avenue for participation sought to directly engage with the 
citizens of Europe, and it allowed individual citizens to propose legislation. While the ECI is heavily circumscribed in practice through massive organizational requirements, its establishment nonetheless demonstrates that the EU now values the participation of individuals in addition to the involvement of organized civil society (Hedling and Meeuwisse 2015).

However, several changes in the landscape of EU civil society have taken place in the wake of the 2008 financial crisis. Using antidiscrimination CSOs as a case of investigation, Ruzza (2015) argues that the crisis has sparked a new cycle of protests across Europe. While most of these have taken place at the national level in form of local, regional, and national anti-austerity movements, a split is growing between grassroots activists and EU-based advocacy organizations. Grassroots organizations and movement leaders are less "willing to espouse the level of institutionalization and compliance with the EU discourse that is generally taken for granted by EU advocacy groups" (Ruzza 2015, 31; see also Ruzza 2011). Such growing skeptical attitudes toward the EU have put pressure on the established set of EU-level CSOs that are engaged in EU consultation processes and civil dialogues. This could potentially lead to a change in the political culture of EU-level CSOs over the long run. At the moment, what we can discern is a widening rift between a set of institutionalized actors that operate and are firmly embedded in Brussels politics-and a set of actors who are increasingly challenging this modus operandi and the institutional actors' legitimacy to act on behalf of civil societies (e.g., della Porta 2015; della Porta and Parks 2015; Parks 2015).

This is not the first time that the EU model of consultation with CSOs has been challenged and criticized, and there has been a longstanding debate among scholars about the methods and intentions of EU institutions. As we shall see, these definitely seem to contradict traditional assumptions about civil society as autonomous and value driven, initiated from below, and engaged in contentious politics toward the targeted institutions or states. Critics have claimed that EU-level CSOs are dependent on, rather than autonomous from, EU institutions, and so are limited in what criticisms and alternatives they can put forward. They have therefore variously been called tamed, pacified, or even co-opted. Our analysis does not enable us to draw any conclusions with regards to this debate, but it can at least shed some light on the issue.

\section{Evidence of Organizational Europeanization}

A key mechanism of organizational Europeanization is the transfer of organizational models. EU-level CSOs might find themselves in three different 
position types, sometimes at different points in time, but more often simultaneously. These CSOs are the objects to organizational molding by EU institutions, but they are also subjects that actively engage in passing on organizational models to national member organizations and themselves partaking in forming new networks and alliances. Last, as mediators they might act as brokers, linkages, and/or gatekeepers in relation to other organizations.

To begin, we can see that, in general terms, most EU-level CSOs follow a certain organizational form that indicates that modeling from above has worked at least to some extent. Most of the EU-level CSOs, and certainly most of the members of the Platform, can be characterized as "formal [and] professional" organizations (della Porta and Diani 2006, 145). The great majority host their headquarters in Brussels close to the power centers that they seek to influence. They are usually governed by a board of representatives and are often led by a president or a chairperson. All of them employ staff, although the size of that staff varies. They do not rely on mass mobilization of members, but they purport to represent a particular constituencyfor instance, the poor, the old, or the unemployed-and seek to act in their interest in lobbying.

It is not a coincidence, therefore, that many EU-level CSOs follow a similar organizational logic. This reflects, as we discussed above, that EU institutions have been instrumental in forming Brussels-based branches of already existing national-level CSOs. EU-level CSOs were, and are, expected to follow established norms of representation and expertise as a requisite for gaining access to certain funding programs. Similar pressure is also put on candidate and neighbor countries as the EU supports the formation of organized civil society. The stated aim of this EU activity is "to support the development of a civil society which is participating actively in the public debate on democracy, human rights, social inclusion and the rule of law, and has the capacity to influence policy and decision making processes" (EC 2017).

Such activities demonstrate how EU institutions seek to steer the organizational forms of civil society. This contradicts "the general image of NGOs as a societal force rising to challenge or replace the state from below," and instead shows how international organizations might create and shape civil society in a top-down manner (Reimann 2006, 46). But this is not the whole story. There are also examples in which grassroots organizations have played important roles in establishing EU-level CSOs. Denis Frank's study of the Platform for International Cooperation on Undocumented Migrants (PICUM) is interesting in this respect. He found that this organization initially sought to inform and influence other CSOs operating at the EU level (refugee organizations in particular) rather than seeking to influence EU institutions and member states. The early version of PICUM also aimed to 
take a more contentious stance, defending irregular migrants vis-à-vis EU institutions because they believed that existing EU-level CSOs were too cooperative and acquiescent (Frank 2015).

Another key organizational pattern is that EU-level CSOs are organized in ever wider platforms or networks. Some of these networks have been initiated by EU institutions while others have been created by the CSOs themselves. The Platform is one example: at the time of this writing it had thirty-five full members and twelve associate members, among them the European Disability Forum (EDF), SOLIDAR, the European Anti-Poverty Network (EAPN), the European Network Against Racism (ENAR), and the European Women's Lobby (EWL) (see table 2.1; see also Cullen 2009, 2010). The Platform was set up in 1996 as a response to the EU's greater interest in broadening forms of consultation to include a wider set of civil society actors in addition to labor and business. In this context, there was a perceived need on the part of the EU to create a larger network in order to have a manageable number of CSOs to interact with (Armstrong 2002; Cullen 2010; Geyer 2001; Greenwood 2007). While the Platform was the first coalition of its kind, many others have emerged since, sometimes at even higher levels of cooperation. For instance, the Civil Society Contact Group includes the Platform and seven other value-based EU-level CSO coalitions in different fields, for instance international development, public health, and the environment. According to its webpage, the Civil Society Contact Group's members "bring together the voices of hundreds of thousands of associations across the Union [and] aim to represent the views and interests" of all these associations (Civil Society Contact Group 2018). ${ }^{3}$ Another example is the European Year of the Citizen Alliance (the Alliance), an open network of CSOs that in many different ways worked with enhancing active citizenship. The Alliance was initiated on the occasion of the European Year of the Citizen 2013 but lingered for a couple of years and included more than sixty EU-level organizations that together represented more than four thousand national CSOs (Johansson and Kalm 2015b, 6). While the EU was instrumental in promoting early coalition formations, this has been less obvious in recent years. Instead it has been largely replaced by a coalition of EU CSOs, called Civil Society Europe, comprising of almost thirty EU-level CSOs working across several policy areas (see Civil Society Europe 2018).

The ever-larger networks and coalitions are themselves arenas of interaction for EU-level CSOs. An interesting question concerns the quality and type of these interactions, especially whether they tend to promote cooperation or competition. Existing research shows elements of both. Pauline Cullen (2010) has found that the Platform allows its members to pool resources and to come to agreements on common positions, and it has even helped to develop a basic common identity for CSOs working on social issues 
and antidiscrimination. Johansson and Lee (2015), in contrast, demonstrate through a network analysis that some organizations are centrally located and others much more peripheral, which suggests that there are power asymmetries and competition between them. Competition and conflicts tend to concern access to resources, particular policy positions, as well as what issues to prioritize in dealings with $\mathrm{EU}$ institutions. Other researchers have shown that such conflicts might appear between EU-level CSOs that also work on similar topics outside the Platform context (Sánchez-Salgado 2015; Scaramuzzino and Scaramuzzino 2015; Stubbergaard 2015).

EU-level CSOs are not only agents participating in larger coalitions-but are also simultaneously themselves coalitions made up of national organizations and other members. Table 2.1 provides a snapshot of membership patterns among the Platform CSOs. Some distinguish between full and associate members, where the former have voting rights and the latter face restrictions regarding participation in internal discussions, debates, and decision-making procedures. Most are meta-organizations rather than individual-based organizations, meaning that their membership is made up of other organizations and not of persons (Ahrne and Brunsson 2008). This might be interpreted as loose connections to national civil societies because the relations are built mainly between organizations. There are exceptions, however. Some include a handful of individual members, and others a great many-the most striking being the EDF that reports 80 million members.

We also find that their spread across countries is relatively large. Most organizations are present in more than twenty of the EU's member states, and a handful are present in all of them. Such models of geographical presence certainly mirror the EU idea of representation in all member states, a norm that most seem to comply with. As we will see in the next section, those with particularly widespread representation tend to be financially resource-rich as well. However, many Platform organizations are present in countries outside the EU, some in large numbers. These non-EU countries are most often in Europe, but sometimes in other regions of the world.

Although there are some shared characteristics, extensive differences also prevail, for example with regard to the membership governance of national member organizations. Some have no limit to the number of member organizations in each country, which indicates a strong bottom-up orientation of the organization. One example is ILGA (the International Lesbian, Gay, Bisexual, Trans and Intersex Association), which has forty-two member organizations in Italy, seven in Finland, and one in Latvia. The result is that the number of members is quite uneven across countries. A different model is followed by the EWL, EAPN, and the European Network of Social Enterprises (ENSIE). They have only one full member per country, who acts as a national coordinator. This particular membership governance seems to 


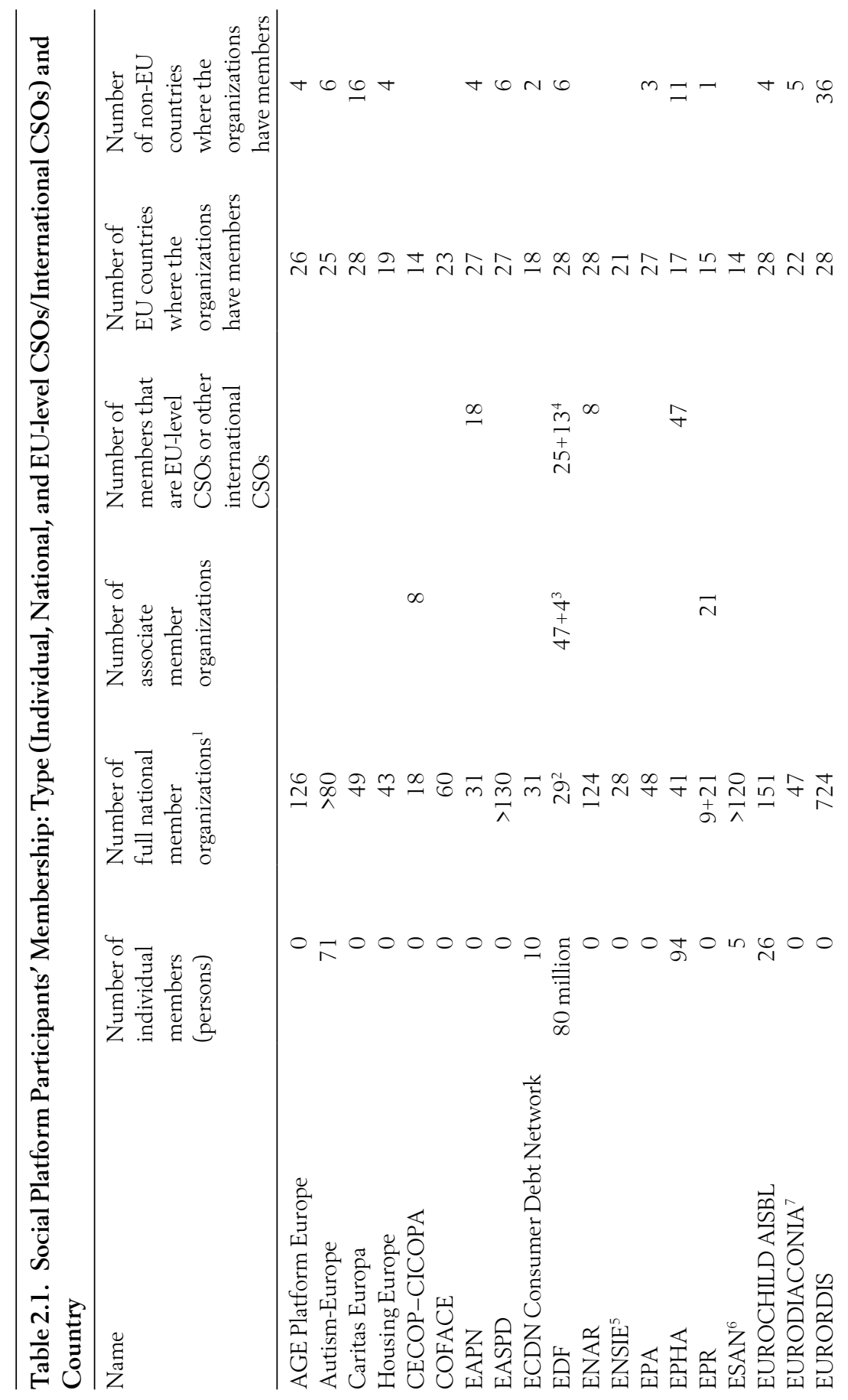

This open access library edition is supported by the University of Lund. Not for resale. 


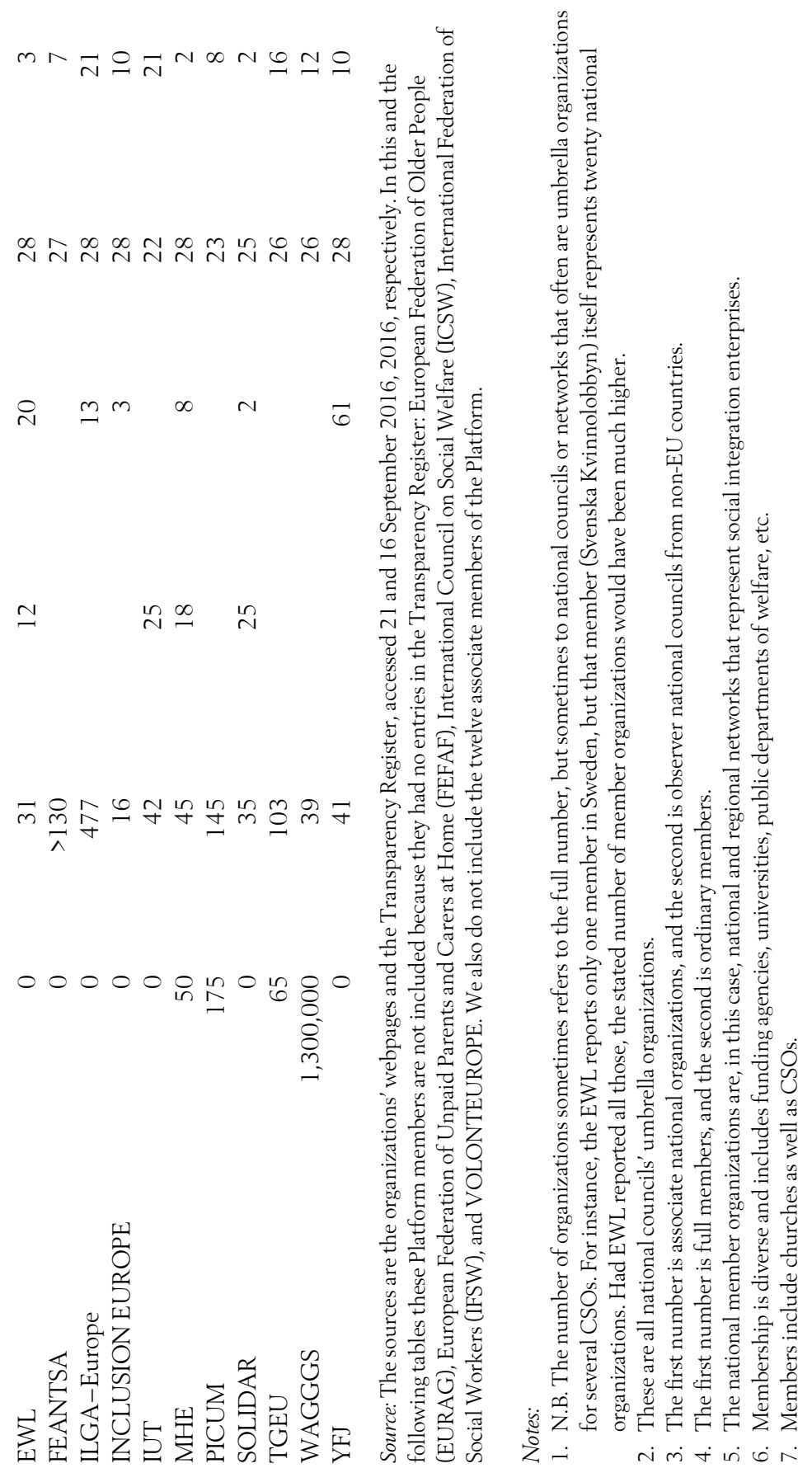

This open access library edition is supported by the University of Lund. Not for resale. 
allow for more control by the EU-level CSOs (and their secretariats) over national members because information and knowledge should be channeled through this national coordinating unit. For instance, the Swedish Women's Lobby has forty-five domestic member organizations, but none of them has direct access to the European branch of the organization. The EWL recognizes this as it states on its website that while "only this first level of membership has voting rights, their members can benefit from direct two-way information flows to and from the European level" (EWL 2017a). Such creation of a common organizational model across Europe is a clear case of organizational transfer into domestic civil societies that EU-level CSOs deploy.

\section{Evidence of Financial Europeanization}

The transfer of money is the central mechanism in financial Europeanization. In their role as subjects, EU-level CSOs actively apply for funding from various sources. When they receive funding, they are considered in our analysis to be the objects to financial Europeanization. They might occasionally also act as mediators, such as when they work as cofunders for other organizations and for different projects.

EU-level CSOs receive funding from various sources, including EU and national public funds, membership fees, grants from foundations, and donations of different kinds. An example is ENAR, which receives the lion's share of their funding as a grant from the EC. They also get large sums from foundations, such as the Open Society Initiative for Europe, the Joseph Rowntree Charitable Trust, and FOSI Black Caucus Washington. Additional incomes flow from membership fees and donations (ENAR 2016). Sometimes EU-level CSOs also receive income from expert missions and similar assignments. On occasions they hold fundraising events, such as the European Equality Gala 2015 arranged by ILGA (ILGA-Europe 2014-15).

EU institutions provide financial support in various ways. Among the EU-level CSOs investigated here, the common pattern is to receive core funding through a grant from the EC. There are programs that directly aim to support CSOs as representatives of particular societal groups and interests. The PROGRESS funding program (2007-13) provided substantial financial support for several EU-level CSOs, and it is now part of the EaSI program (European Programme for Employment and Social Innovation). The EU provides funding in several other ways too, such as through sponsoring particular projects where CSOs deliver results on a certain objective or through direct funding from the DGs (especially DG Justice and DG Sanco). 
We also find several programs that aim to build and support capacity among national-level CSOs by providing funding, information, and technical assistance through the various structural funds. It is less frequent that economic resources flow from EU-level CSOs, although that sometimes occurs too. For instance, ILGA reports that in 2014-15 it "re-granted 45 small grants for projects carried out by member organizations and partner organizations of ILGA-Europe" (ILGA-Europe 2014-15, 3).

Table 2.2 gives a brief overview of the financial structures that EU-level CSOs are embedded in. One observation is that Platform members tend to have relatively large budgets. More precisely, the median budget among all members slightly exceeds 810,000 euros. However, the size of their budgets varies a lot. The European Consumer Debt Network (ECDN) has a budget of only 12,000 euros, while the European Organisation for Rare Diseases (EURORDIS) has a budget of more than 5 million euros. The five most resource-strong organizations have budgets that exceed 2 million euros (EURORDIS, European Youth Forum [YFJ], ILGA, EAPN, and EDF). This allows them to employ more staff than others, but the staff-to-budget ratio is not wholly straightforward. EURORDIS, for instance, employs only eight full-time staff, while YFJ-with a budget of 3.2 million euros-employs twenty-eight full-time and one half-time staff. SOLIDAR has a budget of 1.1 million euros and a staff of twelve, while ILGA has a larger budget of 2.1 million euros and only 4.2 full-time staff. Apart from effects on the number of staff and other observables, it is feasible that budget size also has an effect on less tangible factors such as prestige and influence.

This illustrates some of the relations between EU institutions and EU-level CSOs, but yet another illustration of financial Europeanization can be traced through membership fees from national to EU-level CSOs; here we find that these range from 0 to 100 percent of total budgets, with a mean value of 26 percent. A closer breakdown of the figures shows that those organizations that to a very large degree rely on membership fees tend to be less reliant on EC funding, and vice versa. For instance, the budget for the European Parents' Association (EPA) comes to 83 percent from membership fees and only 6 percent from EC grants, while the YFJ receives 84 percent of their budget from the EC and only 5 percent from membership fees.

Although some actors thus have a fairly high proportion of membership funding, they are few in comparison. Only five of the thirty investigated organizations relied on membership funding for more than 50 percent of the total budget.

Instead, most of the Platform members rely on public sources from the EU. For two-thirds of the Platform members public funding surpasses half of their budget, and in some cases exceeds 80 percent. Some organizations 


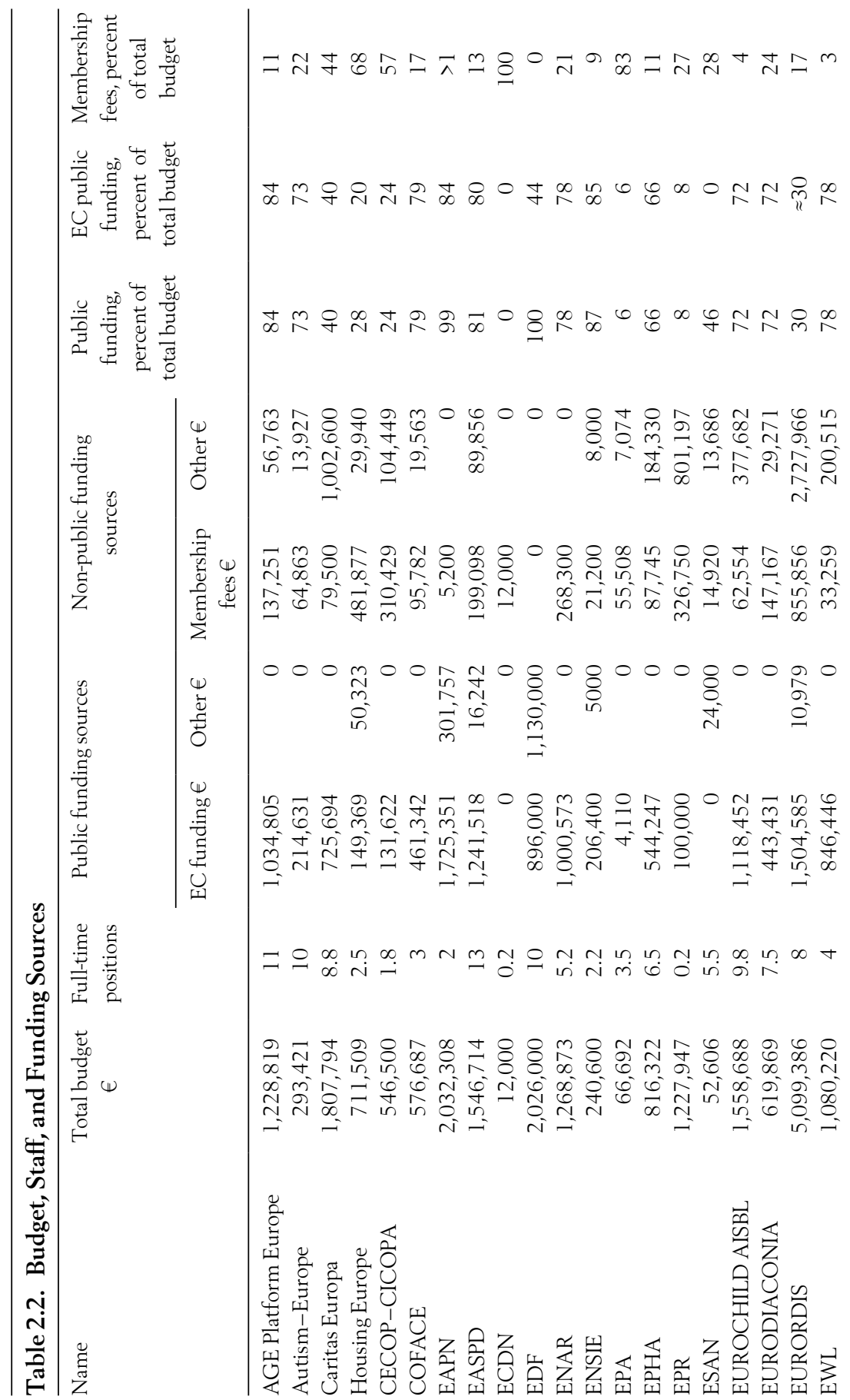

This open access library edition is supported by the University of Lund. Not for resale. 
$\sigma \circ \stackrel{N}{n} \stackrel{\infty}{\infty} \sim \stackrel{\infty}{\sim} N \underset{+}{\infty}$ in

$\infty$ 는

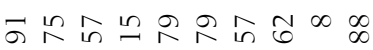

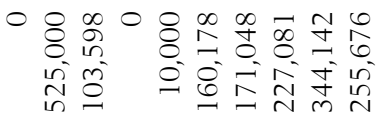

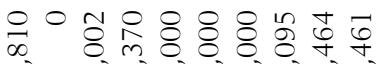

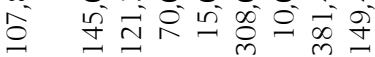

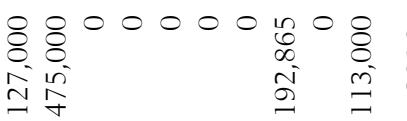

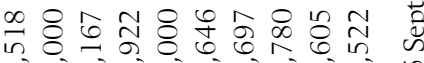

के

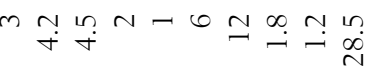

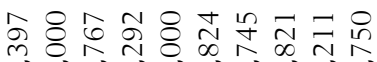

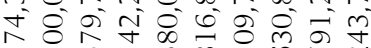

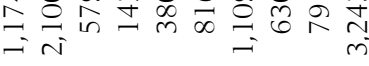

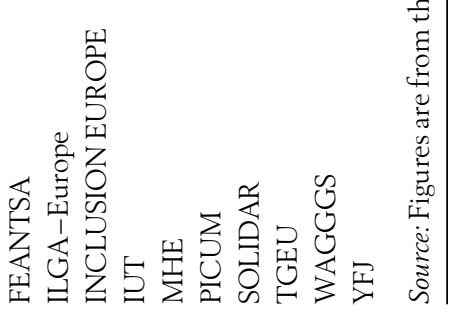

This open access library edition is supported by the University of Lund. Not for resale. 
receive sizeable public funding from non-EU sources, such as regional and national sources. This is the case for EAPN, EDF, ILGA, and Transgender Europe (TGEU). But for most, the dependency on public funding translates into a dependency on EC grants. The mean value of the share of EC grants in relation to the total budget for Platform members slightly exceeds 50 percent, and almost half of all Platform members rely on EC grants for more than 70 percent of their budgets. AGE Platform Europe (AGE), EAPN, ENSIE, and YFJ all exceed 80 percent EC funding. It is therefore clear that EU-level CSOs are highly reliant on the institutions that they are set up to monitor, consult, and influence. This finding challenges the common image of CSOs as arising from below to engage in contentious politics in opposition to particular institutions, organizations, or governments (Tilly and Tarrow 2007). It furthermore raises concern about the degree of autonomy and taming that these CSOs face. A resource dependency argument would hold that this situation pressures the organizations to conform to the views of the institution that they are set up to criticize-which assumes that whether there are explicit demands, you don't bite the hand that feeds you. ${ }^{4}$

This is why some CSOs choose not to receive any EU funding at all. Especially those CSOs that are committed to transparency and to monitoring lobbying of EU institutions stay clear of such funding. ALTER-EU (Alliance for Lobbying Transparency and Ethics Regulation), Corporate Europe Observatory, and LobbyControl are examples. They all make a point of abstaining from EU and corporate funding because they absolutely want to avoid being compromised by the actors that they are monitoring. They instead receive their funding from foundations (for instance Adessium, Isvara, Open Society, and Joseph Rowntree) along with membership fees and donations (based on analyses of data from the Transparency Register and the organizations' webpages).

While it seems obvious that these particular organizations choose this financial model given the kind of legitimacy that the field that they work in demands, it is difficult to know for sure to what extent EU funding compromises the position of CSOs working in other fields such as social issues, antidiscrimination, and development. We also cannot be sure that other financial sources would necessarily exert less pressure. In our survey distributed to Platform members, respondents were asked to describe their economic and political relation to the EU. Expectedly, the great majority ( 85 percent) considered EU institutions "partly" or "very" important as a source of funding. But there were mixed results as to whether they considered this to be a problem. On the one hand, the organizations reported that they had never limited their critique against the EU because of financial dependency-which, given that we accept their self-reporting as true-contradicts the "you don't bite the hand that feeds you" thesis. ${ }^{5}$ They also denied that they sometimes had to 
carry out projects outside their main focus in order to secure EU funding. ${ }^{6}$ On the other hand, EU funding results in a different form of adaptation from the CSOs, namely when it comes to prioritizations. A large majority (83 percent) agreed that they took into account the possibilities for EU funding when deciding what activities to prioritize. ${ }^{7}$ It therefore appears that EU funding has effects on CSO operations at least in this respect. Another observation is that the organizations clearly found their situation problematic because all of them reported that they have to look for alternative sources in order to reduce their financial dependency on the EU. ${ }^{8}$

\section{Evidence of Regulatory Europeanization}

The dimension of regulatory Europeanization by definition involves the transfer of legal norms. Here we understand the term "legal norms" broadly, including juridical aspects but also different kinds of policies, governance forms, and softer regulations. EU-level CSOs are themselves objects to regulations of $\mathrm{EU}$ institutions and member states, but they might simultaneously be subjects in regulatory Europeanization in the role of lobbyists attempting to exert political influence. They might also take on a mediating position as coregulators, especially in their relation to national members.

Advocacy work is a main objective for EU-level CSOs in general and no less for those that are a member of the Platform. The EWL, for instance, states that it "brings together the women's movement in Europe to influence the general public and European Institutions in support of women's human rights and equality between women and men" (EWL 2017b); we can find similar statements from many other Platform members.

In the literature on organized civil society, it is common to distinguish between inside lobbying and outside protest strategies (Binderkrantz 2005; Binderkrantz and Krøyer 2012). Organizations that choose the former path try to exert political influence by working with the institution in question. Concrete tactics can be formal (participating in consultations, attending meetings, and presenting written and oral statements) or informal (interactions with power holders other than formal procedures, for instance, through ad hoc meetings or correspondence). Outside protest activities often do not involve direct contact but are at the same time more confrontational. The objective is often to gain media attention that will raise awareness of their cause and force others to take action. Common forms of protest include demonstrations, occupations, petitions, and consumer boycotts (cf. Tarrow 1998, 93).

The Platform member CSOs overwhelmingly pursue inside lobbying strategies, as one would expect from professional organizations. This also 


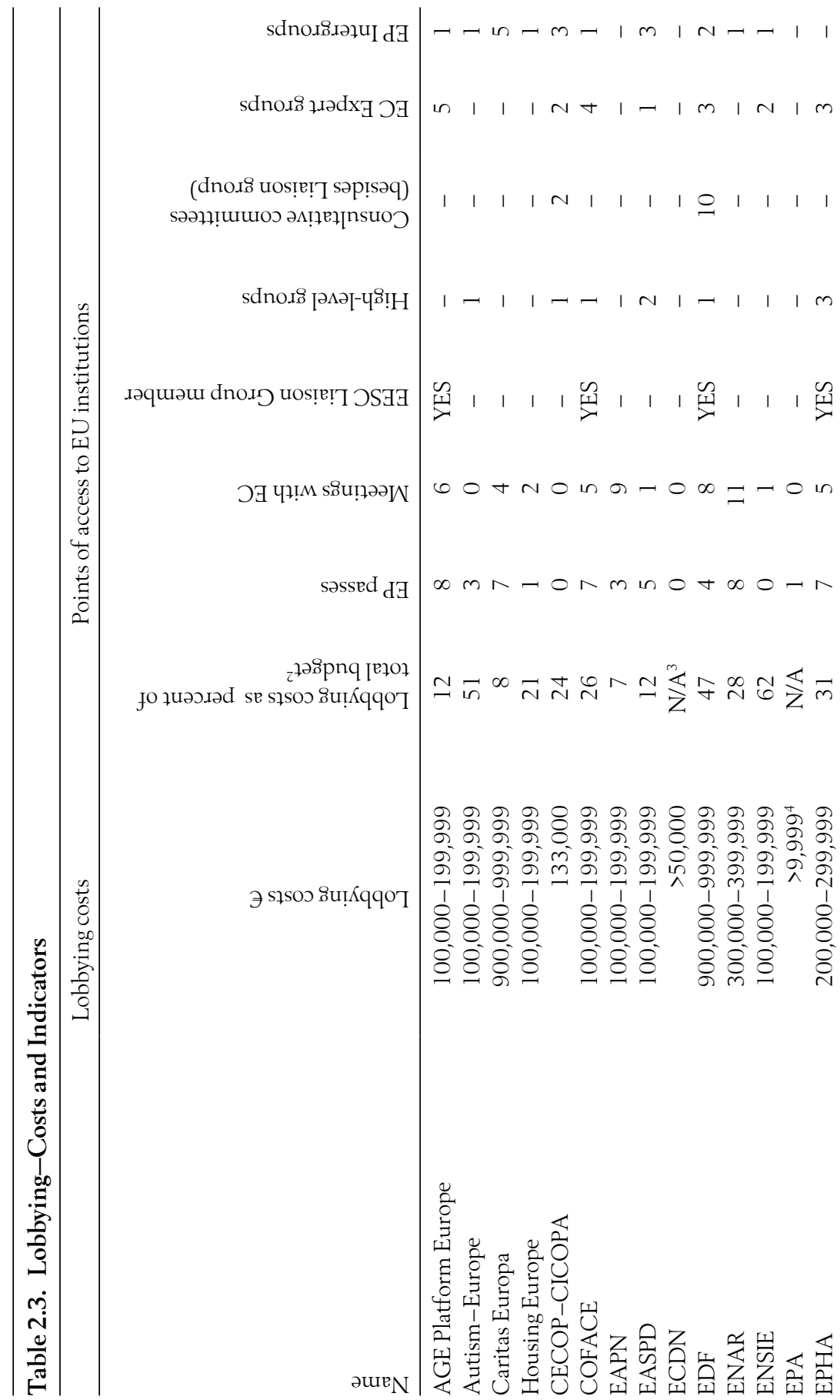

This open access library edition is supported by the University of Lund. Not for resale. 


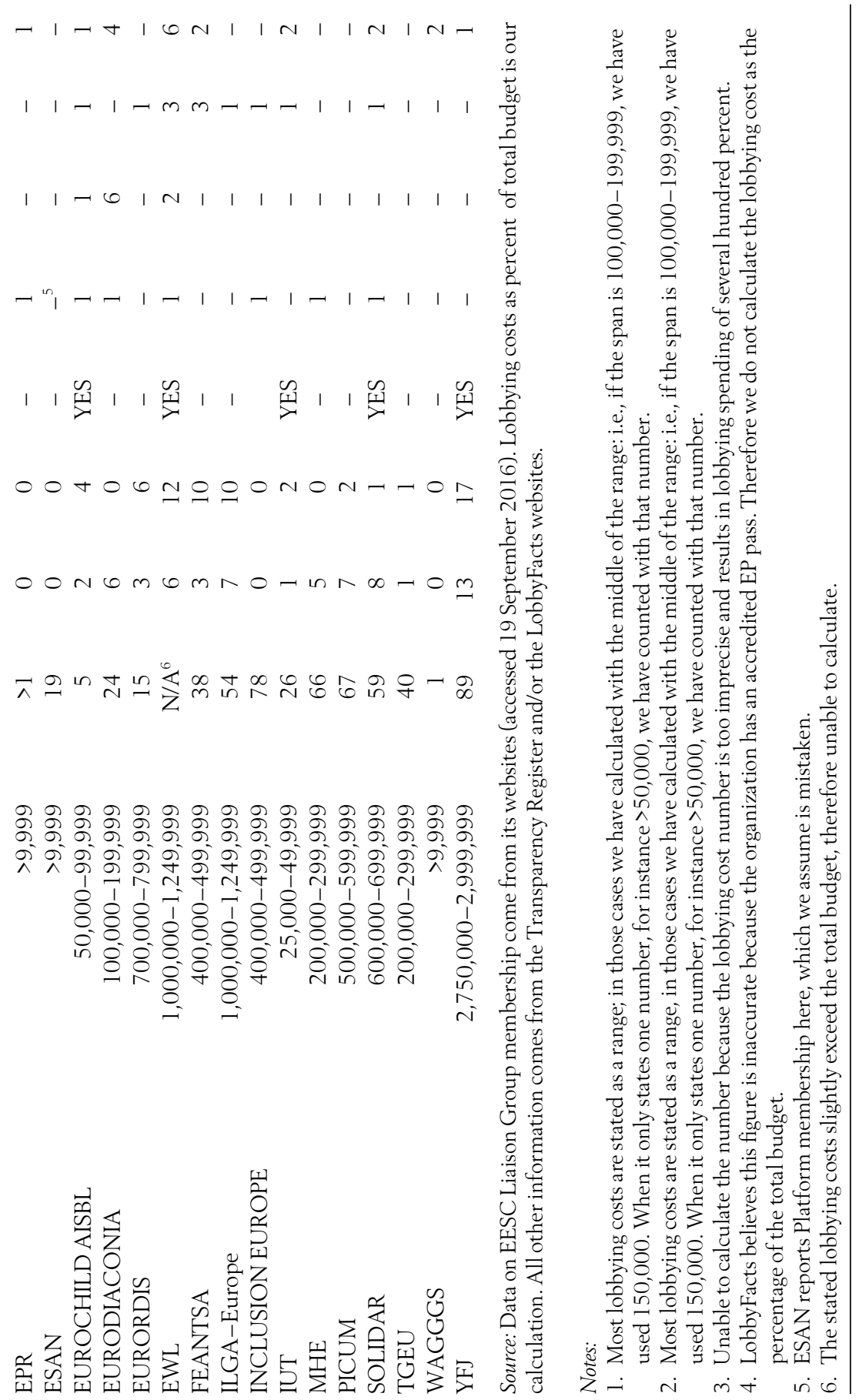


confirms the patterns observed in previous research on EU-level CSOs (Chabanet and Balme 2008; Cullen 2010; Kalm and Uhlin 2015; Kriesi, Tresch, and Jochum 2007; Sánchez-Salgado 2007; Saurugger 2006). In the survey distributed to Platform members that we mentioned in the introduction of this chapter, respondents were presented with a number of strategies and had to state which ones they used often, occasionally, or never. It turned out that the main ones were typical inside strategies such as sending position papers to $\mathrm{EU}$ institutions, serving on expert committees, making direct contact with EU officials, and participating in online consultations. Other important activities were alliance-building with other EU-level CSOs and arranging campaigns at the EU level. Outside protest strategies were used, but much more modestly. Out of the organizations participating in the survey, 62 percent said they occasionally engaged in protests and demonstrations, whereas none said they often did so. ${ }^{9}$ That some of these CSOs sometimes pursue such strategies does not mean that they could correctly be described as grassroots or mass popular organizations. Instead, they should be thought of as professional organizations that attempt to reconcile professional legitimacy and grassroots legitimacy, as discussed above. Another finding of the survey was that the organizations found direct contact with EU officials to be the most efficient tactic for influencing EU policy, while protests ranked very low in this respect. Among the EU institutions, they particularly contacted the EC and the European Parliament (EP). Among the different DGs, DG Employment and Social Affairs is the part of the EC that these actors most regularly seek contact with, followed by DG Justice and DG Education and Culture. ${ }^{10}$

This orientation toward influencing EU policies can also be illustrated by the money they spend on lobbying and their access to different points of contact with EU institutions. The data in table 2.3 provide us with a rough sketch of the CSOs' lobbying ambition and their level of connection with power holders. The first thing we note is that the share of the budget that is dedicated to lobbying varies significantly. For instance, AGE and AutismEurope spend approximately the same amounts on lobbying, but for the latter this amounts to more than half their budget and for the former only 12 percent. We also note that only seven out of the thirty CSOs included spend more than 50 percent of their budgets on lobbying costs.

We have several measures for access to EU institutions. The first two concern direct access granted by EU institutions. "EP passes" is the number of accredited pass holders to the EP that the organization has. "Meetings with EC" is extracted from the EC's websites. It includes only meetings with elite officials, for instance commissioners, cabinet members, and DGs. CSOs might have had many meetings with lower-level officials, but there are no data available for those. On these two measures, the YFJ is by far best 
connected. AGE, ENAR, and SOLIDAR rank high on EP passes, and EWL and ENAR on EC meetings. Very few organizations have neither EP passes nor EC meetings on their records.

There are also a number of selective memberships and modes of participation that provide some CSOs with privileged access to EU institutions. Membership in the EESC's Liaison Group is one example. Others are participation in high-level groups, consultative committees, EC expert groups, and $\mathrm{EP}$ intergroups. If we take these forms of participation as a measure of privileged access, the best connected of our CSOs seem to be EDF, EUROCHILD, EWL, and SOLIDAR.

All in all, this suggests that most of the Platform members are connected and integrated into the EU lobbying sphere in terms of having at least some access point to EU institutions; however, our analysis demonstrates extensive differences among the members because some have formal positions in groups and committees and regular and frequent meetings with EC high officials. There is thus a segment of insiders also among the members of the Platform, and such insider positions are likely to provide these CSOs with a more stable and central position with regard to regulatory Europeanization.

Table 2.4 shows the main lobbyists among our sample of EU-level CSOs. The ranking refers to the listing of major lobbyists among all CSOs targeting the EU-in any issue area-that have offices in Brussels. In table 2.4 we have included those Platform members that enter on the top fifty of this list (of 807 CSOs in total). As we can see, the YFJ stands out well above the rest. It has the greatest number of accredited EP passes and it has had the most meetings with the EC's top officials. The money that YFJ spends on lobbying is actually on par with the largest corporate, for-profit lobbyists. It spends approximately as much as does Siemens-which ranks eleventh on the 2016 list of for-profits (LobbyFacts 2017).

Engaging domestic member organizations in their advocacy work is an important function of EU-level CSOs. The EU-level offices-usually the secretariats-support their domestic members in various ways, for instance by exchange of expertise, the development of campaigns on specific issues, supporting domestic members' campaigns on cross-cutting issues, helping them to get access to decision-makers, and developing advocacy strategies to influence EU policies and legislation. A finding of the survey is that Platform members found it particularly important to develop toolkits that national members could use in national advocacy and to engage in capacity-building aiming at improving the member organizations' expertise on EU policy (see table 2.5). They also made efforts to provide domestic members with extensive informational support by writing reports, press releases, and short information notes on recent policy developments at the EU level. 


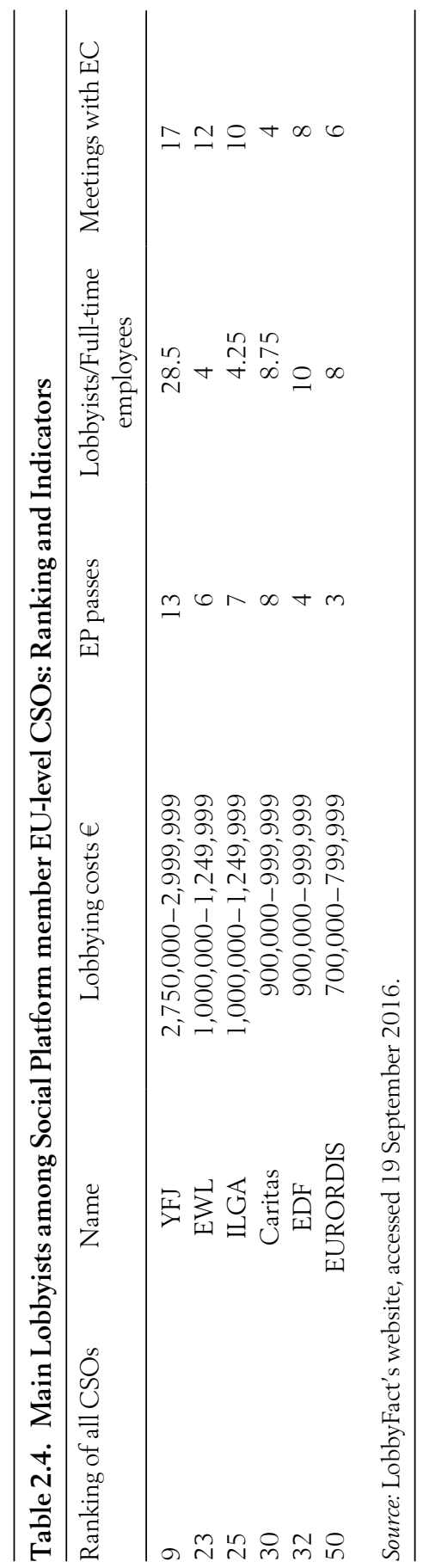

This open access library edition is supported by the University of Lund. Not for resale. 


\section{Table 2.5. Relations to National Member Organizations}

\begin{tabular}{|c|c|c|c|}
\hline & Strongly agree & Partly agree & Disagree \\
\hline \multicolumn{4}{|l|}{ We put our efforts into ... } \\
\hline $\begin{array}{l}\text {... regularly informing our members } \\
\text { about our organization's ongoing } \\
\text { work at the EU level and in the Social } \\
\text { Platform }(\mathrm{N}=2 \mathrm{l})\end{array}$ & 16 & 5 & 0 \\
\hline $\begin{array}{l}\text {... trying to work on issues that are of } \\
\text { significance for our national members } \\
(\mathrm{N}=21)\end{array}$ & 20 & 1 & 5 \\
\hline $\begin{array}{l}\ldots \text { developing toolkits that our } \\
\text { members can use in national policy } \\
\text { work }(\mathrm{N}=21)\end{array}$ & 11 & 10 & 0 \\
\hline $\begin{array}{l}\text {... capacity-building activities for our } \\
\text { members in order to improve their } \\
\text { expertise in EU policies }(\mathrm{N}=21)\end{array}$ & 16 & 5 & 0 \\
\hline \multicolumn{4}{|l|}{ Our members... } \\
\hline $\begin{array}{l}\text {... regularly provide information } \\
\text { regarding conditions and policies from } \\
\text { national contexts }(\mathrm{N}=20)\end{array}$ & 11 & 10 & 0 \\
\hline Source: Own survey to members of the Soc & Platform. & & \\
\hline
\end{tabular}

At the same time, such information is processed upward from the local, regional, and national level to the EU offices. The members support the development of information reports and position papers by completing surveys, evaluate and monitor EU-driven projects at national and local levels, and write reports on national developments. All the respondents in our survey stated that their members regularly provide them with information regarding conditions from national contexts. ${ }^{11}$

\section{Conclusion}

Civil society actors have largely been neglected in the literature on Europeanization. In this chapter we have examined functions that one particular civil society actor-namely EU-level CSOs-might have in this context. Our aim has been to provide a comprehensive and structured analysis of such functions and activities. We have therefore investigated their roles in the organizational, financial, and regulatory dimensions of Europeanization. It has been suggested in previous research that CSOs of this kind act as transmission belts between the European and national levels (Kohler-Koch 2010; Steffek and Hahn 2010; Steffek, Kissling, and Nanz 
2008; Tomšič and Reik 2008). There is no doubt that this is crucial because acting in this intermediary fashion is a requirement for the transmission tasks (of organizational models, financial resources, and regulations) that are at the core of Europeanization processes. But the transmission belt metaphor leaves aside the roles as both object and subject, or taker and creator, in Europeanization that we find vital for grasping the breadth of their agency. As subjects, they actively engage in shaping Europeanization. And as objects to Europeanizing regulations, organizational pressures, and funding requirements, they themselves are shaped.

EU-level CSOs' involvement in organizational Europeanization demonstrates their triple roles. They are the targets of EU officials' ambitions and they tend to follow a similar organizational model that suits the field and the activities they are expected to engage in as part of the EU policy process. Their organizational model is to a conspicuous degree constructed from the top down rather than from the bottom up (even if there are some examples of that, too). The model favored by the $\mathrm{EU}$ is also passed on to candidate countries' civil societies. But EU-level CSOs are also subjects and mediators in organizational Europeanization, and they take action in forming everlarger networks and coalitions with other CSOs at the European level. They also pass on the organizational model favored by the $\mathrm{EU}$ in their interactions with national-level civil society. This is particularly noticeable in those cases when national alliances or contact points are created. This is considered attractive by the EU institutions because national organizations are then expected to finalize internal discussions and negotiations before engaging with their EU counterparts. It is easier to address, negotiate, and discuss with one domestic actor rather than with a wide set of actors with potentially disparate interests. In these cases, it is the EU-level CSOs themselves that mold the organizational features of national civil society, for similar reasons that the EC finds EU-level alliances preferable in EU politics. The pressure of compliance put on EU-level CSOs is translated and incorporated into their internal relations with members. This might put them on a tightrope as top-down organizational and membership steering might risk their ability to have their ears to the ground and hence the legitimacy to speak on behalf of national civil societies. While this is an overall pattern, we find elements of firm bottom-up organization and actors that seem to build much more on the involvement of domestic CSOs, and a wider variety and set of actors is involved in their internal membership governance.

EU-level CSOs' engagement in financial Europeanization also involves roles as subjects, objects, and mediators. The EU provides central funding for several Platform members, and for a majority of the CSOs this is their main source of income. Despite the fact that we find diversification of funding sources, the flows of money largely come from EU institutions, and 
EU-level CSOs to a large extent position themselves at the receiving end. This suggests a certain degree of limitation to their agency because they are dependent on EU funding for their operations and potentially must adjust their activities to adapt to an EU agenda. But they are also at the receiving end when it comes to financial resources from members, even though the significance of domestic sources of funding-especially membership fees-is more limited. While this certainly reflects the status of members of the Platform, financial Europeanization can also involve the direct relation between EU sources of funding and domestic CSOs. Structural funds and specialized programs have provided domestic CSOs with substantial financial support, and here we anticipate that EU-level CSOs might have provided domestic CSOs with knowledge and information on access and capability-promoting activities. The extensive forms of financial dependency on EU funding raises key questions on their autonomy and independence, yet previous studies confirm that also other factors play an important part to depict the complex function of public funding (e.g., Arvidson, Johansson, and Scaramuzzino 2017).

Our analysis of regulatory Europeanization positions these EU-level CSOs as having a distinctive role as lobbyists vis-à-vis the EU and various EU institutions. Several of them are resolutely embedded in EU politics, have wide accreditation in key EU institutional arenas, and have sufficient status to hold regular bilateral meetings with high-ranking EU officials. A small group of actors stand out in this respect as an insider elite group-in other words, a set of established actors among the already established, with similar status as some of the largest business-focused lobbying organizations. Although they deny the picture of being incorporated, tamed, and included in the EU machinery, because they often take the form of the object to the EU's regulatory and norm-setting practices, this risk again seems hard to avoid. Their ambition to influence EU policies is mirrored by a fairly lukewarm orientation toward their members in this respect. Although most of them engage with members in terms of building campaigns, collecting information, and providing expertise at the national level-acting as a mediator between levels-their main focus definitely lies in seeking to have an impact on EU policies. This reflects a gap between local/national CSOs and EU-level CSOs, which to a greater extent see their mission and social basis in Brussels rather than as firmly embedded and being part of European civil societies.

These discussions provide new insight into the dual role of EU-based CSOs. The analysis indicates generally a strong gravity and orientation toward the EU arena and institutions among EU-based CSOs. Connections and links to domestic CSOs above all regard to organizational Europeanization, yet less so within the other two dimensions of Europeanization. While 
previous studies have observed that EU-level CSOs might run the risk of primarily being a target for EU governance and regulation, similar concerns can be raised with regard to their connections to domestic civil societies. This provides a somewhat pessimistic assessment for those who wish for a vibrant EU civil society to emerge. But one should remember that we are now exclusively concerned with professional EU-level CSOs; outside this group there may well be elements and actors that have the potential to provide other links and contacts and play different roles in Europeanization processes (see e.g. della Porta and Caiani 2009, Teune 2010). Whether they can bridge and link domestic civil societies with EU civil society is a matter for future investigations.

Håkan Johansson is Professor of Social Work at the School of Social Work, Lund University, Sweden. His research interests include civil society, EU, advocacy, social policy, poverty and elites. He is currently leading a research program on civil society elites in Europe (funded by the Swedish Foundation for Humanities and Social Sciences) and recently published a book titled $E U$ Civil Society: Patterns of Cooperation, Competition and Conflict (coedited with Sara Kalm, Palgrave 2015).

Sara Kalm is Associate Professor of Political Science at Lund University in Sweden. Her main research areas are civil society and migration policy. She is coeditor with Håkan Johansson of the volume EU Civil Society: Patterns of Cooperation, Competition and Conflict (Palgrave, 2015).

\section{Notes}

1. The response rate was 57 percent of the full members of the Platform. This survey has been used in earlier publications (Johansson and Lee 2014, 2015), but the parts that are used in this chapter are previously unpublished.

2. See, for instance, conferences such as "Social Economy and the Single Market," 12 October 1999; "First Convention of Civil Society Organised at European Level," 15 and 16 October 1999; "Choosing Our Future: Shaping the Sixth EU Environment Action Programme-Views from Civil Society," 7 March 2001; "Shaping the Strategy for a Sustainable European Union: Views from Civil Society and Public Authorities," 26 and 27 April 2001; "Conference on the Role of Organised Civil Society in European Governance," 8 and 9 November 2001.

3. In addition to the Platform, the other members are the European CSOs Confederation for Relief and Development (CONCORD), Culture Action Europe, the Forum for the Arts and Heritage, the European Public Health Alliance (EPHA), the European Civil Society Platform on Lifelong Learning (EUCIS-LLL), the EWL, Green 10, and the Human Rights and Democracy Network (HRDN). 
4. One Platform member, EURORDIS, appears to be an exception to the rule. By far the financially strongest of Platform member organizations, only 30 percent of its budget comes from the EC and 17 percent comes from membership fees. A large share of the budget of this patient organizations' alliance instead comes from other sources, particularly from health sector corporates.

5. When presented with the statement "We have never limited our critique towards EU policies due to the financial support we receive from EU institutions," thirteen out of eighteen strongly agreed and two partly agreed.

6. A total of thirteen of eighteen disagreed and two partly agreed to the statement "For financial reasons, we sometimes have to carry out EU projects that are outside of our organisation's main focus."

7. Seven strongly agreed and eight partly agreed to the statement, "When we decide what activities to prioritise, we consider the possibilities for EU funding."

8. To the statement "We are looking for alternative funding sources, other than those from EU institutions, to reduce our dependency on EU funding," six of eighteen partly agreed and twelve strongly agreed.

9. The question read, "What kinds of activities does your organisation employ in order to influence the EU's policies?" and there were thirteen alternatives.

10. Here, the respondents were asked to state which of the thirteen alternatives (mentioned above) they found most effective and second-most effective for influencing EU policy.

11. The respondents were asked to consider if their national member organizations "regularly provide information regarding conditions and policies from national contexts." Ten partly agreed and eleven strongly agreed (of twenty-one in total).

\section{References}

Ahrne, Göran, and Nils Brunsson. 2008. Meta-organizations. Cheltenham, UK: Edward Elgar.

Armstrong, Kenneth A. 2002. "Rediscovering Civil Society: The European Union and the White Paper on Governance." European Law Journal 8, no. 1: 102-32.

Arvidson, Malin, Håkan Johansson, and Roberto Scaramuzzino. 2017. "Advocacy Compromised: How Financial, Organizational and Institutional Factors Shape Advocacy Strategies of Civil Society Organizations,' Voluntas: International Journal of Voluntary and Nonprofit Organizations, https://doi.org/10.1007/s 1 1266-017-9900-y

Chabanet, Didier, and Richard Balme. 2008. European Governance and Democracy: Power and Protest in the EU. Lanham, MD: Rowman and Littlefield.

Binderkrantz, Anne. 2005. "Interest Group Strategies: Navigating Between Privileged Access and Strategies of Pressure.” Political Studies 53: 694-715.

Binderkrantz, Anne, and Simon Krøyer. 2012. "Customizing Strategy: Policy Goals and Interest Group Strategies." Interest Group and Advocacy 1, no. 1: 115-38.

Civil Society Contact Group. 2018. "Presentation." Accessed 6 August 2018, from http://www.act4europe.org/code/en/default.asp.

Civil Society Europe. 2018. "Who We Are." Brussels. Belgium. Accessed 14 August 2018, from https://civilsocietyeurope.eu/about/. 
Corporate Europe Observatory and LobbyControl. 2016. "LobbyFacts." Accessed September 2016, from https://lobbyfacts.eu/about-lobbyfacts.

Cullen, Pauline. 2009. "Pan European NGOs and Social Rights: Participatory Democracy and Civil Dialogue." In Transnational Activism in the UN and the EU: A Comparative Study, edited by Jutta M. Joachim and Birgit Locher, 134-146. New York, NY: Routledge.

— 2010. "The Platform of European Social NGOs: Ideology, Division and Coalition." Journal of Political Ideologies 15, no. 3: 317-31.

della Porta, Donatella. 2015. Social Movements in Times of Austerity: Bringing Capitalism Back In. Oxford, UK: Polity Press.

della Porta, Donatella, and Mario Diani. 2006. Social Movements: An Introduction. Malden, MA: Blackwell.

della Porta, Donatella, and Manuela Caiani. 2009. Social Movements and Europeanization. Oxford, UK: Oxford University Press.

della Porta, Donatella, and Louisa Parks. 2015. "Europeanisation and Social Movements: Before and after the Great Recession." In European Integration, Processes of Change and the National Experience, edited by Stefanie Börner and Monika Eigmüller, 255-278. Basingstoke, UK: Palgrave Macmillan.

EESC. 1999. Opinion of the Economic and Social Committee on the Role and Contribution of Civil Society Organisations in the Building of Europe (1999/C 329/10). Brussels, Belgium: European Economic and Social Committee.

EC. 2000. Shaping the New Europe: Strategic Objectives 2000-2005. COM 154 final. Brussels, Belgium: European Commission.

—. 2001. European Governance: A White Paper. COM 428 final. Brussels, Belgium: European Commission.

- 2002. Towards a Reinforced Culture of Consultation: General Principles and Minimum Standards for Consultation of Interested Parties by the Commission. COM 704 final. Brussels, Belgium: European Commission.

—. 2015. Better Regulation Guidelines. 19.5.2015. SWD (2015) 111 final. Brussels, Belgium: European Commission.

—. 2016. "Transparency Register." Accessed September 2016, from http://ec.europa. eu/transparencyregister/public/consultation/search.do?locale $=$ en\&reset=

—. 2017. "Civil Society." Retrieved 14 February 2017, from https://ec.europa.eu/ neighbourhood-enlargement/policy/policy-highlights/civil-society_en.

ENAR. 2016. "ENAR AISBL Global Overview." Retrieved 14 February 2017, from http://www.enar-eu.org/IMG/pdf/3._finances_2015_global_overview_final.pdf

EWL. 2017a. "Our Membership." Retrieved 14 February 2017, from http://www.womenlobby.org/-our-membership-?lang=en.

—. 2017b. "Mission, Vision and Values." Retrieved 14 February 2017, from http:// www.womenlobby.org/Mission-vision-and-values-588?lang=en.

Fazi, Elodie, and Jeremy Smith. 2006. Civil Dialogue: Making It Work Better. Civil Society Contact Group. Retrieved 5 February 2015, from http://act4europe.horus.be.

Finke, Barbara. 2007. "Civil Society Participation in EU governance." Living Reviews in European Governance 2, no. 2 Retrieved 6 August 2018, from http://www.livingreviews.org/lreg-2007-2.

Frank, Denis. 2015. "The Formation of an EU-Based CSO: A Case Study of the Platform for International Cooperation on Undocumented Migrants." In Johansson and Kalm, EU Civil Society, 155-72. 
Geyer, Robert R. 2001. "Can European Union Social NGOs Co-operate to Promote EU Social Policy?” Journal of Social Policy 30, no. 3: 477-93.

Greenwood, Justin. 2007. "Review Article: Organized Civil Society and Democratic Legitimacy in the European Union.” British Journal of Political Science 37, no. 2: $333-57$.

Hedling, Elsa, and Anna Meeuwisse. 2015. “The European Citizens' Initiative Stage: A Snapshot of the Cast and Their Acts." In Johansson and Kalm, EUCivil Society, 210-28.

ILGA-Europe. 2014-15. ILGA-Europe Activity Report 2014-2015. Retrieved 6 August 2018, from https://www.ilga-europe.org/sites/default/files/Attachments/ar_20132014.pdf.

Johansson, Håkan, and Sara Kalm, eds. 2015a. EU Civil Society. Patterns of Cooperation, Competition and Conflict. Basingstoke, UK: Palgrave Macmillan.

— 2015b. "Thinking Relationally: Questions, Themes and Perspectives for the Study of EU Civil Society." In Johansson and Kalm, EU Civil Society, 1-20.

Johansson, Håkan, and Jayeon Lee. 2014. "Bridging the Gap: How Do EU-Based Civil Society Organisations Acquire Their Internal Representation?" VOLUNTAS: International Journal of Voluntary and Nonprofit Organizations 25: 405-24.

- 2015. "Competing Capital Logics in the Field of EU-Level CSOs: 'Autonomy from' or 'Interconnectedness with' the EU?" In Johansson and Kalm, EU Civil Society, $61-80$.

Kalm, Sara, and Anders Uhlin. 2015. Civil Society and the Governance of Development: Opposing Global Institutions. Basingstoke, UK: Palgrave Macmillan.

Ketola, Markus. 2013. Europeanization and Civil Society: Turkish NGOs as Instruments of Change. Basingstoke, UK: Palgrave Macmillan.

Kohler-Koch, Beate. 2010. “Civil Society and EUDemocracy: 'Astroturf' Representation?” Journal of European Public Policy 17, no. 1: 100-16.

Kohler-Koch, Beate, and Barbara Finke. 2007. "The Institutional Shaping of EU-Society Relations: A Contribution to Democracy via Participation?” Journal of Civil Society 3, no. 3: 205-21.

Kohler-Koch, Beate, and Berthold Rittberger, eds. 2007. Debating the Democratic Legitimacy of the European Union. Lanham, MD: Rowman and Littlefield.

Kriesi, Hanspeter, Anke Tresch, and Margit Jochum. 2007. "Going public in the European union: Action repertoires of western European collective political actors." Comparative Political Studies 40, no. 1: 48-73.

LobbyFacts. 2017. "Big Lobby Spenders: 2012 vs. 2016 Changes in the EU Top 50.” Retrieved 14 February 2017, from https://lobbyfacts.eu/files/attachment/spread sheet_top_spenders_2012_2016_updated.pdf.

Monaghan, Elizabeth. 2012. "A Nascent Transnational Civil Society." In European Disunion: Between Sovereignty and Solidarity, edited by J. Hayward and R. Wurzel, 32-47. Basingstoke, UK: Palgrave Macmillan.

Parks, Louisa. 2015. Social Movement Campaigns on EU Policy: In the Corridors and in the Streets. Basingstoke, UK: Palgrave Macmillan.

Reimann, Kim D. 2006. "A View from the Top: International Politics, Norms and the Worldwide Growth of NGOs." International Studies Quarterly 50: 45-67.

Ruzza, Carlo. 2004. Europe and Civil Society: Movement Coalitions and European Institutions. Manchester, UK: Manchester University Press.

—. 2006. "European Institutions and the Policy Discourse of Organised Civil Society." In Smismans, Civil Society and Legitimate European Governance, 169-95. 
2011. "Social Movements and the European Interest Intermediation of Public Interest Groups.” Journal of European Integration 33, no. 4: 453-69.

- 2015. "Changes in the Field of EU Civil Society Organisations: Institutionalisation, Differentiation and Challengers." In Johansson and Kalm, EU Civil Society, 23-42.

Sánchez-Salgado, Rosa. 2007. "Giving a European Dimension to Civil Society Organizations." Journal of Civil Society 3, no. 3: 253-69.

—. 2014. Europeanizing Civil Society: How the EU Shapes Civil Society Organizations. Basingstoke, UK: Palgrave.

—. 2015. "Exploring Competition and Cooperation among EU-Based International Solidarity Civil Society Organisations: The Relevance of Values, Resources and External Support." In Johansson and Kalm, EU Civil Society, 98-116.

Saurugger, Sabine. 2006. "The Professionalization of Interest Representation? Associative Democracy and EU Funding of Civil Society Organizations.” In Smismans, Civil Society and Legitimate European Governance, 260-276.

Scaramuzzino, Roberto, and Gabriella Scaramuzzino. 2015. "Sex Workers' Rights Movement and the EU: Challenging the New European Prostitution Policy Model." In Johansson and Kalm, EU Civil Society, 137-54.

Smismans, Stijn. 2003. "European Civil Society: Shaped by Discourses and Institutional Interests." European Law Journal 9, no. 4: 473-95.

—, ed. 2006. Civil Society and Legitimate European Governance. Cheltenham, UK: Edward Elgar.

Steffek, Jens, and Kristina Hahn, eds. 2010. Evaluating Transnational NGOs: Legitimacy, Accountability, Representation. Basingstoke, UK: Palgrave Macmillan.

Steffek, Jens, Claudia Kissling, and Patrizia Nanz. 2008. Civil Society Participation in European and Global Governance: A Cure for the Democratic Deficit? Basingstoke, UK: Palgrave Macmillan.

Stubbergaard, Ylva. 2015. "Conflict and Cooperation: Interactions among EU-Level Civil Society Organisations in the Field of Gender Equality." In Johansson and Kalm, EU Civil Society, 119-36.

Tilly, Charles, and Sidney Tarrow. 2007. Contentious Politics. Oxford, UK: Oxford University Press.

Teune, Simon, ed. 2010. The Transnational Condition: Protest Dynamics in an Entangled Europe. New York, NY: Berghahn Books.

Tarrow, Sidney. 1998. Power in Movement: Social Movements and Contentious Politics. Cambridge, UK: Cambridge University Press.

Tomšič, Matevž, and Mateja Rek. 2008. "Governance and Civil Society at the EU Level.” Managing Global Transitions 6, no. 4: 403-20.

Warleigh, Alex. 2001. "Europeanizing Civil Society: NGOs as Agents of Political Socialization." Journal of Common Market Studies 39, no. 4: 619-39. 
This open access library edition is supported by the University of Lund. Not for resale. 
Chapter 3

\title{
EUROPEANIZATION OF SWEDISH CIVIL SOCIETY Motives, ACtivities, ANd Perceived Consequences
}

\author{
Roberto Scaramuzzino and Magnus Wennerhag
}

This chapter explores the extent to which Swedish civil society organizations (CSOs) Europeanize. The chapter focuses on regulatory, organizational, and financial Europeanization and on activities such as attempts to influence policy at the European level, participation in European networks, and applying for funding from EU institutions. The chapter's aim is to offer a broad picture of CSOs' Europeanization-their advocacy activities, participation in European networks, and use of EU funding-by focusing on these actors' activities, motives, and the consequences they experience from taking part in various Europeanized activities. In addition to showing the overall patterns of all CSOs we will compare different organizational types to address whether different types of CSOs working with different issues show different patterns of Europeanization. All data presented in this chapter are based on results from a national survey among CSOs conducted in 2012 as part of the EUROCIV research program.

The survey was answered by 2,791 Swedish CSOs, which makes it one of the largest civil society surveys ever conducted in Sweden. ${ }^{1}$ Large quantitative studies of Swedish CSOs are rare. However, in the 1990s Sweden participated in the Johns Hopkins Comparative Nonprofit Sector Project, comparing civil society sectors in more than forty countries (Salamon, Sokolowski, and List 2004). This Swedish study (Lundström and Wijkström 1997) was replicated in 2002 (Wijkström and Einarsson 
2006). These studies aimed at mapping the Swedish civil society sector; they focused mostly on the organizations' workforce (both paid staff and volunteers), their sources of income, and the types of activities they were involved in. A smaller survey study was also conducted in 2013 including mostly well-established local CSOs in three policy areas-disability, gender equality, and homelessness-on topics related to voice and service roles. This study involved part of the research team from the EUROCIV research project, and the questionnaire replicated some of the questions used in the EUROCIV survey (Arvidsson and Johansson 2015). Since 2012 the Swedish National Board for Youth Affairs (which in 2014 was renamed the Swedish Agency for Youth and Civil Society [MUCF]) has conducted a yearly survey focusing on the financial conditions of CSOs and their experiences of contacts with Swedish public authorities (Ungdomsstyrelsen 2013). The most recent report had a particular focus on work with immigrants (MUCF 2016).

Previous studies about the Europeanization of Swedish CSOs have foremost been based on qualitative data (e.g., interview studies as in Olsson et al. 2009; Scaramuzzino 2012). The few quantitative studies that have been carried out have focused on specific aspects of EU policies (e.g., European Social Fund [ESF] funding in Scaramuzzino et al. 2010) and have not analyzed large samples containing a wide range of CSO types. We are in fact not aware of any survey study, neither in Sweden nor in other countries, that has addressed the Europeanization of domestic CSOs from such a broad perspective and included as many dimensions of Europeanization as we did in the EUROCIV survey.

\section{Points of Departure}

Europeanization is often understood, as argued in this book's introduction, as the adding of another layer in a multilevel system of governance, and this new layer creates new political opportunities for CSOs. Swedish CSOs have traditionally been embedded in a nationally structured system whose main political levels are the local/municipal level and the national level. As will be shown in our analysis, Swedish organized civil society is mainly composed of local grassroots organizations (cf. Ungdomsstyrelsen 2013). For these local organizations, the municipal level constitutes the most important focus of their political activities and their efforts to mobilize resources. At the same time, many Swedish CSOs have over the years sought to organize themselves at the national level-through federations and umbrella organizations-for the purpose of being represented vis-à-vis the state (see Aytar 2007 for a discussion of immigrant organizations). With the adding of the European 
political level, one might expect a similar need to be represented vis-à-vis the European Union (EU) (e.g., Ahrne and Brunsson 2005).

In order to properly understand the degree to which Swedish CSOs are Europeanized with regard to their efforts to influence politics, to take part in organizational networks, or to seek economic resources, one has to compare their degree of engagement in such activities with how they take part in similar activities at the local and national levels. In our questionnaire we therefore included not only questions about various CSOs' activities on the European level, but also questions about their corresponding activities on the national and local levels.

Furthermore, while Europeanization implies a form of transnationalization of CSOs' activities, it is not the only way in which they engage in transnational activities. As discussed in the introduction, Swedish EU membership dates back to 1995, but Nordic and international forms of cooperation involving Swedish CSOs were a fact long before that. Although the EU is the only supranational level of political decision-making that is really able to make binding decisions concerning many policy areas, there are other supranational levels where political decisions are taken that can be relevant for Swedish CSOs. From a Swedish perspective, this applies especially to bodies for cooperation between the Nordic countries (the Nordic Council and the Nordic Council of Ministers) and on the international level (first and foremost the UN). Furthermore, many of the social movements that have had a prominent role in shaping modern Sweden were originally imported from continental Europe (e.g., the trade unions and the labor movement), or from the United States (e.g., many nonstate Lutheran churches and the temperance movement), and they were thus from the beginning part of transnational movement networks (Lundström and Wijkström 1997). Swedish CSOs' affiliations with Nordic and international umbrella organizations can in fact date back to the late nineteenth century or the beginning of the twentieth century (e.g., the Swedish Red Cross).

To better understand whether Swedish CSOs take part more or less extensively in the specific type of transnationalization that we name "Europeanization," one also has to scrutinize the degree to which they take part in other types of transnational activities. In our questionnaire we therefore asked about the CSOs' degree of engagement in networks and political activities on both the Nordic and international levels. In the analysis we consistently compared figures indicating different types of Europeanization with comparable data relating to these other supranational levels.

It is also important to consider that different types of organizations might have different motives to Europeanize, might engage in different activities relating to different types of Europeanization, and might experience different outcomes. Hence the organizations examined in this chapter 
were manually categorized into ten different organizational types. ${ }^{2}$ In fact, previous research has shown that organizational type is a relevant factor behind whether an actor is present and active at different geographical levels (Beyers 2004, 2008; Beyers and Kerremans 2007; Johansson, Scaramuzzino and Wennerhag 2018). In accordance with this literature our categorization allows us to distinguish between diffuse and specific interests. Because we include a broad range of CSOs we also want to compare organizations representing different groups and active on different policy issues. Beyers and Kerremans $(2012,268)$ argue, "If groups face issues where the potential effects of policy changes are high, the incentive to seek recourse at other levels of government is also high." In other words, organizations are more likely to engage at the supranational level if the policy issue they are involved in can be considered threatening, salient, and costly to that organization (at that specific level) (Beyers and Kerremans 2012).

The first six organizational types are all interest organizations that work for and represent the specific interests of particular social groups in the population. The types are (1) disability organizations, (2) temperance and drug users' organizations, (3) trade unions, (4) victim support organizations, (5) women's organizations, and (6) other interest organizations (e.g., pensioner; immigrant; and lesbian, gay, bisexual, and transgender [LGBT] organizations). ${ }^{3}$ We have chosen to include both CSOs that represent client groups and those that represent trade unions. Even if the collective identity, mobilizations, and claims-making of these organizations cannot simply be reduced to being clients of welfare programs, such interest groups are closely connected to the welfare state and strive for both recognition and redistribution of resources through particular welfare programs such as programs for gender equality, disability, and elder care (Feltenius 2008, 30).

It has been argued (e.g., Feltenius 2008) that client interest groups have a weaker position vis-à-vis the state than so-called producer interest groups (employers' organizations and trade unions). While producer interest groups can deploy strategies (e.g., lockouts or strikes) that might directly threaten the economic basis of the state, the state can ignore client interests to a greater extent because these groups are dependent on the state's ability and willingness to recognize their claims. Lack of access at the national level might make client interest groups more eager to seek influence at the European level to compensate for their lack of domestic influence (cf. Klüver $2010,181)$. However, many Swedish client groups have historically had relatively good access to policymaking. Organizations representing, for example, the disabled, pensioners, and immigrants have been able to establish longterm relationships and exert at least some influence on national policy (Aytar 2007; Feltenius 2008; Markström 2003). This corporatist tradition in the Swedish welfare state might disincentivize Swedish CSOs to Europeanize. 
We also include organizations representing more diffuse interests, including (7) humanitarian organizations, (8) social service organizations, and (9) religious associations and congregations. Compared to organizations representing specific interests, humanitarian organizations do not seek to represent specific groups. While the former build on self-organization, the main task of the latter is to organize activities and perform services for others (Lundström and Svedberg 2003; Meeuwisse and Sunesson 1998). Humanitarian organizations, such as the Red Cross and Save the Children, often provide aid and help for vulnerable groups both in Sweden and abroad. Social service organizations instead provide specific social welfare services (e.g., social care and child care) on the basis of a nonprofit organizational logic, often on behalf of and funded by the public sector. Many of these organizations define themselves as cooperatives. These types of associations are a relatively new phenomenon in the Swedish organizational landscape, and many are a product of the deregulation of the welfare service provision system over the past two decades. Religious associations and congregations are usually engaged in social welfare issues regardless of their denomination. Since the separation of the church from the state in 2000, organizations belonging to the Church of Sweden (the state church since the Reformation) also count as CSOs. They are traditionally engaged in social welfare issues through diaconal activities (Linde 2010), but they are also present in the public debate as a critical theological voice (Bäckström 2014), for example regarding issues such as poverty, immigration, and homelessness (Linde and Scaramuzzino 2018).

The tenth and last organizational type is (10) political parties. Like the others they are membership-based and separated from the state. Parties, however, have specific functions that distinguish them from other organizations in civil society. For instance, they have a channeling function and act as a bidirectional link between citizens and decision-makers. Political parties thus not only aggregate interest, but also provide the elected assemblies with the representatives that make political decisions at different administrative levels, from the local level to the level of the EU (Dahl 2011). While many parties have originated from social movements, and some continue to entertain their bonds with specific movement constituencies, the overall tendency is that parties having such roots also increasingly become the target for various social movements' efforts to influence their strategies and decisions (della Porta and Diani 2006). In this sense, political parties can be seen as both civil society actors and as part of the institutional framework that many CSOs might try to influence.

While the representative function of political parties in the parliamentary system is seldom questioned, the role that interest organizations play in the political system is a more debated topic. The Swedish system has 
developed from a classical corporative system, with formal channels for political influence by selected legitimate organizations, to a more pluralistic system in which organized interests also seek influence through advocacy and lobbying (Naurin 2001; Svallfors 2015). We argue that including political parties as an organizational type in the analysis might give interesting insights into the processes of Europeanization, especially when compared to interest organizations.

\section{The Organizations: An Overview}

In this chapter we compare ten types of CSOs based on survey data from 1,786 CSOs. We excluded 889 cases from our original sample because they did not fall into the ten organizational types, e.g., cultural and sports associations. Even if they represent different kinds of interests, focus on different policy issues, and have different positions in the policymaking process, these organizations all have a common interest in social welfare issues. The number of organizations on which the analysis is based is presented in table 3.1.

Before addressing the Europeanization of Swedish CSOs, it is important to present some basic characteristics for the CSOs surveyed (see table 3.2). Some of these characteristics have been proven to be relevant for explaining CSOs' different degrees of Europeanization in previous research on interest organizations (e.g., Beyers 2002, 2004, 2008; Beyers and Kerremans 2007; Bouwen 2002; Chalmers 2013; Dür and Mateo 2012; Klüver 2010; Scaramuzzino and Wennerhag 2015), including their representativeness in terms of membership base and their resources in terms of employed staff. Other characteristics that can be seen in the table are the organizations'

\section{Table 3.1. Ten Types of Organizations Analyzed in the Chapter}

\begin{tabular}{llr}
\hline Type of interests & Organizational type & N. \\
\hline Organizations representing & Disability organizations & 167 \\
specific interests & Temperance and drug users' organizations & 72 \\
& Trade unions & 110 \\
& Victim support organizations & 56 \\
& Women's organizations & 90 \\
& Other interest organizations for social groups & 148 \\
Organizations representing & Humanitarian organizations & 450 \\
diffuse interests & Social service organizations & 78 \\
Political parties & Religious associations and congregations & 533 \\
& Political parties & 82 \\
\hline
\end{tabular}




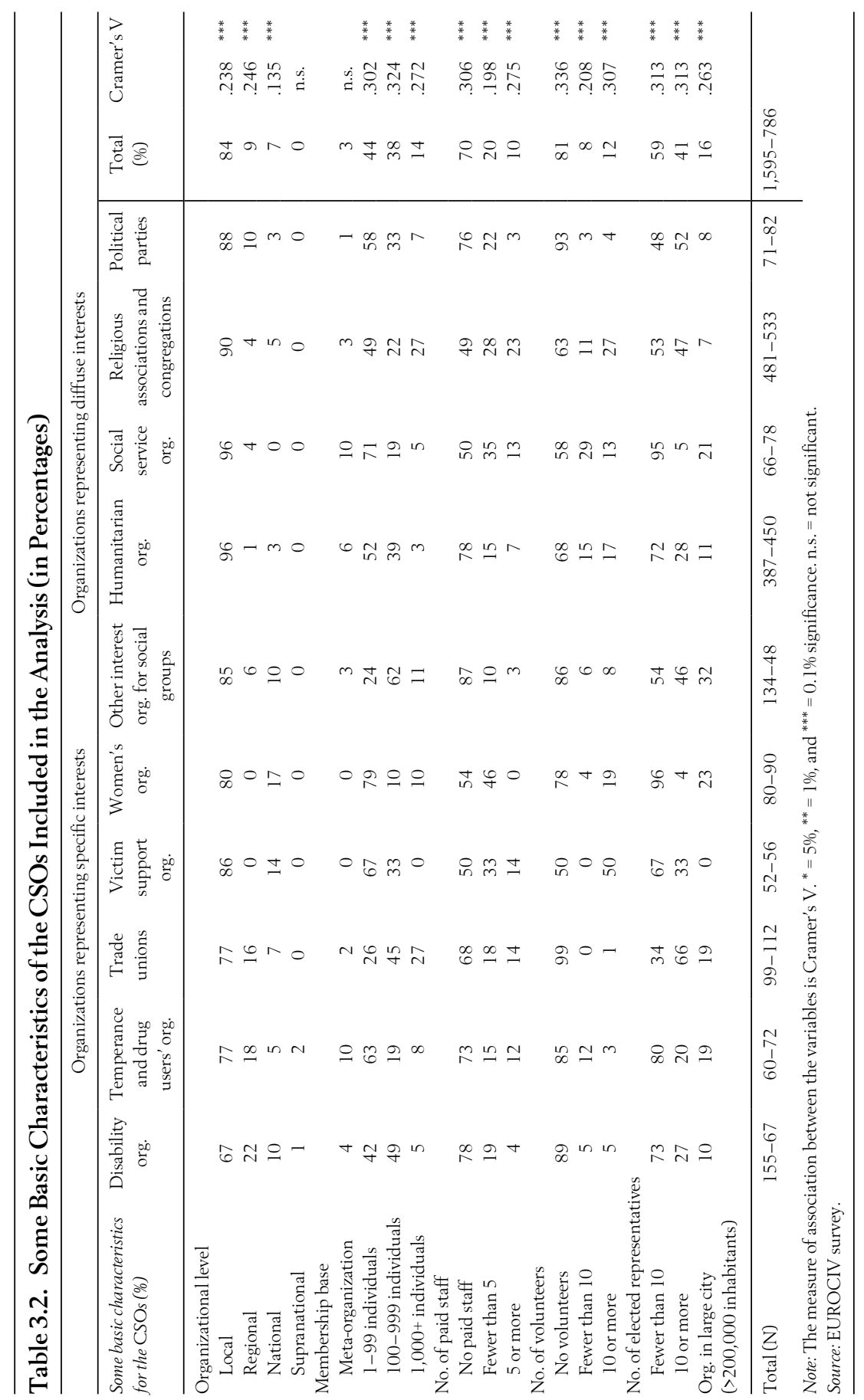


geographic level (i.e., the geographic level that the CSO claims is its primary area for members and activities) and whether the organization is registered in a large city. The table also gives an idea of the scope of individual members, staff, volunteers, and elected representatives who are involved in these organizations.

Most of the CSOs that are analyzed are locally based ( 84 percent). This is particularly true for humanitarian, social service, and religious organizations. Some types of organizations representing specific interests often have the regional level as their primary geographic domain (especially trade unions and temperance and disability organizations). Other types of CSOs have a somewhat larger share of organizations primarily working at the national level (especially victim support and women's organizations). Table 3.2 also shows that most of the organizations included are individualmembership based, and meta-organizations or umbrella organizations represent only 3 percent of the CSOs. More than half of the organizations have one hundred members or more, and the membership bases of the different $\mathrm{CSO}$ types differ significantly. In particular it is notable that trade unions and religious organizations include a large share (28 percent) of associations with one thousand or more members. Most organizations (70 percent) are not professionalized and lack employed staff. The types of CSOs that most often have employed staff are women's, victim support, and social service organizations together with religious associations and congregations. Most CSOs ( 81 percent) do not have any nonmembers as voluteers. Here we find that victim support and the three types of organizations representing diffuse interests tend to have more volunteers than the rest. A majority of the CSOs (59 percent) have fewer than ten elected representatives, and almost all women's and social service organizations have few elected representatives. Finally, a small share of the organizations (16 percent) are registered in large cities with more than two hundred thousand inhabitants, which is consistent with the share of the national population that lives in the three Swedish cities that have that many inhabitants ( 18 percent). Some of the characteristics presented here are consistent with the results of previous survey studies of Swedish organized civil society. In particular, the relatively large individual membership base and the low level of professionalization have been highlighted in cross-national comparative studies of civil society (Salamon et al. 2004).

These differences should be kept in mind as we proceed with the analysis of the data because they might provide explanations for some of the differences that will be presented in the bivariate analysis. Chapter 4 will assess whether some of these factors actually influence the level of Europeanization of Swedish CSOs. 


\section{What Motives Do Swedish CSOs Have to Europeanize?}

This section deals with CSOs' motives to Europeanize and with the perceived challenges and obstacles connected with Europeanization.

Influencing policy is an important driving factor behind CSOs addressing the European level. However, organizations might have many potential motives for influencing the EU or influencing policies involving the European level. And even though all might use the structures of the EU, the intended targets for the CSOs' claims and pressures might differ. It does not even need to be the EU itself that is the final addressee of the CSOs' efforts; the EU can also be used as a vehicle for getting specific member states to change their policies, which can include the CSOs' own countries.

In table 3.3 we highlight some motives that correspond to these different approaches to using the EU for changing policies. They all refer to the regulatory functions of the EU. The figures show to what degree CSOs see different types of EU-related influence as very or somewhat important for their own organizations.

The table suggests that there is no overall trade-off between the different motives to Europeanize, and certain types of CSOs (e.g., trade unions) are more likely to deem all four motives as important compared to other types of CSOs (e.g., humanitarian organizations), which are less likely to deem all four motives as important (see Johansson, Scaramuzzino, and Wennerhag 2018). Among the different reasons for seeking to influence the EU level, the one that most CSOs perceived as important is to influence the policies of the EU itself (23 percent) followed by influencing other countries to adopt Swedish policies within the interest areas of the organization (21 percent). Almost as common ( 16 percent) is that the CSOs want the EU to put pressure on Sweden in order to change policies within the organization's main interest areas.

We also find interesting differences among the different CSO types. While temperance and drug users' organizations and trade unions find it most important to convince other countries to adopt the same policies as Sweden's, disability organizations see it as just as important to convince the EU to put pressure on Sweden. Such differences clearly illustrate that the agendas of different CSO types can be more or less close to their own national government's political agenda. Trade unions and temperance organizations have long been central coactors in shaping the dominant Swedish policies in their own areas of interest; it seems logical that these organizations see the Swedish government as the prime vehicle for spreading their policies to other EU member states. Some organizations might in fact have larger stakes in EU policies for the purpose of maintaining and/or exporting a particular 


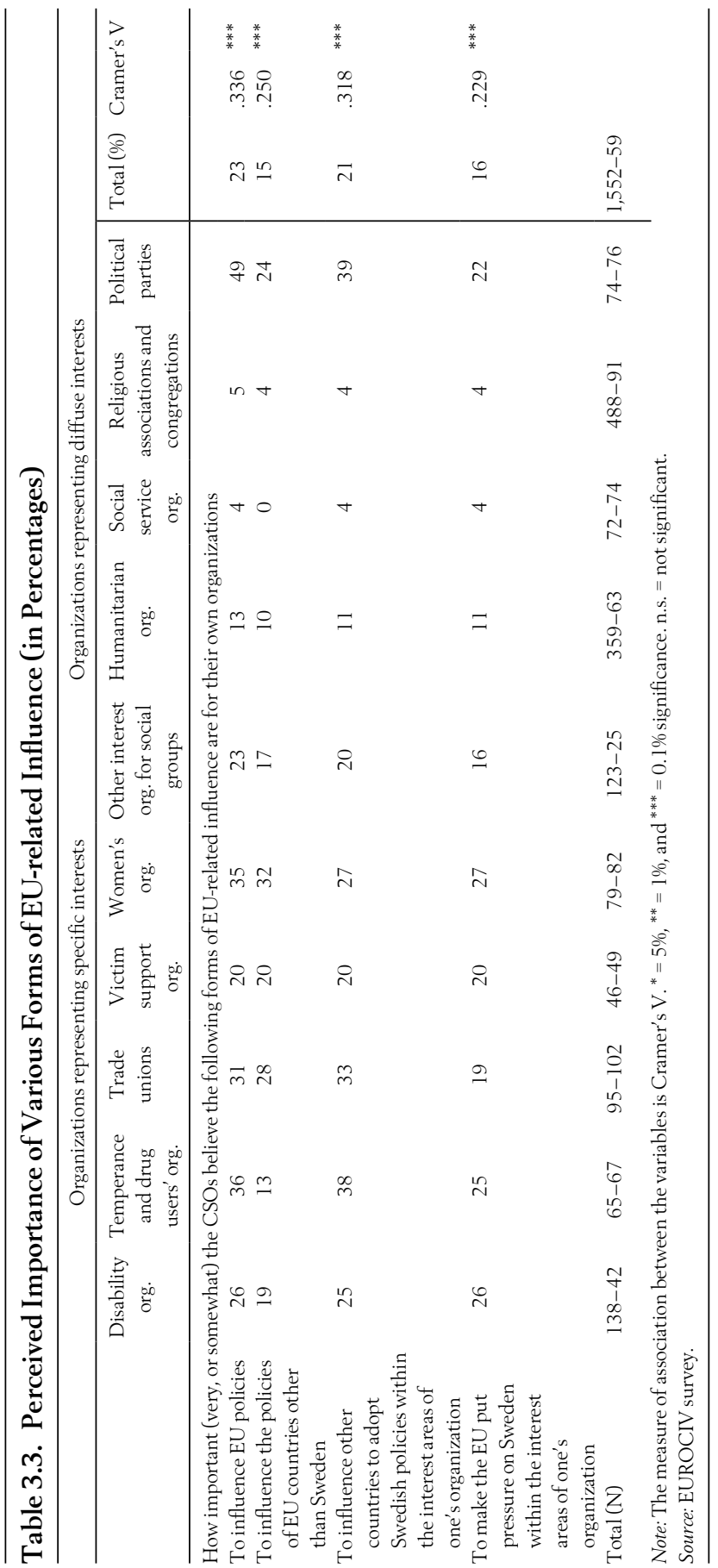

This open access library edition is supported by the University of Lund. Not for resale. 
model for interpreting and solving issues such as workers' rights or alcohol and drugs that they have developed domestically. Behind this might be a concern that EU harmonization might lead to a loosening of the specific Swedish model. This is consistent with Beyers and Kerremans' (2012) argument that the issue-specific context in which interest groups develop their political strategies can be an incentive to address other levels of government than the domestic level, particularly for groups that organize around issues that will be significantly affected by policy changes (see also Johansson, Scaramuzzino, and Wennerhag 2018).

\section{Obstacles for Organizing and Acting at the EU Level}

Being present and active at the EU level is often achieved through membership in networks at the European level, as shown by Johansson and Kalm in chapter 2 of this volume. While offering certain opportunities, organizational Europeanization can also create challenges for CSOs. Table 3.4 shows the CSOs' perceived problems of being a member of a European network.

A majority of the organizations that are members of networks at the European level state that they lack the time and resources that are needed to be engaged at their preferred level (66 percent) and that EU-level issues are too complex (61 percent). This shows that both organizational resources and knowledge are required to Europeanize through meta-organizations and networks. Lack of interest among the CSOs' members is also stated by almost half of the organizations (46 percent) as a problem when being a member of a network at the European level. More than one in three organizations also state that the EU does not directly affect the issues that the organizations deal with. The control exercised by the EU is stated by one in four CSOs as a problem connected with membership in European networks, suggesting a risk of becoming more of an object to than a subject in Europeanization. Obstacles are most strongly perceived among political parties, followed by organizations representing specific interests and by organizations representing diffuse interests. The fact that political parties and to some extent also organizations representing specific interest are more voice oriented (compared to humanitarian and service organizations) might explain why they to a larger extent question both the relevance of the EU and the ideology and values propagated by other organizations. A perceived clash between Swedish CSOs' norms and values with those propagated by other organizations from other national contexts, for instance on drug use or prostitution (see chapter 9), are in fact more likely for these organizations.

One possible obstacle for Europeanizing suggested above might be that Swedish CSOs do not perceive the European level as relevant and might 


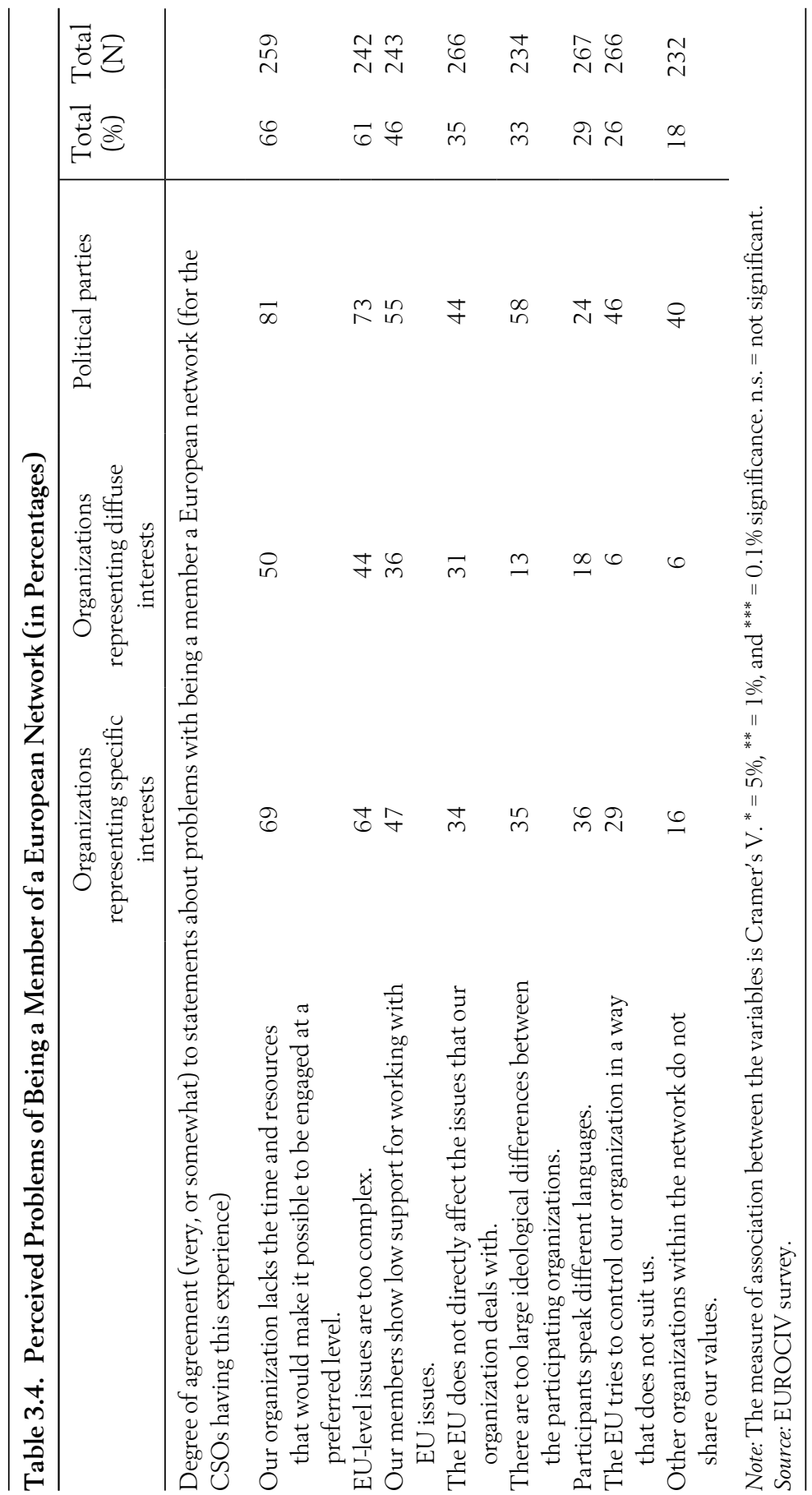

This open access library edition is supported by the University of Lund. Not for resale. 
hence lack the motives to "go European" (cf. Scaramuzzino and Wennerhag 2015). To investigate this further, we will turn our gaze to the CSOs' general perception of the relevance of the European level for the problems and issues with which they work. We can understand such statements as expressions of the perceived political opportunities that the EU offers and hence as expressions of regulatory Europeanization.

Table 3.5 presents (in the first part) the degree to which Swedish CSOs think that the European level is important for solving the issues and problems that they work with and (in the second part) the perceived relevance of other geographic/administrative levels. The second part of the table presents the percentages of organizations that perceive the level as at all relevant, thus including those that deem it very, somewhat, and not very important (excluding those deeming it not at all important).

Table 3.5 shows that only one in ten organizations perceives the European level as very important, while 65 percent deem the European level as not at all important. Compared to other geographical levels, the European level is seen as one of the least relevant. While a large majority of the CSOs perceive the domestic (local and national) levels as important, only one in three organizations considers the three supranational levels (Nordic, European, and international) as relevant. The fact that the Nordic, European, and international levels are regarded important by only a minority of CSOs also indicates that the EU level is merely perceived as one among other supranational levels of decision-making. Given the fact that the EU has far more political power than Nordic and international decision-making bodies, this finding can be seen as a bit surprising and might mirror a general Swedish skepticism toward the EU, as described in the introductory chapter.

\section{How Do Swedish CSOs Europeanize?}

Swedish CSOs might Europeanize in different ways. In this section we address three types of Europeanization: regulatory, organizational, and financial. Regulatory Europeanization is understood as an expression of political activity at the European level, organizational as membership in European networks and umbrella organizations, and financial as economic support from EU institutions.

\section{Regulatory Europeanization}

The extent to which CSOs have tried to influence politicians or officials at the European level of decision-making regarding issues that are central for 


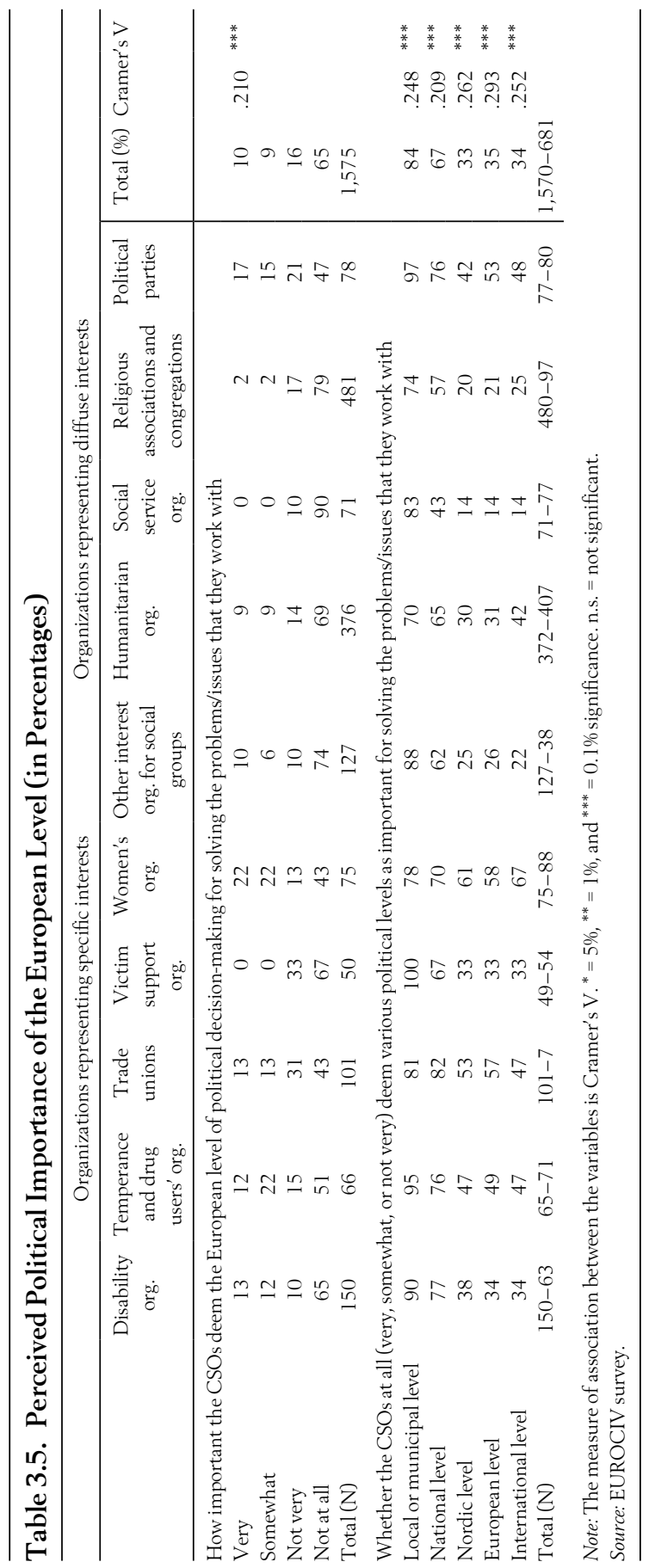

This open access library edition is supported by the University of Lund. Not for resale. 
the organization is used as a measure of regulatory Europeanization. These results are presented in table 3.6, which shows whether the organizations had often, sometimes, rarely, or never tried to influence politicians and officials on the European level. In the second part of the table we compare the extent to which the CSOs have at all (often, sometimes, or rarely) addressed the European level compared with the local, national, Nordic, and international levels.

Eighty percent of Swedish CSOs state that they have never tried to influence politicians or officials at the European level of decision-making, while fewer than 10 percent of the organizations claim to have done so sometimes or often. In contrast, 80 percent of the CSOs say that they have tried to influence decision-makers at the local level, and half have attempted to have an influence on the national level. The organizations are thus not only primarily locally based (as was shown in table 3.2), but they also foremost try to influence local politics.

The number of CSOs that have tried to influence politicians and officials at the supranational levels (Nordic, European, or international) are quite small, and involves between 18 and 20 percent of the organizations. There does not seem to be any trade-off between the CSOs' efforts to address different levels of political decision-making. Instead, the types of organizations that are more active on one level are also more active on other levels. Political parties in particular stand out as being most active at all political levels. It is also notable that organizations representing specific interests in general are more active at most political levels unlike organizations representing diffuse interests. This confirms political parties' and specific interest organizations' stronger voice orientation, as mentioned above.

These results also show that CSOs do not restrict themselves to the European level when it comes to influencing supranational forms of political decision-making, but also try to influence the Nordic and the international levels. However, the degree to which they try to influence these levels is quite small.

There are also other strategies that CSOs can use if they want to influence EU policies. These involve not only direct contacts with the representatives of the political system, but also include using one's transnational CSO networks, engaging external consultants (e.g., public relations bureaus), or staging demonstrations. Two distinct approaches that are often used by CSOs are externalization, which implies targeting EU institutions to put pressure on the national government, and domestication, which means targeting one's own national government to engage in negotiations at the European level in order to provide better opportunities for the country or to make general changes in EU policies (della Porta 2013). Table 3.7 shows the degree to which the CSOs have used different strategies to influence EU 


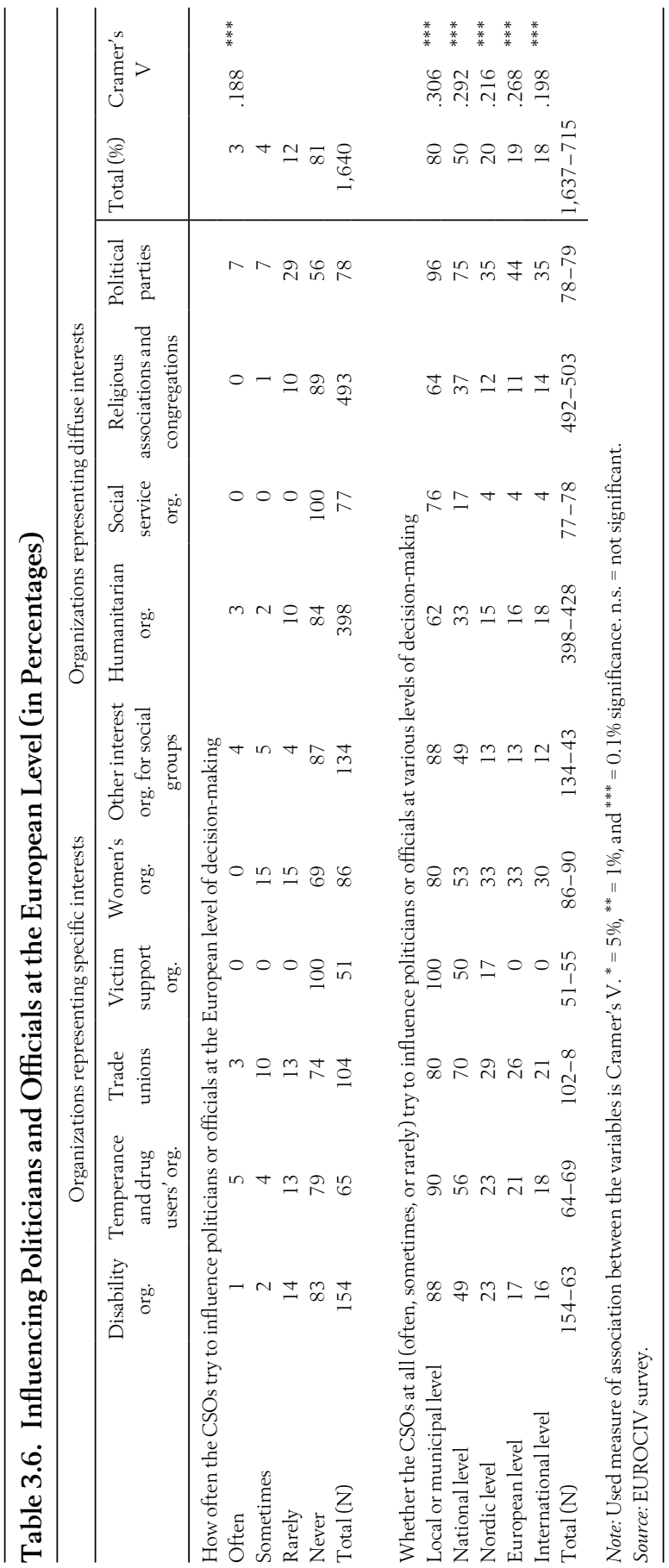

This open access library edition is supported by the University of Lund. Not for resale. 
policies, ranging from direct contacts with representatives of institutionalized politics to using extra-parliamentarian repertories of action such as demonstrations.

Table 3.7 indicates that the most common strategy to influence EU policies is to contact Swedish authorities or Swedish political parties. This strategy is adopted by 36 percent of the CSOs, while only half as many ( 18 percent) have contacted members of the European Parliament (MEPs). This also illustrates that what della Porta (2013) labels as domestication is the most common strategy used for influencing EU policies. CSOs' demands for political or regulatory changes in EU policies are thus usually mediated by domestic actors of one's own country (see also Johansson, Scaramuzzino, and Wennerhag 2018).

Apart from the use of domestic politicians and authorities, table 3.7 shows that demonstrations, international umbrella organizations, and direct contacts with MEPs have been used by around 20 percent of the $\mathrm{CSO}$ as a means to influence $\mathrm{EU}$ policies. The staging of demonstrations is most common among trade unions and political parties. The use of both international and European umbrella organizations for the purpose of influencing EU policies furthermore suggests that internationalization and Europeanization are closely interlinked and that these processes might in fact strengthen each other.

The types of CSOs that are known to be more politically active (political parties and organizations representing specific interests, as shown in table 3.6) also use all types of strategies to a greater degree than organizations representing diffuse interests. These results suggest that there is no direct trade-off between different types of strategies such as access, information, and protest (see Beyers 2004 for a typology), which our analysis of political strategies at the national level also showed (Scaramuzzino and Scaramuzzino 2015; Scaramuzzino and Wennerhag 2013).

All in all, regulatory Europeanization seems to involve a minority of Swedish CSOs when we look at their activities at the European level. However, when we include the use of channels for political influence at the national level for the purpose of influencing EU policy (domestication), we find that more than a third of Swedish CSOs have Europeanized to some extent. Political parties in particular are active in this sense, but it is also notable that almost half of the trade unions and temperance organizations have contacted national politicians in an attempt to influence EU policies.

In order to better understand the figures of table 3.7, we also need to look at what strategies are used for influencing politics in Sweden. These are shown in table 3.8 .

Table 3.8 indicates that by far the most-used strategies to influence politics in Sweden are to contact politicians (45 percent) or public officials (37 


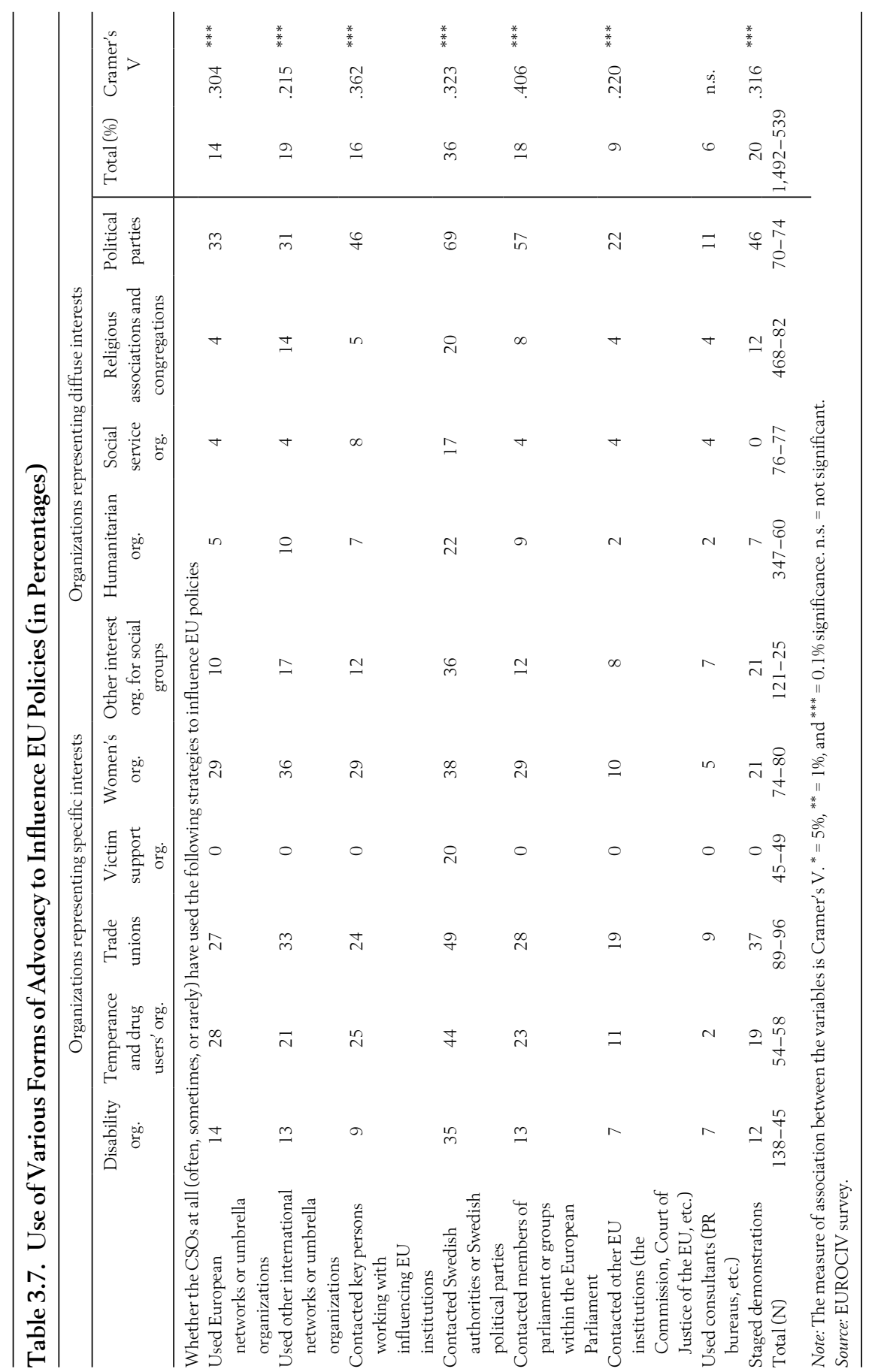

This open access library edition is supported by the University of Lund. Not for resale. 


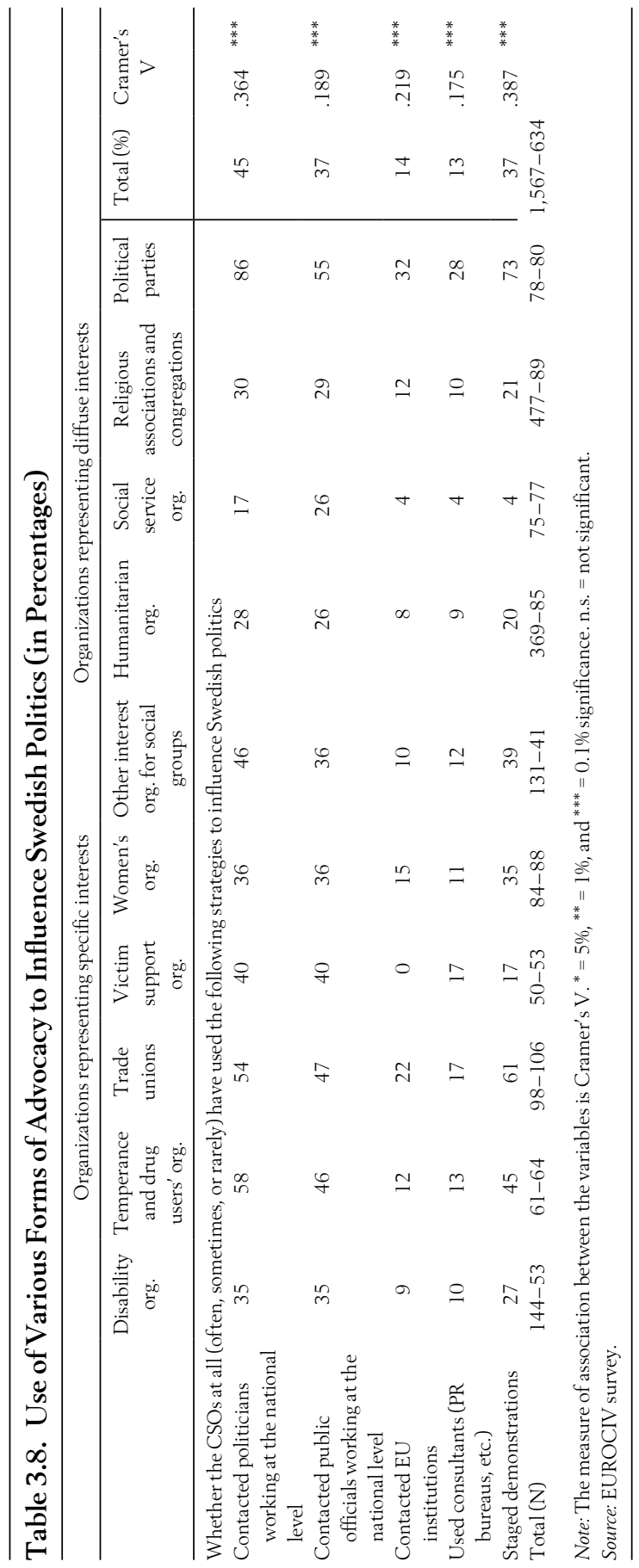

This open access library edition is supported by the University of Lund. Not for resale. 
percent) working at the national level and to stage demonstrations (37 percent). Only 14 percent of the CSOs say that they have contacted EU institutions in order to influence Swedish politics. This externalization strategy (della Porta 2013) is most common among trade unions (22 percent) and political parties (32 percent), but women's organizations also use it to some extent (15 percent). Demonstrations as a way to influence Swedish politics are in particular used by political parties and trade unions and to some degree also by temperance and drug users' organizations. Most types of CSOs seem to favor inside lobbying.

When comparing the results shown in table 3.7 and table 3.8, one finds that the share of CSOs that have tried to influence EU policies in general is lower (between 6 and 36 percent depending on the strategy) than the share that have tried to influence Swedish politics (between 13 and 45 percent). This difference should, however, not be overemphasized. Even if only around 20 percent of the CSOs have tried to influence MEPs, it is still no more than 45 percent that have tried to influence Swedish politicians working on the national level. In both cases the majority has not tried to influence politics at all. These results are consistent with the data presented in table 3.6.

\section{Organizational Europeanization}

Organizational Europeanization was measured by asking which networks, federations, or umbrella organizations at different levels the organizations were direct members of; the results are shown in table 3.9.

Considering the high percentage of locally based organizations in our sample, it is remarkable that 12 percent of the Swedish CSOs are members of networks or umbrella organizations at the European level, and hence are Europeanized from an organizational point of view. The CSOs that are the most Europeanized in this sense are trade unions, temperance and drug users' organizations, and political parties. But compared to other geographical levels, affiliations at the European and international levels are much rarer. An exception to the rule is humanitarian organizations that quite often are members of international federations and networks; those memberships are likely connected to their activities concerning international aid.

By far the most common level when it comes to affiliation is the national level, which is perhaps not that surprising considering that 84 percent of the organizations in our sample are local organizations. The Swedish corporative structure has in fact encouraged interest groups to organize at the national level through federations for representational purposes and for participation in consultative bodies such as forums and councils, e.g., where CSOs have been invited by public authorities to, among other things, comment on 


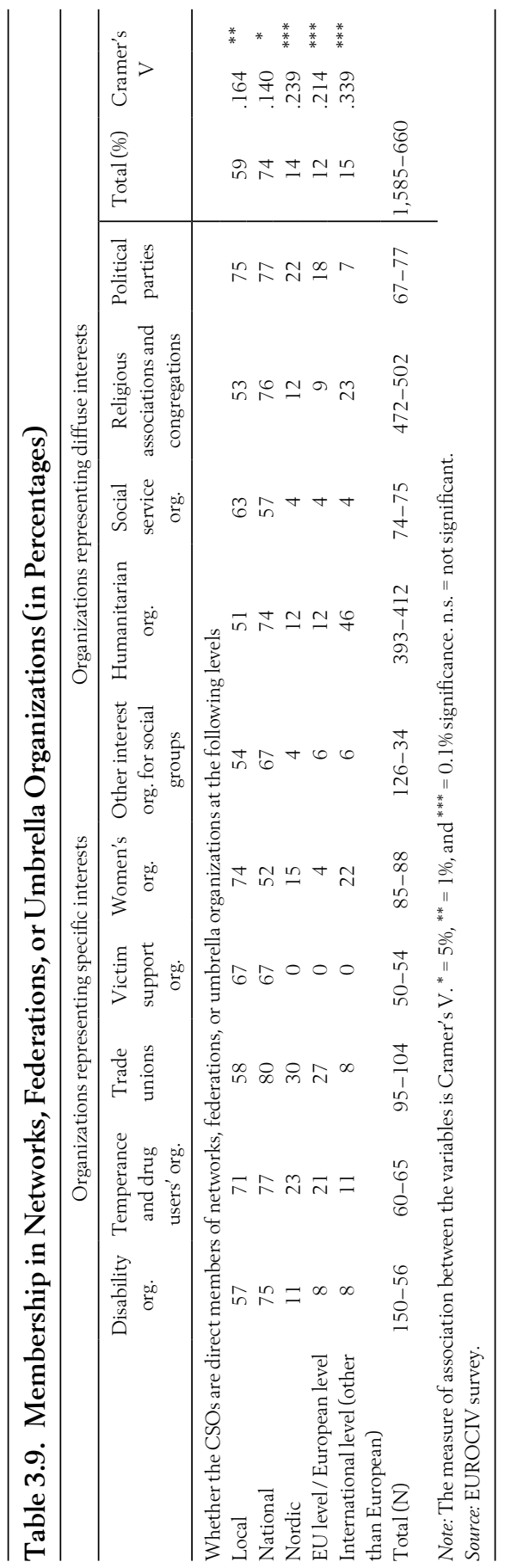

This open access library edition is supported by the University of Lund. Not for resale. 
relevant legislative proposals, e.g., in disability policy and integration policy (cf. Aytar 2007; Feltenius 2008).

More than half of the organizations are also members of metaorganizations or networks at the local level, which shows that also on the local level there is a need for coordination between CSOs.

\section{Financial Europeanization}

Financial Europeanization was measured by addressing the importance of different sources of income for the budget of the organization. The sources covered funding from EU institutions (European social funds, European regional funds, etc.) and other sources of funding, both public and private. Table 3.10 shows the share of the organizations that responded that these sources of income are at all (often, sometimes, or rarely) relevant, and leaves out those explicitly stating that the specific source is not a source of funding for them.

Public funding is far from being relevant for all Swedish CSOs despite the fact that the Swedish public sector has an extensive system of funding targeting CSOs and includes funding at the municipal, regional, and national levels based on both organizational grants and project-based grants (cf. Danielson, Zetterberg, and Amnå 2009). Support from local municipalities seems in fact to be relevant just for half of the CSOs, and support from the state for one in four. However, while trade unions are in principle not at all dependent on public funding, other organizations representing specific interests-such as victim support, women's, temperance, and disability organizations-are to a much greater degree dependent on public funding (mostly from the local municipalities, and in some cases also from the state). Political parties are also highly dependent on public funding.

Overall, funding through members' fees is by far the most frequently mentioned ( 83 percent) source of income, followed by private donations and sales of goods and services. Funding from EU institutions seems to be relevant only for a small minority of the organizations ( 8 percent). One can thus conclude that financial Europeanization is not a widespread phenomenon among CSOs in Sweden. Victim support organizations stand out as the exception: 17 percent of them deem EU funding as relevant for their organizations' budget.

\section{Participating in Activities at the European Level}

Participating in activities at the European level can also be an expression of Europeanization, which might be linked to each of the types of 


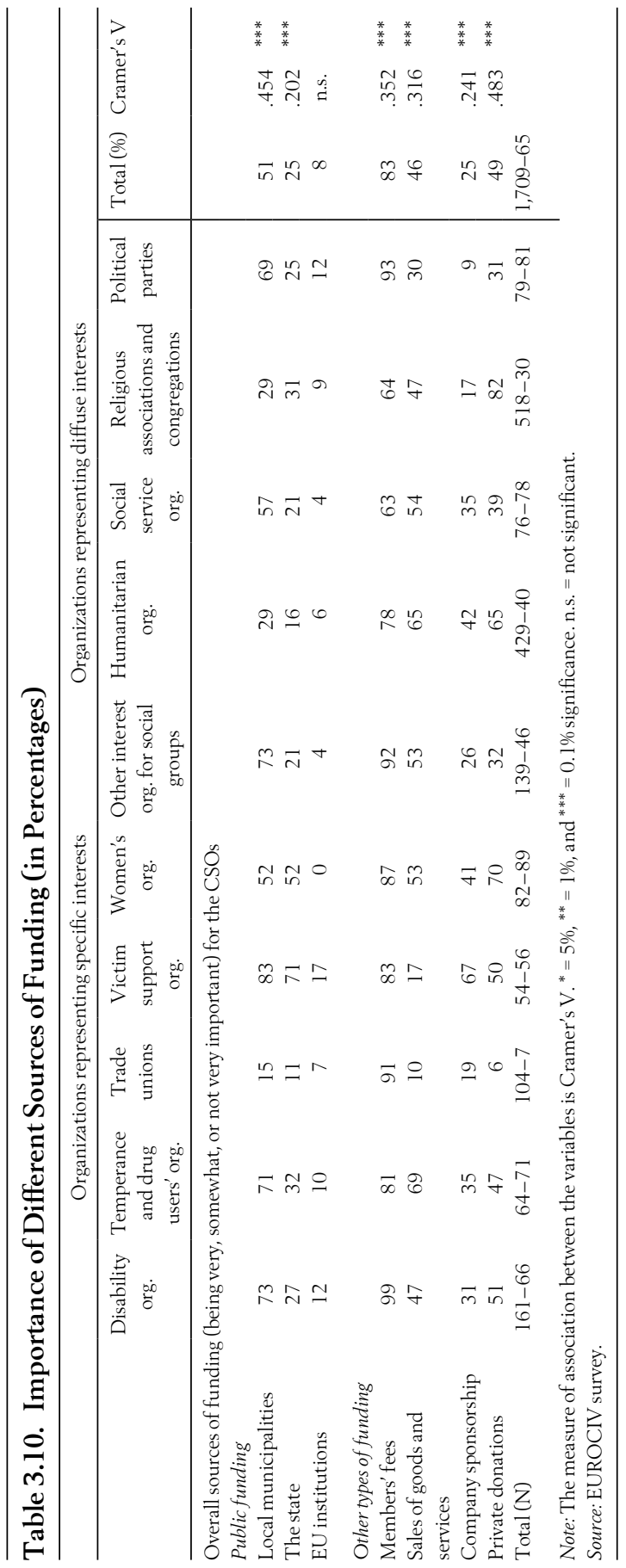

This open access library edition is supported by the University of Lund. Not for resale. 
Europeanization described above. It might be part of the CSOs' political activities, their membership in a network, or an EU-funded project. It might also relate to more than one type of Europeanization. Table 3.11 shows the extent to which Swedish CSOs state that they at all (often, sometimes, or rarely) have participated in different activities at the European level.

The most common activity is to participate in meetings and conferences held by organizations that are active at the EU level. The fact that as many as 28 percent of Swedish CSOs state that they at all participate in such meetings shows that the level of participation in such activities is much higher (more than double) than the level of affiliation to European networks (12 percent). Participation in campaigns led by organizations that are active abroad is also a relatively common activity (which could include contacts with organizations principally active at the EU level). The types of organizations reporting this type of activity are in most cases those that are affiliated with EU-level networks to a high degree (political parties, trade unions, and temperance and drug users' organizations). Even though they showed a low level of affiliation in European networks, women's organizations also reported a rather high level of participation in such campaigns. The women's organizations also seem to participate in other types of network-based activities at the EU level more often than many other organizations.

\section{Perceived Consequences of Europeanization}

\section{Political Influence}

While one can assume that CSOs that try to influence decision-making want these efforts to result in actual changes in policies and political decisions, it is not obvious to what degree this desired outcome is obtained. In order to get a better picture of the perceived effectiveness of the CSOs' efforts to influence politics at the European level, we will discuss the extent to which the organizations perceive that their efforts have led to concrete changes. We understand this as the perceived consequences of regulatory Europeanization; the results are presented in table 3.12.

The presented results are based only on the CSOs that responded positively to the previous questions about whether they have tried to influence politics at the European level. Only 20 percent of these CSOs often or sometimes had experienced that their efforts led to concrete changes, but a more positive interpretation is that more than half of the organizations (62 percent) reported some kind of political impact, even if it happened rarely. It can be relevant to compare these figures for the European level with the answers to the same question regarding other administrative levels (figures 


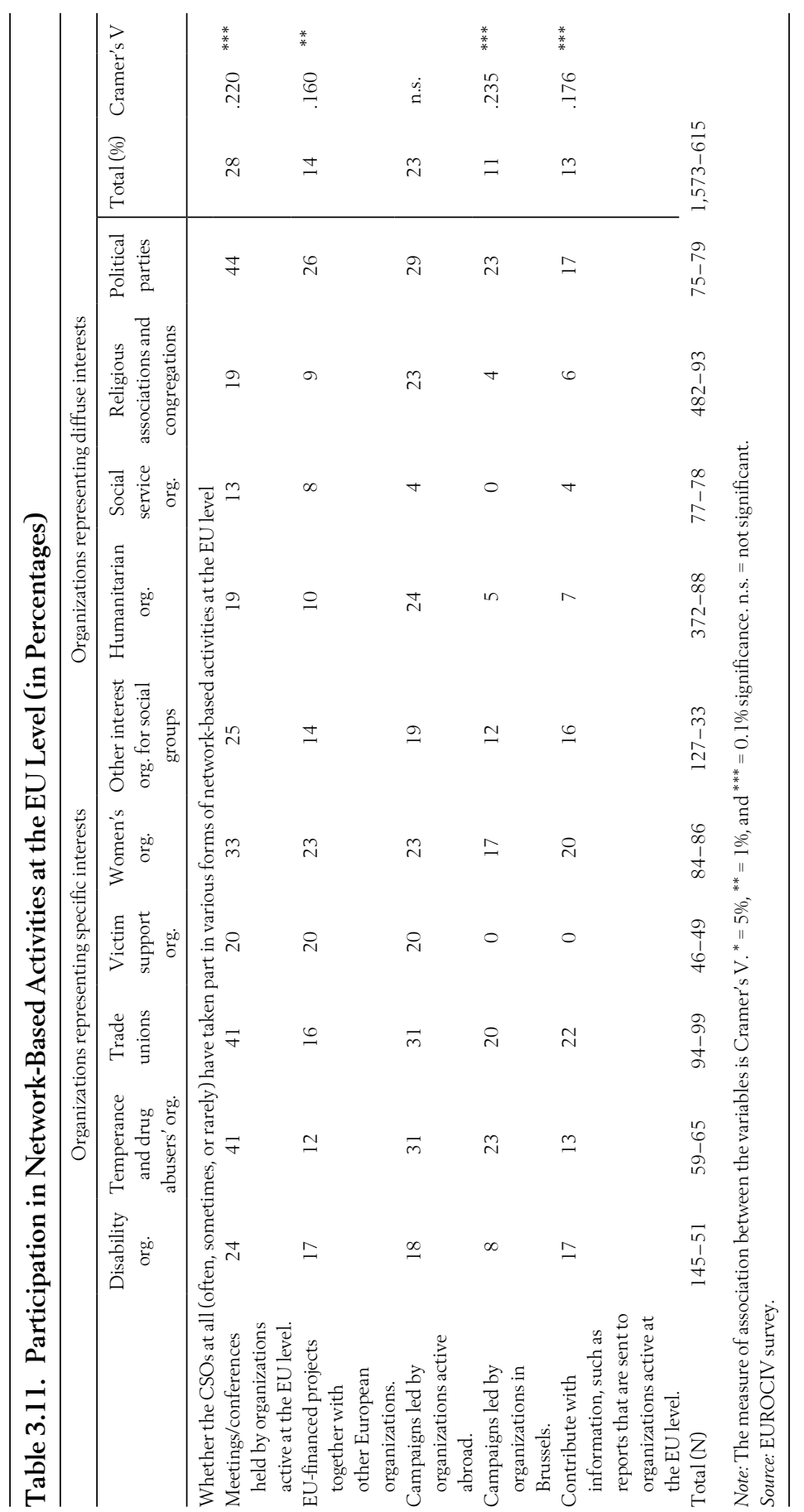

This open access library edition is supported by the University of Lund. Not for resale. 


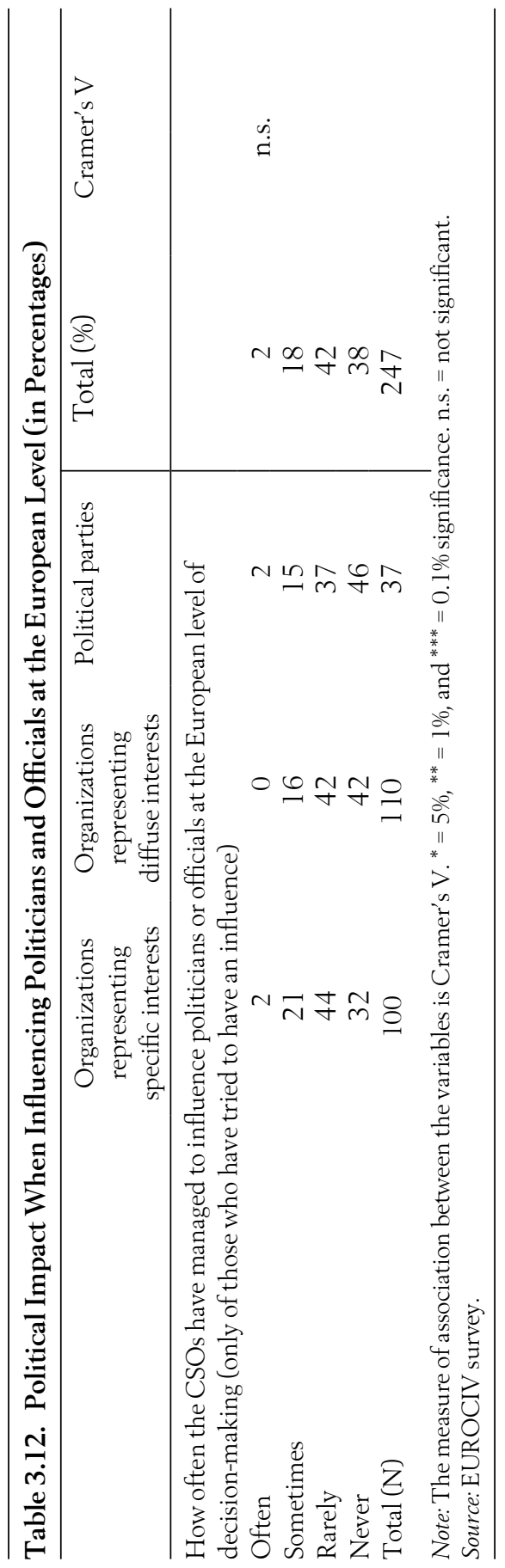

This open access library edition is supported by the University of Lund. Not for resale. 
not presented in the table). A large majority ( 87 percent) of the CSOs stated that they had achieved some influence at the local level. At the national level, the corresponding figure was 76 percent, and for both the Nordic and the international levels the corresponding figure was 62 percent. These results show that Swedish CSOs are not only more active in influencing decision-making at the domestic levels (local and national), but they are also more likely to perceive that they wield some influence on these levels compared to the European level. Given the fact that it is perceived as more effective for the CSOs to address the national level instead of the European level, it seems reasonable that those CSOs more often address the national level for influencing EU policies (as shown above). These results suggest, however, that even if CSOs are active at the European level to a lesser degree than they are at the domestic levels, their efforts in addressing the European level in most cases are perceived as producing at least some effects in terms of political influence.

\section{Effects of Organizational Affiliations}

We would also like to address the perceived results or outcomes from being affiliated with a network, federation, or umbrella organization at the European level $(\mathrm{N}=271-93)$. The most common answer concerning the results of such affiliations was that the organizations thought that they had enabled them to be well informed about EU policies (38 percent). This is most evident for political parties ( 71 percent), but quite a high share of the organizations representing specific interests also mentioned this ( 40 percent). The perceived complexity of EU-level issues, while being perceived as an obstacle for Europeanize as shown above (see table 3.3), is thus also partly overcome through membership in networks or organizations at the EU level. The fact that some organizations found that membership in European networks and umbrella organizations helped them to keep well informed about EU policies suggests that, once the complexity threshold is overcome, membership can actually be an important source of information about what is going on in Brussels. Twenty-eight percent also reported that their organizations' credibility toward public actors and other organizations had been strengthened by these affiliations. Increased legitimacy thus seems to be one of the outcomes of membership in European umbrella organizations and networks.

When it comes to organizational Europeanization, a larger share of CSOs highlight the challenges of participating compared to those reporting positive effects or outcomes of membership. It seems therefore that active participation among CSOs that are formal members of networks and umbrella organizations at the European level is rare, which suggests a more passive 
membership. Thus the CSOs in our sample tend to become more objects to than subjects in organizational Europeanization.

\section{Mobilizing Resources}

To be able to access financial resources at the European level, CSOs often have to apply for funding from one of the many EU programs (see, e.g., the discussion on the ESF council in chapter 6). Table 3.13 shows the percentages of organizations that answered that they had often, sometimes, rarely, or never applied for EU funding.

Only 10 percent of the organizations had applied for EU funding, and among these victim support, women's, and social service organizations stand out. The relatively low degree of public funding among Swedish CSOs should, however, be kept in mind. Our survey furthermore shows a quite high level of success among the CSOs that had applied for funding. Only 29 percent of the organizations stated that they had never received the funding they had applied for $(\mathrm{N}=201)$.

The consequences of this financial Europeanization also need to be addressed. A large majority (87 percent) of the CSOs that had applied for funding $(\mathrm{N}=196-200)$ reported that applying for funding required a lot of resources such as knowledge, time, and staff. This shows a high threshold for accessing EU resources, which also has been suggested in previous research about EU funding of Swedish CSOs (Scaramuzzino et al. 2010; Scaramuzzino 2012; see also chapter 6 of this volume). The results also show that half of the CSOs that had applied for EU funding adapted their activities to increase the possibilities of accessing such funds. This seems to imply that EU funding influences organizational behavior, thus making Swedish CSOs more object to than subject in financial Europeanization. But even though many organizations acknowledge that they had adapted their activities to increase their chances of getting funding, only 8 percent perceived that the funding had led to changes in the goals of the organization. A possible interpretation is that such adaptations were merely cosmetic and did not involve the mission or core values of the organizations.

One in three CSOs stated that EU funding had made it possible for them to initiate new projects and activities that they otherwise would not have been able to start. This suggests that EU funding represents an alternative to other sources of funding, which opens up new opportunities. However, the fact that only 6 percent stated that EU funding had made them less dependent on economic support from the state and the local municipality suggests that such funding is more a complement than an alternative to domestic public funding. The results also show that not only applying for EU funding 


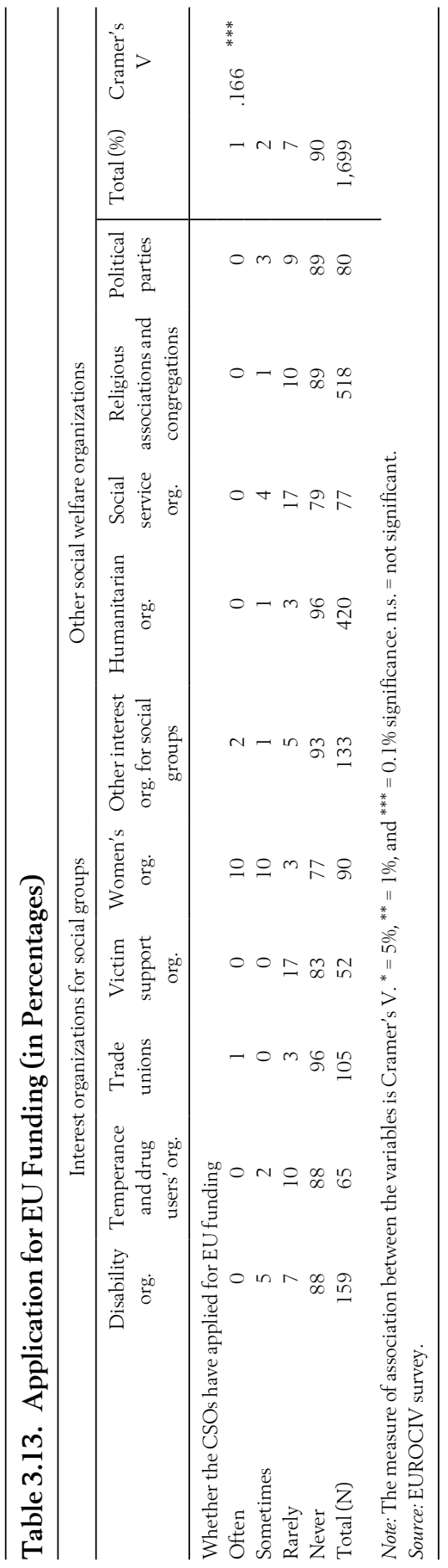

This open access library edition is supported by the University of Lund. Not for resale. 
requires a lot of resources, but also the administration of received funds requires significant resources, which is something that more than half of the CSOs stated. About a third of the CSOs furthermore claimed that the EU funding has led to a more bureaucratic organization (see chapter 6).

In summary, only a small share of Swedish CSOs are financially Europeanized. Generally low dependency on public funding and good access to such funding at the national level seem to contribute to a low perceived relevance of EU funding. Furthermore, the fact that quite a large share of the CSOs see EU funding as involving high costs in terms of resources-both for applying for and administering such funding-is also a possible explanation for the low degree of financial Europeanization among Swedish CSOs. When it comes to mission drift and co-optation by means of EU funding, our results suggest certain adaptations but not anything involving changes in the core goals of the organization.

\section{Conclusions}

Using descriptive data from a large survey, this chapter has given a picture of the extent to which Swedish CSOs are Europeanized, the motives they state for addressing the European level, the ways in which they Europeanize, and the perceived outcomes of Europeanization. It suggests that Europeanization involves a minority of Swedish CSOs, which partly mirrors the fact that a large majority of the organizations involved in the survey are locally based. Political parties and interest organizations seem to be Europeanized to a larger extent than organizations representing diffuse interests, regardless of the type of Europeanization considered.

Regulatory Europeanization is mostly achieved through contacts withand intermediation of-domestic actors. While the political importance of the EU is in general perceived as low, Swedish CSOs seem to be quite successful in influencing policy at this level.

Organizational Europeanization seems to be a challenge for many organizations, at least when it comes to participation in activities. The complexity of the issues at the EU level is one of the major explanations. Participation can, however, give some positive outcomes such as remaining informed of what is happening in Brussels.

Financial Europeanization also presents certain challenges. It takes resources to apply for funding and to administrate the funds. The level of control and adaptation to EU requirements might be relevant but does not seem to apply for the organizations' central goals and mission.

All in all, Swedish CSOs seem to be well embedded in their national context when it comes to political influence, organizational affiliation, and 
funding. Our results suggest that the European level is more of a complement than an alternative to the domestic level for these organizations. To advance our understanding of these processes, the chapter 4 will deepen the analysis by addressing the factors behind and the interplay between different forms of Europeanization.

Roberto Scaramuzzino is Researcher at Lund University, Sweden. His research interests include changes in the welfare and integration systems and the role of CSOs in different countries. He has been engaged in comparative studies of mobilization in the migration and prostitution policy fields in Sweden and Italy, and at the EU level. He is currently working in a research program on civil society elites in Europe.

Magnus Wennerhag is Associate Professor of Sociology at the School of Social Sciences, Södertörn University, Sweden. He has a PhD in sociology from Lund University. His research mainly concerns social movements, political participation, social stratification and theories of modernity. His latest book is Radical Left Movements in Europe (Routledge 2018) coedited with Christian Fröhlich and Grzegorz Piotrowski.

\section{Notes}

1. For a methodological discussion about the survey and the dataset, see Appendix A; for the precise wording of all survey questions, their subitems, and the response alternatives, see Appendix C).

2. For a description of the principles guiding this categorization, see appendix A; for an overview of the specific types of organizations included in each type, see appendix B.

3. The organizational type "Other interest organizations for social groups" includes seventy-nine pensioners, thirty-nine immigrant, ten parents, six LGBT, and six student organizations, in addition to eleven organizations representing other specific group interests. A list of the organizations included in each type of CSO is presented in appendix B.

\section{References}

Ahrne, Göran, and Nils Brunsson. 2005. "Organizations and meta-organizations." Scandinavian Journal of Management 21, no. 4: 429-49.

Arvidsson, Malin, and Håkan Johansson. 2015. "The Practice of Giving Voice in Swedish Disability Organizations: From Political Social Movements to Lobbying 
Professionals?" Paper presented at the 5th European Conference for Social Work Research (ECSWR). Ljubljana, Slovenia, April 22-24.

Aytar, Osman. 2007. Mångfaldens organisering-Om integration, organisationer och interetniska relationer $i$ Sverige. PhD diss. Stockholm, Sweden: Acta Universitatis Stockholmiensis.

Beyers, Jan. 2002. "Gaining and Seeking Access: The European Adaptation of Domestic Interest Associations." European Journal of Political Research 41, no. 5: 585-61 2.

- 2004. "Voice and Access-Political Practices of European Interest Associations." European Union Politics 5, no. 2: 211-40.

- 2008. "Policy Issues, Organisational Format and the Political Strategies of Interest Organisations.” West European Politics 31, no. 6: 1188-211.

Beyers, Jan, and Bart Kerremans. 2007. "Critical Resource Dependencies and the Europeanization of Domestic Interest Groups." Journal of European Public Policy 14, no. 3: 460-81.

- 2012. "Domestic Embeddedness and the Dynamics of Multilevel Venue Shopping in Four EU Member States." Governance 25, no. 2: 263-90.

Bouwen, Pieter. 2002. "Corporate Lobbying in the European Union: The Logic of Access." Journal of European Public Policy 9, no. 3: 365-90.

Bäckström, Anders. 2014. "Välfärdsinsatser på religiös grund-Förväntningar och problem." In Välfärdsinsatser på religiös grund-Förväntningar och problem, edited by Anders Bäckström, 1 1-27. Skellefteå, Sweden: Artos and Norma.

Chalmers, Adam William. 2013. "Trading information for access: Informational lobbying strategies and interest group access to the European Union." Journal of European Public Policy 20, no 1.: 39-58.

Dahl, Svend. 201 1. "Efter folkrörelsepartiet: Om aktivism och politiska kursomläggningar i tre svenska riksdagspartier." PhD diss., Stockholm, Sweden: Stockholm University.

Danielson, Anna, Pär Zetterberg, and Erik Amnå. 2009. Bidrag till vad?-En kunskapsöversikt övereffekter och metoder rörande statliga bidrag till ideella organisationer. Stockholm, Sweden: Ungdomsstyrelsen.

della Porta, Donatella. 2013. "Europeanization and Social Movements." In The WileyBlackwell Encyclopedia of Social and Political Movements, edited by David A. Snow, Donatella della Porta, Bert Klandermans, and Doug McAdam. Chichester, UK: Wiley-Blackwell.

della Porta, Donatella, and Mario Diani. 2006. Social Movements: An Introduction, 2nd ed. Malden, MA: Blackwell.

Dür, Andreas, and Gemma Mateo González. 2012. "Who Lobbies the European Union? National Interest Groups in a Multilevel Polity." Journal of European Public Policy 19, no. 7: 969-87.

Feltenius, David. 2008. "From Outsiders to Influential Insiders: Pensioners' Organizations in the Policy Process in Sweden." Journal of Comparative Policy Analysis: Research and Practice 10, no. 1: 29-46.

Johansson, Håkan, Roberto Scaramuzzino, and Magnus Wennerhag. 2018. "Multilevel Strategies for Political Influence: How and Why do Domestic Civil Society Organisations seek Political Influence at National and EU Levels?" Journal of Contemporary European Research 14, no. 2: 68-86.

Klüver, Heike. 2010. "Europeanization of Lobbying Activities: When National Interest Groups Spill Over to the European Level." Journal of European Integration 32, no. 2: $175-91$. 
Linde, Stig. 2010. "Församlingen i granskningssamhället." PhD diss., Lund, Sweden: Lund University.

Linde, Stig, and Roberto Scaramuzzino. 2018. "Is the Church of Sweden an 'Ordinary' Civil Society Organization? The Advocacy Activities of the Church in Comparison to Other Civil Society Organizations in Sweden." Nordic Journal of Religion and Society 31, no. 2:. 118-138.

Lundström, Tommy, andLarsSvedberg. 2003. "TheVoluntarySectorinaSocialDemocratic WelfareState-TheCaseofSweden." JournalofSocialPolicy32, no. 2:217-38.

Lundström, Tommy, and Filip Wijkström. 1997. The Non-profit Sector in Sweden. Manchester, UK: Manchester University Press.

Markström, Urban. 2003. Den svenska psykiatrireformen: bland brukare, eldsjälar och byråkrater. PhD diss. Umeå, Sweden: Umeå Universitet.

Meeuwisse, Anna, and Sune Sunesson. 1998. "Frivilliga organisationer, socialt arbete och expertis." Socialvetenskaplig tidskrift 5, no. 2-3: 172-93.

Naurin, Daniel. 2001. Den demokratiske lobbyisten. Umeå, Sweden: Boréa Förlag.

Olsson, Lars-Erik, Marie Nordfeldt, Ola Larsson, and Jeremy Kendall. 2009. "Sweden: when strong third sector historical roots meet EU policy processes.” In Handbook on Third Sector Policy in Europe-Multi-level Processes and Organized Civil Society, edited by Jeremy Kendall, 159-83. Cheltenham, UK: Edward Elgar.

Salamon, Lester M., S. Wojciech Sokolowski, and Regina List. 2004. "Global Civil Society: An Overview." In Global Civil Society-Dimensions of the Nonprofit Sector, edited by Lester M. Salamon, 3-60. Bloomfield, CT: Kumarian.

Scaramuzzino, Gabriella, and Roberto Scaramuzzino. 2015. "The Weapon of a new Generation?-Swedish Civil Society Organizations' Use of Social Media to Influence Politics." Journal of Information Technology and Politics 14, no. 1: 46-61.

Scaramuzzino, Roberto. 2012. "Equal Opportunities? A Cross-national Comparison of Immigrant Organisations in Sweden and Italy.” PhD diss., Malmö, Sweden: Malmö University.

Scaramuzzino, Roberto, Cecilia Heule, Håkan Johansson, and Anna Meeuwisse. 2010. EU och den ideella sektorn-En studie av det svenska Equalprogrammet. FoU Rapport 2010-2. Malmö, Sweden: Malmö University.

Scaramuzzino, Roberto, and Magnus Wennerhag. 2013. "Influencing Politics, Politicians and Bureaucrats: Explaining Differences between Swedish CSOs' Strategies to Promote Political and Social Change." Paper presented at the ECPR General Conference. Bordeaux, France.

- 2015. "Civil Society Organizations Going European?: The Europeanization of Swedish CSOs." SAGE Open 5, no. 2: 1-14.

Svallfors, Stefan. 2015. "Politics as Organized Combat: New Players and New Rules of the Game in Sweden.” MPIfG Discussion Paper 15/2. Cologne, Germany: Max Planck Institute for the Study of Societies.

MUCF. 2016. Villkor för organisationer med social inriktning: Civila samhällets villkor 2015 med fokus på flyktingmottagande. Stockholm, Sweden: The Swedish Agency for Youth and Civil Society.

Ungdomsstyrelsen. 2013. Dialog, självständighet och långsiktiga förutsättningar-En uppföljning med ideella föreningar i fokus. Stockholm, Sweden: Ungdomsstyrelsen.

Wijkström, Filip, and Torbjörn Einarsson. 2006. Från nationalstat till näringsliv? Det civila samhällets organisationsliv i förändring. Stockholm, Sweden: European Civil Society Press. 
Chapter 4

\title{
FACTORS EXPLAINING SWEDISH Civil Society Organizations' EUROPEANIZATION
}

\author{
Roberto Scaramuzzino and Magnus Wennerhag
}

This chapter explores which factors contribute to whether Swedish civil society organizations (CSOs) become involved in regulatory, organizational, and financial Europeanization. We will focus on factors that previous literature has deemed important for CSOs' Europeanization-their availability of resources (number of members and paid staff) and their position in the organizational hierarchy (national, regional, or local)-but we will also analyze the relative impact of CSO type (i.e., the types of interests that the organizations represents) and whether CSOs perceive the EU to be a relevant political arena for solving the problems or issues they work with. We will also scrutinize whether CSOs' involvement in one type of Europeanization is correlated with their involvement in other types of Europeanization. Overall, the results show that resources, position in organizational hierarchy, CSO type, and perceived relevance all affect the likelihood of CSOs becoming Europeanized, but that these factors impact differently depending on the type of Europeanization considered. The analysis is based on data from a national survey among Swedish CSOs conducted in 2012-13 as part of the EUROCIV program.

In chapter 3 we used the same survey data to explore the ways in which contemporary Swedish CSOs are regulatory, organizationally, and financially Europeanized. The analysis revealed that some CSO types were in general more Europeanized, whereas others were less so, but also that some 
types of Europeanization were more common among specific CSO types. In this chapter we will go one step farther in the analysis. First, we will scrutinize whether the CSOs' involvement in one type of Europeanization leads to a similar degree of involvement in another type of Europeanization (i.e., if one finds correlations between different types of Europeanization). Second, we will make more complex statistical analyses in order to explain which factors contribute to whether Swedish CSOs become Europeanized. In order to see if different types of Europeanization are furthered by similar or different factors, we will perform the same type of analysis for regulatory, organizational, and financial Europeanization separately, but in these analyses we will also investigate how the different types of Europeanization affect each other.

In a previous study built on the EUROCIV survey (Scaramuzzino and Wennerhag 2015) we analyzed the degree to which Swedish CSOs that are active in the social welfare policy area carried out their activities at the European level and which factors most strongly contributed to such activities. The analysis showed that the strongest factor contributing to Swedish CSOs' degree of activity at the European level was the perceived relevance of this level for solving the problems or issues that they worked with. The availability of resources furthermore proved to be crucial, and CSOs that represented many members and had access to employed staff were more likely to be Europeanized. The analysis in that study was based on the CSOs' assessment of how often they had engaged in activities on the European level, which is a very general measure of the organizations' degree of Europeanization. In this chapter we will instead be more precise and look at the three types of Europeanization we discussed at length in chapter 3 in order to see whether the same factors are relevant for regulatory, organizational, and financial Europeanization. We are here foremost interested in CSOs' overall involvement in different types of Europeanization, and not the frequency or extensiveness of their involvement. We will analyze dichotomized variables that show whether the CSOs are at all involved in what can be regarded as different types of Europeanization.

We interpret and operationalize these three types of Europeanization in the following way.

- Regulatory Europeanization is when Swedish CSOs engage with public institutions at the EU level for the purpose of influencing policy; this is something that research on Europeanization of domestic interest groups has focused on (see Kanol 2016 for an overview). In the analysis we use the following question from the survey: "How often do you try to influence politicians or officials at the European level regarding issues that are central for your organization?" (to which the response 
alternatives were "often," "sometimes," "rarely," or "never"; the three former alternatives have been merged into a single value, to be contrasted to "never").

- Organizational Europeanization is when Swedish CSOs are members of umbrella organizations or networks at the European level. The increase of EU-based CSOs has been highlighted in research (Johansson and Lee 2014) as has been the participation of domestic CSOs in such networks as a form of Europeanization (Karlberg and Jacobsson 2015). In the analysis we use the following question from the survey: "Was the CSO a direct member of networks or federations at the EU or European level?" (to which the response alternatives were "yes" or "no").

- Financial Europeanization is when Swedish CSOs mobilize financial resources from EU institutions. The importance of EU funding for domestic CSOs has been highlighted by previous research (e.g., Sánchez-Salgado 2010; Scaramuzzino et al. 2010). To measure the level of Europeanization from this perspective, we use the following question from our survey: "How important is economic support from EU bodies for the budget of your organization?" (to which the response alternatives were "very," "somewhat," "not very," or "this is not a source of funding for us"; response alternatives one to three have been merged into a single value, and is in the analysis contrasted to the fourth response alternative).

When it comes to regulatory and financial Europeanization, our analysis is focused on the CSOs that sometimes have tried to influence politicians or officials at the European level (irrespective of how often) or have received some kind of economic support from EU bodies (irrespective of how important this is for the CSO's budget). This makes it possible to analyze these types of Europeanization in binary terms in the same way that we can analyze organizational Europeanization as a binary variable.

Chapter 3 contained bivariate analyses for all these three variables, and showed how the degree of Europeanization varied between different types of CSOs. In this chapter we will use a binary logistic regression to analyze whether other factors than CSO type affect the organizations' involvement in different types of Europeanization. As mentioned above, we will in particular analyze whether the CSOs' availability of resources, their organizational level, and the perceived political importance of the EU affect their likelihood of being Europeanized. These variables were introduced in chapter 3, for instance in connection to the bivariate analyses in table 3.1 (the availability of resources and organizational level) and table 3.4 (the perceived political importance of the European level). Our use of binary logistic regression 
models to analyze whether these different factors make CSOs more or less likely to be Europeanized will allow us to see these factors' relative impact when they are all taken into account in the analysis. In particular, this will show whether the variation we saw between different CSO types' degrees of Europeanization in chapter 3 (in tables 3.5 and 3.8, regarding regulatory and organizational Europeanization) can be seen as reflecting other types of differences between the CSO types. By controlling for factors such as the CSOs' availability of resources or their organizational level, we will be able to see how much the CSO types-which are more or less related to specific policy areas and interests-explain in the end. All in all, this analysis will help us to give a more nuanced explanation of why only a minority of Swedish CSOs are Europeanized.

Previous research on the Europeanization of interest groups and social movements has shown that both organizational and institutional factors are important for whether and how CSOs come into contact with EU institutions and organizational networks at the European level. These theories will be considered later in this chapter when we discuss possible explanations for the different patterns of Europeanization that can be found among Swedish CSOs. In our analysis, we will explore the role of organizational factors in terms of the type of interests represented (e.g., Beyers 2004; Chalmers 2013; Dür and Mateo 2012), the CSOs' availability of resources such as membership and staff (e.g., Klüver 2010), and their dependency on resources such as public funds (e.g., Beyers and Kerremans 2007). Among institutional factors (e.g., Beyers 2008; Beyers and Kerremans 2007) we will take into account the CSOs' position in the organizational hierarchy (whether they are local, regional, or national organizations) and the main policy area they are involved in. In line with our previous findings (Scaramuzzino and Wennerhag 2015), we will also focus on how the organizations perceive the political context in which they work, especially how relevant they deem the European level and the EU institutions for their own activities and goals.

\section{Do Different Types of Europeanization Correlate?}

Before presenting the results of the regression analyses, we want to discuss how one can understand the relationship between the three types of Europeanization. How closely related are these different types of Europeanization? Is it, for instance, more likely that organizationally Europeanized CSOs are simultaneously more financially Europeanized? Or, on the contrary, does involvement in one type of Europeanization lead to less involvement in another type? 
In chapter 1 Jacobsson and Johansson argued that different types of Europeanization need to be analytically separated because they concern different types of influence that are characterized by specific mechanisms that place CSOs in different subject positions or roles. In chapter 3 our analysis showed that some types of CSOs tend to be more Europeanized than others in many ways, but it also showed that some types of CSOs were more Europeanized in some ways and less in others. However, we did not explicitly analyze to what degree various types of Europeanization correlate with each other.

Table 4.1 shows the degree to which the three types of Europeanization are statistically correlated. There are positive correlations between all three variables, which means that involvement in one type of Europeanization makes it more likely for a CSO to also be involved in other types of Europeanization. The strongest correlation is between regulatory and organizational Europeanization. This suggests that being active in networks at the EU level is partly based on motives of gaining access to and influencing policymaking processes at the European level. However, even though the correlations are positive, they are not extremely strong, and they account for only around 20-30 percent of the covariation between the variables. This shows that, in general, the three different types of Europeanization analyzed here do not follow exactly the same pattern. Whether these differences can be explained by other factors will now be examined in the remaining part of this chapter.

\section{Explaining Europeanization}

We will now analyze the impact of various factors on whether Swedish CSOs are Europeanized according to the three types of Europeanization discussed above. The statistical method used is binary logistic regression. This type of regression plots so-called odds ratios for each factor (in table 4.2 these are labeled $\operatorname{Exp}(\mathrm{B})$ ); in other words, a figure for how the probability of having a specific quality (here, being Europeanized) is affected by other characteristics (e.g., resources) when the effects of many variables are analyzed simultaneously. This will allow us to see the relative impact of various factors on CSOs' Europeanization.

The three (binary) dependent variables are the ones we presented earlier in this chapter: regulatory, organizational, and financial Europeanization. These will be analyzed in three separate regression models. The independent variables include CSO type (the same types that were discussed in chapter 3; see also appendixes A and B), and the control variables include the CSOs' position in the organizational hierarchy (whether they are local, 


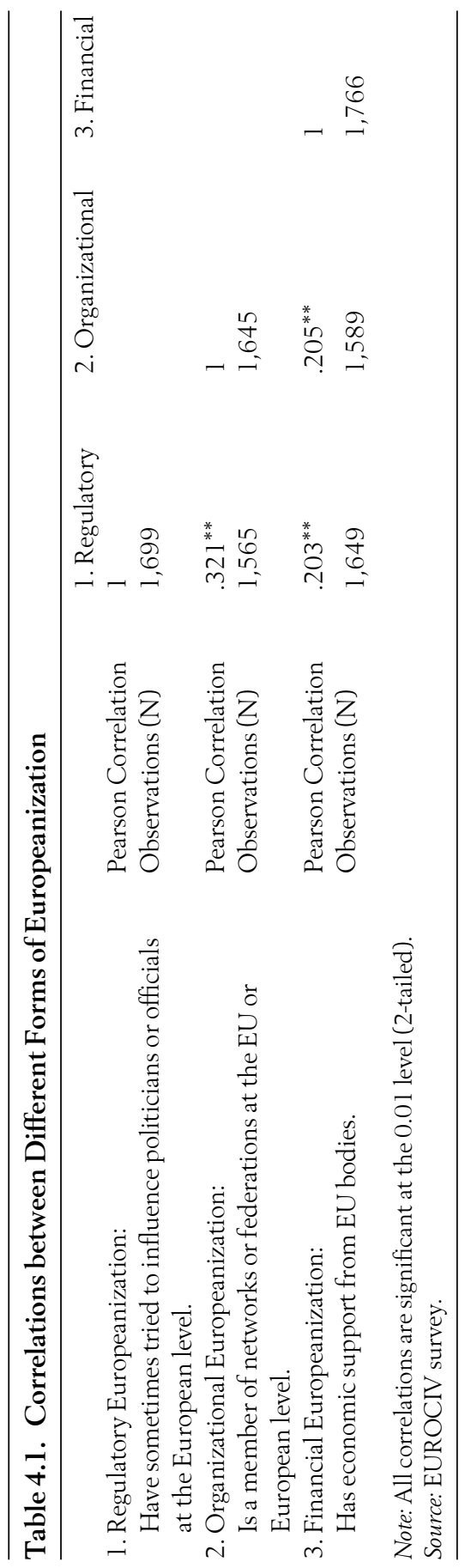

This open access library edition is supported by the University of Lund. Not for resale. 


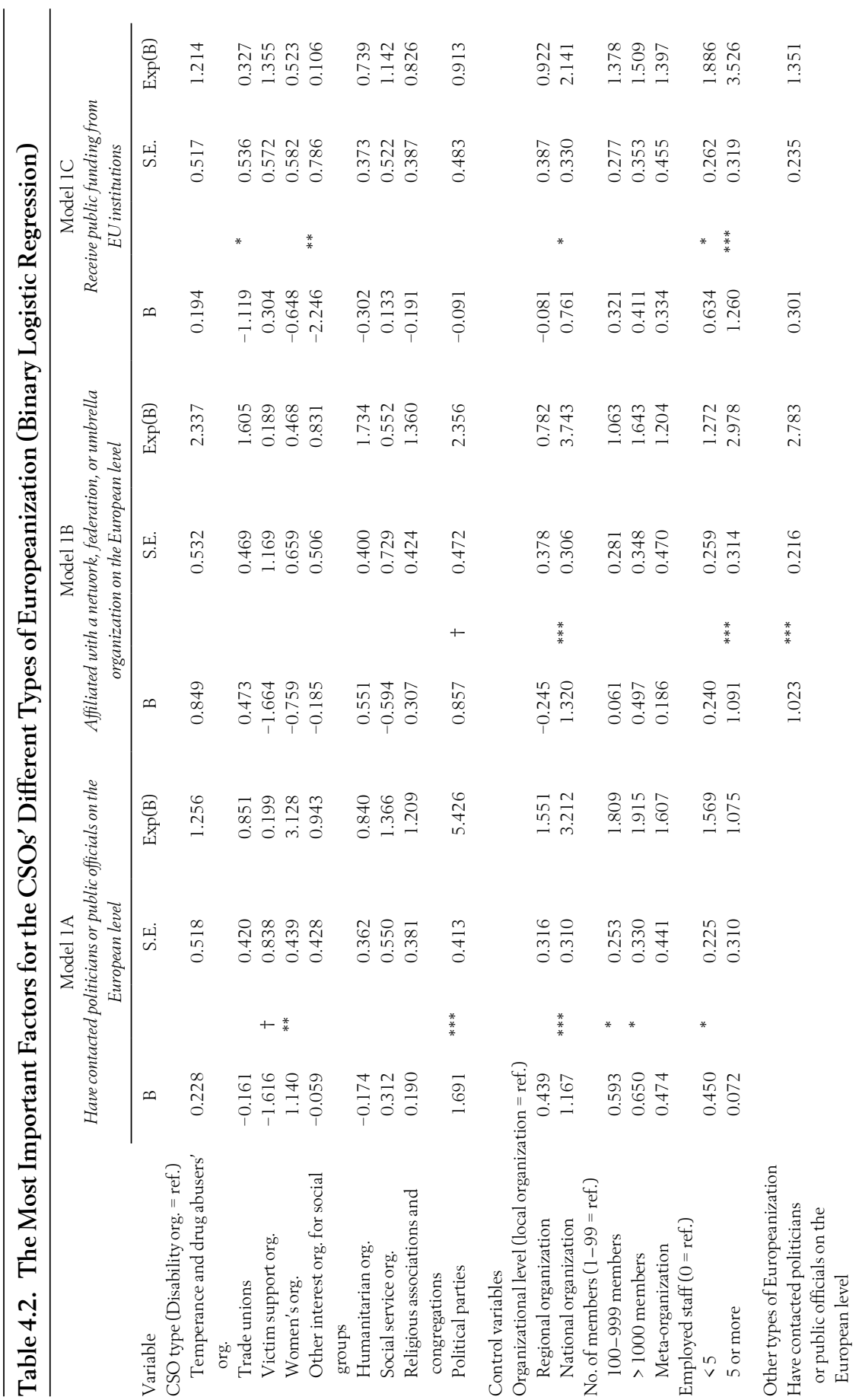


in

$\frac{\text { i }}{\stackrel{ \pm}{ \pm}}$

$\stackrel{0}{\text { I }}$

$\stackrel{m}{2}$

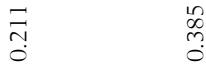

$+$

$\stackrel{i n}{\dddot{m}}$

3
$\stackrel{0}{0}$

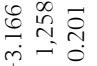

$\dot{p}-\dot{0}$

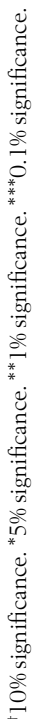

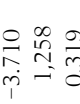

$\stackrel{Ð}{\stackrel{0}{0}}$

$\stackrel{N}{N}$

$\stackrel{\vec{v}}{0}$

$\stackrel{\infty}{\stackrel{7}{\sigma}}$

**.

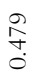

$\circ$
$\stackrel{2}{\circ}$
0

$\stackrel{\circ}{\circ}$

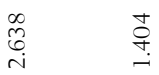

مै

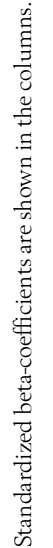

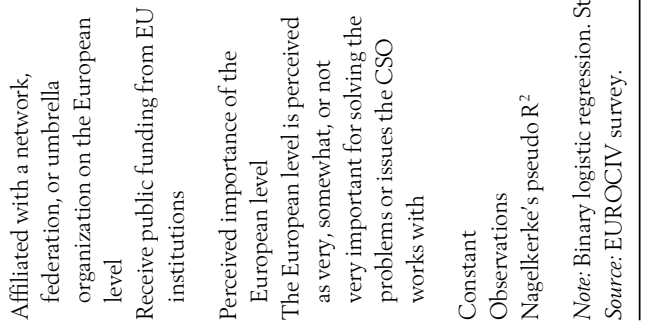

This open access library edition is supported by the University of Lund. Not for resale. 
regional, or national organizations), the type of organization (whether they have individual members or are umbrella organizations), and their available resources (in terms of members and paid staff). For each model we have also included the other two types of Europeanization as independent variables to see whether they also impact the specific type of Europeanization being analyzed. The final independent variable is the CSOs' perceived relevance of the European level-in other words, whether they perceive this level as being at all important for solving the problems or issues that their organization works with.

As discussed earlier in this chapter, we have previously shown that the perceived importance of the European level was the strongest factor for explaining why Swedish CSOs were active at the European level (Scaramuzzino and Wennerhag 2015). The same analysis also showed that CSOs with greater numbers of members were slightly more active on the European level. In this sense, we argued that one could find both a cognitive threshold (the perceived relevance of the European level) and an organizational threshold (the availability of resources, in terms of members) affecting Swedish CSOs' degree of Europeanization.

The perceived relevance of the European level should here be understood as whether CSOs perceive opportunities at the European level as being relevant. This makes it possible to assess not only the CSOs' actual opportunities (for influencing EU policies, receiving EU funding, or seeking organizational cooperation on the European level), but also if they deem it relevant to consider taking these opportunities. Opportunities are not only structural and embedded in institutions-they are also framed and understood within a specific cultural and political context and can thus be understood differently by different actors (Gamson and Meyer 1996). In the following regression models we will test the hypothesis that the perceived relevance of the European level explains whether Swedish CSOs are Europeanized concerning all three types of Europeanization discussed in this chapter.

Table 4.2 presents three regression models, one for each type of Europeanization. The effect of CSO type for organizations' likelihood to be Europeanized differs in the three models. Disability organizations have been chosen as the reference in all regression models because this type of $\mathrm{CSO}$ seemed to display an average pattern of Europeanization in the bivariate analysis presented in chapter 3 . The significant differences thereby show whether other CSO types are more or less Europeanized than disability organizations.

When it comes to regulatory Europeanization, political parties and women's organizations are more likely to be Europeanized. The fact that political parties are more likely to make contacts with politicians or public officials on the European level illustrates their central role in the political 
system, and supposedly much of these contacts are made within the parties themselves and through the EU-level party structures that they are often a part of. In chapter 3 we showed that the most frequent form of advocacy Swedish CSOs use to influence EU policies is to contact domestic political parties or domestic authorities. The fact that Swedish political parties are much more Europeanized than other Swedish CSOs suggests that they play an important role as an intermediary link between domestic CSOs and EU institutions. Political parties are also slightly more likely than other CSOs to be members of European networks or organizations. However, when it comes to financial Europeanization-in other words, whether one receives economic funding from EU institutions-the political parties do not differ from other CSOs. The trade unions do differ from the other organizations in this respect, and thus seem to be less likely than other CSOs to be financially Europeanized. It is important, however, to acknowledge that trade unions in general are much less dependent on public funding compared to other types of CSOs, even when it comes to funding from the state and local municipalities (see table 3.9 in chapter 3).

National organizations are more likely to be Europeanized than are local and regional organizations regarding all three types of Europeanization. This difference is most marked when it comes to organizational Europeanization. National organizations are 3.7 times more likely to be affiliated with a network, federation, or umbrella organization on the European level. This is most probably an effect of the predominant way in which organizational networks on the European level function, which is primarily to link national organizations to each other. Considering the fact that a large majority of CSOs (74 percent) are members of national umbrella organizations or federations, it seems reasonable to assume that such national organizations function as representatives for local CSOs in the European organizations and networks.

A large membership base is an important factor for explaining CSOs' likelihood of being regulatory Europeanized. Our analysis shows that CSOs that can claim strong representativeness by having many individual members are more likely to get access to the European political level in terms of having contacted politicians or public officials. Also, the availability of employed staff is shown here to be important for explaining why CSOs become Europeanized. This is particularly the case when it comes to their affiliation to networks and organizations at the European level and their access to funding from EU institutions. In chapter 3 we showed that a large share of the CSOs participating in European networks experienced this as both time and resource consuming and that they perceived the complexity of EU-level issues as a further obstacle in this work (see table 3.3 in chapter 3). In the previous chapter, we also discussed how almost all CSOs that 
had applied for EU funding experienced this as creating large administrative burdens. For CSOs having employed staff, such obstacles would most probably be smaller, which helps us to better understand why the availability of employed staff is an important factor for whether CSOs become Europeanized.

The importance of resources has also been highlighted in previous research on interest groups' Europeanization. Klüver (2010) mentions three types of resources that are relevant for meeting the demands of the EU: financial resources, personnel resources, and interest group representativeness. Because EU institutions are often understaffed, they need the interest organizations they interact with to compensate for their own lack of expertise. The democratic deficit of EU institutions might furthermore be compensated by the CSOs with which they interact if the CSOs can claim strong representativeness and thereby strengthen the legitimacy of the EU-level political processes in which they take part. Our study confirms that resources such as membership and employed staff play a decisive role in whether CSOs become Europeanized, but at the same time we show that these types of resources are more or less crucial depending on which type of Europeanization is being considered.

In line with the correlations that were shown in table 4.1, the three different types of Europeanization are also shown to strengthen each other in most of the regression models in table 4.2. It is especially regulatory Europeanization and organizational Europeanization that strengthen each other.

Finally, our hypothesis that the extent to which the CSOs see the European level as relevant for them is crucial for their involvement in Europeanization finds strong support from the results of all regression models. This is particularly the case for regulatory Europeanization. CSOs that perceive the European level as important for solving the problems or issues they work with are almost eleven times more likely to contact politicians or public officials on the European level compared to CSOs that do not see the EU level as important. This is the single most important factor for explaining CSOs' likelihood of being regulatory Europeanized. This factor should be seen as measuring whether the CSOs perceive the $\mathrm{EU}$ institutions as providing them with new political opportunities that they potentially can make use of (cf. Gamson and Meyer 1996). Behind this perceived opportunity one might of course find a lot of other factors, such as whether the EU actually has a say in the policy areas that the CSOs are engaged in, whether the CSOs have knowledge about the competencies of the EU in such policy areas, or whether the CSOs believe that the EU is capable of solving their most central issues. Even though this factor has the strongest impact on the CSOs' regulatory Europeanization, it also to some degree explains their organizational 
Europeanization (odds ratio 2.7) and financial Europeanization (odds ratio 2.1). This shows that for being connected to the European level-whether for seeking political influence, having an organizational affiliation, or receiving economic resources-it is more or less crucial that Swedish CSOs perceive the European level as relevant for them.

\section{Conclusion}

In this chapter we analyzed the relative impact of various factors that might contribute to CSOs' likelihood to become Europeanized. In line with previous literature, our analysis showed that CSOs' availability of resources (in particular paid staff) and their position in the organizational hierarchy (in particular those operating on the national level) were important factors for CSOs to become involved in different types of Europeanization. Our analysis also showed that some types of CSOs, working within specific policy areas, were more likely to become Europeanized. The single most important factor was, however, whether the CSOs perceived the EU to be a relevant political arena for solving the problems or issues they work with, which indicates that the CSOs' perception of the new political opportunites that the EU institutions provide them with are crucial for their actual use of such opportunities. Moreover, our analysis showed that the impact of these factors varied between different types of Europeanizationregulatory, organizational, and financial-and that involvement in one type of Europeanization tends to strengthen CSOs' involvement in other types of Europeanization.

Roberto Scaramuzzino is Researcher at Lund University, Sweden. His research interests include changes in the welfare and integration systems and the role of CSOs in different countries. He has been engaged in comparative studies of mobilization in the migration and prostitution policy fields in Sweden and Italy, and at the EU level. He is currently working in a research program on civil society elites in Europe.

Magnus Wennerhag is Associate Professor of Sociology at the School of Social Sciences, Södertörn University, Sweden. He has a PhD in sociology from Lund University. His research mainly concerns social movements, political participation, social stratification, and theories of modernity. His latest book is Radical Left Movements in Europe, coedited with Christian Fröhlich and Grzegorz Piotrowski (Routledge, 2018). 


\section{References}

Beyers, Jan. 2004. "Voice and Access-Political Practices of European Interest Associations." European Union Politics 5, no. 2: $211-40$.

- 2008. "Policy Issues, Organisational Format and the Political Strategies of Interest Organisations." West European Politics 31, no. 6: 1188-211.

Beyers, Jan, and Bart Kerremans. 2007. "Critical Resource Dependencies and the Europeanization of Domestic Interest Groups." Journal of European Public Policy 14, no. 3: 460-81.

Chalmers, Adam William. 2013. "Trading Information for Access: Informational Lobbying Strategies and Interest Group Access to the European Union." Journal of European Public Policy 20, no. 1: 39-58.

Dür, Adam, and Gemma Mateo González. 2012. "Who Lobbies the European Union? National Interest Groups in a Multilevel Polity." Journal of European Public Policy 19, no. 7: 969-87.

Gamson, William A., and David S. Meyer. 1996. "Framing Political Opportunity." In Comparative Perspectives on Social Movements: Political Opportunities, Mobilizing Structures and Cultural Framings, edited by Doug McAdam, John D. McCarthy, and Mayer N. Zald, 275-90. Cambridge, UK: Cambridge University Press.

Johansson, Håkan, and Jayeon Lee. 2014. "Bridging the Gap: How Do EU-Based Civil Society Organisations Acquire Their Internal Representation?" VOLUNTAS: International Journal of Voluntary and Nonprofit Organizations 25, no. 2: 405-24.

Kanol, Direnç. 2016. "Europeanization of Domestic Interest Groups." Interest Groups \& Advocacy 5, no. 2: 165-71.

Karlberg, Eva, and Kerstin Jacobsson. 2015. "A Meta-organizational Perspective on the Europeanization of Civil Society: The Case of the Swedish Women's Lobby." VOLUNTAS: International Journal of Voluntary and Nonprofit Organizations 26, no. 4: $1438-59$.

Klüver, Heike. 2010. "Europeanization of Lobbying Activities: When National Interest Groups Spill Over to the European Level.” Journal of European Integration 32, no. 2: $175-91$.

Sánchez-Salgado, Rosa. 2010. "NGO Structural Adaptation to Funding Requirements and Prospects for Democracy: The Case of the European Union." Global Society, 24, no. 4: 507-27.

Scaramuzzino, Roberto, Cecilia Heule, Håkan Johansson, and Anna Meeuwisse. 2010. EU och den ideella sektorn-En studie av det svenska Equalprogrammet. FoU-rapport 2010: 2. Malmö, Sweden: Malmö University.

Scaramuzzino, Roberto, and Magnus Wennerhag. 2015. "Civil Society Organizations Going European?: The Europeanization of Swedish CSOs.” SAGE Open 5, no. 2: $1-14$. 
Chapter 5

\title{
ACCESS TO THE EUROPEAN UNION AND THE ROLE OF DOMESTIC EMBEDDEDNESS
}

\author{
Elsa Hedling and Anna Meeuwisse
}

The Europeanization of civil society comes in many shapes and forms, as illustrated by Jacobsson and Johansson in chapter 1 of this volume. Accordingly, there are numerous dimensions at play in Europeanization processes that could have implications for civil society organizations (CSOs) in Sweden. In this chapter we focus on capturing the participatory and organizational dimensions of the Europeanization of civil society. Specifically, we consider the conditions for access to the European Union (EU) level and whether successful reach is dependent on a privileged position at the member state level. Consequently, we also consider the transition of the Swedish civil society that has taken place since the 1990s, which is also likely to have influenced positions of domestic embeddedness.

The EU is often framed as an elite project, and it has struggled to overcome this nondemocratic label. One of the strategies for enhancing EU democracy has been to pay more attention to national civil society actors; CSOs from around the member states are encouraged to participate in EU politics through various consultation processes. But who are these organizations, and how have they reached the EU level? Is it possible that despite the ambitions of an open invitation, the EU is creating a VIP lane that is once again reproducing the circle of privilege?

Previous research has both confirmed and opposed the decisive role that domestic embeddedness plays in Europeanization. Some studies have found 
access to national political authorities to be crucial for successful EU engagement among CSOs based on the argument that institutionalized relations between state actors and interest associations carry over to the European level (Eising 2007; Pierson 2000). Other findings seem to indicate the opposite. In these studies it is rather those that are marginalized at the national level that are inclined to actively seek leverage with the EU (Fairbrass and Jordan 2001; Keck and Sikkink 1998; Marks and McAdam 1996). Is it thus possible that the EU is an arena that could both reproduce existing hierarchies among CSOs while at the same time allowing for the emergence of new actors and power structures in the field?

In a previous study (Hedling and Meeuwisse 2015) we found that Swedish CSOs in the welfare field that were engaged in a formal agreement with the state had high levels of Europeanization, contradicting previous findings of limited EU influence in the Swedish civil sphere (see Olsson et al. 2009). This study was, however, conducted on a relatively small sample of fifty-six organizations with formalized ties to the Swedish government; this particular group of organizations renders the role of domestic embeddedness relevant. The results stressed the need to return to the ever so relevant discussion of bottom-up versus top-down political processes of European integration (cf. chapter 1). In this chapter we test the hypothesis that national political access increases the likelihood of Europeanization, hence reproducing existing hierarchies, among a broad range of almost three thousand Swedish CSOs, a sample generated through the survey presented in the previous chapters. (For detailed information about the database, see appendix A.)

\section{Elite Access and Domestic Embeddedness}

The very idea of an elite within civil society might at a normative level be seen as a contradiction in terms. ${ }^{1}$ Civil society is often contrasted with political elites as representing the community of citizens outside the ruling class. In this sense, there is a reluctance to speak of elite CSOs because such a categorization goes against the normative ideals of the democratic public sphere. In reality, there has of course always existed stratifications among civil society, power struggles among organizations, and winners and losers in the quest to obtain political influence. Among other things, aspects of elite access and/or domestic embeddedness might characterize such stratification. Elite access refers to privileged access to sources of political power that can be reached through different forms of capital (Johansson and Kalm 2015). Domestic embeddedness supposes an institutionalized position of privilege and thus influence through established positions and channels. 
The idea of a civil society elite is therefore interesting to consider in relation to at least two aspects of democracy.

First, the actual composition of a civil society elite might be far from naturally given. Different forms of capital can be used to reach elite access, and the value of political, economic, social, and symbolic capital might vary across time and space. For instance, the hierarchical structure in the private sector in a given country might not automatically transfer to the civil society sector. Second, an elite group might not only carry political input (such as advocacy and political demands) but might also be the bearer of political output (e.g., legitimizing functions). This is particularly intriguing when considering civil society, which traditionally has been considered a cornerstone of democracy. The privileged position of a civil society elite group might, therefore, not only grant political influence, but might also produce socialization and loyalty to the system.

To arrive at our understanding of what constitutes a national civil society elite we build on two strands of literature: the insider/outsider thesis in public policy research and the idea of access points in interest group research.

Public policy research has repeatedly shown how interest groups' relationships to the state and their subsequent strategies matter in the explanation of the success of some groups and the failure of others in seeking political influence (e.g., Beyers 2002; Grant 1978, 2000; Maloney, Grant, and McLaughlin 1994). These relationships have been explained through a number of theoretical models, all of them concerned with the role of access to power. In public policy literature, this phenomenon is often illustrated through the insider/outsider divide, linking groups' policy influence to their position in the consultative process. The insider/outsider thesis departs from the distinction of an insider group with privileged access to the executive power and direct strategies of pressure in relation to an outsider group that is limited to indirect strategies. These strategies might be more or less constrained or free depending on the context of the groups' positions; while some groups are actively seeking insider status, others might be given privileged positions without even trying to obtain them. Following this reasoning, there have been numerous attempts to expand the insider/outsider divide through subcategorizations in both groups (Grant 1999).

Interest group research has been equally intrigued by the success or failure of groups to reach the inner spheres of political authority, but such research has usually focused on access rather than successful influence over policy. While access is considered necessary to have influence on policy, it is not equal to having influence; rather, the focus on access is seen as an attempt or even a strategy in its own right (Beyers 2002).

Interest group research has further applied these ideas of access-seeking strategies on the EU level. The EU is a complex system of multileveled 
governance that has received increasing attention from civil society. This is partly a result of the EU's own attempts of including civil society but is likely also a sign of institutional learning and the growing awareness of EU access points among CSOs around Europe. There are different understandings of how to transfer the knowledge of domestic access points to the EU level. As mentioned earlier, some suggest that access to domestic public authorities increases the chances of access to the EU level, while others claim such a relationship would rather hinder the emergence of EU-level access. When the EU level becomes institutionalized in member states' politics, the extension of access points might seem a natural development of the opportunity structure available to privileged interest groups (Eising 2007; Pierson 2000). These organizations might be better prepared for the European level because of their experiences in domestic politics, and they might also enjoy privileged resources (both economic and human capital) in their adaptation to the more complex EU-level politics. This view would thus argue for a tendency toward Europeanization through the reinforcing of domestic patterns of interest representation (Beyers 2002). The opposite view suggests that it is instead domestically marginal groups that would seek access because they are in greater need of the new opportunity structures provided by EU membership (Fairbrass and Jordan 2001; Keck and Sikkink 1998; Marks and McAdam 1996). In cases where specific civil society interests are not given attention at the domestic level, access at the European level could both increase the status at the domestic level and potentially lead to influence in the EU.

In order to allow for empirical exploration, Jan Beyers (2002) suggests four different correlates between domestic interest groups gaining and seeking access at the EU level: (1) The potential correlation of domestic privilege persisting at the EU level is labeled the positive persistence hypothesis. (2) The opposing idea, suggesting that actors stay where they are and would rather be constrained by domestic institutional persistence, is called the negative persistence hypothesis. (3) The belief that actors that are marginalized at the domestic level will seek to compensate through access at the EU level is labeled the compensation hypothesis. (4) No change at all is called the reversed positive persistence hypothesis.

Elite access and domestic embeddedness might have implications for the different patterns of Europeanization we might encounter in different member states. Both the insider/outsider thesis and the access point thesis suggest that interest groups are actively positioning themselves and profiting vis-à-vis national governments. These assumptions stress the need for a contextual understanding in an analysis that combines different types of Europeanization with the specific characteristics and implications of domestic embeddedness, in our case in Sweden. 


\section{Participatory and Organizational Europeanization}

Participatory Europeanization refers to the ways in which the EU provides new opportunities for civil society to participate in EU politics. The underlying idea is that participation in EU politics will bring effects of Europeanization, which can be understood as changes from a national tradition to EU political socialization. The forms of participation might differ, and we have previously mentioned EU-level consultation procedures and civil dialogues, but EU participation might also take place at national or even local levels in the multileveled EU system (Greenwood 2011). A very common form of participation is, for instance, the projects associated with the large structural funds in the EU, such as the EQUAL Community Initiative (Scaramuzzino et al. 2010). These opportunities are themselves effects of Europeanization, but they might also act as catalysts for increasing Europeanization through mechanisms of adaptation, social learning, professionalization, networking, and access granting (Sánchez-Salgado 2010). These Europeanization effects might transcend from mere participatory experiences into the greater society, potentially making CSOs agents of political socialization (Warleigh 2001). However, due to high demands for professionalization and resources, these opportunities might or might not be available to civil society actors and hence might constrain the participation of certain actors. Another way of participating in EU politics is through the new opportunities for using national political levels as representatives to the EU level. Although organizations might not be active on the EU level, they might still be actively participating in EU politics through the representative channels at the member state level. Civil society actors might thus become both objects and subjects of participatory Europeanization.

Organizational Europeanization is in the context of civil society closely related to participation because of the ambitions of including civil society in the EU, and the opportunities for participation at the EU level have brought about processes of meta-organization in European civil society. The assumption is thus that EU politics bring effects of Europeanization, which are understood as changes from traditional national forms of organization to congruency with EU organizational logics. Civil society interest representation is to a large extent organized by meta-organizations representing clusters of umbrella organizations with links to national levels. The process of inclusion has therefore brought both opportunities and demands for Europeanlevel organization. These processes of increasing transnational organizations have also influenced the national, regional, and local levels of civil society in EU member states (Karlberg and Jacobsson 2014). National organizations are invited to join umbrella organizations where engagement with the EU 
is collectively coordinated at times through representation in meta-level networks that have privileged access to EU institutions. Organizational Europeanization can also be found in an increasing local interest in the EU political agenda, applications for EU funding, and participation in projects that support not only participation but also organizational adaptation and socialization.

At first glance participatory and organizational Europeanization might come across foremost as structural results of the new EU channels of influence, engagement, and networking. Interest in or adaptation to these forms of institutional logics might, however, bring with them the cognitive and social influence of discursive or identity Europeanization (cf. chapter 1). Although we do not investigate these forms of Europeanization directly, they are implicitly related.

\section{A Swedish Civil Society in Transition}

The role of civil society in Sweden has undergone changes since the 1990s; those changes have implications both for the understanding of elites within civil society and for the conditions for participation at the EU level. The Scandinavian and Swedish model of civil society is often depicted as different from other models (Selle and Wollebaek 2010), and it is commonly held that Scandinavian countries rest on a long tradition of large popular movements such as the women's, temperance, and labor movements. An important feature of the Swedish model has traditionally also been neo-corporatism such as an unusually close collaboration between the state and major interest organizations in the preparation and implementation of public policies (Rothstein 2001). The popular movements eventually became closely interwoven with the state apparatus, described as their institutional embedding in Swedish society (Amnå 2008). The popular movements and the welfare state institutions grew up side by side in a kind of symbiosis and interdependence where they both inspired and came to define each other.

Some also maintain that Swedish civil society actors have primarily fulfilled an expressive function and represented members and beneficiaries vis-á-vis the state; to a lesser extent they also have been engaged in service production. Unlike many other countries, the absolute majority of all welfare services in Sweden have been provided by the public sector, and the affinity between the popular movements and the state has instead been founded on the ideological proximity between the social-democratic welfare regime and the political values and goals of many of the popular movements (Wijkström 2011). ${ }^{2}$ Last but not least, it has generally been held that Swedish civil society rests more on its members' unpaid work than on 
professional engagements. Historically, the members, who in their layman's capacity provide both the unpaid work and also contribute much of the funding for their organizations, dominate the popular movement organizations (Lundström and Wijkström 1997). However, many of these organizations continued to grow in size and importance in the second half of the twentieth century and were then often led and staffed by paid professionals and were also partly publicly funded (Einarsson and Hvenmark 2012). The funding was often tightly coupled with the number or share of members, and the membership cadres of the organizations hence became important as revenue generators for governmental and municipal financial support.

During the past few decades, a series of social, political, and technological changes have altered the conditions under which Swedish CSOs operate (Amnå 2006). Research regularly points at an increasing NGO-ization, bureaucratization, and professionalization among civil society actors that directly challenge Swedish CSOs as membership-based organizations (Papakostas 2004, 2011). Professional activists, campaign experts, sponsor consultants, project managers, directors, and movement entrepreneurs have to some degree replaced the elected leaders. CSOs, particularly in the welfare area, increasingly recruit staff selected on the basis of their professional skills and tend to adapt to market and public sector management models, such as when it comes to quality assurance and monitoring (Linde 2010). In addition to the expansion of paid staff, there has been an increase in the time provided by volunteers (Wijkström 2011). Meanwhile, the popular movement organizations are often claimed to be experiencing a crisis, with symptoms such as decreasing membership, active members turning passive, and reduced political influence (Amnå 2007). More-fluid forms of mobilizing and organizing complement such internal changes, and processes of individualization have made individuals less inclined to participate in formal associations and have instead fostered orientation toward short-term engagements.

At the same time, studies demonstrate a growing and more diverse array of organizations involved in Swedish civil society, and calculations estimate a total of approximately 210,000 formal CSOs in Sweden (Statistics Sweden 2010). New actors have entered the civil society field, such as service providers in the form of social cooperatives or social enterprises trying to combine business models with social missions (Wijkström 2012). The long-marginalized charity tradition of the nineteenth century has also been brought back to life and regained legitimacy. Such internal changes to civil society itself take place against the backdrop of changing expectations from the Swedish state and public agencies with regard to civil society. Research shows that the Swedish government over time has encouraged an increasing number and diversity of CSOs to take part in the policy process, but that access is slightly skewed in favor of organizations with an insider position at the national government 
level(Lundberg 2014). Public agencies increasingly seek to engage civil society actors as experts, advisers, or partners in policymaking processes (Johansson, Kassman, and Scaramuzzino 2011; Johansson and Johansson 2012). The traditional popular movements have met competition from other civil society actors regarding relations and access to the government, and the dialogue between civil society and the state is now played out in partly different forms and in new arenas. Many of these activities take place in committees and through consultation processes and partnership arrangements. Such institutionalized participatory arrangements potentially challenge established orders in the field because participation can give privileged access to resources by some, while others are excluded. It also leads to questions regarding civil society representatives' independence from the state.

Furthermore, the EU has become a new political level that the organizations somehow have to relate to. As mentioned in the introduction to this volume, the EU offers new opportunities but has also been thought to represent values that are contrary to the open, democratic, and social citizenship-oriented Swedish welfare model (Olsson et al. 2009, 178). It is against this background of altered conditions for CSOs that we investigate the hypothesis that domestic political access increases the likelihood of Europeanization.

\section{Characteristics and Implications of Embeddedness in the Swedish Case}

Our previous study (Hedling and Meeuwisse 2015) largely supports the positive persistence hypothesis indicating that in Sweden a group of CSOs that enjoyed close relationships to the Swedish government signaled high levels of Europeanization. In order to further explore this intriguing possibility of a domestically embedded correlation, we revisit the positive persistence hypothesis, but this time in a large $\mathrm{N}$ investigation. If the hypothesis finds support it would mean that EU engagement is reproducing certain patterns of influence in Swedish civil society. After having identified an elite group through three criteria outlined below, we engaged with both quantitative and qualitative material produced through the survey. We further complemented the material with information from the organizations' websites.

\section{The Three P's of Embeddedness Criteria}

The discussions on insider/outsider positions and access points indicate that the relationships between national governments and interest groups seem 
to be an important part of understanding civil society strategies as well as determining the success of these organizations in influencing policy. How these ideas translate to the European level is less clear, and there are valid arguments both in favor of and opposed to the positive persistence theory. In order to investigate this, we first turn to the recognition of these supposed elite groups of embeddedness. What are the characteristics by which these insiders or groups with privileged access can be identified? Two common ways of identifying these groups are through their status in relation to the state and through their strategies vis-à-vis the state (Beyers 2002; Grant 1978; Maloney, Jordan, and McLaughlin 1994). In our selection of criteria, we lean on the former understanding of embeddedness as foremost a question of status that in turn has implications for the strategies used by these groups.

\section{Privilege}

Insiders, or those with access, are privileged in relation to outsiders, or those without access. This privilege might be a question of institutionalized consultative relationships (e.g., access to governmental commissions and the Swedish government consultation), favored political topics (agenda setting, what issues are considered important and valid), or economic support. These are all benefits of a valued relationship that grants these groups the access and political legitimacy of a favorable status position (Grant 1978).

\section{Proximity}

Privilege also assumes actors to be situated close to the center of authority, to have proximity. Proximity can be understood in terms of ideology, geography, or frequency of contact. Ideological proximity might constitute a relationship between a specific government and organizations with shared political values. Geographical proximity might seem irrelevant, but organizations with geographical access might have more opportunities for fostering relationships through both formal and informal personal contacts. For instance, centralized political systems might favor consultations with organizations based in national capitals. On the other hand, while national organizations are often based in capitals, the distinction between local and national is less evident in capital-based groups of organizations. A sense of proximity can also be developed through frequency of contact. When organizations are engaged in consultative processes on a regular basis, the 
relationship to the state might grow closer as a result of habitual and institutionalized behavior.

\section{Professionalization}

Finally, in order to maintain a privileged position in proximity to domestic governments it is reasonable to assume that these actors maintain a certain level of professionalism. While Swedish civil society still to a large extent functions without employed staff (cf. chapter 3), an international trend of professionalization has been documented (Wijkström and Einarsson 2006; Åberg 2013). It has become more common for CSOs to employ administrators or communicators, especially if the organizations are engaged in highstakes consultations and are active in the media. Furthermore, the complexity in applying and managing time-limited projects (among them EU projects) paired with their potential economic opportunity has led to the need for organizations to search for new competences (Hedling and Meeuwisse 2015).

\section{A Domestically Embedded Elite}

In this study, we test the hypothesis that a privileged position in relation to the Swedish state increases the chances of Europeanization among Swedish CSOs. We do this by comparing patterns of EU engagement among an elite group with the whole sample of organizations in our survey $(\mathrm{N}=2,971)$.

In order to distinguish an elite group, we have considered three main criteria: privilege, proximity, and professionalization. We considered privilege as a question of public funding opportunities, and organizations that met the privilege criterion stated that they received more than 50 percent of their funding from the Swedish state. This criterion has certain consequences for our study. While popular movements have been known to be embedded in the Swedish corporatist model, some of them will not qualify for our selection because they remain largely membership funded. Our aim in this selection is to reflect the changing conditions of Swedish civil society and to capture potential new actors of domestic embeddedness. We treated proximity as a close connection to the Swedish state, and organizations that met the proximity criterion stated that they often or sometimes participated in the Swedish government's consultation procedures (also known as remiss procedures) in official reports of the Swedish government (SOU) or in government-assigned working committees. Finally, we considered professionalization as the shift from strictly voluntary engagement to professional resources, and organizations that met the professionalization 


\section{Table 5.1. The Three P's of Elite Criteria}

\begin{tabular}{lcc}
\hline & Percent & Total (N of analyzed cases) \\
Privilege & 15 & 2,509 \\
Proximity & 19 & 2,255 \\
Professionalization & 18 & 2,649 \\
Source: EUROCIV survey. & & \\
\hline
\end{tabular}

criterion stated that they had employed at least one person (any position equaling more than 0 percent). With these selection criteria, we were able to identify the group illustrated in table 5.1.

We found that 15 percent (381 organizations) of the total population met the privilege criteria, 19 percent (428 organizations) met the proximity criteria, and 18 percent (477 organizations) met the professionalization criteria. In a second step we were interested in the distribution of these elite characteristics among the organizations, as shown in table 5.2. We found that 63 percent of our population had none of the elite characteristics, while 25 percent had one of them and about 10 percent had two. Only 2 percent met all three criteria, amounting to 125 organizations.

The group of 125 seemingly embedded and favored organizations was hence of particular interest in testing the positive persistence hypothesis-in other words, the assumption that access at the domestic level increases organizational and participatory Europeanization.

\section{A New Model of Swedish Corporatism?}

Against the background of a Swedish civil society in transition, it is interesting to consider the organizations that enjoyed what we have called embedded positions, especially in comparison to traditional Swedish corporatism. Table 5.3 presents the different types of organizations and their representation in our elite group $(\mathrm{N}=125)$ compared to the general sample $(\mathrm{N}=$ 2,971).

\section{Table 5.2. Distribution of Elite Criteria}

\begin{tabular}{lcc}
\hline Number of characteristics & Percent & Total (non-weighted) \\
0 & 63 & 899 \\
1 & 25 & 710 \\
2 & 9 & 408 \\
3 & 2 & 125 \\
Source: EUROCIV survey. & & \\
\hline
\end{tabular}


Table 5.3. Types of Organizations

\begin{tabular}{lccc}
\hline & $\begin{array}{c}\text { Elite } \\
\text { (percent of } \\
\text { total) }\end{array}$ & $\begin{array}{c}\text { Nonelite } \\
\text { (percent of } \\
\text { total) }\end{array}$ & $\begin{array}{c}\text { Total (N of } \\
\text { analyzed cases) }\end{array}$ \\
\hline Interest organization & 53 & 40 & 41 \\
Lifestyle organization & 15 & 35 & 34 \\
Political organization & 21 & 6 & 6 \\
Solidarity organization & 4 & 7 & 7 \\
Religious organization & 2 & 11 & 11 \\
Service organization & 4 & 1 & 1 \\
Source: EUROCIV survey. & & &
\end{tabular}

We can see that interest organization is the major type in our group and slightly overrepresented compared to the nonelite and the general sample. Among interest organizations, trade unions do not meet all three of our criteria. In fact, they are almost entirely funded by membership fees even though they might be considered to be domestically embedded in many other aspects, and they are thus excluded here due to not meeting the funding criterion. Political organizations and service organizations are much more prominent in our elite group compared to the general sample whereas lifestyle organizations and religious organizations are represented to a much smaller degree. The large representation of interest organizations and political organizations is perhaps not surprising considering the traditional ties due to Swedish corporatism.

A closer look at the types of interest organizations, however, revealed another understanding of this group. Within the group of interest organizations, women's shelters and victim support organizations were the most prominent. Although characterized as interest organizations, they were to a large extent occupied with providing a service. Most of these organizations were founded in the 1980s, 1990s, or 2000s and are thus relatively new additions to Swedish civil society (Svensson 2007; Eriksson 2010). It could be argued that these organizations complement and strengthen the public sector in a weakening welfare state. In 2001 the Social Service Act was changed so that it states that the social services should provide help for victims of crime, especially for women and children who are victims of violence (Social Services Act 2001). A widespread solution for the social services to provide this help has been to refer these victims to women's shelters and victim support organizations that they support financially. The tendency to combine new models for help and support with lobbying is particularly apparent for women's shelters/crisis centers. This combination could also form a basis for claims of special knowledge and could be strategically used 
Table 5.4. Organizational Level

\begin{tabular}{lccc}
\hline & $\begin{array}{c}\text { Elite } \\
\text { (percent of } \\
\text { total) }\end{array}$ & $\begin{array}{c}\text { Nonelite } \\
\text { (percent of } \\
\text { total) }\end{array}$ & $\begin{array}{c}\text { Total (N of } \\
\text { analyzed cases) }\end{array}$ \\
\hline National & 30 & 10 & 10 \\
Regional & 28 & 6 & 7 \\
Local & 43 & 83 & 82 \\
Source: EUROCIV survey. & & & \\
\hline
\end{tabular}

by these actors in policy change processes and for political demands (Eriksson 2010). The other groups of organizations represented within the interest type were more familiar and fairly well-established disability organizations, immigrant organizations, substance abuse organizations, and lesbian, gay, bisexual, and transgender (LGBT) organizations.

Furthermore, the organizations in the elite group were found at all levels of activity but were to a larger extent national and regional organizations compared to the general sample (see table 5.4). This result is not surprising considering the criteria of proximity and professionalization. In line with the popular movement tradition, many Swedish interest organizations in the welfare area are organized at the national, regional, and local levels. Local organizations often rely on voluntary work, and political and administrative tasks are usually referred to the national associations that to an increasing degree employ professionals (Papakostas 2012).

\section{Positive Persistent Europeanization Patterns?}

In order to test the positive persistence hypothesis, we compared patterns of participatory and organizational Europeanization among our elite group with the general sample. In line with the understanding of participatory and organizational Europeanization, we focus on participation through membership in EU-level networks, participation through various activities at the EU level, and participation through different channels of EU political influence.

\section{Activity at the EU Level}

At first glance it certainly appears that the embedded elite group is Europeanized to a greater degree than the rest of our sample. When asked 
Table 5.5. Activity at Different Political Decision-Making Levels

\begin{tabular}{|c|c|c|c|c|}
\hline & $\begin{array}{l}\text { Elite } \\
\text { (percent of } \\
\text { total) }\end{array}$ & $\begin{array}{l}\text { Nonelite } \\
\text { (percent of } \\
\text { total) }\end{array}$ & Cramer's V & $\begin{array}{c}\text { Total ( } \mathrm{N} \text { of } \\
\text { analyzed cases) }\end{array}$ \\
\hline Local & 96 & 89 & n.s. & 2,622 \\
\hline Regional & 89 & 46 & $.123^{* * *}$ & 2,612 \\
\hline National & 72 & 26 & $.151^{* * *}$ & 2,603 \\
\hline Nordic & 36 & 10 & $.126^{* * *}$ & 2,561 \\
\hline European & 28 & 9 & $.098^{* * *}$ & 2,555 \\
\hline International & 27 & 14 & $.052^{* * *}$ & 2,564 \\
\hline \multicolumn{5}{|c|}{$\begin{array}{l}\text { Note: The measure of association between the variables is Cramer's V. }{ }^{*}=5 \text { percent, }{ }^{* *}=1 \\
\text { percent, and }{ }^{* * *}=0.1 \text { percent significance. } n . s .=\text { not significant. } \\
\text { Source: } \text { EUROCIV survey. }\end{array}$} \\
\hline
\end{tabular}

about the extent of the organization's activity at the European level, the elite group was seen to have three times higher levels of Europeanization. ${ }^{3} \mathrm{~A}$ similar pattern arises in relation to Nordic cooperation and internationalization. In fact, it appears that these organizations are overall more active than the general sample because they report higher frequencies of engagement at all political decision-making levels (the results in chapter 3 indicate a similar pattern). Only at the local/municipal level was the pattern nonsignificant because the numbers were just marginally higher for the elite group. This of course is a result that correlates with the distribution of organizational levels found in table 5.5, but it is intriguing that the elite group reports such widespread, flexible activity across all levels. It is notable, however, that even among the elite group the preferred transnational venue is still Nordic cooperation.

\section{Europeanization through EU-level Memberships}

The EU's attempts at institutionalizing civil society have led to the creation and development of numerous EU-level networks and umbrella organizations. These networks and organizations engage in both transnational cooperation in the member states and in exerting political influence aimed at EU decision-making. Some have become important links between EU institutions and civil society and derive legitimacy for their advocacy and lobbying activities by claiming broad representativeness (Johansson and Lee 2012). In the welfare area, these organizations often cluster in the Social Platform, the largest platform of European rights and value-based Civil Society Organizations (CSOs) working in the social sector (see chapter 2). It consists of forty-eight umbrella organizations representing more than 2,800 
Table 5.6. Memberships at the EU Level

\begin{tabular}{|c|c|c|c|c|}
\hline & $\begin{array}{l}\text { Elite } \\
\text { (percent of } \\
\text { total) }\end{array}$ & $\begin{array}{l}\text { Nonelite } \\
\text { (percent of } \\
\text { total) }\end{array}$ & Cramer's V & $\begin{array}{c}\text { Total ( } \mathrm{N} \text { of } \\
\text { analyzed cases) }\end{array}$ \\
\hline $\begin{array}{l}\text { Membership in network/ } \\
\text { federation/umbrella } \\
\text { organization at the } \\
\text { European level }\end{array}$ & 25 & 9 & $.082^{* * *}$ & 2,406 \\
\hline \multicolumn{5}{|c|}{$\begin{array}{l}\text { Note: The measure of association between the variables is Cramer's V. }{ }^{*}=5 \text { percent, }{ }^{* *}=1 \\
\text { percent, and }{ }^{* * *}=0.1 \text { percent significance. } n . s .=\text { not significant. } \\
\text { Source: } \text { EUROCIV survey. }\end{array}$} \\
\hline
\end{tabular}

national organizations and associations at local, regional, and national levels in the EU member states (Lee 2012). There are also a number of international organizations that have created sublevels specifically targeting EU politics. Participation in these organizations can be viewed as instances of Europeanization by association, but participation might also lead to cognitive processes of influence, framing, and sense of collectivity. The results in our study concerning membership at the EU level are presented in table 5.6.

Participation in EU-level networks and organizations was not widespread among the Swedish CSOs in our sample. Only 9 percent in the nonelite group stated that they held such memberships. However, such memberships were much more common among our domestically embedded elite organizations, of which 25 percent held an EU-level membership. (It was also rather common to hold memberships in international organizations.) The European NGO confederation for relief and development (CONCORD), the European Network Against Racism (ENAR), the European Anti-Poverty Network (EAPN), the European Disability Forum (EDF), the European Women's Lobby (EWL), and Caritas Europe are examples of European networks that were often mentioned. These organizations are all well established in the EU civil dialogue and are recognized as channels of influence in EU politics. However, as Johansson and Lee (2012) have demonstrated, these organizations rest on multilayered membership structures based on factors such as organizational types (service vs. advocacy organizations), geographical basis (European, national, regional, and local levels), and in some cases the degree of self-representation, thus making it hard to determine who they actually represent. Johansson and Lee (2012) unraveled long chains of representation and representational gaps between the European branches of EU-based CSOs and their national members and their wider constituencies. Even if they claim to represent a wide number of organizations and groups of individuals, a limited number of members might in practice exercise full participatory rights. 


\section{Europeanization through Participatory Activities}

While membership in EU-level networks provides for certain stability in EU engagement, membership can in reality entail different types and degrees of participation. To some organizations only a newsletter from the European umbrella organization demonstrates the membership. To others it has led to participation in transnational activities. These activities might not be restricted to members, but it is often through European membership that domestic organizations are invited to participate. When looking at the results of different types of participatory activities in table 5.7, the pattern of embedded privilege persists, and the elite group reports higher levels of participation in all types of EU-level activities.

Most common is participation in meetings and conferences organized by EU-level organizations, which was reported by more than a third of the domestically embedded CSOs compared to fewer than 10 percent in the rest of our sample. Furthermore, most Swedish CSOs seem to participate rather seldom in EU-funded transnational projects or campaigns led by organizations based in Brussels, but participation happens much more often among our domestically embedded elite (cf. chapter 3).

A closer look at the domestically embedded organizations that reported that they do indeed participate at the EU level indicates differences between different types of organizations and provides more-concrete information about the nature of the engagement. The CSOs that stand out by reporting strong participation at the European level are not the previously mentioned

\section{Table 5.7. Types of Participatory Activities}

\begin{tabular}{|c|c|c|c|c|}
\hline & $\begin{array}{l}\text { Elite } \\
\text { (percent of } \\
\text { total) }\end{array}$ & $\begin{array}{l}\text { Nonelite } \\
\text { (percent of } \\
\text { total) }\end{array}$ & Cramer's V & $\begin{array}{l}\text { Total }(\mathrm{N} \text { of } \\
\text { analyzed } \\
\text { cases })\end{array}$ \\
\hline $\begin{array}{l}\text { Meetings and conferences } \\
\text { organized by EU-level } \\
\text { organizations }\end{array}$ & 38 & 8 & $.148^{* * *}$ & 2,437 \\
\hline $\begin{array}{l}\text { EU-funded projects in } \\
\text { cooperation with other } \\
\text { European organizations }\end{array}$ & 16 & 4 & $.092^{* * *}$ & 2,363 \\
\hline $\begin{array}{l}\text { Campaigns led by } \\
\text { organizations based in } \\
\text { Brussels }\end{array}$ & 9 & 2 & $.084^{* * *}$ & 2,353 \\
\hline \multicolumn{5}{|c|}{$\begin{array}{l}\text { Note: The measure of association between the variables is Cramer's V. }{ }^{*}=5 \text { percent, }{ }^{* *}=1 \\
\text { percent, and }{ }^{* * *}=0.1 \text { percent significance. n.s. }=\text { not significant. } \\
\text { Source: } \text { EUROCIV survey. }\end{array}$} \\
\hline
\end{tabular}


service-providing women's shelters and victim-support organizations that have come to complement and strengthen the withdrawing Swedish welfare state. It is rather certain religious and humanitarian organizations, and some interest and cultural organizations-and to some degree also political parties-that were Europeanized in this sense. Most of them-but not all-operated at the national level, and many had appointed specific EU coordinators.

An organization that perhaps more than others signals Europeanization is The Way Out! (Vägen ut!), a set of cooperatives founded in 2002 as a result of an EQUAL Community Inititative project with the goal of introducing so-called social enterprises. The organizations that established themselves in the new social economy sector that emerged in Sweden beginning in the 1990s used the European concept to persuade actors and to gain influence in Swedish politics (see chapter 7 and Hedling and Meeuwisse 2015). It is thus hardly surprising that this cooperative reported frequent and various activities at the EU level.

These types of participatory activities also engaged organizations with much longer histories. The Swedish branch of the Pentecostal revival is an example of an embedded nonconformist religious organization with considerable EU engagement. As stated on their website, since the early 1900s Pentecostal churches have "worked together to build the kingdom of God-locally, regionally, nationally, and globally" (The Pentecostal Alliance of Independent Churches 2015). The church has a clear international profile (not least through missionary work in ninety countries, but also through membership in global organizations) and also appears to be an active member of CONCORD, The European Cooperative for Rural Development (EUCORD), and Voice (a European project for the sustainable development and innovation of choral singing) at the EU level. Furthermore, it had been engaged in EU-funded projects and it had its own professional EU coordinators.

IM (Individuell Människohjälp), a humanitarian organization founded in 1938, is another Swedish CSO with a religious background and international prospects. It aims at fighting poverty and exclusion and operates in ten countries worldwide (IM 2015). As was the case with the Pentecostal revival, it was a member of both global networks (e.g., the World Fair Trade Organization) and EU-level umbrella organizations (e.g., CONCORD, EAPN), had hired people with the task of managing the organization's relationship with the EU, and had on occasion been engaged in EU-funded projects. It also stated that it sometimes participated in campaigns led by organizations based in Brussels.

Among the domestically embedded interest organizations, participation at the EU level was mostly reported from some of the patient and 
disability organizations. For example, DHR (Delaktighet, Handlingskraft, Rörelsefrihet; an organization for people with impaired mobility) and the National Leukemia Association (Blodcancerförbundet) were both members of EU-level networks within their respective areas and stated that they from time to time took active part in conferences and campaigns. The same applied to a few stray cultural organizations, including the Swedish Workers' Theater Association (Sveriges Arbetarteaterförbund), which was an active member of both the international and the North European Amateur Theater Association, had participated in EU-funded projects, and had appointed EU coordinators.

Several of the political parties stated that they had participated in conferences organized by EU-level organizations and/or in campaigns led by organizations based in Brussels. Some also had EU coordinators. A common feature was that they stressed the political importance of knowing what is going on in the EU.

\section{Activities and Strategies of Policy Influence}

The positive persistence hypothesis also rests on the assumption that special access to domestic channels of influence plays an important role for the prospects of Europeanization. According to the literature on interest group insiders and outsiders, insiders are more likely to seek direct strategies such as contact with bureaucrats and politicians. Outsiders lack the privileged access to such direct political channels and are therefore more inclined to use indirect strategies such as mobilization or media campaigns (Maloney, Jordan, and McLaughlin 1994). There are numerous direct strategies through which Swedish CSOs could potentially have influence in matters of EU policy. Addressing the Swedish authorities, members of the European Parliament (MEPs), and the formal decision-making institutions are perhaps the most direct channels of political representation in the EU.

In order to consider strategies of influence at the EU level, it is first relevant to investigate if and how the organizations actually engage in policy-influencing activities (domestically as well as internationally). Table 5.8 presents the organizations' overall engagement in activities of policy influence. Advocacy and lobbying are activities that can be pursued through both direct and indirect strategies, while demonstrations are an indirect strategy. Again, we observe that the elite group organizations are more active in all types of activities. A large majority of the domestically embedded CSOs reported that they were engaged in advocacy and lobbying activities compared to fewer than half of the organizations in the nonelite group. It 
Table 5.8. Activities of Policy Influence

\begin{tabular}{|c|c|c|c|c|}
\hline & $\begin{array}{l}\text { Elite } \\
\text { (percent of } \\
\text { total) }\end{array}$ & $\begin{array}{l}\text { Nonelite } \\
\text { (percent of } \\
\text { total) }\end{array}$ & Cramer's V & $\begin{array}{c}\text { Total ( } \mathrm{N} \text { of } \\
\text { analyzed cases) }\end{array}$ \\
\hline Advocacy & 86 & 46 & $.118^{* * *}$ & 2,424 \\
\hline Lobbying & 89 & 38 & $.154^{* * *}$ & 2,390 \\
\hline Demonstrations & 28 & 13 & $.065^{* *}$ & 2,363 \\
\hline \multicolumn{5}{|c|}{$\begin{array}{l}\text { Note: The measure of association between the variables is Cramer's V. }{ }^{*}=5 \text { percent, }{ }^{* *}=1 \\
\text { percent, and }{ }^{* * *}=0.1 \text { percent significance. n.s. }=\text { not significant. } \\
\text { Source: } \text { EUROCIV survey. }\end{array}$} \\
\hline
\end{tabular}

was less common to use demonstrations among the elite group, but it was still a more common activity among that group than among the nonelite organizations. It is also worth noting that lobbying was the most often mentioned activity in the elite group, while advocacy was the most often mentioned activity in the nonelite group (although they do not use advocacy to the same degree as the elite group).

Moving to the European level, it is interesting to see how the high engagement in advocacy and lobbying activities among the domestically embedded CSOs is transformed into strategies of policy influence aimed at the EU. A common critique regarding the usefulness of the insider/ outsider dichotomy and the conceptualization of direct/indirect strategies is the argument that most organizations have both insider and outsider characteristics and use multiple strategies to influence policy (Binderkrantz 2005; Maloney, Jordan, and Mclaughlin 1994; Page 1999). In the case of the EU, it is also at times difficult to distinguish direct strategies from indirect strategies. Transnational mobilization of organizations associated with the Social Platform is an example of an indirect strategy that can be further pursued through the privileged partnership with the European Commission (EC). Furthermore, our previous study of EU engagement among Swedish civil society in the welfare area revealed that it was common to use key persons-influential and well-connected individuals who often had previous experience from representative roles in the EU (for instance, in the European Economic and Social Committee [EESC])-to obtain influence at the European level (Hedling and Meeuwisse 2015). These strategies could therefore be understood as semi-direct because they build on access to official channels, which in social movement research are often referred to as elite allies (cf. Tarrow 1994), compared to indirect strategies that are confined to an outside arena. ${ }^{4}$

Table 5.9 presents the use of direct or semi-direct strategies of EU influence among the organizations. The use of Swedish authorities to seek 


\begin{tabular}{|c|c|c|c|c|}
\hline & $\begin{array}{c}\text { Elite } \\
\text { (percent of } \\
\text { total) }\end{array}$ & $\begin{array}{c}\text { Nonelite } \\
\text { (percent of } \\
\text { total) }\end{array}$ & Cramer's V & $\begin{array}{c}\text { Total ( } \mathrm{N} \text { of } \\
\text { analyzed cases) }\end{array}$ \\
\hline $\begin{array}{c}\text { Use of Swedish } \\
\text { authorities }\end{array}$ & 57 & 13 & $.180^{* * *}$ & 2,352 \\
\hline Use of EP & 30 & 5 & $.158^{* * *}$ & 2,334 \\
\hline $\begin{array}{l}\text { Use of other EU } \\
\text { institutions }\end{array}$ & 14 & 2 & $.121^{* * *}$ & 2,319 \\
\hline $\begin{array}{l}\text { Use of EU } \\
\text { organizations }\end{array}$ & 16 & 4 & $.092^{* * *}$ & 2,305 \\
\hline $\begin{array}{c}\text { Use of international } \\
\text { organizations }\end{array}$ & 19 & 6 & $.079^{* * *}$ & 2,327 \\
\hline Use of key persons & 17 & 5 & $.080^{* * *}$ & 2,319 \\
\hline
\end{tabular}

influence in EU policy was the most common strategy among all the organizations but was a clearly preferred strategy in the elite group. A majority of the elite group organizations reported that they used the Swedish political channel as a means of having influence in the EU compared to just above a tenth of the organizations in the nonelite group. The pattern persists among other direct or semi-direct strategies of influence, including the use of European Parliament (contacts with MEPs), the use of other EU institutions (i.e., the EESC), the use of European-level organizations, the use of international organizations, and the use of key persons. Despite the clear indication that the elite group is a more frequent user of the direct and semi-direct channels of influence, apart from the use of Swedish authorities the engagement in EU policy influence is not very high. Most organizations did not use these strategies at all, and some indicated in the open questions of the survey that the EU was not perceived as a prioritized political level and was only remotely relevant to the organizations' activities.

Although these results largely support the belief that insider groups are more frequent users of direct strategies of influence, we also know from previous results that the organizations in our elite group are generally more active than the nonelite (see table 5.5). However, the preferred and frequent use of Swedish authorities as a means of influence compared to other strategies offers clear support to the positive persistence hypothesis and shows how Swedish CSOs are indeed actively using access granted through domestic embeddedness as a channel to EU politics. 


\section{Conclusions}

This chapter has discussed conditions for access to the EU level in a Swedish civil society in transition. The embedded elite that we have studied here represents a new group of insiders compared to the traditional Swedish corporatist model. Although women's shelters and victim support organizations stood out in our elite sample, they had relatively little EU engagement. It was instead certain religious and humanitarian organizations, some interest and cultural organizations, and to some degree some political parties that reported high levels of Europeanization. In this group it was more common to engage in European transnational activities and to seek influence at the European level. These attempts to have influence on European activities were foremost pursued through already established access points at the domestic level. The positive persistence hypothesis is hence supported in the context of Swedish CSOs in our sample.

Still, overall, the EU level is generating limited interest in Sweden. The Swedish level remains prioritized, and very few organizations reported high activity at the European level. In this sense, the Europeanization effects are still relatively low in Sweden compared to countries where civil society is largely directed toward EU funding opportunities (e.g., Eastern Europe). Sweden seems to remain a rather reluctant EU member state. Despite the decline in corporatism, there is still a privileged elite (although differently composed), and this elite expresses mixed feelings toward the EU. It is, however, possible that the Europeanization effects that we have witnessed here, although limited, are the first signs of a gradual adaptation to the new political reality among those with resources and access and that this trend will eventually follow in society at large.

Elsa Hedling is a $\mathrm{PhD}$ candidate at the Department of Political Science at Lund University, Sweden. Her research interests broadly lie in the intersection of EU politics, European integration, media, communication, and international relations. She has previously authored publications on the European Citizens' Initiative, the Europeanization of Swedish civil society, and Swedish foreign policy.

Anna Meeuwisse is Professor of Social Work at Lund University, Sweden. One of her research areas concerns the changing roles of CSOs in the welfare state. She has been engaged in several research projects regarding civil society, advocacy, and transnational social movements in the areas of health and welfare. 


\section{Notes}

1. This contradiction is perhaps especially true for Sweden, a country that has often been characterized as a political system charged with fewer elite mechanisms than many of its European neighbors. The lower level of elitism has, among other explanatory factors, been linked to the absence of a strong aristocracy, to Lutheran Protestantism, and to the prominence of popular movements (Berggren and Trägårdh 2015). The very existence of Swedish civil society is hence considered a counterforce to political elitism. To this day Sweden has maintained a political culture that often favors experience over competence, and the Swedish Parliament seats fewer elite politicians than most EU member states, although this is certainly an area undergoing significant changes (Dahl 2011).

2. People's involvement in civil society has been seen as a fundamental component of, and as essential for, democracy in Sweden (Jeppsson-Grassman 2004). Through civil society associations, individuals have a channel to exercise their political citizenship. Meanwhile, those associations serve as democracy schools where democratic values and ways of working are learned and reproduced (Amnå 2006).

3. In tables 5.5, 5.7 . 5.8 and 5.9 our numbers refer to positive responses of "often" or "sometimes" in the survey results.

4. This access is of course a sign of privilege in itself. One could therefore argue that it is a cause rather than a result of domestic embeddedness, but since we have operationalized the term "privilege" with regard to funding rather than access in this study, the idea that elite privilege leads to elite access is not a logical fallacy.

\section{References}

Åberg, Pelle. 2013. "Managing Expectations, Demands and Myths: Swedish Study Associations Caught Between Civil Society, the State and the Market." VOLUNTAS: International Journal of Voluntary and Nonprofit Organizations 24, no. 3: 537-58.

Amnå, Erik. 2006. "Still a Trustworthy Ally? Civil Society and the Transformation of Scandinavian Democracy." Journal of Civil Society 2, no. 1: 1-20.

- 2007. "Associational Life, Youth, and Political Capital Formation in Sweden: Historical Legacies and Contemporary Trends." In State and Civil Society in Northern Europe. The Swedish Model Reconsidered, edited by Lars Trägårdh, 165-204. New York, NY: Berghahn Books.

—. 2008. Jourhavande medborgare. Samhällsengagemang $i$ en folkrörelsestat. Lund, Sweden: Studentlitteratur.

Berggren, Henrik, and Lars Trägårdh. 2015. Är svensken människa? Gemenskap och oberoende i det moderna Sverige. Stockholm, Sweden: Norstedts.

Beyers, Jan. 2002. "Gaining and Seeking Access: The European Adaptation of Domestic Interest Associations." European Journal of Political Research 4: 585-612.

Binderkrantz, Anne. 2005. "Interest Group Strategies: Navigating between Privileged Access and Strategies of Pressure." Political Studies 53: 694-715.

Dahl, Svend. 2011 . "Efter folkrörelsepartiet: Om aktivism och politisk förändring i tre svenska riksdagspartier." PhD diss. Stockholm, Sweden: Department of Political Science, Stockholm University. 
Einarsson, Torbjörn, and Johan Hvenmark. 2012. "Efter medlemskapet?" In Civilsamhället $i$ samhällskontraktet, edited by Filip Wijkström, 71-92. Stockholm, Sweden: European Civil Society Press.

Eising, Rainer. 2007. "The Access of Business Interests to EU Enstitutions: Towards Elite Pluralism?" Journal of European Public Policy 14, no. 3: 384-403.

Eriksson, Maria. 2010. “Justice or Welfare? Nordic Women's Shelters and Children's Rights Organizations on Children Exposed to Violence." Journal of Scandinavian Studies in Criminology and Crime Prevention 11, no. 1: 66-85.

Fairbrass, Jenny, and Andrew Jordan. 2001. "Protecting Biodiversity in the European Union: National Barriers and European Opportunities." Journal of European Public Policy 8: 499-518.

Grant, Wyn. 1978. "Insider Groups, Outsider Groups and Interest Group Strategies in Britain." Working Party 19. Warwick, UK: University of Warwick Department of Politics.

—. 2000. "Pressure Groups and British Politics." Basingstoke, UK: Palgrave Macmillan.

Greenwood, Justin. 201 1. Interest Representation in the European Union. New York, NY: Palgrave Macmillan.

Hedling, Elsa, and Anna Meeuwisse. 2015. "Europeanize for Welfare? EU Engagement among Swedish Civil Society Organizations.” Journal of Civil Society 11, no. 1: 39-61.

Individuell Människohjälp (IM). 2015. “Individuell Människohjälp.” Retrieved 27 November 2015, from http://global.manniskohjalp.se/.

Jeppsson-Grassman, Eva. 2004. "Makt socialt kapital och hjälpgivande. Om kvinnor och män i civilsamhället.” In Genus och civilt samhälle, 15-35. Stockholm, Sweden: Swedish National Board of Health and Welfare.

Johansson, Håkan, and Sara Kalm. 2015. "Thinking Relationally: Questions, Themes and Perspectives for the Study of EU Civil Society." In EU Civil Society. Patterns of Cooperation, Competition and Conflict, edited by Håkan and Kalm, 1-20. Basingstoke, UK: Palgrave Macmillan.

Johansson, Håkan, Anders Kassman, and Roberto Scaramuzzino. 2011. Staten och det civila samhällets organisationer i ett föränderligt välfärdssamhälle. Stockholm, Sweden: Överenskommelsen.

Johansson, Håkan, and Mairon Johansson. 2012. "From a 'Liberal' to a 'Social democratic' welfare state: the translation of the English Compact into a Swedish context." Nonprofit Policy Forum 3, no. 2, article 6.

Johansson, Håkan, and Jayeon Lee. 2012. "Bridging the Gap: How do EU-Based Civil Society Organisations Acquire Their Internal Representation?" VOLUNTAS: International Journal of Voluntary and Nonprofit Organizations 25, no. 2: 405-24.

Karlberg, Eva, and Kerstin Jacobsson. 2014. "A Meta-organizational Perspective on the Europeanization of Civil Society: The Case of the Swedish Women's Lobby." VOLUNTAS: International Journal of Voluntary and Nonprofit Organizations 26, no. 4: 1438-59.

Keck, Margaret E., and Kathryn Sikkink. 1998. Activists beyond Borders: Advocacy Networks in International Politics. Ithaca, NY: Cornell University Press.

Lee, Jayeon. 2012. "The European Social Platform-Profile, membership and representation." EUROCIV Report 2012, no. 2.

Linde, Stig. 2010. "Församlingen i granskningssamhället." PhD diss. Lund, Sweden: Lund University. 
Lundberg, Erik. 2014. "A Pluralist State? Civil Society Organizations' Access to the Swedish Policy Process 1964-2009.” PhD diss. Örebro, Sweden: Örebro University,.

Lundström, Tommy, and Filip Wijkström. 1997. The Nonprofit Sector in Sweden. Manchester, UK: Manchester University Press.

Maloney, William A., Grant Jordan, and Andrew M. McLaughlin. 1994. "Interest Groups and Public Policy: The Insider/Outsider Model Revisited.” Journal of Public Policy 14: 17-38.

Marks, Gary, and Doug McAdam. 1996. "Social Movements and the Changing Structure of Political Opportunity in the European Union.” West European Politics 19, no. 2: $249-78$

Olsson, Lars-Erik, Marie Nordfeldt, Ola Larsson, and Jeremy Kendall. 2009. "Sweden: When Strong Third Sector Historical Roots Meet EU Policy Processes." In Handbook on Third Sector Policy in Europe-Multi-level Processes and Organized Civil Society, edited by Jeremy Kendall, 159-83. Cheltenham, UK: Edward Elgar.

Page, Edward C. 1999. "The Insider/Outsider Distinction: An Empirical Investigation.” British Journal of Politics and International Relations 1, no. 2: 205-14.

Papakostas, Apostolis. 2004. "Civilsamhällets rationaliseringar." Arkiv för studier i arbetarrörelsens historia 91: 19-45.

2011. "The Rationalization of Civil Society." Current Sociology 59, no. 1: 5-53.

. 2012. "De medlemslösa organisationernas tidevarv.” In Civilsamhället $i$ samhällskontraktet, edited by Filip Wijkström, 35-54. Stockholm: European Civil Society Press.

The Pentecostal Alliance of Independent Churches. 2015. The Swedish Pentecostal Movement. Retrieved 27 November 2015, from http://www.pingst.se/.

Pierson, Paul. 2000. "The Limits of Design: Explaining Institutional Origins and Change. Governance 13: 475-499.

Rothstein, Bo. 2001. "Social Capital in the Social Democratic Welfare State." Politics and Society 29, no. 2: 207-41.

Sánchez-Salgado, Rosa. 2010. "NGO Structural Adaptation to Funding Requirements and Prospects for Democracy: The Case of the European Union." Global Society 24, no. 2: 507-25.

Scaramuzzino, Roberto, Cecilia Heule, Håkan Johansson, and Anna Meeuwisse. 2010. EU och den ideella sektorn-En studie av det svenska Equalprogrammet. FoU Rapport 2010-2. Malmö: Malmö University.

Selle, Per, and Dag Wollebæk. 2010. "Why Social Democracy Is Not a Civil Society Regime in Norway." Journal of Political Ideologies 15, no. 3: 289-301.

Social Services Act. 2001. Svensk Författningssamling, 19 June, vol. 12, no. 453, 1-21.

Statistics Sweden. 2010. Det civila samhället 2010: Ett regeringsuppdrag med undersökningar från Statistiska centralbyrån. Örebro, Sweden: SCB.

Svensson, Kerstin. 2007. "Victim Support in a Changing Welfare State." Social Work and Society International Online Journal 5, no. 2: 123-134.

Tarrow, Sidney. 1994. Power in Movement: Social Movement, Collective Action and Politics. New York, NY: Cambridge University Press.

Warleigh, Alex. 2001. "Europeanizing Civil Society: NGOs as Agents of Political Socialization." Journal of Common Market Studies 39, no. 4: 619-63.

Wijkström, Filip. 2011. "Charity Speak and Business Talk': The On-Going (Re)hybridization of Civil Society." In Nordic Civil Society at a Cross-Roads. Transforming the 
Popular Movement Tradition, edited by Filip Wijkström and Anette Zimmer, 27-54. Baden-Baden, Germany: Nomos.

—, ed. 2012. Civilsamhället i samhällskontraktet. Stockholm, Sweden: European Civil Society Press.

Wijkström, Filip, and Torbjörn Einarsson. 2006 Från nationalstat till näringsliv? Det civila samhällets organisationsliv $i$ förändring. Stockholm, Sweden: Ekonomiska Forskningsinstitutet. 
This open access library edition is supported by the University of Lund. Not for resale. 
This open access library edition is supported by the University of Lund. Not for resale. 
Chapter 6

\title{
EUROPEANIZATION THROUGH FUNDING
}

\author{
Matteo Di Placido and Roberto Scaramuzzino
}

This chapter deals with European Union (EU) funding of Swedish civil society organizations CSOs. It is a case study of five organizations that have been granted funding through the European Social Fund ESF, and it explores the conditions and consequences of such funding. The financial support from the ESF is an example of financial Europeanization (as described in chapter 1) targeting both local and national CSOs that are active in the social welfare area. The ESF can in fact be seen as part of a common European approach on social welfare issues related to the Lisbon/Europe Treaty of 2020 (hereafter Lisbon/Europe 2020). The common social welfare agenda aimed at modernizing the social model of EU-members states and combating social exclusion. "This strategy is based on policies of anti-discrimination and labour-market integration and targets a range of disadvantaged groups" (Scaramuzzino 2012, 103-4).

To better understand financial Europeanization and its consequences for Swedish CSOs we will draw on two influential theories of political opportunity structures and resource mobilization in social movement research. These theoretical perspectives have a complementary role in describing, understanding, and explaining the dynamic and complex interactions between social structures and collective actors (McAdam, McCarthy, and Zald 1996).

First, the political opportunity structure approach rests on the idea that collective actors are shaped by the set of political constraints and 
opportunities that are part of the context in which they are embedded (McAdam, McCarthy, and Zald 1996). Second, the resource mobilization approach focuses on mobilization processes and on the formal organizational manifestations of these processes through so-called social movement organizations (cf. McCarthy and Zald 1977). Both the political opportunity structure and the resource mobilization approaches highlight the importance of context for explaining the mobilization of different groups, although resource mobilization theory is more focused on the collective actors that interact with the structures. Our theoretical framework also aligns itself to the attempt to combine top-down and bottom-up approaches in the study of Europeanization processes (see chapter 1).

As previous research on EU funding of national CSOs has shown (e.g., Sánchez-Salgado 2014a, 2014b; Scaramuzzino et al. 2010; Scaramuzzino 2012), such funding can be interpreted as a fundamental European governance instrument as well as a source for resource mobilization for many CSOs. Such processes of governance offer the possibility of redefining democratic mechanisms not merely on a representational level but also on a participatory level. However, these processes of governance can also be interpreted as a locus of co-optation in the sense that they contribute to the regulation of the activities of CSOs. This co-optation is achieved through conditions aimed at regulating the access, participation, and impact of the organizations (Sánchez-Salgado 2007, 2013, 2014a, 2014b; Scaramuzzino et al. 2010; Scaramuzzino 2012; ). Furthermore, within these processes CSOs interact not only with public authorities, such as the state or the EU, but also with other CSOs. In such collaborations, organizations with fewer resources and that are less embedded in the institutional context are often relegated to subordinated positions and become dependent on the support of public authorities or larger and more professionalized CSOs (Scaramuzzino et al. 2010; Scaramuzzino 2012).

Here we investigate public funding by the EU both as a source of opportunity for resource mobilization as well as a source of regulation through dependency and steering by the public authority. This relates to what Jacobsson and Johansson call "embedded agency" in chapter 1 of this volume. In other words, the question is whether the complex dynamic interactions between CSOs and the EU, which are based on financial support, can be considered as fertile ground for democratization and as supporting the development and flourishing of democracy from below, or instead as an expression of institutionalized coercive governance processes through which CSOs lose their innovative and democratic character.

The study presents results of a case study of five organizations running projects funded by the ESF and is based on qualitative interviews and relevant documents, including official documents by the ESF and their national 
translation in programming documents (e.g., ESF 2007), reports, and other material such as flyers and webpages. Semistructured interviews were carried out in the fall of 2014 with two officials from the Swedish ESF council (at the regional and national levels) and with five representatives of Swedish CSOs that received funding from the ESF during the programming period 2007-13. The organizations were selected through a search engine for the programming period 2007-13 that is available on the Swedish ESF council website (ESF 2014a).

The results of the study are furthermore compared with previous research conducted on the importance of the EQUAL Community Initiative, also funded by the ESF between 2001 and 2007 for Swedish CSOs (Scaramuzzino et al. 2010) and for Italian and Swedish immigrant organizations (Scaramuzzino 2012). By this comparison we aim to explore potential changes in the political opportunity structure of the ESF and in the resource mobilization strategies of Swedish CSOs that are receiving the funding. We will also discuss the relevance of the national context for how financial Europeanization affects domestic civil society.

\section{Public Funding of Swedish CSOs}

The results presented in chapter 3 by Scaramuzzino and Wennerhag show that Swedish CSOs are mainly financed through membership fees and by funding from municipal authorities. These findings are consistent with cross-national comparisons of the sources of revenue for CSOs. Data published in 2004 show that Swedish organizations have the highest level of reliance on membership fees in Europe and among the lowest dependency on public funding (Salamon, Sokolowski and List 2004, 33). As we have seen in chapter 3, EU funding seems to play an even less prominent role. However, we know from previous studies that this source of funding can play an important and even essential role for some CSOs (Scaramuzzino et al. 2010; Scaramuzzino 2012).

While the relative importance of public funding can be questioned if compared with other sources of funding and in international comparisons, the Swedish public sector over the years has built up a comprehensive and extensive system of funding that specifically targets CSOs. This system includes funding at the municipal, regional, and national levels and has traditionally privileged "membership organizations, where member activities and the importance of the movement for democracy are values often stressed, and where the measure of success and influence is a large body of members and widespread participation" (Lundström and Svedberg 2003, 224). Immigrant organizations, for example, have been granted funding 
on the basis of membership and representations at both the municipal and national levels (Scaramuzzino 2012). The underlying idea is that CSOs fill an intrinsic social need, and this is why the funding can be used relatively freely.

In addition to organizational funding, there are more performanceoriented funding opportunities that are often related to projects of different kinds. Project grants are distributed for specific purposes and activities and are limited by clearly defined project goals and time frames. While the organization grants thus mainly aim at generating effects on organizations, project grants are expected to have direct effects in terms of public benefit or for a specific target group (Danielson, Zetterberg, and Amnå 2009). Previous research has shown that project grants have become more frequent at the expense of organizational grants (Johansson 2005; Danielson, Zetterberg, and Amnå 2009).

As will be discussed later in this chapter, ESF funding is always linked to a specific project and might thus contribute to what has been described as the projectification of Swedish CSOs' activities (Hedling and Meeuwisse 2015 , 46). This development describes a shift of focus in the financial support system targeting CSOs from the earlier focus on organizational input in terms of membership, and thus a more representational and democratic role, to a more recent emphasis on output in terms of capacity to contribute to social development and welfare (cf. Danielson, Zetterberg, and Amnå 2009).

\section{The European Social Fund}

The history of European funds goes back to the first European programs of the 1970s and 1980s. The nature and the political role of European funding systems has progressively developed over time from being neutral to becoming strategically and politically oriented. A turning point in this process was the canceling of the program to combat social exclusion by the Court of Justice of the European Communities (CJEC). Since then the European Commission (EC) has been required to follow the rules of the European Economic Community and to be supervised by committees created for this purpose. A consequence of this development has been that strategic and political goals have been introduced into the European funding systems (Sánchez-Salgado 2010).

Within these processes behind the political reorientation of the European funding systems, the alignment of the ESF within other European strategies such as the European Employment Strategy (EES) and Lisbon/Europe 2020 strategy has been emphasized. The ESF has thus 
been understood as both a financial tool that is able to facilitate and amplify national changes in line with the EES (Weishaupt 2009) and as a political tool aimed at implementing the Lisbon/Europe 2020 priorities on employment at the domestic level (Sánchez-Salgado 2013).

The role of the structural funds in implementing the revised Lisbon strategy has been highlighted in previous studies (Hartwig 2007; Mendez 2011 ), mainly with regard to European institutional arrangements and programming documents (Sánchez-Salgado 2013). Few studies have addressed the translation of the ESF into domestic agendas (Verschraegen, Vanherck, and Verpoortenet 2011). The results of these studies suggest an impact on national policies by even modest ESF funding (Sánchez-Salgado 2013, 3), and there are indications that the European funding system functions as a (soft) governance tool for the EU.

Some argue that, as a political tool, ESF funding facilitates the practical implementation of the Lisbon/Europe 2020 goals on employment because through such funding the European priorities are both translated into national programming documents and practically implemented at the local level (Sánchez-Salgado 2013). Sánchez-Salgado (2013) emphasizes how despite a tendency of member states to support their own policy preferences, the EC's officials can make use of the Lisbon/Europe 2020 goals to promote the EC's priorities. But she also shows how the practical implementation of European priorities primarily rests on the degree of European pressure, on the EC's monitoring capacity, and on other facilitating factors such as national and local contextual features identified at the level of economic development and administrative centralization (Sánchez-Salgado 2013). In fact, "when European goals remain broad or ambiguous, the ESF has been mainly used to pursue the agenda of domestic actors" (Sánchez-Salgado 2013, 22).

It has been argued that EU funding supports the interests of disadvantaged groups and thus addresses certain imbalances in the system of interest representation. In this respect the EU funding of CSOs in the social welfare area tends to resemble the model of associative democracy. More specifically, on the one hand it tends to support many groups that voice the concerns of excluded citizens, while on the other hand it ensures effective and open representation of those groups that fulfill certain normative criteria and certain features such as representativeness and autonomy. According to this perspective, high dependency on EU funding does not necessarily mean lack of autonomy for European CSOs. It can, however, be related to a bureaucratization of politics (Sánchez-Salgado 2014a).

All in all, although it is clear that the EU, through its funding opportunities, has shaped the landscape of civil society at both the EU and domestic levels, this has not necessarily meant a loss of autonomy for the CSOs that have become dependent on public funding from the EU. The effects of EU 
funding have not been homogeneous across countries, policy areas, and types of CSOs, which seems logical considering the intrinsic diversity of the civil society sector (Sánchez-Salgado 2014b).

\section{The EQUAL Community Initiative}

The EQUAL Community Initiative was part of the ESF for the programming period 2001-7. The goal of EQUAL was to tackle discrimination and disadvantage in the labor market. According to the guidelines of the EC, these goals had to be met through projects implemented following the principles of partnership and empowerment, the latter being an early formulation of the principle of shared management. Hence, the principles of partnership and empowerment aimed at allowing and increasing the involvement of CSOs in projects within the social welfare area and fostering the economic and organizational development of CSOs (Scaramuzzino et al. 2010).

Almost 650 organizations were involved in the Swedish EQUAL program, and among the participants the majority were public organizations while significantly fewer were nonstate actors. Among these nonstate actors a larger share was represented by CSOs compared to for-profit organizations. In this respect, we find significant differences between the Swedish program and similar programs in other European countries. In most countries, CSOs were in the majority and public organizations in the minority. All country programs were similar in terms of the limited participation of for-profit organizations. Arguably, the Swedish program was marked by the prominent role of public organizations in labor market programs, a role that included the main responsibility for service production and provision.

However, within development partnerships promoted by the EC in the EQUAL Community Initiative, cooperation between public, private, and voluntary organizations was highly encouraged. A study of the CSOs participating in the Swedish EQUAL program (Scaramuzzino et al. 2010) shows that the program managed to attract a variety of organizations such as the women's movement, immigrant organizations, organizations representing people with disabilities, the Church of Sweden, and other religious organizations. Most CSOs represented the social partners (e.g., national, regional, or local unions) or interest groups for socially excluded or discriminated groups in society. This is hardly surprising since the EQUAL program aimed at bringing people back into the labor market.

The reasons why organizations participated in the EQUAL program varied greatly. Some aligned themselves to the formal objectives of the program and tried to include unemployed people in the labor market, while others mainly participated as a way to create goodwill for their organizations. Another 
key reason was to gain financial support. Even though public organizations tended to dominate the Swedish EQUAL program, it provided CSOs with ample financial support. However, desirable positions within partnerships (e.g., to be coordinators and/or the organization controlling the finances within the partnership) were mainly held by public organizations. In some cases this appeared to be part of an intentional strategy, while in other cases it was a response to expectations from the ESF. Public organizations functioned as a guarantee for a certain degree of organizational, financial, and administrative stability within partnerships (Scaramuzzino et al. 2010).

Although these positions were generally held by public organizations, some smaller user organizations were highly successful in taking advantage of opportunities within the program. They developed the general competence for running different EU projects and the administrative capacity to coordinate projects involving several different partners; they also managed to exercise influence in the partnerships they participated in. These organizations gained a lot from participating in the EQUAL program and increased their position vis-á-vis other CSOs (Scaramuzzino et al. 2010).

A comparison of immigrant organizations' participation in the Italian and Swedish EQUAL programs also showed that the programs in both countries had been able to stimulate projects at the national and local levels. The activities were similar even if the methods and the target groups were sometimes different, mirroring the different migratory systems in which the two countries were embedded. This suggests that the EQUAL program to a certain extent contributed to a Europeanization of the national civil societies and of the national social and integration policies in Italy and Sweden (Scaramuzzino 2012).

The model of development partnerships, however, exposed many small CSOs to the risk of being relegated to inferior positions within the partnership. Competition regarding positions of coordination and financial management often meant that leading positions within the partnership were held by public organizations in Sweden and by large CSOs in Italy (Scaramuzzino 2012). Seldom were such positions held by small CSOs (see also Sánchez-Salgado 2007). Both Italian and Swedish immigrant organizations were thus dependent on stronger actors to be able to access the EU funding. Furthermore, organizational properties and capacities seemed to play a fundamental role concerning immigrant organizations' ability to profitably and strategically mobilize resources and get access to opportunities (Scaramuzzino 2012).

The well-developed Swedish system of public subsidies seemed to give Swedish immigrant organizations a certain advantage compared to immigrant organizations in Italy that were to a higher degree dependent on the support of larger CSOs that were part of the labor or Catholic movements. 
Most organizations perceived the administrative burden of handling EU funding as overwhelming, but participation also provided opportunities to run projects and activities that would otherwise be impossible with domestic funding available. This was due to the lack of domestic funding (especially with regard to Italy) and to the state's lack of interest in the knowledge and expertise that immigrant organizations wanted to contribute with (especially with regard to Sweden) (Scaramuzzino 2012).

While the EQUAL Community Initiative was not repeated after 2007, the ESF has continued funding projects, also involving CSOs, in the areas of labor market integration and social exclusion.

\section{Experiences of ESF Funding}

The ESF Swedish website states that the fund is defined as "the European Union's main tool to help both young and older workers and job seekers. . . . The fund supports measures to prevent and combat unemployment, to promote training and to improve the way the labor market functions" (ESF 2014). The site furthermore describes ESF as a means "to achieve a high level of employment, equality between men and women, sustainable development and economic and social cohesion" (ESF 2014b) in partnership with the EU and member states. The ESF in Sweden, in line with the regulations and the national structural fund program for the period 2007-13, had the main role of concretely implementing the EES.

Between 2007 and 2013 the ESF granted 67 billion euros to projects across the entire EU. Of these funds, approximately 690 million euros were distributed in Sweden (ESF 2014b). The ESF in Sweden financed projects focused on skill provision by increasing opportunities for development and renewal within a person's working life through competence development; it also focused on labor supply by increasing job opportunities. The main focus of both kinds of projects was to use unconventional methods to increase the inclusion of discriminated groups such as immigrants, the unemployed, women, and youth in the labor market.

The following section presents the results of our more recent study focusing on five Swedish CSOs' experiences of running projects with funding from the ESF.

\section{Opportunities and Obstacles}

The five organizations reported quite different organizational motives and strategies behind their decision to apply for ESF funding, which is in 
line with previous research on the EQUAL program (Scaramuzzino et al. 2010). To the question, "Why did your organization decide to apply for ESF funds?," one interviewee answered, "It was just to see what possibilities it might present." This shows how the ESF is perceived as a possibility or opportunity. Often this perceived opportunity was articulated in terms of developing new working strategies and methods that the organizations would not otherwise have had the chance to implement. One informant stressed ESF funding as a unique opportunity: "There is no other way to get this kind of funding for labor market projects in Sweden. A lot of other organizations say, 'We finance everything except for that.' So you don't really have any choice. So Swedish funds and the municipalities don't really fund these kinds of things because they know there is the ESF . . . so in that way it is the only possibility, but it's a big one." One informant emphasized how there was little room for innovation and experimentation in everyday organizational work, which contrasts with the traditional view of Swedish CSOs' role in the welfare system as innovators and watchdogs (Olsson et al. 2009). However, once the new working strategies or methods proved successful, the organization had the chance to implement those within its regular activities, thus contributing to the development of the organization.

Concerning the reasons behind the decision to apply for ESF funding, another informant, who had the role of project leader, reasoned as follows: "There are always dual purposes. One is concerned with society and the other with one's own organization. And of course it's very nice to have new fresh resources and new fresh staff. And I think, one reason here was that X and others were hoping that this project should inspire and have an impact on their own organization and also put social economy on the map. And parallel to this, $\mathrm{X}$ together with $\mathrm{Y}$ were also setting up regional networks for social economy. So, of course, there are dual interests." Here several competing interests or reasons to access the ESF are mentioned-both to promote one's own organization and to achieve societal change by advocating for social economy as a concept and as a practice within a Swedish region.

Another very pragmatic reason emerged from the need, as underlined in one of the interviews, to finance the organization when there was no stable funding available for the activities. This meant that the organization had to seek out funding every time a project ended in order to keep its activities running. As the informant put it, "We don't have any yearly funding for our organization so we have to apply for funding every year, for every new idea." The funding could be local, national, or European, as in the case of the ESF, and there was a predominance of public financing compared to other sources. The same informant continued by emphasizing that, in addition to a desire to test a new idea, the organization had previous knowledge of working with EU funding. Hence there was an awareness of the possibilities 
connected with it: "We have been working with EU funding before so we know what possibilities come with it." In fact, as will be apparent in the following, knowledge concerning the system of rules and requirements was a critical point in strategically relating to and applying for funds from the ESF.

In line with previous research, the interviews indicated that the administrative burden was in general perceived as a challenge by the organizations. The difficulty to meet the administrative requirements that the funding implied was acknowledged in both of the interviews with the Swedish ESF officials and in all of the interviews with the representatives of the organizations.

The two ESF officials had different approaches to the administrative burden. While the regional office representative argued for the need to simplify the procedures to access and work with the ESF, the national office representative emphasized that smaller organizations, without the capacity to manage the fund's requirements, were not the target of the ESF. The informant argued, "The ESF... it's not a fund you are entitled to. It's a fund you are applying to in competition with others." The informant further emphasized how the administrative burden was not an exclusive problem for CSOs but was also felt by private and public organizations. What perhaps differed, according to the informant, was the financial stability needed to competently face such an administrative burden, which most public and private organizations possessed. Finally, the informant emphasized that the organizations that could not manage the financial grant in the way required by the fund should avoid applying for funding or, as an alternative, should try to apply in partnership with stronger organizations that could take on the role of project owner and be a guarantor of a certain level of stability.

The logic of the administrative burden can thus be seen both as an obstacle viewed from below and as a selection criterion viewed from above. However, the informant also stated, "You need to have some sort of project administration capacity. But that doesn't mean that you are supposed to crush those small [associations]. You can run an umbrella project having these small associations as your co-partners." This translates into a practice that promotes already established and strong organizations and a process toward "participatory democracy of professionals" (Sánchez-Salgado 2010, 527), which resembles bureaucratic and business organizational models. One might argue that such conditions for participation fail to promote a broader conception of democracy.

The administrative requirements were considered especially burdensome by small organizations, where the staff was usually involved on a voluntary basis and not trained to handle a vast array of bureaucratic duties. As an informant put it: 
The obstacles were with the administration of the project, but it also helped us to think about what we were doing, because we were writing those reports every month. They checked us a lot, so it also helped to guarantee some quality, but still it took a lot of time from the work that we were supposed to do. We didn't have other people to rely on. Our projects were kind of small in that sense, we were two people working with a lot of different stuff, so all those administrative things took time from actually running the real activities.

Yet other informants mentioned that the administrative burden, rather than representing a barrier for the organizations' ability to relate to the ESF requirements, was demanding because it required a lot of time to deal with. These representatives recognized the fact that their organizations had the necessary organizational capacity to competently face the administrative requirements, something smaller organizations might not have. As an informant mentioned, "But sometimes I feel like most of my time went to the bureaucracy, and we have a big organization. I don't know how that could be for smaller organizations."

Hence the perceived possibility to handle the guidelines was related to the resources in terms of administrative skills that the organizations possessed. An informant stressed the impossibility for an organization to properly deal with the administrative requirements if there was nobody in the organization with specific knowledge on how to accomplish the tasks.

The monitoring of the projects by the ESF was also criticized by some organizations. One of the representatives emphasized how the main focus of the ESF was on checking the organizations' use of money and other formalities (such as the number of hours of all of the participants in the projects reported through daily forms to be filled out by the organization) rather than on the effects of the project and its actual implementation. Another informant had a more positive view, saying that the systems of checks and rules was actually reasonable and aimed at guaranteeing that the projects provided high-quality services.

Another informant mentioned as a difficulty that the ESF guidelines and requirements forced the organization to change its initial plan for the project. The complex system of funding was challenging, especially if the organization aimed to work with smaller target groups. The impression given in the interview was that the funding system, through administrative constraints, tended to shape the projects. This might suggest mission drift among CSOs due to their dependency on EU resources. However, other informants claimed that the ESF rules, even if not problem-free, offered the possibility for the organizations to push their own agendas rather than being forced to adopt a specific stance.

The principle of cofinancing as a potential source of anxiety for the organizations involved in the projects was also mentioned by several interviewees, 
including the representative of the ESF national office. Public organizations such as labor market agencies or municipalities, who often were the guarantor of the cofinancing of the projects, could in fact at any time change their mind and leave the other organizations in a situation where it could not carry out the projects. One informant stressed that the practical implications of the requirement of cofinancing were that CSOs became dependent on partnerships with public organizations. Public organizations instead did not necessarily need to involve other organizations such as CSOs when applying for ESF funding, considering their ability to cover their share required by the principle of cofinancing. This would not have been possible according to the partnership model of the EQUAL Community Initiative.

The economic capacity of the organizations was identified as a further concern, especially for small organizations. One informant underlined how having a fluid economy was a main concern for the organizations leading the projects: "Who can be a project owner? A small association? Of course not. Only strong associations." Hence, the economy of a given organization seemed to influence its positioning within the partnership, as has also been shown regarding the EQUAL programs (Sánchez-Salgado 2007, 2014a; Scaramuzzino et al. 2010; Scaramuzzino 2012) and the ESF in general (Sánchez-Salgado 2013, 2014b). Small organizations were practically incapable of assuming the role of project owners because the economic requirements and the risks intrinsic to the management of the project worked as barriers. As one informant put it, the project owner was supposed to guarantee a certain financial stability, manage the payment of the staff, hire new staff if necessary, coordinate the partners, and guide all the other activities that were part of the project.

Another factor that was challenging for some of the organizations was the difference in terms of ideology and values between the organization and the ESF, which echoes the discussion on the alleged mismatch between the values underpinning the Swedish welfare system and the dominant ideological stances of the EU (see the introduction, this volume). This specific challenge forced the organizations to creatively bridge this ideological distance. As one informant commented on the topic, "We could have found out what they wanted, but we didn't agree with their view on things. Their definitions were sometimes based on values that were different than ours. We adopted a little bit of what the funders wanted, but at the same time we did it our own way, so we were still really running the projects like we wanted to."

However, not all the informants agreed on this point. One participant described the relative adaptability of the ESF to the many different ideological stances represented by different projects. The strategies used by the organization to overcome what here has been called an ideological distance will be discussed in the next part of the analysis. 


\section{Consequences: Outputs and Impacts}

Some informants described how the overall aim and nature of the organization had not been highly impacted by the ESF. Managing the project, however, had required some adjustments. On the one hand, the organizations were able to maintain their autonomy and pursue their aims; on the other hand, they often had to account for some deviations in their original intentions. For instance, one informant referred to the need to adjust the organization's target group to the very specific target groups advocated by the ESF. The organization had avoided this problem by defining two target groups in the project-one in line with the organization's nature and aims and the other following the ESF's guidelines. As the informant stated, "We did what they asked for, but we also added new things to our projects in order to do what we actually wanted to do. For instance, adding new target groups that they didn't ask for." Another informant described how the ESF guidelines and demands influenced the project and significantly shaped it:

And in the end the project became bigger. We had more target groups in the project than we had thought of from the beginning. And that has much to do with the guidelines from the ESF and how the program is built because it's hard within this program to work with very small groups of people because the funding for small projects is not enough to cover the costs. So you have to add more people, more target groups, and more partners and bigger regions. At least this was the case when we applied. So the ESF guidelines and demands significantly changed the project's character.

The ESF representative for the Swedish national council admitted that the ESF did in fact privilege big projects with broader impacts rather than small projects. This was also in line with the idea that the funding should be directed to organizations with certain resources and capabilities. The informant also stressed the ESF as a tool to foster a new role for the civil society sector within the framework of a changing welfare system. The role of the sector was described not as an alternative to the public in service provision, but as a complementary role that covered areas neglected by the public service. There was also an ambition of supporting CSOs' capacity building in order to make them more sustainable.

In reference to the lasting impact of the ESF on the organizations' activities, methods, and identities, some informants described how the ESF funding had indeed affected the development, methods, and activities of the organization even after the project ended. For instance, some reported that the main activities within the projects' framework had been integrated into the organization's regular activities, showing a lasting impact of the 
ESF within the organization itself. In some cases, the projects even brought about the establishment of new organizations as a means to tackle problems and deal with issues. However, these positive statements referred to wellestablished organizations.

A project leader from a strong, public-funded organization explained how the project had resulted in new working methods and had led to the implementation of new projects in collaboration with the local employment office. The informant also emphasized how this positive outcome could also be part of the experience of smaller organizations when they worked in partnership with stronger organizations. The informant listed a number of advantages that came as a result of involvement in an ESF project, namely new collaborations and partners with whom the organization currently worked, the acquisition of a different focus on how to work with labor-market issues, the development of new ideas about starting new social enterprises, and the development of new competencies in how to deal with projects. The interviewee also stated that it would not have been possible to access the ESF without economic resources despite having a good understanding of the system. The only other viable way would have been through a partnership with a stronger organization.

Most of those interviewed represented CSOs working closely with other CSOs, private organizations, and public organizations. In the EQUAL Community Initiative cooperation among public and private and voluntary organizations was highly encouraged, with partnership being a formal prerequisite to apply for funding. However, as shown by previous research on the EQUAL program in Sweden (Scaramuzzino et al. 2010), the partnership format exposed many small CSOs to the risk of being relegated to inferior positions within the partnership. Leading positions within the partnerships were often held by public organizations, and small organizations played a more marginal role (Sánchez-Salgado 2007). However, evidence also suggests that these very same organizations still might have enlarged their networks and become more established in the local context by engaging in such partnerships (Scaramuzzino 2012).

When asked about why the partnership model had not been implemented in the following programming period, the representative of the national office of the ESF council stated that this was due to these types of development partnerships being time consuming and challenging for the organizations. Instead, the networking dimension had been transferred from the project design to the political level thanks to the creation of the eight Structural Fund Partnerships corresponding to the eight regional plan areas of the national ESF program. These eight partnerships comprised key representatives of the local governance milieu such as politicians and CSOs, which facilitated common national and regional prioritization among 
regional growth policy, labor market policy, and the EU's cohesion policy. In other words, the Structural Fund Partnerships had the role of deciding which applications were to be granted in the specific region according to the national requirements and specifically the regional programming plan.

As it emerged from some of the interviews, working with ESF and in particular within a partnership was not problem-free. It implied stressful working conditions for the staff involved:

For us working with a project at higher level, it was a lot of work. It totally drained us sometimes, and it caused conflicts within our group.... To work with this big project implied a lot of people, a lot of administration, a lot of rules, and a lot of controlling from the ESF. Many, many questions, so of course it's not always easy. And when you have $\mathrm{H}$ sitting twenty kilometers from here, and we have to send papers, to call each other, to take a call from the ESF. It's not easy to work like that if you are not employed at the same place. It's a collaboration, and you have different roles, but they are still interconnected. She cannot do her work without the information from me and vice versa. So that's not easy. We have not had conflicts to the point that we didn't talk to each other, but of course you could get mad at each other, "Why didn't you do that?" Or maybe you misunderstand each other.

Another informant mentioned how the dialogue with public partners such as the employment agency was often challenging and led the organization to develop the project in another direction: "Work in partnerships is not always easy, so the organization decided not to further develop contacts with the public sector." However, conflicts in working together not only arose among different organizations but also among the hired staff for a specific project and the organizations' members. Some projects became centered on certain individuals because their specific social networks, competencies, and visions were particularly important to the development of the projects. The ability of individuals to competently make use of their professional network was recognized as fundamental when speaking about the development and implementation of certain projects. One interviewee claimed that the particular relationship built between her and the ESF representatives guaranteed easier implementation of the project. Another informant described how her background in the political arena, as for many of her colleagues in the civil society sector, greatly helped in reading the ESF requirement and in writing the application.

Furthermore, the personal background, whether as policymaker, democracy advocate, or academic student, was often mentioned as an essential competence in interactions with the ESF. Finally, one informant mentioned how the selection of the people involved in the project played a central role not only in its implementation but also in the creation of a social enterprise 
as an outcome of the project. She further stressed the importance of a good relationship between the persons engaging in the project and the ESF. During the project period, the ESF had provided support and guidance in times of need: "As long as you are part of the project you have different kinds of support, and everybody wants it to continue if it's a good project." The interviewee, however, also described a total lack of support after the project-period experied and, as she put it, being "left absolutely alone."

Being able to cooperate and build relationships with other actors was stressed as one of the most important preconditions for running an ESF project, as explained by one interviewee: "It was hard work. And I think that it's very much about building up relationships that are stable and trustful. If people are to do something together, the most important thing is that you have a good relation with the people you are supposed to work with that is founded in trust, safety, and honesty. And to have an idea about what you want to do together, so you have the same vision. The vision should be very clear. 'What is your vision?' That's the main thing." This quotation shows that financial Europeanization might also trigger cooperative dynamics in the landscape of Swedish CSOs. The collaborative feature of ESF funding seems not to have disappeared with the principle of partnership even if as previously discussed such collaboration has often changed some of the dynamics in the relationships between the organizations.

\section{Conclusions}

Among Swedish CSOs financial Europeanization is not particularly widespread, as shown by the survey-study presented in chapter 3 , and it does not seem to replace other forms of public funding. The EUROCIV survey also shows that CSOs that mobilize resources from the EU are not necessarily dependent on the EU for their survival. However, the qualitative case study presented here gives a more nuanced image through the interviews with public officials and with civil society representatives. In fact, our study shows that EU funding makes it possible for Swedish CSOs to run certain activities that are not easily financed through public authorities at domestic levels. In this sense, the ESF is a political opportunity structure that Swedish organizations can use to complement their domestic opportunities and can help them to diversify their sources of funding.

The funding from the ESF represents only a portion of the total funding that is available for active labor-market provisions in the European countries, and previous studies (Scaramuzzino et al. 2010) show that in the Swedish case the ESF represents a very small share (2.8 percent in 2006) of the national financing. Many of these domestic resources are of course 
not accessible for CSOs but are rather controlled by public organizations that have the main responsibility for the active provision of labor-market services. Still, it means that EU funding has relatively little significance for the implementation of labor-market policies in Sweden. In other countries where EU funding plays a much more prominent role due to lack of funding at the domestic level, the impact of financial Europeanization and the regulatory effect of the funding could be much more significant. The same goes for countries where general funding for CSOs is scarce and where there is strong competition among nonstate actors.

WhileSwedish CSOs seem to be strategically adapting to the requirements of the ESF in mobilizing resources, our study also suggests that they are not giving up their autonomy or their original mission. Hence the structuring effect of financial Europeanization does not seem to apply to the individual organizations that are getting the funding. There are good grounds, however, to claim that the ESF has a structuring effect on the landscape of CSOs because it clearly addresses certain types of resource-rich organizations that have access to administrative skills. This might trigger an elitization of Swedish civil society, as suggested by Hedling and Meeuwisse in chapter 5 of this volume. In fact, while financial Europeanization might provide the opportunity to strengthen the role of civil society as an innovator, it also seems to put weaker organizations in a position of dependency toward public organizations. The intermediary role of Swedish public organizations between domestic CSOs and European public institutions is evident when it comes to financial Europeanization, which is consistent with a similar role played by public institutions for regulatory Europeanization, as shown in chapter 3.

Our results suggest continuity rather than change in the role of EU funding for Swedish CSOs when compared with the previous studies on the EQUAL programs. This continuity suggests that EU funding has become a relatively stable and predictable opportunity structure for Swedish CSOs. The most significant change is related to the partnership model that is no longer used. In EQUAL, this model provided a tool for cooperation in which the partners were at least formally equal and their relationships were regulated and formalized in the application. Our results suggest that the new model might strengthen power relations within civil society and might strengthen the dependency on public organizations' intermediary role because the selection based on skills and resources tends to weed out smaller organizations or to put them in a position of direct dependency on other stronger organizations' goodwill. This selection of organizations seems to have gone from being a side effect of the ESF's requirements to a more explicit strategy for guaranteeing quality and the continuity of the projects. It might, however, also strengthen the structuring effect of financial Europeanization for domestic CSOs. 
Matteo Di Placido is a $\mathrm{PhD}$ candidate at the University of Milano-Bicocca, Italy at the Department of Sociology and Social Research, within the international doctoral program Analysis of Social and Economic Processes (ASEP). He was involved in the study of the Europeanization of Swedish civil society as part of his master program at the Faculty of Social Sciences at Lund University.

Roberto Scaramuzzino is Researcher at Lund University, Sweden. His research interests include changes in the welfare and integration systems and the role of CSOs in different countries. He has been engaged in comparative studies of mobilization in the migration and prostitution policy fields in Sweden and Italy, and at the EU-level. He is currently working in a research program on civil society elites in Europe.

\section{References}

Danielson, Anna, Pär Zetterberg, and Erik Amnå. 2009. Bidrag till vad?-En kunskapsöversikt över effekter och metoder rörande statliga bidrag till ideella organisationer. Stockholm, Sweden: Ungdomsstyrelsen.

ESF. 2007. National structural fund programme for regional competitiveness and employment (ESF) 2007-2013. Retrieved 2 August 2018, from https://www.esf.se/ Documents/In\%20english/National\%20structural\%20fund\%20programme\%20 for\%20regional\%20competitiveness\%20and\%20employment.pdf.

—. 2014a. Våra fonder. Retrieved 10 October 2014, from http://www.esf.se/sv/ Vara-fonder/Socialfonden-2007-2013/.

—. 2014b. The European Social Fund. Retrieved 5 May 2014, from http://www.esf.se/ sv/english/Our-programmes/The-European-Social-Fund/.

Hartwig., Ines. 2007. "European Employment Strategy and the Structural Funds: Spillovers towards Communitarisation?” In Economic Government of the EU. A Balance Sheet of New Modes of Policy Coordination, edited by Ingo Linsenmann, Cristoph O. Meyer, and Wolfgang T. Wessels, 1 19-140. Basingstoke, UK: Palgrave Macmillan.

Hedling, Elsa, and Anna Meeuwisse. 2015. "Europeanize for Welfare? EU Engagement among Swedish Civil Society Organizations." Journal of Civil Society 1 1, no. 1:39-61.

Johansson, Staffan. 2005. Ideella mål med offentliga medel-Förändrade förutsättningar för ideell välfärd. Stockholm, Sweden: Sober Förlag.

Lundström, Tommy, and Lars Svedberg. 2003. "The Voluntary Sector in a Social Democratic Welfare State: The Case of Sweden.” Journal of Social Policy 32, no. 2: 217-38.

McAdam, Doug, John D. McCarthy, and Mayer Zald. 1996. "Introduction: Opportunities, Mobilizing Structures, and Framing Processes: Toward a Synthetic, Comparative Perspective on Social Movements." In Comparative Perspectives on Social Movements: Political Opportunities, Mobilizing Structures, and Cultural Framings, edited by Doug McAdam, John D. McCarthy, and Mayer Zald, 1-22. New York, NY: Cambridge University Press. 
McCarthy, John, and Mayer Zald. 1977. "Resource Mobilization and Social Movements: A Partial Theory.” American Journal of Sociology 82, no. 6: 1212-41.

Mendez, Carlos. 2011. "The Lisbonization of EU Cohesion Policy: A Successful Case of Experimentalist Governance?" European Planning Studies 19, no. 3: 519-37.

Olsson, Lars-Erik, Marie Nordfeldt, Ola Larsson, and Jeremy Kendall. 2009. "The Third Sector and the Policy Process in Sweden-Path Dependence and Opportunity Structures." In Handbook of Third Sector Policy in Europe, edited by Jeremy Kendall, 159-183. Cheltenham, UK: Edward Elgar.

Salamon, M. Lester, Wojciech Sokolowski, and Regina List. 2004. "Global Civil Society: An Overview." In Global Civil Society: Dimensions of the Nonprofit Sector, edited by Lester M. Salamon, 3-60. Bloomfield, CT: Kumarian.

Sánchez-Salgado, Rosa. 2007. "Giving a European Dimension to Civil Society Organizations." Journal of Civil Society 3, no. 3: 253-69.

- 2010. "NGO Structural Adaptation to Funding Requirements and Prospects for Democracy: The Case of the European Union." Global Society 24, no. 4: 507-527.

—. 2013. "From 'Talking the Talk' to 'Walking the Walk': Implementing the EU Guidelines on Employment through the European Social Fund." European Integration Online Papers 17, no. 2: 1-26.

—. 2014a. Europeanizing Civil Society: How the EU Shapes Civil Society Organizations. Basingstoke, UK: Palgrave Macmillan.

—. 2014b. "Rebalancing EU Interest Representation? Associative Democracy and EU Funding of Civil Society Organizations." Journal of Common Market Studies 52, no. 2: $337-53$.

Scaramuzzino, Roberto. 2012. "Equal Opportunities? A Cross-national Comparison of Immigrant Organisations in Sweden and Italy." PhD diss. Malmö, Sweden: Malmö University.

Scaramuzzino, Roberto, Cecilia Heule, Håkan Johansson, and Aanna Meeuwisse. 2010. EU och den ideella sektorn-En studie av det svenska Equalprogrammet. FoU Rapport 2010-2. Malmö, Sweden: Malmö University.

Verschraegen, Gert, Bart Vanherck, and Rika Verpoorten. 201 1. "The European Social Fund and domestic activation policies: Europeanization mechanisms." Journal of European Social Policy 21, no. 1: 55-72.

Weishaupt, J. Timo. 2009. "Money, Votes or 'Good' Ideas? Partisan Politics and the Effectiveness of the European Employment Strategy in Austria and Ireland." In What We Have Learnt: Advances, Pitfalls and Remaining Questions in OMC Research, edited by Sandra Kröger. European Integration Online Papers Special Issue. Retrieved 13 Janurary 2014, from http://eiop.or.at/eiop/texte/2009-014a.htm. 


\section{Chapter 7}

\section{From Popular MOVEMENTS TO SOCIAL BUSINESSES \\ SOCIAL ENTREPRENEURSHIP AS DISCURSIVE EUROPEANIZATION}

\section{Ulrika Levander}

In recent years the concept of social entrepreneurship has gained strong recognition globally and is often viewed as a new policy paradigm whereby welfare delivery transcends traditional boundaries between the market, the state, and the family (Defourny and Nyssens 2008; Nicholls 2010; Nyssens 2006; Santos 2012). Although the understanding of social entrepreneurship varies between different cultural and national contexts, it is frequently conceptualized as social innovation processes undertaken by social entrepreneurs, which can refer to a broad range of activities from voluntary activism to corporate social responsibility in the for-profit sector (Defourny and Nyssens 2008; Gawell 2014; Kerlin 2006; Nicholls 2010). Despite a lack of clarity surrounding the phenomenon and its definition (Defourny, Hulgård, and Pestoff 2014a; Gawell 2014), social entrepreneurship is generally seen as a homogenous entity based on the premise that the application of business logics to third-sector ${ }^{1}$ organizations will bring the benefits of the market to consumers of welfare services and thereby solve contemporary welfare challenges (Defourny and Nyssens 2010; Kerlin 2006; Nicholls 2010).

In this chapter the concepts of social economy and social enterprise, both of which originated and spread from vital vocabularies in European Union (EU) social policies, are examined as cases of discursive Europeanization in a Swedish setting. The interaction of EU discourse and Swedish domestic 
discourse on the topic of social business is analyzed. The analysis focuses on the preexisting frames at the national and EU levels that have been used to elaborate social enterprise as a potential new and legitimate performer on the Swedish welfare landscape. In examining what kinds of resonances various discourses on the social economy sector have created, and how they have changed over time, I discuss and analyze the implications of social businesses as cases of discursive Europeanization in a Swedish setting in a wider institutional context.

\section{An Emerging Social Entrepreneurship Paradigm}

The increased interest of civil society actors as entrepreneurial welfare providers-or an emerging social entrepreneurship paradigm-is today emphasized in the policy arena of the European Union (EU), and in this context it is often talked of in terms of the social economy sector (see, e.g., EESC 2012). The term "social economy" was officially adopted in EU policies in 1989. As a concept, however, the term has a long history emphasizing social relations in human economies (Laville 2014; Polyani 1977; Trägårdh 2000). However, as a particular sphere of economic activity arising in civil society, the concept has gained increased recognition in the political discourse of recent years (Amin, Cameron, and Hudson 2002), and this is how it will be addressed in this chapter. Defourny and Develtere (2009) note that the concept of social economy, unlike the term "nonprofit," highlights the democratic processes in civil society organizations (CSOs) while allowing for profit distribution to the members of associations. They further argue that these specific characteristics have helped the notion of social economy to gain increased recognition from national and supranational authorities such as the EU.

Over the past few years the social economy sector has enjoyed increased political and legal recognition through the promotion of EU initiatives such as the Social Business Initiative, the European Foundation Statute, and the Social Entrepreneurship Funds. Whether the rising social entrepreneurship paradigm will lead to a greater opportunity for civil society and social economy actors to provide a more participative and pluralistic welfare, or instead result in unregulated welfare privatization, is today a highly contested subject (see e.g., cf. Anheier 2005; Clark and Johansson 2017; Defouny, Hulgård, and Pestoff 2014b; Laville 2014; Levitt 2013; Pestoff 2009). In similar discussions, the notions of new public governance (Osborne 2009) or coproduction (Pestoff 2012)-implying a provision of welfare services based on public-private networks-are often used to emphasize the necessity of state intervention and regulation in social 
entrepreneurship initiatives (Defourny, Hulgård, and Pestoff 2014a; Pestoff 2012).

\section{Social Entrepreneurship and the Swedish Welfare State}

Viewed in terms of Europeanization, emerging EU policies on social entrepreneurship might offer new political opportunities for CSOs to act on in domestic settings (Marks and McAdam 1996; Olsson et al. 2009). In Sweden, however, the idea of social entrepreneurship challenges institutionalized ways of understanding civil society because the sector's democratic functionas opposed to its economic or entrepreneurial facets-has traditionally been in focus. In the dominating Swedish discourse on civil society, the notion of popular movements has been used to describe the sector. In contrast to the European emphasis on service production and employment, issues of membership and representativeness are usually emphasized in the Swedish context (Hvenmark and Wijkström 2004; Olsson et al. 2009; Wijkström and Zimmer 2011). Thus clashes between the ideological and normative base of the EU project and the Swedish welfare state might challenge or pose a threat to the Swedish model and its view of the ideal relationships among the state, the individual, and civil society (Trägårdh 2007). Because welfare delivery has traditionally been framed as a public responsibility within the Nordic welfare system, space for service-producing CSOs has usually been limited (Esping-Andersen 1990; Salamon and Anheier 1998). However, as the Swedish welfare state underwent changes during the 1990s toward marketization and privatizations, a parallel shift from voice to service is today reflected in official civil society policies in Sweden (Lundström and Svedberg 1998; Lundström and Wijkström 2012). For example, in 2010 civil society was referred to for the first time in a Swedish government bill as "entrepreneurial" (Swedish Governement 2009). The very same year the Ministry of Enterprise (Swedish Government 2010) launched the Action Plan on Work Integration Social Enterprise. Similar actions illustrate how Swedish civil society today is increasingly framed in entrepreneurial terms in official policies, similar to the policies emerging at the European level. However, it must be emphasized that no official or general definition of the concepts of social entrepreneurship or social enterprise exist in Sweden today.

\section{Analytical Framework and Empirical Data}

Jacobsson (2004) speaks of the common use of language, vocabulary, and cognitive frameworks in the EU as Euro-discourse, serving the purpose of 
generating shared problem definitions in order to more easily frame common policy prescriptions and interventions within the EU. As described in chapter 1 which elaborates on the joint theoretical framework of this anthology, in processes of Europeanization civil society actors can be viewed both as active agents and as objects of structural constraints. Because ideas and projects initiated at the European level often leave a space for negotiation, civil society actors can actively take part in the creation, negotiation, editing, and translation of discourse into national settings (Mörth 2003). In this context, the concept of norm entrepreneur is relevant because it highlights the agency not only to translate, but also to diffuse and mobilize support for certain beliefs-for example as social entrepreneurship-in a national context (DiMaggio and Powell 1991; Börzel and Risse 2003). In processes of Europeanization, social entrepreneurs can simultaneously be understood as constrained by and/or as reproducing certain predominant domestically constructed narratives of civil society (Potter and Wetherell 1987). In this sense they are analytically understood as agents constrained by structural limits (Mörth 2003).

Central to the social constructivist approach adopted in this chapter, the analysis of social businesses discourse deconstructs how frames and demarcations change within-and between-different contexts and arenas where social businesses are described, at a policy level and among civil society actors. The analytical framework used brings attention to rhetorical variations that occur in discourse of social business, and what kinds of discursive negotiations and/or struggles this reveals (Laclau and Mouffe 2001). In the analysis the notion of frames of interpretation is used to describe smaller or locally constructed narratives of social business reflected in the talk conducted by civil society actors, while the concept of discourse signals inflections with wider institutional implications (Potter and Wetherell 1987). How different entities are categorized in diverse contexts by different actors, how varying practices of categorization influence the understanding of specific objects, as for example the social enterprise, and what kind of account practices are used to construct certain objects as trustworthy are of further analytical interest (Lakoff 1987; Potter 1996).

There are three main sources of empirical material used within this study. First, text documents from the Swedish state policy arena, where the phenomena of social enterprises and social economy are discussed. The policy texts consist of commission reports, government bills, and other Swedish government publications published between 1998 and 2014. Second, retrospective interviews with twelve Swedish key agents on social entrepreneurship that influence domestic policies for social enterprises. Third, texts consisting of debate articles and referral responses to political proposals to social enterprise matters published by Swedish Civil Society 
Organizations (CSOs) are used. The retrospective interviews were conducted with key agents who took on the role of consultation at the domestic level. These agents represent organizations such as the Swedish Association of Local Authorities and Regions, Coompanion, and the former Cooperative Institute. Retrospective interviews were also conducted with key agents from CSOs who run well-established social enterprises or umbrella organizations of social enterprises in Sweden, including the organizations Basta, Famna (The Swedish Association for Non-Profit Health and Social Service Providers), and Skoopi. Key agents who represent state-organizations involved in supporting and impacting social enterprises and national policies on social entrepreneurship, such as the Swedish Agency for Economic and Regional Growth, and the Swedish Public Employment Service, were also interviewed. All interviews were conducted during 2013 and 2014. The analytical emphasis of the chapter focuses on the public documents. Because the interviews mainly had a retrospective perspective, the central frames of interpretations and narratives appearing in the interviews are summarized rather than subjected to a transparent text analysis.

\section{The Talk of Social Business in the EU}

The embracing of the concept of social economy within the EU can be seen as a starting point of an emerging European social entrepreneurship policy paradigm, which became official in 1989 when the European Commission (EC) adopted a Communication on Business in the Social Economy Sector (EC 1989). As implementation of the economic and monetary union during the 1990s increased the economic interdependence among the EU member states, labor market and social policies gradually came to be defined as areas of common concern. In this transition the broad participation of civil society actors was encouraged (see, e.g., Hodson and Maher 2001; Jacobsson 2004). During the 1990s a specific political interest in finding new solutions to employment issues also emerged within the EU, which for example was reflected in the white paper "Growth, Competitiveness, Employment" (CEC 1993). This emerging interest in employment issues outlines the start not only of a shared European employment policy but also the framing of a common European employment discourse, where the notion of social economy came to be positioned as central in the emerging discourse (Sciarra 2000; Jacobsson 2004). The focus on an inclusive labor market, reflected in the adoption of the European Employment Strategy (EES) in 1997, stressing the need to increase the involvement of vulnerable groups in the labor market, further exemplifies how social economy actors were-and still today very much areregarded as vital agents in European efforts for social cohesion. 
As previously mentioned, the social economy sector has been subjected to increased political and legal attention within the EU. When the EC in 2011 launched the Social Business Initiative (EC 2011) in order to support the development of social enterprises, yet another step in demarcating a social entrepreneurship policy paradigm was taken. However, previous attention to the concept of social enterprise-as a specific entrepreneurial part of the social economy-was already paid, among others, by the European Research Network of Social Enterprises, whose EU-wide studies on the phenomenon in the early 2000s (Nyssens 2006; Defourny and Nyssens 2008) were financed by EU research funds. Yet through the Social Business Initiative the term "social enterprise" made a definite entrance into EU policies and has-as shall be seen in the analysis in this chapter-proven to be important for the framing-or reframing-of the discourse of social enterprise as it has emerged in Swedish policies.

\section{EU Policies on Social Enterprises-and Swedish Translations}

Looking into the policy arena of the EU, I identify several variations in the framing of social enterprises. In the Social Business Initiative, the EC (2011:682, p. 6) recognizes a range of definitions used across Europe and states that social entrepreneurship-when defined-does not necessarily have to mean exactly the same thing from one country to another. The EC $(2011: 682,4)$ further states that it itself "does not seek to provide a standard definition which would apply to everyone and lead to a regulatory straitjacket." However, in the Social Business Initiative the term "social enterprise" is used to cover the following types of business (EC 2011, 2-3):

- those for which social or societal objective of the common good is the reason for the commercial activity, often in the form of a high level of social innovation

- those where profits are mainly reinvested with a view to achieving this social objective

- and where the method of organization or ownership system reflects their mission, using democratic or participatory principles or focusing on social justice

Thus,

- businesses providing social services and/or goods and services to vulnerable persons 
- businesses with a method of production of goods and services with a social objective but whose activity might be outside the realm of the provision of social goods or services

As a part of the Social Business Initiative, a study to map the boundaries of social enterprise activities in the member states was initiated in 2013 (EU 2014). A growing interest and convergence in views across Europe regarding the defining characteristics of a social enterprise was found in the study, and Sweden was portrayed as one of the European countries in which a broad variety of support schemes specifically designed for social enterprises had been initiated. However, important variations in the use of social enterprise were identified within the member states. One of the issues was regarding the Swedish definition and understanding of social enterprise (EU 2014, 3): "In a few countries (Finland, Lithuania, Poland, Slovakia, and Sweden), the notion of social enterprise as articulated in national laws and/or policy documents narrowly focuses on work integration social enterprises (WISEs). This restricted definition excludes enterprises pursuing societal missions such as provision of social and educational services, the environment, well-being for all, or solidarity with developing countries."

Thus, the Swedish conception of social enterprise, although supported by national regulations (cf. Swedish Government 2010), appears to be narrower in scope than in most other European countries in only comprising the concept of work integration social enterprises, while in several other countries social enterprises are recognized as aiming at a much broader social economy. However, according both to the mapping report (EC 2014) and to Defourny and Nyssens (2010), work-integration social enterprises, delivering work-integrative activities to disadvantaged groups, is the most common form of social enterprises in Europe. Accordingly, work-integration social enterprises are framed in EU-related documents as the narrowest organizational form of social entrepreneurship and as only encompassing work-integration activities, while social enterprises in general are understood as organizations comprising a wider scope of social activities and ambitions, such as long-term care for the elderly and persons with disabilities, early education and child care, social housing, and so on.

\section{The Swedish Editing of the Social Economy}

Both in the Social Business Initiative (EC 2011) and the EU report mapping European social enterprises (EC 2014), the term "social economy" is spoken of in a taken-for-granted manner, which implies that the concept of social economy is regarded as clear and convergent in the EU policy arena. 
In Swedish state policy documents, however, this is not the case. In several public reports published in recent years, where central issues concerning social enterprises are discussed, the term "social economy" is not even mentioned (i.e., Ministry of Health and Social Affairs 2014; Swedish Government 2014a; Swedish National Board of Health and Welfare 2002, 2004). When the concept does appear, it is always followed by a definition or explanation (Swedish Government 2007b, 2009, 2013; Överenskommelsen 2009), such as the following example (Swedish Government 2009, 29, authors' translation): "The term social economy usually refers to organized economic activities which primarily have social purposes, are based on democratic values, and are organizationally independent of the public sector. Such activities are conducted primarily in associations, mutuals, non-profit associations, foundations, or cooperatives. The activities are of general utility or benefit for their members, and their primary purpose is not to obtain a return on capital." In either leaving out or-when mentioned-always adding a description, the concept of social economy emerges as less taken for granted in Swedish policies than in EU policy documents, where it is referred to as traditional. Although the Swedish government in 1998, three years after Sweden joined the EU, adopted an official definition of social economy (Swedish Government 1998), the use of the term has proved somewhat difficult. For instance, a predilection for categorizing the social economy as synonymous with popular movements is visible in official policies,such as in the Swedish Government Official Reports series paper "Movements in Our Time" (Swedish Government 2007b). Here, the term "social economy" is repeatedly used in tandem with the concept of popular movements. Because popular movements generally have connotations with democratic gains and being the voice of civil society, rather than providing a service delivery function (Hvenmark and Wijkström 2004; Wijkström and Zimmer 2011), to categorize social economy as a part of-or something synonymous withpopular movements risks obscuring the role of economic activities in social economy initiatives.

However, increased political interest in the participation of third-sector actors in welfare provision has been reflected in Swedish policies in recent years (see, e.g., Swedish Government 2009, 2014b). The process of generating a dialogue between the state and the Swedish voluntary sector, a dialogue that was initiated in 2007 and reached a formal agreement in 2008 (Överenskommelsen 2009), illustrates how actors of the third sector-mainly referred to as civil society organizations in today's Swedish policy discourse-are framed as important welfare agents, both in their role as welfare producers and as democratic multipliers. The government bill on "A Policy for the Civil Society," adopted in 2010, further underlines this political ambition (Swedish Government 2009). Here, for the first time in a 
formal policy context, social economy is talked of as "the entrepreneurship of civil society." This way of describing the social economy reflects two discursive shifts in regard to the prior Swedish talk outlined above. First, the official naming of the third sector has changed from popular movements to civil society, which mirrors an ongoing political negotiation taking place in recent years regarding the role of this sector in the Swedish welfare state-a debate where the sector's role as a provider or subcontractor of welfare goods is emphasized. Second, the social economy is no longer categorized as something synonymous-or in tandem-with popular movements in general. Rather, it is framed as a particular and entrepreneurial part of them, and the specific entrepreneurial feature of the social economy is thus emphasized. Along with this categorization, an accumulation of terms used in describing similar initiatives has now emerged, including the terms "societal entrepreneurship," "value-based enterprising," "associational entrepreneurship," "social enterprises," and so on (cf. Swedish Government 2009). Consequently, the talk of entrepreneurship of civil society seems on the one hand to reflect recognition of the Swedish civil society as entrepreneurial. On the other hand, the term "social economy" emerges as somehow displaced by other concepts, which implies a difficulty for the notion of social economy in gaining discursive ground in Swedish policies.

Considering the discourse of social economy and social enterprise sketched at the EU level, and the differing features indicated regarding the Swedish framing of these concepts, two main characteristics appear. First, the Swedish understanding of social enterprise differs from the mainstream European one, because work-integration social enterprises mainly stand out as the recognized form of such businesses in Swedish policies. Second, although recognized, the notion of social economy has not really been able to gain a definite foothold in Sweden. Instead, it appears to be overridden by other, and apparently more easily adopted, concepts.

\section{The Talk among Civil Society Actors}

Despite the lack of success in becoming a taken-for-granted concept in the Swedish policy arena, the notion of social economy is often mentioned in the interviews conducted with Swedish key agents on social enterprise. In the interviews the concept of social economy is often used in contexts where the EU's structural funds are mentioned, and thus Sweden's entrance to the EU: "Perhaps the most important thing I did was that I, in cooperation with others, got the concept of social economy to be included in the first Structural Fund programs when Sweden joined the EU... . I was involved in all three investigations reviewing how the Structural Funds were to be 
used . . . and they did not know what the social economy was." In this quotation, the interviewee positions themself not only as an active agent, but also as a norm entrepreneur in the process of recognizing and adopting the concept of social economy in the Swedish setting. Thus, not just the entrance to the EU, but also the Swedish European Social Fund (ESF) Council, a government agency under the Ministry of Labour responsible for managing the Social Funds in Sweden, are here categorized as central to creating new possibilities and openings for social economy actors in Sweden.

Similar frames of interpretation are narrated in other interviews. At stake in these narratives is the process of framing a new set of actors-the social economy-as legitimate in Swedish welfare policy accounts. The account practices used to construct social economy actors as trustworthy agents are partly elaborated toward the Euro-discourse at use in ESF contexts, where the notion of social economy is positioned as central. At least to some extent the regional partnerships established within the Swedish ESF Council, where the social economy is recognized and included as a partner, are used to articulate the importance of the social economy sector in gaining a formal say in a domestic context. Hence, both of these aspects are recurrently framed by the key agents as important in reshaping civil society's possibilities to affect national policies concerning the ESF (cf. Jacobsson 2004; Karlberg and Jacobsson 2015).

At this juncture, through statements referring to processes taking place in the late 1990s or early 2000s, key agents representing the sphere of work-integration social enterprises as well as other civil society initiatives are elaborating on narratives on the social economy. Thus, a wide framing of the social economy in terms of the overall civil society is visible in these narratives, which reflects the initial Swedish policy discourse of the social economy as more or less synonymous with popular movements in general.

\section{A Narrower Framing}

Looking into the talk conducted-both in interviews and in public documents-it is obvious that the use of the term "social economy" has declined over time in narratives delineating a wider understanding of social entrepreneurship. However, the concept is simultaneously situated as vital to the discourse of social enterprise emerging in Sweden. This is evident in the interviews conducted with the key agents representing the sphere of work-integration social enterprises. These agents depart from a talk of the social economy as the base point for their work.

In addition to the EQUAL Community Initiative, which was funded by ESF in the early 2000s and targeted labor market exclusion, Swedish 
national labor market policies directed to disadvantaged individuals emerge as a dominant financial support structure for the growth and creation of work-integration social enterprises in Sweden. As a turning point for the general recognition of the term "social enterprise" in Sweden, the formation of the National Thematic Group on Social Entrepreneurship (NTG socialt företagande) is pinpointed as central in several interviews. This was an initiative put together by the Swedish ESF Council and financed by funds from the Swedish EQUAL program between 2005 and 2007 in an attempt to have an impact on Swedish policies on social enterprises. In initiating, selecting, and inviting suitable projects representing social enterprises to make a joint National Thematic Group on Social Entrepreneurship, the ESF Council is in several interviews positioned as a central and powerful agent for deciding how the discourse on social enterprise is framed in Sweden. For instance, an interviewee described the work conducted and the aim of the national thematic group as follows:

What I believe is one of the most important activities, after all, is the National Thematic Group "NTG social entrepreneurship" in EQUAL. It was there that social enterprise became synonymous with work-integration social enterprises, and that was when the social enterprises came to include only the social work cooperatives, really. In order to be able to come forward at all politically on this, the politically smart ones among us understood that you had to limit the concept in order for the government to make an action plan on social enterprises. Because that was the goal of our work, it was to provide a basis for the government's action plan on social enterprises. And from a political perspective, rather than adopting the whole spectrum of social enterprises, the emphasis must be on the labor market and economic policies, and just these issues. It became quite technical.

In this narrative, the political space available for social enterprises is identified as the work-integration space. On the one hand, in managing to edit a discourse on social enterprise that has been adopted by the Ministry of Enterprise in the effort to support the development of workintegration social enterprises in Sweden, the National Thematic Group on Social Entrepreneurship here stands out as an active norm entrepreneur. On the other hand, the frames used in translating social enterprise into a Swedish setting are evidently limited by national labor market regulations and by the guidelines of the ESF. About 80 percent of all Swedish workintegration social enterprises are today receiving support from the National Employment Agency. The most common form of support is wage subsidies (lönebidrag), which are intended to offset an individual's impaired capacity to work (Tillväxtanalys 2011). Because work-integration social enterprises are mainly using already existing subsidies that are available in Swedish labor market policies, rather than seeking to have an impact on civil society policies 
in general, the National Thematic Group on Social Entrepreneurship is in this respect also to be understood as an agent under structural constraints (Mörth 2003).

\section{Social Businesses as Added Value}

Through the reinforcement of the European social entrepreneurship policy paradigm-reflected in the adoption of the Social Business Initiative in 2011-new framings of social enterprise appeared in Sweden. As a vital part of the Social Business Initiative, the need to change national procurement policies in order to take sufficient account of the specific characteristics of social enterprises was stressed. This was also echoed in Swedish policies. For example, the Swedish Government Official Report "Favourable Deals-a strategy for sustainable public procurement" (Swedish Government 2013) delineates public procurement as central to the possibility to make more political space available for Swedish CSOs acting as welfare deliverers. In the same report, a new way of framing social enterprise in a Swedish policy context appears. Rather than referring to the narrower understanding of work-integration social enterprises, the wider European understanding of social enterprise is now used. Hence, while the notion of social business is introduced in the Euro-discourse on social entrepreneurship, an understanding of social enterprises in its wider European sense is making an entrance in the Swedish policy room. Rather than the ESF and its focus on labor market inclusion, the Social Business Initiative (EC 2011)-and its focus on EU directives on procurement (The European Parliament and the Council of the European Union 2014)-is now used to negotiate the ongoing Swedish policy discourse of civil society in entrepreneurial terms.

\section{Diversity and Added Value}

In the process of increasingly framing civil society as an entrepreneurial force in welfare dealings, the term "value-based" entered into discourse. This is reflected, for instance, in the government publication "Roadmap to Public Procurement" (Swedish Governement 2014c, 15): "Value-based organizations"-social enterprises, cooperatives, associations, foundations, and non-profit organizations-represent an important resource in the community in actively contributing to diversity. Above all, they contribute to the development of quality in welfare service and the adaptation to users' needs and preferences. Moreover, several of these organizations contribute with an important voice for community groups that otherwise might 
find it difficult to be heard." Here, the concept of value-based emerges as an overall collective term for entrepreneurial civil society actors, in a similar way as the notion of social economy in the discourse framed at the EU level. Furthermore, social enterprises now seem to be understood as a wider phenomenon than just work-integration initiatives. In drawing on a discourse of diversity and added value in regard to civil society, a tendency to conceptualize this sector as unique and indispensible in welfare accounts is reflected, and the sector's double role of voice and service is emphasized. In similar framings of civil society, the increased numbers of private providers of welfare services are generally outlined as something positive. In contemporary Swedish policy contexts, a plurality of providers is hence assumed to enhance both quality and efficiency in welfare delivery.

\section{Business as Usual}

In the process of increasingly framing civil society as entrepreneurial, the sector is continuously subjected to dichotomizations when portrayed in official policies (cf. Lakoff 1987). For example, both in European and Swedish policy documents social enterprises-now understood in a wider sense-are often categorized in tandem with the private sector and forprofit businesses. This is reflected in the publication "Roadmap to Public Procurement" published in 2014 by the Swedish Ministry of Health and Social Affairs (Swedish Government 2014c, 3): "Private companies and non-profit organizations contribute with new solutions that improve the public sector's ability to meet society's various challenges." Here, the business and civil society spheres are described as one and as a similar force in the sense of acting as contributors to a plurality of welfare solutions. In this way, the added value of civil society is not specifically articulated. Rather, it is the nonpublic facet of private welfare providers that is in focus. CSOs are thus implicitly talked of and categorized like any other business.

Furthermore, a distinction between public and private is often made, such as in the government directives of an investigation on ownership assignments regarding what kinds of demands are feasible to put on private welfare providers (Swedish Government 2012, 2): "The lack of quality in elderly care, both publicly and privately operated, has been discussed." Here the dichotomization of public versus private is explicitly delineated, implying civil society actors as either nonexisting or as being a part of the private sector. The framing of civil society actors in business terms is also found in texts published by Swedish CSOs, such as in a review on the national implementation of the new EU directives on public procurement, published by Famna, a national federation of CSOs delivering health and welfare services: 
"Value-based [nonprofit] organizations share the positive effects of several of the directive's proposals with many small and medium-sized enterprises" (Famna 2013, 3).

The overall tendency to categorize welfare providers either as public or private, and to categorize nonpublic service providers as businesses, thus frames a dichotomization where the nonprofit angle tends to be left out; organizations delivering welfare services are either talked of as businesses or as part of the public sector. Thus many CSOs express concerns in taking part in procurements because the stipulated requirements usually do not match the added value of the services they perform (Famna 2013, 2): "Basically, value-based organizations are non-commercial actors who need to fit into a commercial system. It is urgent to find solutions in order for value-based organizations to be present and competitive without hampering their added value and capacity for innovation. In order for value-based health and welfare care to grow, legislation that is open to more flexible solutions than at present is required." The specificity of CSOs operating as a business is underlined here, drawing on the discourse of diversity and added value, which is also delineated in Swedish civil society policies. A somewhat contradictory identity emerges in the talk of civil society actors as noncommercial entities that are still categorized in traditional commercial terms as aiming to be competitive and to be part of a sector focused on growth.

Because EU directives on public procurement and the talk of social enterprises are framed as central in emerging discourses on welfare solutions, the national federation forum (The National Forum for Voluntary Organizations), which organizes voluntary nonprofit organizations, also emphasizes the risk of being overlooked as civil society agents (Forum 2014a):

When Forum developed the concept of "value-based public partnership" five years ago, it was precisely this question of identity that we had in mind. The kinds of activities we pursue are not suitable to be procured in a commercial-based market. The cheapest first [principle by which the cheapest provider of service gets the contract] does not apply to organizations whose main objectives are the very idea of social change... Value-based public partnership is thus not only an important method for public authorities to take the responsibility that we demand from them, but also for the non-profit competence to be taken seriously.

Here, it is the civil society identity that is positioned as threatened by the emerging social entrepreneurship paradigm. In referring to the importance that "public authorities take the responsibility that we demand from them," ideas in line with governance modes as emphasized by concepts such as new public governance (Osborne 2009) or coproduction (Pestoff 2012) are used as accounts to counteract the pitfalls of commercial-based markets 
where the cheapest first applies, and which is positioned as threatening to CSOs and their competence. Yet, in another publication reviewing an EU-initiated conference on social enterprise held in Strasbourg in 2014, representatives of Forum expressed the narrow Swedish interpretation of social enterprise as unfortunate (Forum 2014b):

The Swedish interpretation of social enterprise only enables public action, assistance, and funding to focus on the work-integration part of social entrepreneurship. The other parts are invisible to the Swedish public. This limited interpretation was also reflected in the Swedish participants attending this conference. Some actors from social enterprises and some people from organizations supporting WISEs were present. Hence, the Swedish public was quite invisible.... Because the political leadership of Europe now says that this is the sector that they want to invest in, building a future Europe, I believe that the limited Swedish public interest is troublesome. And boring!

On the one hand, the emerging social entrepreneurship paradigm is positioned in the illustrated examples as threatening to make the civil society aspect of nonprofits' work invisible. On the other hand, the narrow focus of social enterprises in Swedish policies is emphasized as making the dealings of social entrepreneurial initiatives invisible. Hence, a somewhat contradictory approach to the notion of social enterprise and social entrepreneurship currently appears among Swedish civil society actors, both wanting to be-and to be identified as-social businesses, and first and foremost not wanting to be made invisible in their identity as civil society agents. From a policy perspective, a similar paradox occurs in contemporary framings of social enterprise. On the one hand, civil society is increasingly categorized as entrepreneurial and as indispensable in welfare accounts. On the other hand, civil society's added value tends to be made invisible since it is subjected to a discourse of the for-profit sphere when talked of as social businesses.

\section{Conclusions}

Clear influences of Euro-discourse can be traced in the Swedish comprehension and use of social business-related terms because neither the concept of social economy nor the term "social enterprise" were really in use in Sweden before the country entered the EU (cf. Jacobsson 2004). Simultaneously, a taken-for-granted European understanding of these terms has not readily occurred in Sweden. Rather, a path dependency on historical ways of understanding both the domestic civil society sector and the traditional welfare state is seen in the discursive negotiations taking place (cf. Trägårdh 2007). 
As cases of discursive Europeanization, the concepts of social economy and social enterprise also take different, but still kindred, routes into Swedish policy settings. In both cases, actors of Swedish civil society can be identified as active norm entrepreneurs in editing and adopting the terms into Swedish policies. When the Swedish government adopted an official definition of the concept of social economy (Swedish Government 1998), this process was clearly narrated as having been accomplished through the active involvement of the interviewed key agents. Likewise, the Action Plan on Work Integration Social Enterprises, adopted by the Ministry of Enterprise in 2010, was preceded by active lobbying by the National Thematic Group on Social Entrepreneurship, an initiative hosted by the Swedish ESF Council and financed with EQUAL funds.

However, the frames used in translating the term "social enterprise" into a Swedish setting were evidently accomplished by existing opportunities in national labor market regulations. In this respect, the public discourse that was framed was narrower in scope than in most other European countries, and the impact of a Euro-discourse is thus to be understood as under structural constraints by national policies and institutional understandings (Mörth 2003). The same goes for the term "social economy," where national institutional constraints have contributed to-in this case-a wider understanding of the concept compared to the understanding in most other European countries. In both cases the entrepreneurial and economic parts of the original concepts seem to be unrecognized in the Swedish translations. Analytically, this can be understood as the economic activities and grounds at this time-that is, the late 1990s and early 2000s, not really being part of the prevailing discourse on Swedish civil society. It was simply not a trustworthy way of speaking of this sector, and thus it could not be included in discourse.

In 2010 Swedish civil society was for the first time positioned, and recognized, as entrepreneurial in a government bill (Swedish Government 2009). In 2014 the concept of social enterprise was also delineated as having a possibly wider understanding than just work integration in Swedish public policies (Swedish Government 2013). Thus, when it comes to social entrepreneurship and the agency attributed to civil society actors, the discursive possibilities available in Sweden have changed over time. This also affects the view of civil society and the general positioning of CSO actors in Sweden. But again, the framings are constrained by institutional ideas of civil society-or maybe this time the business sphere. That is, in the transition toward increasingly framing civil society as entrepreneurial, an overall tendency to categorize welfare providers either as public or private is visualized in the discourse. Similar dichotomizations support an understanding of entrepreneurial CSOs as businesses first and foremost. Consequently, the importance of the added value of the sector tends to be downplayed. 
The concluding paradox of the Euro-discourse on social business framed in Sweden is consequently that although an emerging social entrepreneurship paradigm is visible in the political agenda, civil society is constantly made invisible through dichotomies in the talk of social entrepreneurs. Previously, the overall popular movement identity of Swedish civil society overshadowed its entrepreneurial or economic agency. Today the same sector tends to be overshadowed by logics adopted by for-profit businesses. In both cases, clear processes of discursive Europeanization are visualized, while structural and institutional features at the domestic level limit the possible understandings that are framed (cf. Marks and McAdam 1996; Olsson et al. 2009; Trägårdh 2007).

That boundaries between civil society initiatives and the market tend to be blurred in social entrepreneurship policies is also a matter vividly discussed in contemporary third-sector research. Generally, greater state responsibility in the policymaking of this area is requested (cf. Anheier 2005; Clark and Johansson 2017; Defouny, Hulgård, and Pestoff 2014b; Laville 2014; Levitt 2013). One way this has been discussed is in terms of new public governance, which implies various forms of coproductions between the private and the public sectors as a way to regulate the outcome in welfare terms (Osborne 2009; Pestoff 2009, 2012). But in order for coproduction to take place, a clear recognition of and interest in implementing real changes regarding the role of CSOs in welfare delivery is needed. Considering the Swedish discourses on social entrepreneurship analyzed in this chapter, where the positioning of the social entrepreneur-independently of which discourse we look at-is constantly put in the discursive shadow and thus is made invisible, such recognition has apparently not yet been attained.

Ulrika Levander is Senior Lecturer in Social Work at Lund University in Sweden, where she teaches and trains bachelor and master students at the School of Social Work. Her research focuses on social enterprises, how social entrepreneurship is expressed within the civil society, and how mental health issues among socially exposed groups of children and young people have been classified and understood, both historically and today.

\section{Notes}

1. Both in political and scientific contexts, various terminologies, such as the "third sector," the "voluntary sphere," and the "nonprofit sector" are today in use to describe civil society. In this chapter I will principally use the term "civil society" in referring to this sphere. However, because the concept of the third sector is often used in 
European research literature on the social economy and social enterprise, and in this context more or less is used synonymously with the concept of civil society, I will alternate my use of this terminology in order to vary the language.

2. The term "value-based public partnership" is today in use in Sweden to emphasize welfare delivery or services based on partnerships or networks between CSOs and the public sector.

\section{References}

Amin, Ash, Angus Cameron, and Ray Hudson. 2002. Placingthe Social Economy. London, UK: Routledge.

Anheier, Helmut. 2005. Nonprofit Organizations: Theory, Management, Policy. Abingdon, UK: Routledge.

Börzel, Tanja, and Thomas Risse. 2003. "Conceptualizing the Domestic Impact of Europe." In Featherstone and Radaelli, The Politics of Europeanization, 57-81.

CEC. 1993. "Growth, Competitiveness, Employment, the Challenges and Ways Forward into the 21 st Century," COM(93)700. Brussels, Belgium: Commission of the European Communities.

Clark, Eric, and Håkan Johansson. 2017. "Social Economy and Green Social Enterprises: Production for Sustainable Welfare?" In Sustainability and the Political Economy of Welfare, edited by Max Koch and Mont Oksana, 158-71. London, UK: Routledge.

Defourny Jacques, and Marthe Nyssens. 2008. "Social Enterprise in Europe: Recent Trends and Developments." Social Enterprise Journal 4, no. 3: 2002-228.

- 2010. "Conceptions of Social Enterprise and Social Entrepreneurship in Europe and the United States: Convergences and Divergences." Journal of Social Entrepreneurship 1 no. 1: 32-53.

Defourny Jacques, and Patrick Develtere. 2009. "The Social Economy: The Worldwide Making of a Third Sector." In The Worldwide Making of the Social Economy. Innovations and Changes, edited by J. Defourny, P. Develtere, B. Fonteneau, and M. Nyssens, 15-40. Leuven, Belgium: Acco.

Defourny Jacques, Lars Hulgård, and Victor Pestoff. 2014a. "Introduction to the 'SE field." In Defourny, Hulgård, and Pestoff, Social Enterprise and the Third Sector, $1-14$.

—, eds. 2014b. Social Enterprise and the Third Sector. Changing European Landscapes in a Comparative Perspective. London, UK: Routledge.

DiMaggio, Paul, and Walter Powell. 1991. "The Iron Cage Revisited: Institutional Isomorphism and Collective Rationality in Organisational Fields." In The New Institutionalism in Organisational Analysis, edited by W. Powell and P. DiMaggio, 41-62. Chicago, IL: University of Chicago Press.

EC. 1989. Communication on Business in Social Economy Sector. Brussels, Belgium: European Commission.

—. 2011. Social Business Initiative. COM (2011) 682. Brussels, Belgium: European Commission.

. 2014. A Map of Social Enterprises and their Eco-Systems in Europe: Synthesis Report. Brussels, Belgium: European Commission. 
EESC. 2012. The Social Economy in the European Union. Brussels: European Economic and Social Committee.

The European Parliament and the Council of the European Union. 2014. DIRECTIVE 2014/24/EU on public procurement and repealing of 26 February 2014. Official Journal of the European Union, 28 March 2014.

Esping-Andersen, Gösta 1990. The Three Worlds of Welfare Capitalism. Cambridge, UK: Polity.

Famna. 2013. EU:s nya upphandlingsdirektiv. Famnas bedömning av möjligheterna att, utifrån det nya EU-direktivet, utveckla upphandlingsregelverket med fokus på tillväxt av idéburen vård och omsorg. Stockholm, Sweden. Retrieved from http://media.famna2012. famna.org/2012/05/EUs-nya-upphandlingsdirektiv-Famnas-syn.pdf.

Featherstone, Kevin, and Claudio Radaelli, eds. 2003. The Politics of Europeanization. Oxford, UK: Oxford University Press.

Forum. 2014a. "Regeringen - följ Sigtuna och våga stötta IOP.” Retrieved 26 November 2014, from https://www.socialforum.se/article/vi-vill-uppmana-regeringen-att-fol ja-exemplet-i-sigtuna-vaga-stotta-ideburet-offentligt-partnerskap/.

— . 2014b. "Konferensen var en början på en ny process." Retrieved 20 November 2014, from http://www.socialforum.se/?article=konferensen-var-en-borjan-pa-enny-process.

Gawell, Malin. 2014. "Social Entrepreneurship and the Negotiation of Emerging Social Enterprise Markets.” International Journal of Public Sector Management 27, no. 3: 25l-66.

Hodson, Dermot, and Imelda Maher. 2001. "The Open Method as a New Mode of Governance: The Case of Soft Economic Policy Co-ordination." Journal of Common Market Studies 39, no. 4: 719-46.

Hvenmark, Johan, and Filip Wijkström. 2004. "The Popular Movement Marinade, the Dominant Civil Society Framework in Sweden." Working Paper Series in Business Administration, Stockholm, Sweden: School of Economics/EFI, Stockholm.

Jacobsson, Kerstin. 2004. "Soft Regulation and the Subtle Transformation of States: The Case of EU Employment Policy." Journal of European Social Policy 14, no. 4: 355-70.

Karlberg, Eva, and Kerstin Jacobsson 2015. "A meta-organizational perspective on the Europeanization of civil society: The case of the Swedish Women's Lobby." VOLUNTAS: International Journal of Voluntary and Nonprofit Organizations 26, no. 4: $1438-59$.

Kerlin, Janelle. 2006. "Social Enterprises in the Unites States and Europe: Understanding and learning from differences." VOLUNTAS: International Journal of Voluntary and Nonprofit Organizations 17, no. 3: 247-63.

Laclau, Ernesto, and Chantal Mouffe. 2001. Hegemony and Socialist Strategy: Towards a radical democratic politics, 2nd ed. London, UK: Verso.

Lakoff, George. 1987. Women, Fire and Dangerous Things. What Categories Reveal about the Mind. Chicago, IL: University of Chicago Press.

Laville, Jean-Louis. 2014. "The Social and Solidarity Economy: A Theoretical and Plural Framework.” In Defourny, Hulgård, and Pestoff, Social Enterprise and the Third Sector, $102-13$.

Levitt, Karl P. 2013. From the Great Transformation to the Great Financialization. London, UK: Zed Books.

Lundström, Tommy, and Lars Svedberg. 1998. "Svensk frivillighet i internationell belysning-en inledning." Socialvetensakaplig tidskrift 2, no. 3: 106-27. 
Lundström, Tommy, and Filip Wijkström. 2012. "Från röst till service: Vad hände sedan?." In Civilsamhället i samhällskontraktet, edited by F. Wijkström, 245-288. Stockholm, Sweden: European Civil Society Press.

Marks, Gary, and Doug McAdam. 1996. "Social Movements and the Changing Structure of Political Opportunity in the European Union." Journal of West European Politics 19: 249-78.

Mörth, Ulrika. 2003. "Europeanization as Interpretation, Translation, and Editing of Public Policies." In Featherstone and Radaelli, The Politics of Europeanization, 159-78.

Nicholls, Alex. 2010. "The Legitimacy of Social Entrepreneurship: Reflexive Isomorphism in a Pre-Paradigmatic Field." Entrepreneurship Theory and Practice 34, no. 4: $611-33$.

Nyssens, Marthe, ed. 2006. Social Enterprise-At the Crossroads of Market, Public Policies and Civil Society. London, UK: Routledge.

Olsson, Lars-Erik, Marie Nordfeldt, Ola Larsson, and Jeremy Kendall. 2009. "Sweden: When Strong Third Sector Historical Roots Meet EU Policy Processes." In Handbook on Third Sector Policy in Europe-Multi-Level Processes and Organized Civil Society, edited by Jeremy Kendall, 159-83. Cheltenham, UK: Edward Elgar.

Osborne, Stephen P. 2009. The New Public Governance? Emerging Perspectives on the Theory and Practice of Public Governance. London, UK: Routledge

Pestoff, Victor. 2009. A Democratic Architecture for the Welfare State. London: Routledge.

—. 2012. "Co-production and Third Sector Social Services in Europe: Some Concepts and Evidence." VOLUNTAS: International Journal of Voluntary and Nonprofit Organizations 23, no. 4: 1102-18.

Polyani, Karl. 1977. The Livelihood of Man, edited by H. Pearson. New York, NY: Academic Press.

Potter, Jonathan. 1996. Representing Reality. Discourse, Rhetoric and Social Construction. London, UK: SAGE.

Potter, Jonathan, and Margaret Wetherell. 1987. Discourse and Social Psychology. London, UK: SAGE.

Salamon, Lester, and Helmut Anheier. 1998. "Social Origins of Civil Society: Explaining the Nonprofit Sector Cross-nationally." VOLUNTAS: International Journal of Voluntary and Nonprofit Organizations 9, no. 3.

Santos, Filipe. 2012. "A Positive Theory of Social Entrepreneurship." Journal of Business Ethics 111, no. 3: 335-51.

Sciarra, Silvana. 2000. "Integration through Coordination: The Employment Title in the Amsterdam Treaty.” Columbia Journal of European Law 6, no. 2: 209-29.

Swedish Government. 1998. Social Ekonomi i EU-landet Sverige-tradition och förnyelse i samma begrepp. Ds 1998:48. Stockholm, Sweden: Government Offices of Sweden.

—. 2003. ArbetsKraft. Betänkande från Lönebidragsutredningen. Official Reports series. SOU 2003:95. Stockholm: Fritze.

- 2006. Ambition och ansvar. Nationell strategi för utvecklandet av samhällets insatser till personer med psykiska sjukdomar och funktionshinder. SOU 2006:100. Stockholm: Fritze.

. 2007a. Från socialbidrag till arbete. SOU 2007:2. Stockholm: Fritze. 2007b. Rörelser itiden. Stockholm: SOU 2007:66. Fritze.

- 2009. En politik för det civila samhället. Prop. 2009/10:55. Stockholm, Sweden:

Government Offices of Sweden. 
2010. Action Plan on Work Integration Social Enterprises. N2010/1894/ENT.

Stockholm, Sweden: Swedish Government.

—. 2012. Tilläggsdirektiv till Ägarprövningsutredningen (Fi 2012:11). Dir. 2012:131.

Stockholm, Sweden: Finansdepartementet, Government Offices of Sweden.

—_. 2013 Goda affärer-en strategi för hållbar offentlig upphandling. SOU 2013:12.

Stockholm: Fritze.

. 2014a. Nya regler om upphandling. SOU 2014:51. Stockholm, Sweden: Fritzes.

—. 2014b. Ett stärkt och självständigt civilsamhälle. Dir. 2014:40. Stockholm, Sweden:

Utbildningsdepartementet, Government Offices of Sweden.

—. 2014c. Färdplan för den offentliga upphandlingen. S2 104.022. Stockholm, Sweden:

Ministry of Health and Social Affairs, Government Offices of Sweden.

Swedish National Board of Health and Welfare. 2002. Vårdens värde. Vad fär vi för pengarna i vård och omsorg? Stockholm, Sweden: Socialstyrelsen.

- 2004. Staten, ideella organisationer eller du själv-vem står för välfärden i framtiden?

Socialstyrelsens årliga konferens om den ideella sektorn 2004. Stockholm, Sweden: Socialstyrelsen.

Tillväxtanalys. 2011 . Arbetsintegrerande sociala företag-användning och behov av statligt finansieringsstöd. Dnr. 2011/116. Östersund, Sweden: Myndigheten för tillväxtpolitiska utvärderingar och analyser.

Trägårdh, Lars. 2000. “Utopin om den sociala ekonomin.” In Kooperativ Arsbok 2000. Stockholm, Sweden: Kooperativa Förbundet.

—. 2007. "The 'Civil Society' Debate in Sweden: The Welfare State Challenged." In State and Civil Society in Northern Europe-The Swedish Model Reconsidered, edited by L. Trägårdh, 9-36. New York, NY: Berghahn Books.

Wijkström, Filip, and Annette Zimmer. 2011. Nordic Civil Society at a Cross-Roads. Transforming the Popular Movement Tradition. Baden-Baden, Germany: Nomos.

Överenskommelsen. 2009. Överenskommelsen mellan regering, idéburna organisationer inom det sociala området och Sveriges Kommuner och Landsting. IJ2008/2110/UF. Stockholm, Sweden: Government Offices of Sweden. 


\title{
Chapter 8
}

\section{VARYING DEgREeS OF EUROPEANIZATION IN SWEDISH WOMEN'S ORGANIZATIONS}

\author{
Ylva Stubbergaard
}

European Union (EU) institutions and EU policies have become of interest for an increasing number of civil society organizations (CSOs) in Sweden, but not for all. This study has the overall aim of understanding how and why different women's organizations ${ }^{1}$ are active at different levels of policymaking. Scholars have found several reasons for CSOs to aim for participating in policymaking at the EU level (della Porta and Caiani 2009; Sánchez-Salgado 2007, 2014; Strid 2009). In this study the alternative-to not actively try to participate at the EU level-is equally interesting to analyze.

The analysis is influenced by Nancy Fraser's ( 2008, 2005; Fraser and Nash 2014) work on reimagining political space. Fraser focuses on the principal question of justice in times when political levels are being transformed in terms of transnationalization and globalization. For this chapter, the approach has particularly contributed to the dimensions of participation at different policymaking levels.

The dimensions of analysis are adjusted to suit the main research question on why women's CSOs are active to a varying extent at different levels of policymaking. The following questions have guided the analysis: What issues within gender equality do the CSOs focus on? How are formal and informal processes of policymaking at the EU level perceived and used by the CSOs? Who is formally included in decision-making processes? And how are the CSOs reacting to the principles of inclusion at the EU level? 
The different reasons for organizations to Europeanize are expected to lead to different extents of Europeanization because different goals are connected to different regulations and resources and to different activities by the CSOs. With the interactive perspective on Europeanization that was outlined in chapter 1, CSOs are considered to be subjects in Europeanization processes when they participate with the aim to influence ideas, discourses, policies, or structures connected to the EU. They might also be constrained by different conditions set by political institutions, by their relations to other CSOs, or by issues on the political agenda. In this sense the CSOs can be discussed as objects in Europeanization processes.

Interviews with representatives of thirty-four Swedish women's organizations and analyzes of their websites during 2014-16 constitute the material for the study. ${ }^{2}$ The extent of their relations and activities at the EU level are categorized as three degrees of Europeanization-weak, medium, or strong. The analysis is based on information provided by the organizations regarding the dimensions of what, how, and who, and on how patterns of participation at different levels of policymaking covary with the extent of Europeanization.

This chapter is organized into three parts. The first section introduces the analytical dimensions of participation. The second part aims to contextualize the work of women's organizations, starting with a historical overview of the development of Swedish women's organizations that helps to explain relations between state institutions and CSOs. The second part also includes a section on institutional conditions in the EU that have an impact on opportunities for women's organizations to take part in gender policymaking. This part ends with an introduction to the Nordic Forum (Nordiskt Forum 2014), the venue at which interviewees for this study were identified. Finally, in the third part the results of the analysis of the interviews are presented and discussed as patterns of participation.

\section{Analytical Dimensions of Participation}

The theoretical point of departure is based on Fraser's metanorm on justice, formulated as "parity of participation." The norm refers to the possibility to participate in policymaking on equal terms. Fraser's way of discussing levels of representation and the questions of what matters contributes to studies of complex relations and activities connected to participation at different policymaking levels. Changed division of political and administrative space should, according to Fraser's norm of parity of participation and justice of frame-setting, be decided by those who are or will become subjects of the 
regulations. Transferred to the chapter's discussion of Europeanization of CSOs, the analytical model of parity of participation raises the following questions: What kinds of issues are matters for the CSOs? How are the associations acting to influence decision-making? Finally, who is counted as a subject with the right to make claims in the EU?

The question of "what" concerns three dimensions-redistribution, recognition, and representation. Redistribution is about transforming a gendered structure of economy and refers to claims for a just redistribution of resources and wealth. Women's organizations focusing on redistribution are often engaged in welfare issues and in advocacy for equal pay for men and women. Recognition refers to claims for equal status. In this chapter this denotes gender status order and claims for structures that promote equal respect for women (Fraser and Honneth 2003). ${ }^{3}$ Representation refers to equal political representation and is here focused on women's possibilities to have an equal impact on decision making. All three dimensions need to be considered according to the idea of parity of participation.

The question of "how" refers to procedures of decision making (Fraser 2008 , 29). Answering this question gives information about the kinds of activities the CSOs make use of, and are able to use, when they aim for participation and influence. Examples of processes that can be used by CSOs are hearings, consultations, and dialogues. It should be emphasized that it is how opportunities and obstacles are perceived by the CSOs that is analyzed here (Suh 2001; Eduards 2002). Research has emphasized funding as a mechanism that strengthens CSOs' possibilities to participate at the EU level (cf. chapter 6), including funding from the European Commission as well as from member states and international organizations like the OECD (Kohler-Koch and Finke 2007; Sánchez-Salgado 2014).

The question of "who" seeks to identify the subjects of Europeanization processes that have the possibility to claim influence and emphasizes the principles of inclusion (Fraser 2008; Fraser and Nash 2014). For the aim of this chapter, the "who" question informs whether perceived obstacles to inclusion can clarify why CSOs participate to various extents at the EU level. A question of relevance for the organizations is that of who is invited to participate in dialogues. The access to these processes is also decisive for the activities used by them.

Borders of a polity and the demarcation between members and nonmembers of a polity are especially problematic in a time when more and more issues are important at other levels than the national and need to be regulated at other levels as well. Sometimes CSOs can make use of multiple levels of decision making, for example when transnational and global arenas facilitate women's organizations' struggles for local recognition. When organizations participate in global campaigns on women's rights, the purpose 
is to transform international law, which in the next phase might affect the organizations' domestic situation (Yuval Davis 2010; Fraser 2008, 14).

Another aspect of participation, emphasized by Fraser, is about opportunities to have an impact on meta-discourses on how boundaries of the political space should be drawn. Who has the possibility to influence the political space? Fraser uses the concepts of affirmative politics and transformative politics to describe two different approaches to these discourses. With affirmative politics, the borders and decision-making levels are accepted. Transformative politics instead questions the appropriateness of the specific boundaries. This latter aspect of political space is used to draw attention to whether CSOs actively accept or resist the EU as a political and administrative level.

To summarize, the analysis focuses on how the three dimensions of what, how, and who are connected to the extent of Europeanization in terms of how the organizations are related to, and engage in activities with the EU, in terms either of its policies or its institutions.

\section{Swedish CSOs Working on Gender Equality in a Historical Perspective}

The development of the women's movement is often described in three waves that constitute stories of how the movement has focused on different issues, but also how it has changed in character. These changes are clearly connected to the development of social movements in general as described by several researchers (e.g., Buechler 1995; Eschle 2001; Fraser 2008).

The first wave is described as a broad popular movement from the middle of the nineteenth century when women began organizing for civil and political rights with the claim for universal suffrage as the main objective. There is a general story of the Swedish women's movement as relatively homogeneous, and it is described as mainly reformist and with collaborations with male-dominated institutions during this period. However, researchers have reread historical reports of the women's movement and concluded that previous research has tried to create a consistent and homogeneous image of the women's movement despite obvious conflicts between different women's organizations (Manns 2000; Rönnbäck 2000). Differences in the women's movement appeared already in the first wave, which was concurrent with the development of other Swedish CSOs. A decision on universal suffrage was made in Sweden in 1919, which was comparatively late, and in the 1921 election women voted for the first time.

The second wave, starting in the 1960s, is described as focused on questions of work, care, and women's control over their sexuality and 
reproduction. During this period women's organizations were accepted and integrated in the public sector and were invited to inform about their activities in schools and public institutions; parts of the movement developed into women's sections in party organizations (Schmitz 2007). In this second wave the women's movement was organized into flat organizations as reactions to traditional hierarchical organizations. This nonhierarchical organization created problems when, for example, women's shelters sought funding for their activities (ROKS, n.d.). To receive contributions, an organization was required to be internally democratic with a formally accountable board of directors. To receive municipal grants, the organization had to be free from sex discrimination-in other words, men had to be eligible to be members (Eduards 2002).

The third wave of the women's movement began in the 1990s and is described as a phase when internal conflicts and power relations within the movement can be recognized. Even the organizational forms changed during this time, and the movement developed into several different networks (Gustafsson, Eduards and Rönnblom 1997). This third wave has particularly criticized the earlier movements for defining sisterhood and women's interests as if they were universal to all women. Instead, it is important to recognize how multiple bases of power intersect in a context-specific way (Eschle 2001; Mohanti 2003; de los Reyes and Mulinari 2005; Stoltz 2000). Postcolonial feminist research also criticizes this division of the feminist movement into three different waves with the argument that it is the result of a Westernized perspective on the development of the women's movement (de los Reyes 2014).

Historically, CSOs in Sweden have had close relations to government authorities. The relations between CSOs and state institutions could be problematized because of the risk of co-optation, which is described and assessed in many ways, one of which is that the authorities set frames of what is possible to do in a way that causes the organisations to lose their critical potential toward government policies (Gamson 1968, 1990). Close connections between women's organizations and the Swedish state have resulted in an insider strategy by the CSOs (Bergqvist and Findlay 1999). One consequence of such a strategy is a weakened need to create autonomous and separate organizations (Briskin 1999, 12). An example of this insider strategy is women's sections within political parties, which were mainly created during the 1970s and 1980s. These party sections had regular contact with women's organizations, and the CSOs were invited to dialogues with government agencies. The Swedish state is moreover described as women-friendly because of the government's and parliament's willingness to initiate and implement welfare reforms that support women's positions. Since the 1970s, women's formal representation in the parliament and 
the government has increased and is now one of the strongest in the world (Sainsbury 2004; Bergqvist, Adman, and Jungar 2008).

However, whether CSOs organized outside the party system and state institutions can be judged as independent from political and administrative institutions is a question that has to be investigated empirically from a broader approach.

\section{Gender Equality at the EU Level}

The main research question in this study is why Swedish women's CSOs are active at different levels of policymaking, with an additional interest in why some CSOs are not trying to participate at the EU level at all. This section presents a brief overview of institutional conditions that promote CSOs' participation at the EU level within the area of gender equality (Stubbergaard 2015).

The EU specified a policy to strengthen its cooperation with CSOs in 2002 (EC 2002) This policy, together with the white paper on EU governance (EC 2001), has been interpreted as a desire to encourage CSOs to participate in the EU for two main reasons-first to increase the legitimacy of the EU, due to the democratic deficit, and second to get expert advice from the CSOs (Greenwood 2007). Sofia Strid (2009) describes how the European Women's Lobby (EWL) as an organization has developed in parallel with reforms within the EU and how institutions and reforms have functioned as political opportunity structures to extend women's influence on gender equality. Reforms have changed the competence of the EU political institutions, changed policymaking processes, and broadened the policy areas (Strid 2009, 130, EWL 2016). Three phases of formal reforms on gender equality have been distinguished. First were reforms that emphasized equal opportunities, especially on the labor market, second were reforms encouraging positive action, and third were reforms that promoted gender mainstreaming with the ambition of integrating gender equality in all policy areas (Mokre and Borchorst 2013). Another description of the EU focuses on the EC as a consultation regime and concludes that the development of the relations with CSOs can be differentiated in three types of formal generations-first the hierarchical relations during the 1960s-1970s, then partnerships during the 1980s-1990s, and finally participation toward full partnership as stated in the white paper on European governance (KohlerKoch and Finke 2007).

There are several political and administrative institutions in the EU that are working on gender issues, and various women's CSOs have different relations to these institutions. The EWL has a close relation to the Committee 
on Women's Rights and Gender Equality in the European Parliament (EP) (Stubbergaard 2015), among others. The EWL has become the main CSO in the policy field of gender equality. It was founded with support from the EC in 1990, and it receives the main part of its funding as a grant from the EC. It describes itself as a link between citizens and decision makers at the EU level; in addition to this political and administrative level of action it plays an advisory role in the UN. The EWL is an umbrella organization with more than two thousand member organizations; the thirty national coordinators are full members with the right to vote in the yearly assembly meetings. One of the reasons for the EC to support the EWL is its need of expert information and advice on gender equality issues because it is obliged to promote gender equality. To have a strong CSO as a partner in this policy area facilitates the policymaking processes (Strid 2009).

The EWL is also a member of the Social Platform (see chapter 2), which gives the umbrella organization a strong position in the EU network of CSOs (Cullen 2003, 2010; Johansson and Kalm 2015). The Swedish Women's Lobby (SWL) is the national coordinator in Sweden of the EWL (Strid 2009; Stubbergaard 2015; SWL 2015); it was established in 1997 as an umbrella organization and consists of more than forty member-organizations today.

\section{Nordic Forum on Women's Rights}

A Nordic conference on Women's Rights was held in 2014. The SWL took the first initiative to hold this conference in 2011 , and a committee made up of women's CSOs in the Nordic countries planned and arranged the conference. The conference constitutes the arena from which the interviewees for this study were recruited.

The Nordic Forum held in Malmö in June 2014 had the theme New Action on Women's Rights; it was a continuation of the Nordic conferences that were held in Oslo in 1988 and in Turku in 1994. One purpose of the Nordic Forum was to formulate a final document based on discussions from the conference and to continue the discussion of the Beijing Platform for Action on the Elimination of all forms of Discrimination against Women (CEDAW). The Nordic governments supported the forum and contributed financially.

CSOs, authorities, and politicians from the Nordic countries participated at the Forum together with guests from other regions in the world. The topic of the EU came up in the program only a few times. Nevertheless, it was presupposed for this study that CSOs that take an active part at the Nordic Forum are more prepared than others to participate in activities beyond national borders and are interested in making contacts with other CSOs. 
This made the Nordic Forum a good opportunity to get information on the extent of participation at different policy levels from a range of different women's organizations. However, the ambition of this study was not to assess the numbers of organizations with weak or strong Europeanization but was instead to find a pattern of correlation between the analytical dimensions of what, how, and who, and the organizations' extent of Europeanization.

The selection criteria for the interviews were that the organizations should participate in the Nordic Forum, have their main activities in Sweden, be a nonprofit organization, and represent nonstate actors.

The analysis is based on telephone interviews with representatives of thirty-four Swedish CSOs that participated in the Nordic Forum in very different ways. ${ }^{4}$ Some gave lectures on their key issues, while others organized workshops or took part in seminars. Some were well-established CSOs, and some had participated in the planning process of the Forum, while others were newly organized, and some felt marginalized in the network of women's organizations.

The interview questions were directed by the three comprehensive research questions based on the what, how, and who dimensions, and they were designed with the purpose of providing information on why the CSOs differ in their activities and commitment at different levels of policymaking.

\section{Participation at Different Political Levels among Swedish CSOs within Gender Issues}

In table 8.1, the responses by the CSOs are categorized as representing strong, medium, or weak Europeanization according to their activities and their relations with the EU. The extent of Europeanization is linked to what kind of goals, activities, and policy levels of participation that characterize the organizations. The table is a compilation of the analyses of thirty-four interviews with CSOs representatives. An explanation of the findings presented in the table will be presented after a short clarification of the indicators of extent of Europeanization and of the dimensions of participation.

\section{Indicators of the Extent of Europeanization}

- Strong Europeanization: CSOs with the strongest Europeanization are those with a commitment to issues the EU deals with. Of particular interest is whether the organizations refer to the EU and whether they actively take part in policy processes at the EU level. Organizations are also regarded as strongly Europeanized if they actively mobilize in 


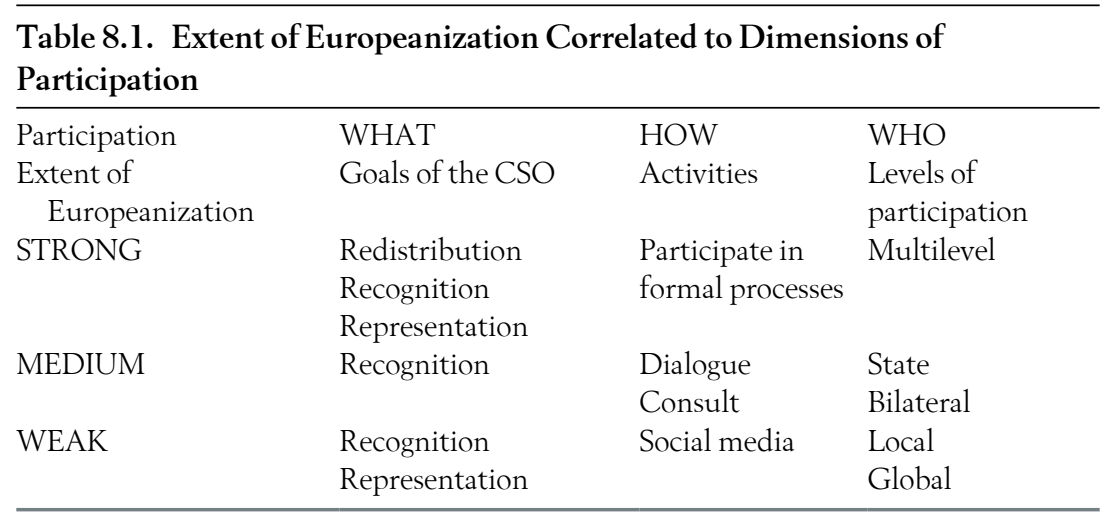

networks and umbrella CSOs at the EU level and if they are mainly funded by the EU and cooperate in projects with CSOs from other EU member states (for instance projects funded by the European Social Fund (ESF)).

- Medium Europeanization: CSOs are categorized as medium Europeanized if they report few activities and commitments toward the EU but have some indirect relations with the EU via other CSOs, such as an indirect membership in the EWL via membership in the SWL.

- Weak Europeanization: CSOs are placed in this category if they have neither a commitment to nor participation in activities directed toward the EU. If they do have any relations, they are indirect relations that are not emphasized by the CSOs.

\section{Indicators of Participation}

The three analytical key questions are operationalized in the following way:

- WHAT refers to the CSOs' main goals. Three alternative categorizations of the CSOs' responses are used; these were introduced in the section of the analytical framework-recognition, redistribution, and representation.

- HOW refers to the CSOs' strategies and actions to influence policymaking.

- WHO refers to levels of representation and principles of inclusion at the local, national, EU, European, or global levels. For the question of who has the ability to make claims at different decision-making levels, the following aspects are considered: membership and representation 
in umbrella CSOs, and invitation to and representation in governmental and intergovernmental organizations. This dimension also contains the CSOs' reactions toward principles of inclusion in policymaking and in the framing of boundaries. The reactions might consist of resistance or acceptance to invitations of participation or they might be manifested in attempts at transforming decision-making processes or affirming the prevailing processes at different political levels.

\section{How Strong Europeanization Correlates with Dimensions of Participation}

CSOs assessed as strongly Europeanized have some activities and relations in common. For instance, they are often active at multiple policy levels: at the national, EU, and UN levels. The SWL is included in this category together with several of its members.

Another common feature among these CSOs is that they are working with a variety of gender issues. The consequence is that all categories of objectives occur for the "what" question, including redistribution, recognition, and representation, although their priorities might vary. Only a few of the interviewed organizations were mainly working with topics related to economic redistribution. Nevertheless, two of the most active CSOs addressed problems of redistribution beyond representation and recognition. The two examples represent professional women, with one representing business in general and the other representing midwives as a specific profession. The Swedish Association of Midwives works for better global reproductive health and to increase the competence of midwives through education and research (Barnmorskeförbundet 2016). The issue of recognition for this CSO referred to professional identity and not particularly to gender identity, and the organization welcomes both women and men as members. The Business and Professional Women's organization (BPW) works toward equal opportunities and equal pay for professional and businesswomen. It also promotes increased representation of women on corporate boards by encouraging women to become leaders; only women are members in the organization (BPW 2015).

Most of these strongly Europeanized CSOs are umbrella organizations with overlapping memberships, which indicates complex relations between CSOs. The BPW's organizational structure is one such example. Together with the SWL it illuminates an interconnected membership: the BPW is a member organization of the SWL, which means that the BPW is related to the other forty-four member organizations in the SWL and to the EWL, and moreover the BPW is represented on the administrative board of the EWL. 


\section{Table 8.2. Crossing Membership between the BPW and SWL and Their Relations to Governmental and Intergovernmental Organizations in a Multilevel Perspective}

\begin{tabular}{|c|c|c|}
\hline Level of organization & Civil Society Organization & $\begin{array}{l}\text { Governmental and } \\
\text { intergovernmental } \\
\text { organization }\end{array}$ \\
\hline National & BPW-SWL & $\begin{array}{l}\text { Committees; Government } \\
\text { Council of Equality }\end{array}$ \\
\hline Europe/EU & $\begin{array}{l}\text { BPWE-EWL; } \\
\text { Social Platform }\end{array}$ & $\begin{array}{l}\text { Council of Europe-EU } \\
\text { Commission (consultative } \\
\text { status) }\end{array}$ \\
\hline Global & BPWI-EWL & $\begin{array}{l}\text { ECOSOC (UN Economic } \\
\text { and Social Council; } \\
\text { consultative status)_- } \\
\text { CEDAW network }\end{array}$ \\
\hline
\end{tabular}

In addition to their overlapping membership, they are also good examples of multilevel organizations as illustrated in Table 8.2.

At the national level the two CSOs have been invited to participate in committees and the Government Council of Equality. At the EU and European levels, both BPW Europe (BPWE; the European umbrella organization of national BPWs) and the EWL had consultative status in the Council of Europe ${ }^{5}$ and the EWL moreover has a consultative function with regular meetings with the $\mathrm{EC}$. Due to their intertwined relations, this also means that BPW has an indirect relation with the EC. The BPWE is an indirect member of the Social Platform-a nongovernmental arena-through its membership in the EWL.

At the international level, the BWP International (BWPI) has had several relations to the UN; for instance, in the International Labour Office the BWPI and EWL have a consultative status in the UN Economic and Social Council (ECOSOC); at the same time the two organizations participated in the Commission on Status of Women of the United Nations (2015) debates. The SWL is also the coordinator of the CEDAW network (one of the UN's human rights conventions), which writes shadow reports to the Swedish government's official reports. This description outlines how two well-organized and well-established women's organizations are working at different political levels in both nongovernmental and governmental networks. With a broad spectrum of objectives, these strongly Europeanized CSOs follow a wide set of activities and strategies to reach their goals.

The International Association for Immigrant Women (2015) is another $\mathrm{CSO}$ assessed to be strongly Europeanized. This is one of thirty members of the Swedish Federation of Immigrant Women's Associations (RIFFI), which 
in addition is a member of the SWL and the UN Association of Sweden along with several other organizations. RIFFI is another Swedish CSO with consultative status on women's issues in the ECOSOC.

These relationships make it relevant to pose the question of whether these kinds of CSOs are better described as networks. It is common that well-established umbrella CSOs have this kind of structure, and of course this differs significantly from the conditions of smaller CSOs (Karlberg and Jacobsson 2015).

The SWL and RIFFI are basically working with matters that can be described, in Fraser's words, as representation and recognition. In particular, it was representation in the EP that was discussed. The EWL, together with its national coordinators, has worked on a campaign to increase women's representation to at least 50 percent of the EP's seats. Stronger inclusion and representation in prevailing political institutions are key issues for the two CSOs. However, all umbrella CSOs are partially the result of how the women's movements in previous periods have addressed problems of representation. Their initiating claims for the right to participate in policymaking at the EU level as well as at the UN level are examples of struggles for reframing representation. However, there is a debate over whether increased possibilities to make claims on gender equality are the result of the efforts of women's movements or if they are an effect of EC policies (Hoskyns 1992). One possible explanation for why the EC wanted to subsidize the establishment of the EWL is its need for better relations with EU citizens (Greenwood 2007).

\section{How Weak Europeanization Correlates with Dimensions of Participation}

CSOs within this category demonstrate different relationships to the EU. Three key varieties of relations to the EU can be distinguished within this category:

1. CSOs with formal relations to the EU but only via indirect membership with the EWL or through another umbrella organization active at the EU level. The EU was not discussed or related to in the interviews despite this indirect formal connection.

2. CSOs with almost no explicit commitments or relations outside Sweden.

3. CSOs with no relations to and no interest in the EU. They are instead strongly engaged in international arenas. Organizations with direct (bilateral) contacts with other CSOs in Europe are included in this 
subcategory. These contacts are not developed in relation to EU institutions or through umbrella organizations at the EU level.

Examples of the first kind of CSOs include active members of the SWL. They cooperate with other members of the SWL, and through this umbrella organization they became members of the EWL, but they did not discuss this relation in the interviews. For example, Women in the Swedish Church (Kvinnor i Svenska Kyrkan) was a member of an organization that was a member of the SWL, which in turn was represented in the EWL. This indirect representation gives rise to the question of whether it is meaningful to talk about participation at the EU level for these kinds of organizational activities and relations. Two out of the fifteen CSOs that were categorized as weakly Europeanized in this study can be described like this. The two examples have access to political institutions at the national level and have been invited to hearings and dialogues. They are mainly working for stronger inclusion in policymaking at the national level and for issues of recognition. They are similar to the dominant kinds of CSOs in the category of medium Europeanized CSOs that are described below, but they are separated from that category due to their very weak commitment to the EU.

The weakly Europeanized CSOs with few relations outside Sweden mostly have commitments to so-called recognition issues. Five organizations were assessed as clearly domestic CSOs; they are mostly active in temporary opinion-making on cultural topics on the Internet. They are weakly organized and are only active when they find it important due to a specific event or situation. Among these organizations are also local units. They are part of organizations that are clearly divided into separate administrative levels where the local organizations are rather independent from the national organization.

Some of the weakly Europeanized CSOs are active either in international cooperation or in bilateral projects with CSOs in other European countries. Based only on interviews with these organizations, one possible reason for CSOs not taking part on their own (but perhaps through indirect membership) in Europeanization is because they prefer other arenas to get in contact with transnational organizations. These kinds of CSOs are more or less questioning prevailing political borders, and some are explicitly condemning the EU. They have directed criticism either toward political border-making or toward political processes due to democratic deficiency. Some of these organizations mostly direct criticism toward the substance of specific EU policies.

Two newly established CSOs with activities on issues mainly regarding recognition and representation; in addition they addressed problems of representation with focus on state borders and the EU level of representation. 
One of them discussed problems for asylum seekers who are affected by EU regulations but who have no chances to influence policies. The other opposes discriminating norms as well as nondemocratic polities, and it took part in actions where unjust regulations or other treatments affected CSOs who struggled for human rights. They are mainly, but not exclusively, active in Europe. These CSOs can be described as social movements that strive for rights through linking local issues to global discourses, but also by discussing global problems at the local level. Consequently, the associations are not related to political institutions at any level but instead rely on campaigns, information, and communication via the Internet as well as temporary relations with other CSOs.

Another CSO problematized the lack of political space for youths in general and demanded more just inclusion in policymaking processes at all levels. Among these weakly Europeanized CSOs were the only transformative CSOs found in the study-in other words, organizations that question the boundaries of political space.

However, there is another kind of CSO in this third subcategoryweakly Europeanized but strongly internationalized CSOs. These are well-established CSOs that aim for better conditions concerning gender relations in general. They are worldwide organizations, but during the interview they did not discuss their formal connection to the SWL or EWL, and they reported no other explicit relations to EU institutions or EU policies. On the other hand, they have had consultative status in the Council of Europe with its focus on democracy and human rights, and they have also been active in the UN. They have several contacts with CSOs in Europe through bilateral projects and conferences; if the concept of Europeanization were to include European networks without any institutional relations to the EU, these six examples would be categorized as strongly instead of weakly Europeanized. These organizations highlight the question of categorization and point out this demarcation problem in the concept of Europeanization.

\section{How Medium Europeanization Correlates with Dimensions of Participation}

This in-between extent of Europeanization is not distinguished by its CSOs' strong interest in the EU, but the CSOs all have relations to the EU that matter in some aspects and were mentioned during the interviews. However, these relations are indirect and not important for the organization. These organizations have in common regular contacts with Swedish authorities, and they are also partially funded by government agencies. 
Among ten organizations categorized as medium Europeanized were six members of the SWL (or members of CSOs that are members of the SWL), which were thereby also more or less linked to the EWL. All in all, eighteen out of the thirty-four interviewed CSOs are members of the SWL on their own or indirectly via an umbrella CSO. Most CSOs with a medium level of Europeanization reported working with recognition questions, and some of them in particular were devoted to recognition of women within the fields of arts and media. This means that they aim for better status of women within the fields of music and media, among others. Focus on recognition often involves activities of norm criticism so as to assess and deconstruct the dominant norms that contribute to the subordination of women.

They have few collaborative projects with CSOs in Europe, whereas some have individual contacts with Nordic CSOs. Some CSOs are well established at the national level, have been invited to take part in dialogues with agencies, and have received grants from agencies such as the Swedish ESF. One example is the Equality Development Center in Skaraborg that cooperates on a regular basis with Swedish regional and local authorities through education in norm-critical methods.

Most of the CSOs within this category inform governmental agencies about gender equality and are respected as experts. Some examples of activities among these CSOs are media monitoring, assessment of the government's gender equality, and assessing the degree of representation of women in museums. Five of these organizations have been regularly invited to meetings organized by the governmental committee on gender equality.

Individuell Mänmniskohjälp (IM) reported a general agreement with SIDA (Swedish International Development Cooperation Agency), which implies specific long-term support by SIDA. IM also reported connections to the EU via membership in the Swedish Confederation for Relief and Development (CONCORD 2016); hence IM was also a member of the European CONCORD that aimed to act as an interlocutor with EU institutions. IM is moreover an example of a $\mathrm{CSO}$ with strong bilateral relations and activities with different countries. The Kvinna till Kvinna Foundation is another $\mathrm{CSO}$ with the status as a development organization with a longterm agreement with SIDA. Compared to IM, it has strong relations and activities toward the EU and is hence assessed as strongly Europeanized.

\section{Concluding Remarks}

The main purpose of this study was to understand why and how Swedish CSOs in the field of gender equality participate at different levels of policymaking and why some women's CSOs are not trying to participate at the EU 
level. Table 8.1 summarizes the findings in the study. The overall question was analyzed using dimensions developed from Fraser's theory of parity of participation. The study demonstrates that participation at different levels differs very much between women's CSOs. Some CSOs are included as experts and advisors in decision-making processes when principles of inclusion are discussed from a gender perspective. It is also clear that some organizations have no relations to EU institutions or to the EU's policymaking processes.

Most of the strongly Europeanized CSOs are well-established umbrella organizations that are active at multiple levels. The strongly Europeanized CSOs are additionally often funded by state projects or through political or labor-market institutions (cf. Hedling and Meeuwisse, chapter 5).

These features are quite contrary to the weakly Europeanized CSOs, which were found to be either part of globalized activities or focused on local issues. Some are indirectly connected to the EU via other organizations, while others are instrumentally constructed as organizations only because of the formal criteria stated by subsidizing agencies. To receive grants, they had to register as formal CSOs. Instead of taking part in ordinary policy processes, some of these CSOs are mostly active in social media and engaged in influencing opinion on temporary topics within civil society.

Regarding what the CSOs focus on, some of the differences between them are connected to the extent of Europeanization. There is a clear preponderance on recognition among the $\mathrm{CSO}$ s, and few $\mathrm{CSO}$ s are engaged in questions of redistribution. Strongly Europeanized CSOs are slightly more evenly divided between the three kinds of substance of justice-redistribution, recognition, and representation-while a majority of the CSOs with medium Europeanization focus on recognition. The weakly Europeanized CSOs are roughly equally working on recognition and representation. Hence, there are some differences among the CSOs even if they are not sharply related to the three extents of Europeanization. One possible explanation for these differences is the close connection between Swedish authorities and CSOs based on expert knowledge. Women's CSOs are invited by national authorities to give advice and to contribute to policymaking with specific knowledge about gender issues, and they are in turn funded by Swedish grants. This mutual dependence might reinforce these CSOs in engaging mainly at the domestic level with questions that are specific for them, such as the recognition of gender (instead of, e.g., questions of redistribution). Such a pattern was in particular found in the category of medium Europeanized CSOs.

The EC has in a similar way encouraged the establishment of a few strong and specialized umbrella organizations at the EU level, such as the EWL, which in turn have contributed to the creation of national coordinators 
like the SWL. In this sense, strong Europeanization among women's CSOs is a result of the EC's need for experts. However, there are other examples of organizations that are already active on the global arena that have taken the opportunity to become active at the EU level when they have found the possibilities to do so. CSOs want to have influence, and the EU wants to strengthen integration with the help of CSOs. However, there is a risk that the EC's relationships and support for some selected CSOs might prevent other CSOs from having a meaningful commitment at the EU level (Stubbergaard 2015).

Applying for financial support from various funds was considered a problem, in particular for small and medium-sized organizations without a secretariat. But even well-established CSOs expressed their frustration with the applications. One problem was that they have to pay for activities before receiving payments from the donor institution.

Some CSOs are active in Europe but are related to the Council of Europe instead of the EU. These CSOs have a strong commitment to Europe beyond institutions and policies linked to the EU, and they bring to the fore a crucial question about the concept of Europeanization (cf. introductory chapter and chapter 1). Should CSOs active in European arenas, which are not institutionally a part of the EU, be described as Europeanized? In this study they were treated as weakly Europeanized. If, instead, all systematic efforts aiming for participating in networks and issues relevant for Europe, as a geographic region, were to be included in the concept of Europeanization, these six organizations obviously have to be categorized as strongly Europeanized. No CSO in Sweden could be assessed as not Europeanized at all because in some way every organization is affected by the EU due to the fact that Sweden is a member state of the EU.

Among internationally active, but weakly Europeanized, CSOs only a few explicitly questioned the border setting and proposed the transformation of political space. Most of the CSOs, regardless of their extent of Europeanization, did not question the system of representation at different levels but rather the inequality in representation. That is to say, they are still claiming inclusion in practice but they are affirming the current division of decision-making levels.

Ylva Stubbergaard is Senior Lecturer in Political Science at Lund University, Sweden. Her research focuses on democracy in theory and practice. Within this field, she is particularily interested in power relations between civil society and public authorities, how citizenship status is constructed, and implications for democracy when relations between politics and public administration change. 


\section{Notes}

1. This chapter uses the term "women's organization" throughout. This means that all organizations and movements in civil society with a focus on gender equality, feminist politics, and women's rights are denominated with the same term. Their specific objectives will instead be categorized according to the three "what" questions elaborated by Fraser-redistribution, recognition, and representation.

2. Thanks to all of the women's organizations that contributed to the study by being interviewed.

3. Scholars have also problematized the risk of reification and essentializing categories of sexes and a uniform idea of women when struggling for recognitions of identities (e.g., Fraser 2005).

4. Many thanks to Sofia Rubertsson for good teamwork and for her great efforts to keep in contact with the CSOs and for carrying out most of the telephone interviews.

5. The Council of Europe aims to strengthen human rights and democratic practices. It has forty-seven member states; twenty-eight of these are also EU member states (Council of Europe 2016).

\section{References}

Barnmorskeförbundet. 2016. Retrieved 31 October 2016, from http://www.barnmorskeforbundet.se/.

Bergqvist, Christina, Per Adman, and Ann-Cathrine Jungar. 2008. Kön och politik. Stockholm, Sweden: SNS förlag.

Bergqvist, Christina, and Sue Findlay. 1999. "Representing Women's Interests in the Policy Process.” In Briskin and Eliasson, Women's Organizing and Public Policy in Canada and in Sweden, 119-46.

BPW. 2015. Retrieved 31 May 2015, from http://www.bpw-europe.org/.

Briskin, Linda. 1999. "Mapping Women's Organizing in Sweden and Canada: Some thematic considerations." In Briskin and Eliasson, Women's Organizing and Public Policy in Canada and in Sweden, 3-49.

Briskin, Linda, and Mona Eliasson, eds. 1999. Women's Organizing and Public Policy in Canada and in Sweden. Montreal, Canada: McGill-Queen's University Press.

Buechler, Steven M. 1995. "New Social Movement Theories." Sociological Quarterly 36, no. 3: 441-64.

Commission on Status of Women of the United Nations. 2015. Retrieved 31 May 2015, from http://www.unwomen.org/en/csw.

CONCORD. 2016. Retrieved 8 December 2016, from https://concordeurope.org.

Council of Europe. 2016. Retrieved 9 June 2016, from www.coe.int.

Cullen, Pauline. 2003. "Sponsored Mobilization. European Union Non-Governmental Organizations, International Governance and Activism for Social Rights." PhD diss. Albany, NY: State University of New York.

. 2010. "The Platform of European Social NGOs: Ideology, Division and Coalition." Journal of Political Ideologies 15, no. 3: 317-31. 
della Porta, Donatella, and Manuela Caiani. 2009. Social Movements and Europeanization. Oxford, UK: Oxford University Press.

de los Reyes, Paulina. 2014. "Introduktion-Inte bara jämställdhet." Intersektionella perspektiv på hinder och möjligheter $i$ arbetslivet. Forskningsrapport till Delegationen för jämställdhet $i$ arbetslivet 2014, no. 34.

de los Reyes, Paulina, and Diana Mulinari. 2005. Intersektionalitet: kritiska reflektioner över (o)jämlikhetens landskap. Malmö, Sweden: Liber.

EC. 2001. European Governance. A White Paper. COM (2001) 428 final. Brussels, Belgium: Commission of the European Communities.

- 2002. Towards a Reinforced Culture of Consultation and Dialogue: General Principles and Minimum Standards for Consultation of Interested Parties by the Commission. COM (2002) 704 final. Brussels, Belgium: Commission of the European Communities.

Eduards, Maud. 2002. Förbjuden handling: Om kvinnors organisering och feministisk teori. Malmö, Sweden: Liber.

Eschle, Catherine. 2001. Global Democracy, Social Movements and Feminism. Oxford, UK: Westview Press.

EWL. 2016. Retrieved 29 May 2016, from http://www.womenlobby.org.

Fraser, Nancy. 2005. "Mapping the Feminist Imagination: From Redistribution to Recognition to Representation." Constellation 12, no. 3.

- 2008. Scales of Justice: Reimagining Political Space in a Globalizing World. Cambridge, UK: Polity.

Fraser, Nancy, and Axel Honneth. 2003. Redistribution or Recognition? London/New York: Verso.

Fraser, Nancy, and Kate Nash, eds. 2014. Transnationalizing the Public Sphere. Cambridge, UK: Polity.

Gamson, William A. 1968. Power and Discontent. Homewood, IL: Dorsey.

— 1990. The Strategy of Social Protest. Belmont, CA: Wadsworth.

Greenwood, Justin. 2007. "Review Article: Organized Civil Society and Democratic Legitimacy in the European Union." British Journal of Political Science 37: 333-357.

Gustafsson, Gunnel, Maud Eduards, and Malin Rönnblom. 1997. Towards a New Democratic Order?: Women's Organizing in Sweden in the 1990s. Stockholm, Sweden: Publica.

Hoskyns, Catherine. 1992. “The European Community's Policy on Women in the Context of 1992." Women's Studies International Forum 15:21-28.

International Association for Immigrant Women. 2015. Retrieved 31 May 2015, from http://www.iffi-stockholm.se.

Johansson, Håkan, and Sara Kalm, eds. 2015. EU Civil Society. Patterns of Cooperation, Competition and Conflict. Basingstoke, UK: Palgrave Macmillan.

Karlberg, Eva, and Kerstin Jacobsson. 2015. "A meta-organizational perspective on the Europeanization of civil society: The Case of Swedish Women's Lobby.” VOLUNTAS: International Journal of Voluntary and Nonprofit Organizations 26, no. 4: 1438-59.

Kohler-Koch, Beate, and Barbara Finke. 2007. "The Institutional Shaping of EU-Society Relations: A Contribution to Democracy via Participation?" Journal of Civil Society 3, no. 3: 205-21.

Manns, Ulla. 2000. "Så skriver vi historia-den svenska kvinnorörelsen ur ett historiografiskt perspektiv." Kvinnovetenskaplig Tidskrift 21, no. 4: 5-27.

Mohanti, Chandra Talpade. 2003. Feminism without Borders: Decolonizing Theory, Practicing Solidarity. Durham, NC: Duke University Press. 
Mokre, Monika, and Anette Borchorst. 2013. "The EU's Gender and Diversity Policies and the European Public Spheres." In Negotiating Gender and Diversity in an Emergent European Public Sphere, edited by Birte Siim and Monika Mokre, 141-160. Basingstoke, UK: Palgrave Macmillan

Nordiskt Forum. 2014. Retrieved 1 October 2016, from http://nf2014.org.

ROKS. n.d. Retrieved 15 May 2015, from http://www.roks.se/.

Rönnbäck, Josefin. 2000. "Rösträttsrörelsens kvinnor: I konflikt och i samförstånd." Kvinnovetenskapligtidskrift 21, no. 4.

Sainsbury, Diane. 2004. "Women's Political Representation in Sweden: Discursive Politics and Institutional Presence." Scandinavian Political Studies 27, no. 3: 65-87.

Sánchez-Salgado, Rosa. 2007. "Giving a European Dimension to Civil Society Organizations.” Journal of Civil Society 3, no. 3: 253-69.

- 2014. Europeanizing civil society; how the EU shapes civil society organizations. Basingstoke, UK: Palgrave Macmillan.

Schmitz, Eva. 2007. "Systerskap som politisk handling. Kvinnoorganiseringen i Sverige 1968 till 1982.” PhD diss. Lund, Sweden: Lund University.

Stoltz, Pauline. 2000. About being (t)here and making a difference: Black women and the paradox of visibility. PhD diss. Lund, Sweden: Lund University.

Strid, Sofia. 2009. "Gendered Interests in the European Union." PhD diss. Örebro, Sweden: Örebro University.

Stubbergaard, Ylva. 2015. "Conflict and Cooperation: Interactions among EU Level Civil Society Organizations in the Field of Gender Equality." In EU Civil Society. Patterns of Cooperation, Competition and Conflict, edited by Håkan Johansson and Sara Kalm 119-136. Basingstoke, UK: Palgrave Macmillan.

Suh, Doowon. 2001. "How Do Political Opportunities Matter for Social Movements?" Sociological Quarterly 42, no. 3: 437-60.

SWL. 2015. Retrieved 10 May 2015, from http://sverigeskvinnolobby.se.

Yuval-Davis, Nira. 2010. “Theorizing Identity: Beyond the 'Us' and 'Them' Dichotomy.” Patterns of Prejudice 44, no. 3. 
Chapter 9

\section{Questioning THE SWEDish MODEL OR EXPORTING IT? \\ IDENTITY EUROPEANIZATION IN THE PROSTITUTION POLICY FIELD}

\section{Gabriella Scaramuzzino and Roberto Scaramuzzino}

This chapter explores how Swedish civil society organizations handle conflicting frames ${ }^{1}$ and identities at the national, European, and international levels in their interaction with other organizations, in particular when such interactions take place within umbrella organizations. Hence the chapter aims at addressing how identity Europeanization relates to organizational Europeanization (see chapter 1) by drawing on theoretical perspectives about framing and identity in social movements (Benford and Snow 2000; Polletta and Jasper 2001) and the organizational theory of metaorganizations (Ahrne and Brunsson 2005).

Interacting with CSOs that are embedded in other contexts, Swedish organizations might encounter frames and identities that are at odds with their own. Furthermore, they might have to interact in contexts where such frames and identities are dominant while their own are interpreted as divergent from the norm. Sometimes such interactions take place inside European or international umbrella organizations of which Swedish CSOs are members. From being accustomed to having many like-minded organizations around them in one context, they might actually end up being isolated and delegitimized in another, or vice versa. Clashes of frames and identities are particularly pertinent in the prostitution policy field (Scaramuzzino and Scaramuzzino 2015). In Sweden, there is a strong consensus against the legalization of prostitution and against defining prostitution as sex work, 
a position that is in contrast with how the issue is viewed in many other European countries. Hence the study focuses on Swedish organizations that are active in the prostitution policy field and are members of umbrella organizations and federations at the European or international level.

While the Swedish model has been criticized abroad, all political parties represented in the Swedish Parliament, and most of the CSOs, are in favor of the Swedish ban on the purchase of sexual services that was introduced in 1999. There is also an ambition to export the model to other countries, not least through European Union (EU) institutions (Scaramuzzino and Scaramuzzino 2015). The Swedish legislation only criminalizes the purchase of sexual services and not sales, and it defines prostitution as a form of violence against women. The focus of the interventions is not on harm reduction, but rather on preventive social work and protection that enables sex-service providers and sex clients to exit prostitution (Scaramuzzino 2014).

Even if the EU has no direct mandate in the prostitution policy field, the past decade has witnessed closer cooperation and coordination between member states concerning trafficking in human beings for sexual purposes. Furthermore, the recent nonbinding resolution in the European Parliament in 2014, in favor of the Swedish model, raises the question of whether we are witnessing the rise of a common European prostitution policy model (Scaramuzzino and Scaramuzzino 2015). Such developments are strongly intertwined with developments at the national level where Sweden plays a key role. The European prostitution policy model might in fact be interpreted as a successful export and translation of the Swedish model into EU institutions. These processes can be understood in light of the increasing regulatory Europeanization of the prostitution policy field.

While there seems to be a strong consensus on these issues in Sweden, conflicting framings can be a challenge for Swedish organizations when interacting at the European level, as shown by the results of the EUROCIV survey (see chapter 3 ). When asked the question, "If your organization is affiliated with or takes part in a European network or federation, how problematic do you experience the following?," all women's organizations in the sample agreed that, "There are too large ideological differences between the participating organizations" (average for all CSOs: 33 percent). Even if such a statement is not necessarily related to the prostitution policy issue, it shows that organizations that work with gender issues, including prostitution (at least in a Swedish context), perceive a clash between their own perspectives and other CSOs that are affiliated with the same umbrella organization.

The empirical material consists of information on websites and social media as well as written online documents and five interviews with representatives from Swedish CSOs. The study on the Internet was informed 
by a connective approach. Starting with studying websites commenting on particular episodes of conflict (described later on in the chapter), we followed links to other websites and posts on Facebook and Twitter over the course of almost two years (December 2012 to August 2014). We explored the content and further connections and performed qualitative content analysis of the texts (cf. Hine 2003; Scaramuzzino 2012). We also found written documents such as open letters and articles that were downloaded from the websites and from social media. The interviews were conducted between April 2013 and March 2015 in Swedish. All empirical material in Swedish has been translated by the authors in the quotations presented in this chapter.

\section{The Swedish Prostitution Policy Model as a Frame}

The prostitution policy field in Sweden has been dominated since the 1970s by a gender perspective and more specifically by a radical-feminist approach. One of the main conquests of the women's movement in this policy field is the ban on the purchase of sexual services-a ban that criminalizes the purchase but not the sale of sexual services. A main argument behind the reform was that by reducing the (male) demand for prostitution, (female) supply would also be reduced (Skilbrei and Holmström 2013). From a broader perspective, the Swedish approach to prostitution might be interpreted in the light of a tradition of an interventionist state with an ambition to eradicate social problems through both preventive and repressive measures, similar to policies on child protection and drug-abuse treatment. This interventionist approach has been argued to pursue social justice and equality (cf. Lorenz 2006) as well as to impose moral norms and regulation on citizens, and especially vulnerable and marginalized groups (cf. Berggren and Trägårdh 2015).

Scaramuzzino and Scaramuzzino (2014) have argued that the Swedish prostitution policy model promotes a gender-equality and gender-policy perspective rather than a social-welfare perspective on the issue of prostitution. Because prostitution is framed as an issue of gender equality, the women's movement has become the natural collective actor for interest representation in the policy field (Erikson 2011). The sex-workers movement has had a weak position in the debate, not least because of lack of resources and legitimacy. The shift of focus from the providers of sexual services to the buyers in the Swedish policy model on prostitution has made their position less relevant, as stated in the most recent evaluation of the law (Swedish Government 2010, 59, authors' translation): "Also in our country, advocates for prostitution argue that you can distinguish between voluntary and 
nonvoluntary prostitution, that adults should have the right to freely sell and buy sex and that the ban on the purchase of sexual services is an anachronistic sexual moral position. From a gender and human rights perspective and with the shift of focus from the supply, i.e., the prostitutes, to the demand, i.e., the traffickers, procurers, and buyers who use other people to satisfy their own or others' sexual needs, the distinction between voluntary and nonvoluntary prostitution becomes irrelevant." Because of the strong consensus in favor of the law and the important symbolic value it has been given for the achievement of gender equality in society, mobilization against the national policy on prostitution has been weak. Until recently open criticism toward the ban has mostly been communicated on the Internet by actors who have been organized in the shadows (Scaramuzzino and Scaramuzzino 2014).

Recent events related to the European and international level have sparked intense debates in Sweden on how to handle conflicting norms and values. The intensity of these debates might partly be related to the symbolic value of the Swedish law both for its supporters and its critics. Two episodes and related debates will be addressed in this chapter. One was around the funding by the Swedish International Development Cooperation Agency (SIDA) to Mama Cash, an organization supporting sex workers' organizations around the world. The other took place among Swedish CSOs around a policy document produced at the international level by the New Yorkbased international organization UN Women advocating against criminalization of sex clients. These two episodes raise questions about how Swedish CSOs handle a national context that is strongly dominated by a framing of the prostitution issue in terms of criminalization of the sex client (and in terms of gender equality) and a European and international arena where other frames are more accepted and clearly competing with the Swedish prostitution model. These policy models or regimes are often labeled as tolerance or legalization models; they consider prostitution as a necessary evil (tolerance) or as legitimate work (legalization), placing transactional sex in the private sphere (tolerance) or the market (legalization) (Scaramuzzino and Scaramuzzino 2015).

\section{Linking Framing, Identity, and Organizational Affiliation}

When considering CSOs as subjects in and objects to identity Europeanization, we need to relate to and understand the ways in which frames and identities are constructed, used, and changed in interaction with other organizations.

In social movement theory, frames have been defined as "action-oriented sets of beliefs and meanings that inspire and legitimate the activities and 
campaigns of a social movement organization" (Benford and Snow 2000, 614). Different framings of prostitution by social movements are not only mirrored by different positions in feminist theory but also by different prostitution policy regimes or models that have been developed over the years. The major divide is between considering prostitution as a form of gender- or economic-based oppression and domination and the view of prostitution as work or a lifestyle that women can choose (Outshoorn 2004, 9; see also Zatz 1997). Different prostitution policy regimes might be seen as specific frames that are institutionalized in national systems and that coexist at national, European, and international policy levels (Scaramuzzino 2014; Scaramuzzino and Scaramuzzino 2015). At the risk of oversimplifying, we might say that these frames define prostitution as sex, work, or violence, and that these different frames are used by organizations active in the prostitution policy field (Scaramuzzino and Scaramuzzino 2014).

Framing also implies identity construction. Framing processes tend to link individual and collective identities as well as to reinforce and support collective identities as such. This is done at a general level by placing different actors in time and space, giving them attributes that put them in relationship to each other, and suggesting lines of action. At a more concrete level, such processes take place when adherents and activists engage in identity discussions but also in communication with the wider society such as press releases and public pronouncements (Benford and Snow 2000).

When social movements spawn formal organizations (so-called social movement organizations), these collective identities tend to become organizational identities. An organization that defines itself as a grassroots organization for sex workers and that makes claims for sex-workers' rights in its pronouncements on their webpage, through Twitter, or on a banner at a demonstration or in the media is framing prostitution in accordance with a specific scheme of interpretation (Scaramuzzino and Scaramuzzino 2015). At the same time, it is constructing its own collective identity and implicitly also the identity of its adherents.

Collective identity might be defined as "an individual's cognitive, moral, and emotional connection with a broader community, category, practice, or institution. It is a perception of a shared status or relation, which may be imagined rather than experienced directly, and it is distinct from personal identities, although it may form part of a personal identity" (Polletta and Jasper 2001, 285). The rise of collective identity as a theoretical concept in the study of social movements has challenged early resource mobilization and political process accounts that strategic choices are merely a product of rational choice. While collective identity might be a matter of strategic choice, the choice of strategies is influenced by collective identity. Identity claims can in fact on the one hand be seen as strategic action (Polletta and 
Jasper 2001, 293-94), as in the case of a sex worker-led organization that is, in addition to claiming an identity, also framing prostitution as work rather than as sex or violence. On the other hand, even if the repertoire of possible strategies is very broad, including demonstrations and lobbying as well as relying on volunteers and/or employing professional consultants, collective identity makes specific strategic actions more viable than other strategies (Polletta and Jasper 2001, 293-94). For a grassroots organization, it is easier to engage in the mobilization and capacity-building of its constituents than it is to hire professional bureaucrats to work with campaigning and lobbying.

Because collective identity is also constructed and negotiated in a social movement organization in relation to the individual identity of its adherents, it might be argued that the same goes for umbrella or metaorganizations. The collective identity of these federations should be seen as a process of identity construction and negotiation between member organizations with their own specific collective identities. When Swedish CSOs become members of national and international networks or federations of organizations, they enter a process of identity construction that involves organizations from other national contexts that might carry different frames and identities.

When it comes to meta-organizations, their identity "is defined by its members to a much greater extent than an individual-based organization" (Ahrne and Brunsson 2005, 437). Because meta-organizations tend to resemble their members, not least because they both consist of organizations, they need to ensure certain homogeneity in terms of both goals and identity. They would, in fact, try to enroll as many organizations as possible of the kind they aim to represent, such as all sex-workers' associations with certain goals and values related to sex workers' rights (cf. Scaramuzzino and Scaramuzzino 2015). Such striving for representativity as well as for homogeneity easily sparks conflicts in meta-organizations both between members and between members and the meta-organization itself; attempts to impose or secure certain similarities are likely to encounter resistance among members (Ahrne and Brunsson 2005).

Homogenization or isomorphism within organizational fields has been highlighted in previous research, especially through the contribution of neo-institutional theory (Di Maggio and Powell 1983). When it comes to the field of prostitution policy, which is mostly regulated at the national level, we can assume the isomorphic processes to be mostly in play among organizations that are active in the same national environment. When Swedish CSOs interact with European or international environments and organizations embedded in other national contexts, we can assume that they will meet a larger variety of organizations and hence a larger variety of collective identities. 


\section{Which Actors? Broadening the Perspective}

While previous research on social movements and civil society in the prostitution policy field has mostly been focused on the mobilization of sex workers (e.g., Andrijasevic et al. 2012; Gall 2007, 2010; Garofalo 2010; Lopez-Embury and Sanders 2009; Scaramuzzino and Scaramuzzino 2015), this study broadens the perspective by also including a focus on other movements and actors. As mentioned, we will focus on two episodes in which prostitution policy-related inputs from the European or international level have sparked debate among Swedish CSOs around conflicting views.

We will also analyze the way in which five Swedish CSOs active in the prostitution policy field and affiliated with European or international networks or umbrella organizations handle different views expressed at different geographical levels. All of the organizations have been involved in at least one of the above-mentioned episodes and are described in table 9.1.

\begin{tabular}{|c|c|c|}
\hline Name & Description & Affiliation \\
\hline Rose Alliance & $\begin{array}{l}\text { Organization for sex and } \\
\text { erotic workers }\end{array}$ & $\begin{array}{l}\text { ICRSE (International } \\
\text { Committee for the } \\
\text { Rights of Sex Workers in } \\
\text { Europe) }\end{array}$ \\
\hline $\begin{array}{l}\text { UN Women Sweden } \\
\text { (Swedish National } \\
\text { Committee for UN } \\
\text { Women) }\end{array}$ & Women's organization & $\begin{array}{l}\text { (United Nations Entity } \\
\text { for Gender Equality and } \\
\text { the Empowerment of } \\
\text { Women) }\end{array}$ \\
\hline $\begin{array}{l}\text { SWL (Swedish Women's } \\
\text { Lobby) }\end{array}$ & Women's organization & $\begin{array}{l}\text { EWL (European Women's } \\
\text { Lobby) }\end{array}$ \\
\hline $\begin{array}{l}\text { RFSU (Swedish Association } \\
\text { for Sexuality Education) }\end{array}$ & $\begin{array}{l}\text { Swedish Association for } \\
\text { Sexuality Education }\end{array}$ & $\begin{array}{l}\text { IPPF (International } \\
\text { Planned Parenthood } \\
\text { Federation) }\end{array}$ \\
\hline $\begin{array}{l}\text { RFSL (Swedish Federation } \\
\text { for Lesbian, Gay, Bisexual, } \\
\text { and Transgender Rights) }\end{array}$ & LGBT organization & $\begin{array}{l}\text { ILGA (International Lesbian, } \\
\text { Gay, Bisexual, Trans, and } \\
\text { Intersex Association) } \\
\text { Transgender Europe }\end{array}$ \\
\hline
\end{tabular}

\section{Funding by Swedish Standards?}

The above-mentioned funding of Mama Cash by SIDA started an intense debate and led to conflicts among Swedish CSOs arguing for or against the 
fact that SIDA was indirectly financially supporting organizations that were advocating for sex work. Some of these organizations were also openly critical of the Swedish prostitution policy. Several organizations, in particular the Swedish Women's Lobby (SWL), and many politicians demanded that SIDA should stop giving aid money to organizations such as Mama Cash. A Swedish politician and member of the European Parliament (MEP) stated (Dagens Arena 2012b), "SIDA's support and aid strengthens the organization [advocating for sex work] as a whole. Money, which according to SIDA should not go to campaigns for prostitution, can of course be redistributed and ultimately used for this purpose anyway. When a Swedish aid program gives money to an organization, it is also legitimizing their work. SIDA's action is at best an example of tremendous naivety and in the worst case a lack of understanding of how the sex slave trade actually works in the world today."

The critique that SIDA's funding of Mama Cash was supporting and legitimizing the idea that women's bodies could be bought was echoed by a representative from the SWL: "Mama Cash's view on prostitution is contrary to the Swedish stance that it is a form of violence to purchase another person's body for one's own pleasure" (OmVärlden 2012).

SIDA defended their actions and the funding of Mama Cash: "Mama Cash is doing a great job and they are one of the few actors that really reach out to these grassroots' organizations for extremely vulnerable women" (Dagens Arena 2012a). The Swedish Association for Sexuality Education (RFSU) also went public and officially supported SIDA's position, stating that several of the women's organizations that RFSU was cooperating with got support from Mama Cash and would not survive without their help: "For RFSU this in not about promoting sex work. This is about assuring that people get their fundamental rights such as not to be harassed or raped by the police, to be able to report when having been victims of crimes, and getting access to condoms and safe sex or medical care when they need it" (RFSU 2012).

This short description of different positions shows conflicting views within Swedish civil society on whether Swedish public funding should support organizations that carry frames and identities that are at odds with the Swedish model. It was also revealed that Mama Cash not only gave funds to sex workers' organizations abroad, but also financially supported Rose Alliance, a Swedish (domestic) sex workers' organization, through a specific fund aiming at supporting groups that worked with sex workers' rights (OmVärlden 2012). When it was revealed that Rose Alliance also received money from the Swedish state, the conflict became even more intense, as described by a representative for the organization (interview Rose Alliance): "It was a nightmare, and ended up as a personal attack. Journalists from 
newspapers called, and I was accused of being a recruiter for the sex industry. It was bizarre. We received money from Mama Cash, but the contract stated that SIDA's money may not be given to sex workers' organizations. Their argument was that SIDA's money strengthened Mama Cash. But RFSU was really good. They went out straight away and defended it." According to the interviewee, Rose Alliance received a small amount: twenty thousand euros a year. It was not enough to rent an office, but they could use it to strengthen their work as well as their cooperation with other organizations at the European level. Critics accused SIDA of being naive and of indirectly supporting Rose Alliance in Sweden. They stated that if any organization for and by prostitutes should receive support in Sweden, it should have been PRIS (Prostitutes' Revenge in Society), which supported the Swedish view of prostitution as violence against women and, unlike Rose Alliance, was supportive of the Swedish sex purchase law (OmVärlden 2012).

\section{Swedish Organizations Interacting on Different Geographical Levels}

The episode above shows that when Swedish CSOs interact at supranational levels (European or international) they might meet frames and identities that have a weak position in a Swedish context.

\section{Defending and Exporting the Swedish Model}

For organizations such as the Swedish National Committee for UN Women (UN Women Sweden) and the SWL, this means interacting in environments where their framings and identities might be challenged to a greater degree than they are used to in Sweden.

The SWL described prostitution, trafficking for sexual purposes, and surrogate motherhood as being among the most important issues to oppose to when it comes to violence against women. The fight against these phenomena was at the core of the organizations' framings and identities, and they argued that a woman's body is not, and should never be seen or treated as, a commodity: "This is a very important issue for us ... and for the women's movement" (interview SWL).

In following these organizations' activities on the Internet and interviewing their representatives, four sets of beliefs and meanings could be identified. The first is to curb the demand, following the logic that if there is no demand for purchasing sex or for purchasing babies from women who rent their bodies there will be no prostitution, trafficking, or surrogacy: 
"Our main point is to address the demand because it is the very key to the issue" (interview UN Women Sweden). The second is that prostitution and trafficking cannot be separated because they are two sides of the same coin: "If there is no prostitution, there will be no trafficking, and vice versa" (interview UN Women Sweden). The third is that it is important to eliminate poverty and not to accept poverty as a reason to further the oppression of women, for example by defining and treating prostitution as work or tolerating surrogacy. The fourth is that no one has the right to have a child at the expense of someone else.

These four sets were described not only as important for how UN Women Sweden and the SWL perceive themselves, but also as important for guiding their lines of actions and constructing the identity of its adherents. The biggest challenge was reported to be the new sex industry that according to these organizations was continuously breaking new ground: "The sex industry often operates undercover and tries to influence organizations in order to make them use the language of 'sex work,' even within the UN system" (interview SWL). According to the interviewee, while selling sexual services could not in any way be viewed as work, the sex industry was methodically pursuing such an agenda and with huge financial resources.

But the new sex industry was described as having more influence on organizations at the EU and international levels, where the SWL also experienced views that were more conflicting. According to the representative for UN Women Sweden, both in the EU and the UN there are many men in positions of power and responsibility and, like in society at large, there are also within these systems male power structures obstructing the fight against prostitution. In fact, putting the issue on the agenda in the EP required a strategic move of reminding the mostly male audience of this, as recalled by the interviewee (interview UN Women Sweden): "A female police detective said: 'Yes, every month the European Parliament moves to Strasbourg and women are moved there, by bus, to serve them.' And it was like dropping a bomb as journalists from newspapers from all over the world were present. So, when we eventually wrote our report about what had to be done, there was no man who dared to vote against it." According to the interviewee, it is not only male politicians in the EP but also, and even foremost, men in the third world who do not see prostitution as an important issue to rise up and fight against. Both the SWL and UN Women Sweden work at both the European and international level lobbying for women's rights. They also cooperate with many organizations around the world on prostitution and other issues related to women's rights and gender equality. They stated that they have also been very successful in translating and promoting the Swedish model at the EU level through umbrella organizations such as the EWL and public institutions such as the EP and through international 
cooperation with women's organizations in other European countries: "It is clear that the attempt to legalize prostitution in order to control the market doesn't work. Experiences from Germany and the Netherlands show that they have huge problems with trafficking and other types of organized crime that come with a legalized prostitution market" (interview SWL).

From a strategic-choice perspective, this might be interpreted as an effective strategy against an industry that had Europeanized its exploitation of women-namely to Europeanize the Swedish model by exporting the Swedish policy on prostitution to the rest of Europe.

\section{Questioning and Criticizing at Home and Abroad}

Compared to UN Women Sweden and SWL, both RFSU and the Swedish Federation for Lesbian, Gay, Bisexual, and Transgender Rights (RFSL) presented frames and identities that were more at odds with the Swedish model. According to the representative for RFSU, it is important to reduce the demand for sexual services but also to defend the rights of the people who are selling sexual services: "We want Sweden to adopt a harm-reduction perspective" (interview RFSU). While there were different ways of understanding and naming the phenomenon within RFSU, including prostitution and sex work, the majority of the congress of June 2015 chose to adopt the term "transactional sex."

Instead of equating prostitution and surrogacy, the representative for RFSU compared prostitution and abortion. Accordingly, the interviewee argued against extending the ban on the purchase of sexual services to transactions made abroad, something many CSOs (including the SWL) had been pushing for. The argument was that it would be a dangerous logic in the same way as if countries like Poland would make it illegal for women to come to Sweden to have an abortion or if Russia decided to make it illegal for LGBT persons to advocate for gay rights when they were in Sweden.

RFSL's activities in the prostitution policy field were not described as pushing for a change of the law. However, the organization had expressed its position in different forums (e.g., investigations on behalf of the government), including their critique of the negative consequences of the law on HIV prevention and the need for better support for people selling sexual services: "When our opinions have been requested, we have simply brought them forward, but we have not given priority to actively pursuing a legislative change" (interview RFSL).

The legislation on prostitution was not a priority for RFSU either, even if they found themselves at the center of an intense debate because of a report they had commissioned. The conclusions were used to criticize the 
Swedish prostitution policy, even if criticizing the law was not the original intention of the report (interview RFSU):

This debate that has flared up has grown to unreasonable proportions. It is a part of our work, but we work with so many other questions as well. Some of the biggest questions we address internationally are the right to abortion, maternal mortality-every day 800 women die because of maternal mortality. We work with HIV, with masculinity and how to tackle the traditional male role to curb violence against women; we work for the right to have access to sexual education, access to contraception and so on. We have also been advocating for the implementation of harm-reduction measures in Sweden for people involved in transactional sex, both the buying and selling part. When it comes to advocacy, we have, however, not put so much effort in either attempting to export the Swedish sex purchase law or trying to discourage the export of it. At the international level we have partner organizations in many countries, and some of our partners work actively with people who sell sex. So, in that way you could say that we also work with the issue internationally. We support these partner organizations, which are usually member-based and grassroots organizations, financially and with organizational knowledge and so on.

While both RFSU and RFSL have chosen a framing of the prostitution issue that is more critical to the Swedish model, their organizational identities are less bound to this issue. They both, however, consider themselves as feminist organizations that work for gender equality. According to the representative for RFSL, in the global feminist movement it is much easier to find organizations that work with sex workers' rights and have an opposite approach than the Swedish feminist movement. Globally, it is much more common that the feminist movement is fighting to destigmatize sex work and ensure fair treatment and human rights. At big international conferences about HIV prevention "the 'Swedish model' is sometimes seen as something very negative" according to the interviewee from RFSL. Seen from a global perspective, the transgender movement and the sex workers rights' movement are also closely linked because many transgender persons are involved in the sex industry and are in a vulnerable position, according to the representative from RFSL.

The same interviewee described a political climate where "it has become more difficult to have a discussion about prostitution in Sweden. People and organizations that are skeptical or that question the sex purchase law are placed in the corner together with those who do not care about women's rights" (interview RFSL). In a Swedish context, the RFSU and RFSL are sometimes treated as antifeminist, according to the representatives, especially when they question the positive effects of the legislation or demand more supportive measures for, and less stigmatization of, people selling sex: "We have a feminist and intersectional approach, which means that we also 
acknowledge other power structures besides gender. I am as much a feminist as they are, and IPPF [International Planned Parenthood Federation] is a feminist organization. But you draw different conclusions depending on what perspective you have" (interview RFSU).

RFSU's framing of prostitution and identity are sometimes at odds with the general dominant frame in Sweden, but sometimes also with the frames at the European and international levels, according to the interviewee. In these settings the RFSU is not perceived to be sufficiently critical of the Swedish sex purchase law. The representative for RFSU could see some positive effects with the Swedish model, whereas both IPPF and the Joint United Nations Programme on HIV/AIDS (UNAIDS) have been very critical. The representative described how the RFSU has been internationally engaged in projects concerning sexual and reproductive health and rights for many years, stating that RFSU's extensive international contacts in many different countries has influenced how they see things. While the organization strives to have an international perspective, it is also influenced by how prostitution has been framed in the Swedish context. Compared to RFSU, RFSL seems to be less active in the prostitution policy field at the European level. RFSL is affiliated with the umbrella organization ILGA Europe (International Lesbian, Gay, Bisexual, Trans, and Intersex Association), but ILGA has not taken any stand on the issue according to the interviewee: "They do not have any big and clear platform for that yet. It is not their focus, however" (interview RFSL). Transgender Europe, to which RFSL is also affiliated, has been more active and has taken a clear stand against EWL's campaign "Together for a Europe free from prostitution," which EWL launched in 2011.

It is difficult to assess to what extent the choice by RFSU and RFSL not to focus on legislation was a strategic choice due to the harsh political climate at the time. However it is clear that Rose Alliance had made the choice of not engaging in prostitution policy issues at the domestic level, even if the issue, for an organization by and for sex workers, was indeed relevant for the organization's framing and identity (interview Rose Alliance): "After the sex purchase law was introduced, it was very difficult to work in Sweden. If you said anything, even if it was not something dreadful, and expressed that sex workers were feeling very bad, nobody would listen. There was no room for it at the time. But about five years ago, we changed our name from ROSEA to Rose Alliance, and now we are trying to become a member-based organization." Because it was so difficult to advocate for sex workers' rights in Sweden at the time, ROSEA (now Rose Alliance) started to engage more on the European level. For example, the organization participated in the European conference Sex Work, Human Rights, Labour and Migration, which was held in Brussels in 2005. This conference was also mostly funded 
by Mama Cash (interview Rose Alliance). One of the goals of the conference was to start a European network of sex workers' organizations as well as of individual sex workers and supporters, both individuals and organizations. "The second day 80 allies came; it was everything from Amnesty International to the International Labour Organization, organizations that we didn't have any problems cooperating with" (interview Rose Alliance). After the conference the International Committee for the Rights of Sex Workers in Europe was established as a European meta-organization with Rose Alliance among its members.

After facing difficulties making its voice heard in Sweden, Rose Alliance made the strategic choice to not engage in prostitution policy but rather in harm-reduction social work and access to rights for their constituencies. However, Rose Alliance continued to perceive the supranational level as much less hostile to its framing of prostitution and its organizational identity and used that level strategically to strengthen its position at the national level in Sweden: "The EU has shown quite clearly that they are not afraid of giving financial support to sex workers' organizations. For example, we got money from the Leonardo program [Leonardo da Vinci Programme for vocational education and training, replaced by Erasmus+ program]" (interview Rose Alliance), which, according to the interviewee, resulted in other projects at the EU level. Such funding also made it possible to start a network and a web-based platform for sex workers' organizations, as well as other users' organizations: "The website provides an opportunity to be seen and to organize" (interview Rose Alliance). The aim was to increase the quality of life for many different marginalized groups in Europe, such as sex workers, drug users, migrants, MSM (men having sex with men), and people living with HIV and AIDS by improving their access to medical and social services.

Rose Alliance's work and cooperation with other organizations at the supranational level has made it much easier to also get funding in Sweden, according to the representative: "It is much easier to go back to Sweden and ask for money when we can say, 'Look, we have done all this.' This was not possible ten years ago. It has been a big change, because of this, and we are now starting to see a strong grassroots movement in Sweden. This is a direct result of the EU" (interview Rose Alliance). It is clear that Rose Alliance, RFSU, and RFSL tend, at the national level, to focus on the help and support that people with experience of prostitution were in need of rather than on the legislation on prostitution, in their framing. Even if it is not necessarily in the organizations' intentions to avoid conflict, these frames, which were inspired and supported by the debates at the European and international levels, have been more viable and less controversial in Sweden than directly criticizing the law. 


\section{When New York Calls}

The UN Women's "Note on Sex Work, Sexual Exploitation and Trafficking" sparked conflict among Swedish CSOs. In the note, which was published in October 2013, the New York-based organization stated that it was important not to consider sex work in the same way as trafficking or sexual exploitation and that it was important to recognize the right of all sex workers to both enter and leave this activity. They also advocated for not criminalizing sex workers or clients (UN Women 2013a): "The views of UN Women on the subject are grounded in the relevant human rights principles and provisions, intergovernmental normative frameworks, and the best available scientific and epidemiological evidence. UN Women is attentive to the important input of civil society across the wide spectrum of opinion that pertains to the subject."

With this note UN Women framed prostitution and trafficking for sexual purposes as different phenomena that should be tackled differently. To gain legitimacy for how they framed these issues, they claimed that both science and civil society supported their view. Many Swedish CSOs (including the SWL and some of its members) reacted critically to this statement and demanded that UN Women Sweden should distance itself from the headquarters of UN Women in New York. UN Women Sweden reacted by criticizing the meta-organization of which they themselves were a member.

This episode shows how the statement by UN Women's office in New York intruded on its member organizations' autonomy and thus created competition and tension within the organization (cf. Karlberg and Jacobson 2014): "It made us choke when we saw that the letter from the headquarters in New York was an argument for sex work, and we exploded" (interview UN Women Sweden). UN Women Sweden wrote a letter expressing concern about the content of the note and the fact that it was brought to their attention by other organizations (UN Women Sweden 2013):

We refute vividly both the way the note has been brought to our attention and its political standpoint. On issues which are controversial the UN Women are not supposed to express an opinion. This position was communicated to the chairperson of UN Women National Committee Sweden, about a year ago, when she asked about the position of UN Women on surrogate motherhood. UN Women responded that it does not express an opinion on controversial issues, but leaves it to each member state to form an opinion. From the present note, we find that UN Women has made a policy change on an issue that divides the world, and where the Northern European and the global women's movement fight for recognition of fundamentally different values. 
As the quotation shows, there were conflicting framings within the meta-organization, framing prostitution either as work or as gender-based violence; these framings were fundamentally different and perhaps irreconcilable. The conflict can be interpreted as identity management of inherent conflicting forces within a meta-organization. All members of the meta-organization in fact claim to be unique at the same time as the member organizations are dependent on each other and based on similarity. The biggest sacrifice for the member organizations would be to lose their autonomy (Karlberg and Jacobson 2014). As the quotation shows, one solution for the meta-organization could be not to express an opinion when it comes to controversial issues. In the responding letter, UN Women Sweden, together with their "sisters and brothers around the world," presented their alternative frame: "We are numerous actors who have worked with this issue for many decades. We have been very successful in our fight against prostitution and can therefore not accept the views expressed in the note by UN Women" (UN Women Sweden 2013).

In this case, and because of how important the issue of prostitution and trafficking is for the identity of UN Women Sweden, the conflict became serious: "We have reacted and it would be devastating if UN Women in New York, our top organization for women's right, started to take a stand for the sex industry. If they would do so, I think many national committees would speak up and leave the organization" (interview UN Women Sweden). Other organizations, such as the feminist organization Women's Front (Kvinnofronten), also wrote open protest letters to put pressure on UN Women to retract their statement.

In the responding letter the international organization UN Women tried to clarify its position: "UN Women has not issued any official statement on sex work. We have sent an email to some NGOs who have written to UN Women raising their concerns on the issue of criminalizing or decriminalizing the 'sex industry'" (UN Women 2013b). This statement can be interpreted as an attempt by the headquarters in New York to step back to keep the meta-organization together. After the protests both outside and within the meta-organization, they had to emphasize that this was not an official statement, as explained by a representative of UN Women Sweden: “Otherwise the strong UN Women's National Committees would explode. So I think they are trying to find some kind of middle way, and some kind of explanations. But, who knows, it's the same male power structure within the UN as in the rest of the society" (interview UN Women Sweden). 


\section{Affiliation to Meta-Organizations}

As the example above shows, when interactions between organizations at the supranational level take place inside the meta-organizations to which they are affiliated, conflicting frames and identities need to be handled within the organization. In these processes of organizational Europeanization, the interviews indicated three important issues to be handled in such interactions.

First, the extent to which the policy issue is central for the organizations' identities plays an important role. For UN Women Sweden and the SWL the issue was in fact central. UN Women Sweden had even come into conflict with its meta-organization on the framing of prostitution as sex work. The SWL, in turn, had pushed for and been successful in the implementation of its own framing and identity in the meta-organization of which it was member,: “The European Women's Lobby has taken a stance for the Swedish model even though the German Women's Lobby disagrees. The German Women's Lobby is, however, not actively working against it. But it is the same as when the European Women's Lobby took a stance for the European directive on maternity leave. The Swedish Women's Lobby is not supporting this proposal because we want an individualized parental leave system. So we are not supporting it, but we are not working against it either. So you see we are not pursuing the issue" (interview SWL). This shows how, in a meta-organization, the member organizations sometimes have to step back on certain issues in order to not create too much internal tension.

In the cases of RFSU and RFSL, prostitution has not been a central issue for their meta-organizations which has made RFSU's position, which is considered too positive toward the Swedish model, unproblematic for the meta-organization. There was, however, a tendency in the IPPF to start addressing the prostitution issue and to find a common stance, according to the representative (interview RFSU), which might in fact force RFSU to take a clearer position for or against the Swedish model. Rose Alliance seems to share its meta-organization's overall frame and identity.

Second, the interaction depends on how the domestic organizations are affiliated with international or European meta-organizations and the kinds of relationships that such membership implies. UN Women Sweden is organized like a chapter of its meta-organization and is thus in need of coordinating its frames and identity. The tension between the supranational and the national level cannot be ignored and needs to be addressed in one way or another. UN Women Sweden might have to reconsider its affiliation if the distance between the two organizations becomes too wide. The SWL has not been so concerned by the fact that some members of the EWL have 
been critical of the Swedish law because their own position seems to be dominating in the meta-organization and thus not challenged.

The third issue relates to the position of the affiliated members in the meta-organization. All members do not have the same status in the meta-organization, and all interviewees expressed that they perceived having a strong position in the meta-organization. Most importantly, they described that they are autonomous and have the possibility to act on their own. This was reported to be especially true for RFSU, which can, according to the representative, act together with IPPF but can also decide to act on its own. This position seemingly does not require RFSU to coordinate its framing of the prostitution issue and its identity with IPPF.

\section{Conclusions}

Interacting with organizations at the European and international levels can provide both opportunities and challenges for Swedish CSOs. Challenges are particularly evident in a polarized policy field such as prostitution/sex work in which different framings and identities can clash and lead to conflicts. Some organizations can perceive the supranational level as liberating, while perceiving the domestic level as oppressive. These organizations might choose strategies that reduce conflicts at the national level. Other organizations that perceive the supranational levels as more hostile might instead try to export their frames and identities abroad. This study suggests that it is easier to preserve frames and identities that are dominant at the domestic level and at odds with the supranational level when one is interacting in these contexts. The opposite situation-in other words, upholding frames and identities that find support abroad when interacting at the domestic level where these are more at odds with the general political culture-seems to be more difficult.

Meta-organizations can provide a more safe and predictable environment for interaction where some of the potential clashes and conflicts can be handled within formalized democratic procedures. This does, however, raise issues of adaptation due to the high level of homogeneity required by the meta-organization to uphold at least some common ground when it comes to framing and identity.

We argue that the Swedish prostitution policy model is the product of both the traditional Swedish way of handling social issues and the women's movement's effort to frame the issue from a specific gender perspective. The study shows that, through organizational Europeanization, new frames and identities are imported in the domestic field (identity Europeanization) and that this can spark adaptation but also conflicts. These processes create 
opportunities both for questioning the Swedish prostitution policy model at home and for exporting it abroad.

Gabriella Scaramuzzino is Researcher at the School of Social Work at Lund University, Sweden. Her research interests are in the areas of prostitution, civil society, and digitalization. She is currently studying how the Internet and social media affect mobilization and organization in civil society.

Roberto Scaramuzzino is Researcher at Lund University, Sweden. His research interests include changes in the welfare and integration systems and the role of CSOs in different countries. He has been engaged in comparative studies of mobilization in the migration and prostitution policy fields in Sweden and Italy, and at the EU level. He is currently working in a research program on civil society elites in Europe.

\section{Note}

1. A frame is a cultural and cognitive system or scheme of interpretations that organizes and structures individuals' and groups' experiences and defines the significance of the events that are within the frame and hence guides actions (Goffman 1974).

\section{References}

Ahrne, Göran, and Nils Brunsson. 2005. "Organizations and Meta-organizations." Scandinavian Journal of Management 21, no. 4: 429-49.

Andrijasevic, Rutvica, Claudia Arandau, Jef Huysmans, and Vicki Squire. 2012. "European Citizenship Unbound: Sex Work, Mobility, Mobilization." Environment and Planning D: Society and Space 30: 497-514.

Berggren, Henrik, and Lars Trägårdh. 2015. Är svensken människa?: gemenskap och oberoende i det moderna Sverige, 2nd ed. Stockholm, Sweden: Norstedts.

Benford, D. Robert, and David A. Snow. 2000. "Framing Processes and Social Movements: An Overview and Assessment." Annual Review of Sociology 26: 61 1-39.

Dagens Arena. 2012a. "Sidamiljoner till lobbyister för sexhandel." Retrieved 17 December 2012, from http://www.dagensarena.se/innehall/sidamiljoner-till-lobby ister-for-sexhandel/.

— . 2012b. "Anna Hedh (S) Stoppa biståndspengarna till Mama Cash.” Retrieved 17 December 2012, from http://www.dagensarena.se/opinion/stoppa-bistand spengarna-till-mama-cash/. 
Di Maggio, J. Paul, and Walter W. Powell. 1983. "The Iron Cage Revisited: Institutional Isomorphism and Collective Rationality in Organizational Felds." American Sociological Review 48: 147-60.

Erikson, Josefina. 2011. "Strider om mening: en dynamisk frameanalys av den svenska sexköpslagen.” PhD diss. Uppsala, Sweden: Uppsala University.

Gall, Gregor. 2007. "Sex Worker Unionization: An Exploratory Study of Emerging Collective Organization." Industrial Relations Journal 38, no. 1: 70-88.

—. 2010. "Sex Worker Collective Organization: Between Advocacy Group and Labor Union?" Equality, Diversity and Inclusion 29, no. 3: 289-304.

Garofalo, Giulia. 2010. “The Political Economy of Sex Work in Europe.” PhD diss. London, UK: University of London.

Goffman, Erving. 1974. Frame Analysis: An Essay on the Organization of Experience. New York, NY: Harper and Row.

Hine, M. Christine. 2003. Virtual Ethnography. London, UK: SAGE.

Karlberg, Eva, and Kerstin Jacobson. 2014. "A Meta-organizational Perspective on the Europeanization of Civil Society: The Case of the Swedish Women's Lobby." VOLUNTAS: International Journal of Voluntary and Nonprofit Organizations 26, no. 4: 1438-459.

Lopez-Embury, Susan, and Teela Sanders. 2009. "Sex Workers, Labor Rights and Unionization." In Prostitution: Sex Work, Policy and Politics, edited by Teela Sanders, Maggie O'Neill, and Jane Pitcher, 94-110. London, UK: SAGE.

Lorenz, Walter. 2006. Perspectives on European Social Work: From the Birth of the Nationstate to the Impact of Globalisation. Opladen, Germany: Barbara Bodrich.

OmVärlden. 2012. "Lobby för sexarbete får Sidabidrag." Retrieved 17 December 2012, from http://www.sida.se/OmVarlden/Varlden/Briefing/Lobby-for-sexarbe te-far-Sidabidrag/.

Outshoorn, Joyce. 2004. "Introduction: Prostitution, Women's Movements and Democratic Politics." In The Politics of Prostitution: Women's Movements, Democratic States and the Globalisation of Sex Commerce, edited by Joyce. Outshoorn, 1-20. Cambridge, UK: Cambridge University Press.

Polletta, Francesca, and James M. Jasper. 2001. "Collective Identity and Social Movements." Annual Review of Sociology 27: 283-305.

RFSU. 2012. "Viktigt med stöd till världens mest utsatta kvinnor." Swedish Association for Sexuality Education, Sweden. Retrieved 17 December 2012, from http://www. dagensarena.se/opinion/rfsu-viktigt-med-stod-till-varldens-mest-utsatta-kvinnor/.

Scaramuzzino, Gabriella. 2012. "Ethnography on the Internet-An Overview." In Pondering on Methods-A Variety of Methodological Concerns, edited by K. Jacobsson and K. Sjöberg, 41-54. Lund, Sweden: Lund University.

—. 2014. Sexsäljare och sexköpares kollektiva handlande på Internet: En svensk "fuckförening"? PhD diss. Växjö, Sweden: Linnaeus University Press.

Scaramuzzino, Gabriella, and Roberto Scaramuzzino. 2014. "Violence, Sex or Work? Claims-making against the Swedish Ban on the Purchase of Sexual Services on the Internet." Social Work and Society 12, no. 1: 1-15.

Scaramuzzino, Roberto, and Gabriella Scaramuzzino. 2015. "Sex Workers' Rights Movement and the EU: allenging the New European Prostitution Policy Model." In EU Civil Society: Patterns of Cooperation, Competition and Conflict, edited by Håkan Johansson and Sara Kalm, 137-154. Basingstoke, UK: Palgrave Macmillan. 
Skilbrei, May-Len, and Charlotta Holmström. 2013. Prostitution Policy in the Nordic Region: Ambiguous Sympathies. Farnham, UK: Ashgate.

Swedish Government. 2010. Förbud mot köp av sexuell tjänst. En utvärdering 1999-2008: betänkande. SOU 2010:49. Stockholm, Sweden: Fritze.

UN Women. 2013a. "Note on Sex Work, Sexual Exploitation and Trafficking." October 9. UN Women. New York, NY.

- 2013b. "UN Women's Answer to Protest Letters about Their Note on "Sex Work" and Trafficking." October 30. Swedish National Committee for UN Women. New York, NY.

UN Women Sweden. 2013. "Letter to UN Women Executive Director Phumzile Mlambo-Ngcuka." October 23. Swedish National Committee for UN Women. Sweden.

Zatz, D. Noah. 1997. "Sex Work/Sex Act: Law, Labor, and Desire in Constructions of Prostitution." Signs 2: 277. 
Chapter 10

\title{
Promoting CONSUMER RightS IN SWEDEN BY LOBBYING AND AWARENESS-RAISING ABROAD
}

\author{
Anna Meeuwisse and Andreas Vilhelmsson
}

Increased interaction between state and civil society and a growing dissatisfaction with professional paternalism have paved the way for the rise of consumer groups of different kinds as potential drivers of democratization within the health domain (Löfgren, de Leeuw, and Leahy 2011). The numbers of health consumer and patient organizations are rising across Europe, and health consumer interests are more often being represented at a political level (Wehling, Viehöver and Koenen 2015). However, patient advocates often find it difficult to present a strong, united front that gains a hearing in national policy deliberations (Tomes and Hoffman 2011). Nevertheless, there is some evidence that health consumer organizations can influence policy and reform, especially when they work in concert with other interests (Baggott and Jones 2014). Much depends on how these organizations are affected by, and interact with, the political context in which they are situated and on the alliances they build with other policy actors. In light of the increasing significance of international relations and transnational advocacy networks for social development in general, it is important to pay attention to the political role of activist organizations as both domestic and international actors (Keck and Sikkink 1998).

The aim of this chapter is to investigate how the Consumer Association for Medicines and Health (KILEN), a small Swedish health consumer organization addressing the issues of drug dependency and consumer reporting 
of adverse drug reactions, throughout the years and with varying degrees of success made use of political opportunities domestically as well as at the European and international levels to contest the dominance of Swedish corporative actors and structures. KILEN addressed controversial medical issues and was often challenged by powerful professional and political interests in Sweden at the national, regional, and local levels. KILEN tried to navigate the political landscape by using different political opportunities at various levels in order to contest the dominance of national corporative actors and structures.

At times KILEN had some support from various political stakeholders at both the central governmental level and at the county level, but it always had to fight for its existence; eventually it lost state funding in 2007 and had to dismantle the following year. A study of KILEN thus provides insights into the strategies available for domestically contentious organizations and might contribute to the discussion concerning how different levels might be strategically played depending on the specific political opportunities at hand. Feeding back to the theoretical chapter in this book, we especially pay attention to the significance of various aspects of regulatory, financial, and discursive Europeanization in this particular case (see chapter 2). In order to get an understanding of KILEN and the dynamics at play, key persons that have been involved in, collaborated with, or reported on KILEN have been interviewed. These include the two founders of KILEN (and who periodically constituted the bulk of the organization) and a few politicians, journalists, and representatives from the national and international scientific communities. We conducted nine interviews between February 2014 and October 2015. We have also studied texts from KILEN's official website, proposals and decisions from the Swedish Parliament, and proposals from the European Parliament (EP) as well as Swedish newspaper articles and medical journals that have highlighted the organization's stance and activities.

\section{A Political Opportunity Approach}

This study draws on the so-called political opportunity approach that was developed among social movement theorists in order to grasp the mechanisms and factors that facilitate or hinder movements from accomplishing their political and social goals within a specific polity (e.g., Eisinger 1973; McAdam 1996; Tarrow 1988). This approach highlights how the political context affects movements' possibilities to mobilize, influence policies, and contribute to social and political change. Synthesizing the dimensions of political opportunities that researchers on the subject have included in their 
operationalization of the concept, Doug McAdam $(1996,27)$ has suggested the following consensual list:

1. The relative openness or closure of the institutionalized political system

2. The stability or instability of the broad set of elite alignments that typically undergird a polity

3. The presence or absence of elite allies

4. The state's capacity and propensity for repression

At the heart of the political opportunity approach is the view that exogenous factors might either enhance or delimit prospects for certain arguments or claims, particular strategies of influence, or the ability to affect mainstream institutional politics and policies (Meyer and Minkoff 2004). It focuses on how a movement's interaction with the political system and the broader political context can lead to both successes and failures for the movement, and tries to identify the concrete characteristics of the political system and/or context that provide opportunities or impose threats. In other words, it acknowledges how factors residing in the political system and the broader political context can work either in favor of or against movements that mobilize for a certain cause. The approach can be used to understand the strategies and actions of a variety of actors, which are usually social movements but can also include different types of interest groups.

The political opportunity approach has often been used to discuss political opportunities on the national level, but it is also important to recognize the increasing role of international and supranational institutions for creating opportunities for movements to mobilize. In this context, the approach is particularly well suited for analyzing opportunities and constraints connected with regulatory Europeanization. International and supranational bodies such as the European Union (EU) might through their (recommended or binding) policies and verdicts-as well as their formal or informal pressures against, or negotiations with, their member statescreate both opportunities and threats for movements (cf. Tarrow 2005). For instance, if the EU brings attention to specific political issues and recommends that its member states formulate policies to address these issues, the EU (its officials, representatives from other member states, etc.) can become an important ally for activists who are struggling against their own governments to give more attention to the issue in question. Organizations that are blocked at the national level might strategically make use of political opportunities at the European or international levels in order to obtain boomerang effects (Keck and Sikkink 1998; Beyers 2002). In alliance with 
international Non-Governmental Organizations (NGOs), those organizations might exploit international norms and organizations to generate pressure for compliance on public actors. International institutions can thus offer an authoritative venue for civil society actors to challenge state behavior (Keck and Sikkink 1998; Risse, Ropp, and Sikkink 1999).

Furthermore, it is important to acknowledge that political processes and actions take place not only in the formalized political system and its institutions but also elsewhere in the polity, such as in the bureaucracy, the judiciary, the media, industry, and among the many organizations and networks that make up civil society. This broader understanding of the political context makes it relevant to expand the political opportunity approach to include how actors use and are influenced by factors such as discourses produced by the mainstream or alternative media, which relates to processes referred to as discursive Europeanization in this book (see chapter 2). Social movements and interest organizations sometimes act as norm entrepreneurs by calling attention to issues or even creating new issues by naming, interpreting, and dramatizing them (Finnemore and Sikkink 1998). Snow and Benford (1988) identify three core framing tasks for social movements, and the degree to which these tasks are attended to will determine participant mobilization. The three tasks are

1. diagnostic framing for the identification of a problem and assignment of blame;

2. prognostic framing to suggest strategies and solutions to a problem; and

3. motivational framing that serves as a call to arms or a rationale for action.

If successful, the new frames resonate with a broader public understanding and are adopted as new ways of talking about and understanding various issues (Finnemore and Sikkink 1998). Through successful framing, organizations can thus attract attention and encourage action for change (Keck and Sikkink 1998).

Last but not least, even though many of the resources that social movement organizations need to mobilize might be without direct economic costs-in particular nonpaid activist labor-economic resources still have to be secured for activities such as meetings and issue publications. The economic resources can be secured through different channels such as governmental bodies, private foundations, private persons, or the market, such as pharmaceutical companies. In this respect the EU through different types of grants has opened new opportunities for many CSOs (Sánchez-Salgado 2010). The money transfer through financial Europeanization is, however, 
often in the form of short-term conditional grants that might give rise to a problematic level of dependency.

\section{The Political Breeding Ground for Patients' Rights, Drug Safety, and Consumer Reporting}

There has been a struggle over the patient's role in medical decision-making in many Western countries over the past few decades. The patients' rights movements of the 1960s questioned the authority of doctors and demanded informed consent and disclosure of medical information (Bayer et al. 2007). This development ignited an active citizenship more inclined to reflect critically on its relationship with government and other powerful bodies such as the medical profession and the pharmaceutical industry (Abraham and Lewis 2000). Physicians were now also accused of being responsible for pain and sickness induced by their treatments (Porter 1996). This course of events was partly an effect of the thalidomide tragedy of the late 1950s and early 1960s when it became clear that an antinausea drug being prescribed to pregnant women was causing serious birth defects (Carpenter 2010).

The thalidomide disaster underscored the necessity of systems to monitor the safety of medicines after they enter the market. As a consequence, government agencies were established to regulate the pharmaceutical industry in the interests of patients and public health (Davis and Abraham 2013). The World Health Organization (WHO) set up its international drug-monitoring program, and the Uppsala Monitoring Centre (UMC), an independent foundation, was established in 1978 to support the program. Through these initiatives, drug manufacturers were required by law to report to the appropriate authorities all adverse reactions to their drugs in a timely manner (Davis and Abraham 2013). Furthermore, doctors were asked to report all suspected adverse drug reactions they encounter in their clinical practice. However, it is well known that suspected adverse drug reactions are underreported, especially from health professionals (WHO 2002). The EU has also taken action. Within the EU suspected adverse drug reactions have since 2001 been reported to the European Medicines Agency and registered in the database EudraVigilance (Abraham and Lewis 2000).

An alternative way to increase reporting of adverse drug reactions is to allow citizens-in other words, the actual users of medicines-to report directly to the authorities; this is called consumer reporting or direct patient reporting. This is what KILEN, facing much opposition, struggled to implement in Sweden, among other things through their own collection of such statistics. Consumer reporting has been described as a public shaping of medical research and research politics, where the experience of the 
medicine users builds up a collective expertise of suspected adverse drug reactions (Wehling, Viehöver, and Koenen 2015). If the system works, the users/consumers might become coproducers in monitoring the postmarket safety of medicines through spontaneous reporting of adverse drug reactions to regulatory agencies (Borg et al. 201 1; Vilhelmsson 2015). A great leap forward was taken in 2010 when the EP voted in favor of new pharmacovigilance legislation to ensure greater patient safety and to improve public health, which was later cleared by the European Council. Since 2012 all EU countries are obliged to establish patient/consumer reporting within their spontaneous reporting systems as a part of the new European pharmacovigilance legislation (The European Parliament and the Council of the European Union 2010; EU Legislation on Pharmacovigilance: Regulation 2010). However, it is still uncertain how well the system works, and health consumer organizations have a key role to play in ensuring that the voice of the patient is indeed heard in the policy process.

Patients' rights vary in different countries depending on the political context and on prevailing cultural and social norms (Trägårdh 2007). The Scandinavian countries are characterized by strong political ties and institutionalized links between the popular mass movements and the welfare state, and by high trust in political institutions among the population. As in other Western countries the new social movements of the 1960s and the 1970s introduced new political conflicts and more contentious forms of activism in the Scandinavian countries (Ekman Jørgensen 2008). In Sweden the so called R-movement, gathering different client organizations, was actively engaged in social policy debates and required that clients be involved in and decide on issues affecting them (Meeuwisse 2008). However, compared to similar movements in other parts of Western Europe, the actions of many of the Scandinavian movements were less confrontational. Furthermore, in Sweden patient rights, born out of CSOs and popular movements, have traditionally been more focused on social rights than on individual rights (Trägårdh 1999, 2015). Many of the organizations have also become more or less interconnected with the state through funding and engagement in public investigations. It has been argued that the traditional corporatist model, developed mainly in relation to the class cleavage, in this way has been able to channel-or co-opt-new conflicts into mainstream politics (Jamison, Eyerman, and Cramer 1990). Consequently, it has been claimed that because of a strong belief in the state and the welfare system it has been harder for CSOs on a grassroots level to push for patient rights in Sweden compared to many other Western countries (Trägårdh 2015). This perhaps also partly explains the long absence of consumer/public interest group activity regarding the regulation of medicines in Sweden (Abraham and Lewis 2000). 
The responsibility for health and medical care is decentralized in Sweden and is shared by the central government, county councils, and municipalities. The regional level is especially important because the responsibility for providing health care has devolved to the politically elected county councils and, in some cases, municipal governments. But the patient's position in the Swedish health-care system is relatively weak, which has been confirmed by the quite recently established Swedish Agency for Health and Care Services Analysis (Vårdanalys), whose mission is "to strengthen the position of patients and users through analysing health care and social care services from the perspective of patients and citizens" (http://www.vardanalys.se/ Support/In-English/). Sweden now participates in the International Health Policy Survey where patients describe their experiences of health care. The results from a survey in 2014 (Swedish Agency for Health and Care Services Analysis 2014) do not indicate a fertile ground for patients' rights in Sweden. For instance, in comparison with ten other countries, health care in Sweden and Norway appears to be less patient oriented when it comes to discussing drugs and informing patients about possible side effects of medications and why they should take the medications. Health care in Sweden also falls short in its ability to involve patients in their care and in treating each patient as a unique individual. A new law to strengthen patients' opportunities to participate in their own care process was introduced in 2015, but it is not an explicit law of rights, and the position of the patient is thus somewhat unclear (Trägårdh 2015).

\section{Initial Success in Identifying a New Social Problem and Demonstrating the Need for Intervention}

The Swedish Association for Help and Assistance to Drug Users was established in 1965 and worked on issues concerning drug abuse and social exclusion. KILEN was officially opened in Stockholm in 1992 and was initiated by a handful people from the Swedish Association for Help and Assistance to Drug Users who specifically wanted to address the issues of drug dependency and consumer reporting of adverse drug reactions (Vilhelmsson 2014). They had already in the 1970s started to encounter patients who turned to them for help to break their addiction to tranquilizing, hypnotic, and analgesic medicines prescribed by physicians. The patients described adverse reactions to benzodiazepines and barbiturates, a problem that at this time in Sweden was almost unknown or unacknowledged both in the medical literature and by the national drug regulatory authority. As a consequence, a major part of the medical profession disregarded these patient experiences (UMC 2014). The initiators of KILEN began at an early stage 
to map the problem, to spread information, and to establish contacts with various authorities and stakeholders like the Swedish National Board of Health and Welfare (Socialstyrelsen), the Swedish Social Insurance Agency (Försäkringskassan), and the Stockholm County Council (Stockholms läns landsting). These contacts turned out to be vital in order to secure resources and legitimacy for future operations.

The initiators of KILEN aimed at becoming a center of excellence in developing consumer knowledge on drug and health issues and sought to work across professional and national borders. They based their work on direct contact with those afflicted by the problem of adverse drug effects and other treatment injuries by providing counseling, support, and assistance. The organization also held training courses, lectures, public hearings, and hearings in the Swedish Parliament for politicians; it published reports on adverse drug reactions and harm from drugs from a user perspective (KILEN 1997, 2002, 2004, 2005); and it spread information to the general public, politicians, and professional groups. KILEN also acted as lobbyists in order to influence policy regarding consumer reporting and adverse drug reactions.

These activities could be said to be part of a deliberate information policy, where the organization asserted its right to speak through reference to the deep knowledge of patients' experiences and living conditions. Claiming a close connection among insider knowledge, documentation, information, and advocacy is not an unusual strategy for interest groups and social movements (Jenness 1995). Margaret and Kathryn Sikkink $(1998,226)$ refer to an activist who described it as "the human rights methodology-promoting change by reporting facts." To succeed, such a strategy requires credibility, objectivity, and trustworthiness. Otherwise the organization risks being dismissed as unserious and misinformed.

However, it was particularly the support to patients that gave KILEN its initial legitimacy. According to a researcher at the UMC, KILEN filled a void in the social safety net:

KILEN took care of groups of patients who had no one else to turn to. That benzodiazepines could create side effects and dependency in the long run had started to be highlighted in the debate. It was prescribed in FASS [the Swedish Physicians' Desk Reference, which builds on the Summary of Product Characteristics from the pharmaceutical companies] that such drugs should only be given for a maximum of one week at a time, but this was not followed. These people were therefore no one's problem-no one had responsibility for them. They came to KILEN in desperation. (Interview researcher UMC)

In the beginning KILEN gained a certain echo among Swedish politicians and authorities and even received a fair amount of funding for the services 
and counseling it offered to patients. KILEN managed to raise public awareness on drug dependency and addiction and offered interventions to treat these new iatrogenic problems (UMC 2014; HAI 2005). During its first decade (1989-99), the organization received various amounts of funding from, among others, the Swedish National Board of Health and Welfare and the Stockholm County Council, and through targeted state subsidies disbursed to health authorities.

Several public figures from the political elite made speeches at the opening ceremony of KILEN, and the event was widely reported, including on Radio Sweden (Sveriges Radio). KILEN had identified a new social problem that was taken seriously and was met with sympathy from several influential politicians. At this point, KILEN clearly acted as a norm entrepreneur by calling attention to a new social problem and highlighting the issue of adverse drug reactions. They also succeeded in convincing several significant key persons with their diagnostic, prognostic, and motivational framing. In other words, they managed to get a hearing for their way to define, interpret, and point out what was needed in order to do something about the problem.

According to a politician of the Swedish Liberal Party, and also the director general of the Swedish National Board of Health and Welfare at the time, KILEN's contribution to patient reporting was also of great value: "When KILEN disappeared, the debate stalled. They were the driving force in this debate and when organizing the health care system. They have greatly contributed to providing the opportunity for patients to report side effects, earlier it was only allowed for doctors and dentists" (interview former director general of the Swedish National Board of Health and Welfare).

In the beginning KILEN had very good political contacts and their work was blessed by policymakers, both on a national and a regional level. Thus, the organization received governmental funding and in a way was protected from criticisms from the medical profession and regulatory authorities. These elite alignments were, however, unstable, and were dependent on the politicians in charge (they could for some time count on support from the Social Democratic Party, the Left Party, and the Green Party) and on short-term funding, often on a one-year basis following proposed budget claims. KILEN was sometimes strongly backed by individual politicians and senior officials in the health authorities, but some of these alliances proved to be vulnerable. This vulnerability became clear when KILEN diverted their main focus from treating patients with dependence symptoms and addiction associated with benzodiazepines and barbiturates and started to call attention to antidepressants. Suddenly some of their allies disappeared. 


\section{Into the Hornet's Nest: Antidepressants, a Medical Confrontation, and the Ghost of Scientology}

The new antidepressants, the selective serotonin-reuptake inhibitors (SSRIs), revolutionized the market in the 1980s. Together with the serotoninnorepinephrine reuptake inhibitor, these are often referred to as secondgeneration antidepressants (Healy 1997). These drugs quickly became very popular and were often seen as much safer than previous antidepressants. As long as KILEN worked with patients afflicted by drug dependency from tranquillizers and benzodiazepines, it met little resistance. Although some psychiatrists were critical of KILEN's campaigns, which they thought might cause unwarranted concern among patients, the organization had good relations with the medical profession and even collaborated with some physicians. However, when KILEN began to criticize the prescription of SSRIs and thus clearly became involved in health policy, the situation changed and they were faced with political and professional resistance. Difficulties also arose with financing. At one point the organization even had to temporarily file for bankruptcy. The most pronounced resistance came from a psychiatrist at Karolinska Institutet (a medical university in Stockholm) who in different ways tried to stop the funding of KILEN, for example by alerting funders and by participating in a live TV debate on the then newly released drug Prozac. He described the conflicting views in this way:

I expressed my worries, because I felt that they were missing the target. I also participated in a TV debate in 1995 when Prozac was released in Sweden. In addition to myself and Lena from KILEN, a priest and a representative of the Swedish Anxiety Society participated. I got into a fight with Lena. I was worried that patients would commit suicide if they stopped taking their medications. I think that the funding of KILEN temporarily ended after that. KILEN then wrote to the vice chancellor of the Karolinska Institutet and said it was unacademic behavior on my part, which they certainly were right about. But a professor of clinical pharmacology land a member of the Swedish Parliament for the Conservatives] managed to stop the government grants through The Social Affairs Committee. He used roughly the same arguments that I had, but it then also included KILEN's stance on antidepressants. (Interview psychiatrist at Karolinska Institutet)

It has been argued that patient organizations can gain acknowledgement only insofar as their demands are compatible with certain fundamental assumptions of medical science, medical authority, and the consumption of medical goods and services (Blume 2010). KILEN challenged mainstream medical science about what constitutes drug dependency and maintained 
that consumers themselves could determine adverse drug reactions. To substantiate their claims, KILEN published several reports on consumer experiences of drug dependency and reports from public hearings on drug damage, adverse events, and the increased prescribing of antidepressants (KILEN 1997, 2002, 2003, 2004). They also released a report on their website (KILEN 2005) comparing side effects and adverse drug reactions reported to their own database with those reported to the Medical Products Agency, the national medicines regulatory authority. In this way they wanted to show that consumers could distinguish between suspected adverse reactions and other symptoms just as well and sometimes even in a better way than reporting physicians.

KILEN was questioned on the grounds that its representatives lacked expertise in terms of medical and clinical training; some critics even claimed that they were followers of Scientology. (To discredit critics by labeling them as Scientologists seems to be a recurring approach to disagreements regarding mental illness and the use of psychotropic medication; see Whitaker 201 1.) Among other instances this suspicion of sectarianism was raised when KILEN organized a Nordic conference on patient reporting in 1995, in association with the Icelandic drug control authority (UMC 2014). According to one of KILEN's founders, opponents within the Swedish medical profession had tried to discredit them abroad by reaching out to their Icelandic colleagues with misinformation:

It turned out that the Icelandic Psychiatric Society had written a letter to the Icelandic physicians informing them that KILEN belonged to the Church of Scientology or perhaps Christian Science, they were a little unsure. The Icelanders did not know who we were, so it was obviously these Swedish psychiatrists that had informed the Icelandic Psychiatric Society that they had to watch out for us. But one of the doctors had worked as a district medical officer in Sweden for fifteen years and had many acquaintances here. He called around to all and soon realized that no, we were not Scientologists. (Interview founder of KILEN)

These accusations also hampered media relations, and the problem of representation (Epstein 2011) became an issue for KILEN. Due to the rumored association with Scientology, some media outlets did not take KILEN seriously. It has been argued that this type of guilt by association might taint the reputation of independent consumer organizations and question their role as the legitimate voice of patients and consumers (Jones 2008). Social movement organizations often rely on the media for mobilization of political support and legitimization (or validation) in the mainstream discourse, and the quality and nature of the media coverage strongly influence how they are perceived in the public eye (Gamson and Wolfsfeld 1993). To get the message out the movement or the organization has to successfully pinpoint 
what the problems are, what is causing them, and how they can best be solved. This requires not only contacts and knowledge of how the media works but also an understanding of how the message ought to be packaged and timed. KILEN received some media attention in the beginning, but it did not have an active media strategy and failed to create fruitful cooperation with the media. Some science and medical journalists never really understood who or what KILEN represented and what agenda they were advancing, and therefore held them at arm's length, which was expressed by a science journalist at one of Sweden's largest morning newspapers: "KILEN only had little coverage in the newspapers and was met with skepticism. I never got a clear picture of what the organization stood for. They were somewhat solitary and therefore had problems with credibility when they made their media actions. I didn't really understand why they were so engaged in criticizing psychotropic drugs, and I kept them at a distance" (interview Swedish science journalist).

\section{KILEN Goes Abroad in Search of Support and Allies}

The Swedish Medical Products Agency was not keen on establishing consumer reporting of suspected side effects and adverse drug reactions. One argument put forward was that patients were not able to distinguish between adverse reactions and symptoms of their disease. Another common claim was that consumer reports would create only background noise that somehow would distort the overall analysis (UMC 2014). At the time, consumer reports were often dismissed as being anecdotal or nonscientific (Herxheimer and Mintzes 2004). According to a pharmacovigilance expert who sympathized with KILEN, those arguments were not sustainable: "The argument that patients cannot determine and recognize the symptoms caused by drugs or underlying factors and distinguish between them is basically not true. Patients are not stupid. They recognize recurring symptoms when they take medications. It was often argued that the data they fill in are incomplete-that they don't know what's important. But several studies show that patient reports are no more poorly documented than others" (interview Swedish pharmacovigilance expert). After a while it became quite obvious to KILEN that there was a lack of political opportunities in the Swedish context because of the unfavorable political climate and the opposition from influential actors. They therefore established contacts and collaborations with key partners (individuals and organizations) abroad in order to reach an international arena and to continue their political advocacy. They thus tried to bypass the national level by compensating at the European level (as well as at the Nordic and international levels) in hopes 
of a boomerang effect. As argued by Keck and Sikkink (1998), domestic activist organizations increasingly seek international support or allies to try to bring pressure locally or nationally from the outside.

The EU, together with the WHO, played an important role in pushing KILEN's agenda for further acknowledgement. Consumer reporting had already attracted some attention at the European and international levels, where there was ongoing discussion about the problem of physicians underreporting adverse drug reactions (BEUC 2008; HAI 2005; van Grootheest, de Graaf, and de Jong-van den Berg 2003; WHO 2002, 2006). The European and international arenas offered KILEN several new important allies. Sweden's membership in the EU in 1995 also opened new opportunities for financial support for various projects.

Through its work, KILEN had become convinced that drug dependency was not an isolated Swedish phenomenon. They therefore arranged a number of Nordic conferences concerning drug dependency and patient reporting in the 1990s: Stockholm, Sweden 1994; Reykjavik, Iceland 1995; Mogenstrup, Denmark 1997; and Tromsø, Norway 1998. These conferences gathered control authorities, scientists, medical professionals, and patients. At the second Nordic conference in 1995, organized by KILEN and the Icelandic drug control authority, a joint statement was issued saying that patients' knowledge and experience of drug-related problems ought to be collected systematically and assessed equally valuable as adverse reaction reports from professionals. The conference gave the representatives for KILEN the task of trying to find the ways and means to achieve this goal.

KILEN applied for, and was granted, financial support by the European Commission (EC) to develop a Nordic database on consumer reports. ${ }^{1}$ This funding turned out to be pivotal: without this financial help KILEN would not have been able to establish the consumer database or engage in international networking. KILEN was later also funded by EU grants for an international EU project to collect and code consumer reports in Denmark and Moldavia (UMC 2006). Hence, KILEN clearly benefitted from financial Europeanization.

Through its international work KILEN managed to establish valuable contacts and found support among several authoritative international organizations and institutes around the world, including the $\mathrm{WHO}$, Health Action International (HAI), the Dag Hammarskjöld Foundation, the BEUC, the UMC, the group around the French journal Prescrire (UMC 2014), and several major national consumer organizations. This kind of networking gave KILEN an international reputation and leverage that they could also use in the Swedish context. The First International Conference on Consumer Reports on Medicines was held in Sigtuna in 2000 and was organized by KILEN in collaboration with many public and civil society 
actors. ${ }^{2}$ Participants included experts from the medical and pharmaceutical professions, drug regulatory authorities, consumers, and representatives of the WHO.

The conference in Sigtuna was later perceived as an important event in getting the idea of consumer reporting publicly known and more widely accepted (Herxheimer, Crombag, and Alves 2010). It resulted in the adoption of the consensus document "Consumer Reports on Medicines: Policy and Practice" (Finer et al. 2000), which was widely disseminated and had a significant impact. Another major step forward was when the representatives for KILEN received an invitation from the WHO to contribute to the twenty-fourth annual meeting of the WHO Programme for International Drug Monitoring held in New Zealand in 2001. According to a WHO program expert, KILEN was a key player that greatly influenced the views on consumer reporting:

The symposium in Sigtuna in 2000 was groundbreaking! They had invited experts from around the world who were the driving forces in the discussions. And this wasn't an isolated event. KILEN was among those who stood on the barricades for consumer reporting and participated very actively. They have for example been part of the WHO's annual pharmacovigilance program, and they presented about consumer reporting when representatives from numerous countries gathered in New Zealand in 2001. They have greatly influenced public opinion on patient reporting. Why should only doctors report? It became difficult to defend yourself against their arguments. (Interview WHO program expert)

One might here speak of discursive Europeanization, because KILEN seems to have been an important norm entrepreneur in changing the discourse of how patients' experiences were seen and acknowledged in Europe. By framing consumer reporting of adverse drug reactions as a civil rights issue and a question of solidarity, it was no longer only a matter for the medical establishment. KILEN was also recognized in the scientific literature as an important contributor of patient reporting (Blenkinsopp et al. 2007; van Geffen et al. 2007). Through their own database and by building collaborative networks among scientists, KILEN influenced the research agenda in identifying consumer reporting as a significant research gap or undone science. KILEN also to some extent managed to shape knowledge production on medical issues through adding data from consumers (cf. Wehling, Viehöver, and Koenen 2015).

KILEN's norm entrepreneurship can also be seen as part of a strategic action to exploit opportunity structures. In the international arena, KILEN could seek political alliances and lobby for policy changes in collaboration with other interest groups, such as with The Medicines in Europe Forum, the BEUC, and HAI. The Medicines in Europe Forum was launched in 
2002 to increase awareness among the public and policymakers of developments in pharmaceutical policy from a patient perspective. As a result of the activities of these umbrella organizations and patient associations, all EU member states were obliged in 2012 to implement the new pharmacovigilance legislation and thereby enable consumers to directly report adverse drug reactions to their drug regulatory agencies (EU Legislation on Pharmacovigilance: Regulation 2010). KILEN was one of the signatories to the Forum and thus also contributed to regulatory Europeanization (EPHA 2003). These events at the European level also clearly affected domestic affairs in Sweden. According to one of the founders of KILEN, nothing would have happened in Sweden without this external pressure: "I would go so far as to say that it is thanks to us that we have patient reporting at all, because when we started to pursue this matter it was seen as nonsense by the Medical Products Agency" (interview founder of KILEN).

\section{A Challenging Voice Falls Silent}

Despite success at European and international levels, KILEN continued to meet resistance at home. In order to survive economically KILEN was dependent on-and exploited-the shifting political power nationally, regionally, and locally. Because it worked on a controversial issue-in opposition to the pharmaceutical industry and powerful professional interests-it could never count on steadfast political support. This made the organization financially vulnerable and made it hard for it to make long-term plans. KILEN had a few allies among influential politicians and could cope as long as these defenders backed up their claims, but once they lost their political positions the organization was seriously weakened.

KILEN was unexpectedly forced into bankruptcy when a new center-right government took office in Sweden in 2006 and the Swedish Parliament in March 2007 decided not to allow continued government grants (Nihlén, Ericson, and Lindholm 2007; Westin 2007). According to the founders of KILEN, no explanation was ever given from the Ministry of Health and Social Affairs to justify the dismantling of KILEN as a consumer institute even though such demands were raised from several organizations and individuals, both nationally and internationally.

Since its establishment, KILEN met heavy domestic resistance from governmental agencies like the drug regulatory agency but also from many physicians and right-wing politicians. The Swedish Medical Association welcomed the shutdown of KILEN and strongly criticized the former Social Democratic government for having, after pressure from the Green Party and the Left Party, supported KILEN with state funding for several years. In the 
weekly Swedish health journal Dagens Medicin, the president of the Swedish Medical Association argued that KILEN had lobbied against the "best available psychiatric evidence" and had criticized psychotropic drugs in an unbalanced way, and also that KILEN's actions were based on emotions rather than on science (Helte 2006, 8). A Swedish pharmacovigilance expert also identified the emotional dimension of KILEN-noticeable especially in the first few years and exploited by opponents-as a problem: "They could become desperate and angry and go to the media with accusations-they were emotional. The authorities and government officials could therefore say that they were hysterical. Later, they learned and became more matterof-fact" (interview Swedish pharmacovigilance expert).

But the same person also pointed to a patronizing sentiment in Swedish culture that hampered the possibility for KILEN to get a hearing for its demands regarding patient reporting: "Sweden has refused to give in and was probably last in the world to introduce patient reporting; it was not until the EU directive that it was introduced. It's sad. There has been a patronizing attitude in Sweden-that this is something that only doctors understand, because the doctors are the ones who make diagnoses. An arrogant attitude. Today we know that this is wrong" (interview Swedish pharmacovigilance expert ). After the closing down of KILEN, its founders still had support from the Swedish Green Party that in several parliamentary bills (without success) maintained that it was a mistake to cut the state funding to the organization. In the bills it was argued that KILEN defended important consumer rights against the financial interests of pharmaceutical companies (Nihlén, Ericson, Lindholm 2007). One Green Party politician stated that KILEN was perceived as threatening the system, and that it eventually lost its political support because no politicians dared to openly oppose powerful interests: "To criticize such fundamental societal interests and authorities, primarily the National Board of Health and Welfare, but also the Medical Products Agency and the medical profession, is almost like committing suicide in Sweden today. My understanding is that very few politicians dared to talk about KILEN" (interview Swedish Green Party politician).

\section{Conclusion}

This case study suggests that the political opportunity structure in Sweden might be unfavorable for a civil society organization (CSO) that is challenging the medical establishment. There is a well-developed system for financial support for CSOs of various kinds, but our study shows that problems can occur if the organization has ambitions that can be perceived as political 
and threatening to powerful interests in society. KILEN managed to call attention to a new social problem, and as long as the organization mainly worked with direct services to individual patients afflicted by adverse drug effects, it enjoyed support from several influential politicians and senior officials in the health authorities. But when KILEN started to question the pharmaceutical industry and medical practices it was hit by political and professional resistance and withdrawn funds. The growth of professionalism in medicine in Sweden has gone hand in hand with the development of the state's prosperity in the welfare state, and there are close links between these institutions (Carlhed 2013). Medical doctors also enjoy high status and trust among the public and are rarely questioned. Hence, the patient's position in the Swedish health-care system is relatively weak. These factors in the Swedish political opportunity structure probably limited KILEN's ability to affect mainstream institutional politics and policy. The fact that the organization never managed to establish a good relationship with the media did not improve matters.

When the domestic political arena seemed more or less blocked, KILEN chose to build alliances with a number of authoritative key partners abroad and could also benefit from the greater interest in patients' rights and consumer reporting at the European and international policy levels. It was largely thanks to the financial support from the EC that KILEN could establish a consumer database and actively engage in international networking, which in turn eventually made it possible to influence the discourse and policy on drug safety at both the European and Swedish levels. The organization was forced to shut down in Sweden but had by then contributed to new EU legislation on pharmacovigilance that also affected the patients' position in Sweden. Thus, in the end KILEN's strategy of using political opportunities at European and international levels was fruitful.

Anna Meeuwisse is Professor of Social Work at Lund University, Sweden. One of her research areas concerns the changing roles of CSOs in the welfare state. She has been engaged in several research projects regarding civil society, advocacy, and transnational social movements in the areas of health and welfare.

Andreas Vilhelmsson is Public Health Researcher at the Faculty of Medicine, Lund University. A large part of his research focuses on patient organizations and especially patients' and consumers' experiences and understandings of their use of pharmaceutical treatment in relation to diagnosis and adverse drug reactions. Another research focus entails pharmaceutical regulation and how pharmaceutical companies interact on a policy level. 


\section{Notes}

1. KILEN also received some financial support from the Swedish National Board of Health and Welfare and the Swedish National Institute of Public Health (Nilsson 2002).

2. SIDA, the Swedish National Board of Health and Welfare, the Dag Hammarskjold Foundation, HAI, People's Health Assembly, UMC, the Swedish Consumers Association, and the Sigtuna Foundation.

\section{References}

Abraham, John, and Graham Lewis. 2000. Regulating Medicines in Europe: Competition, Expertise and Public Health. London, UK and New York, NY: Routledge.

Baggott, Rob, and Kathryn Jones. 2014. "The Voluntary Sector and Health Policy: The Role of National Level Health Consumer and Patients' Organisations in the UK." Social Science and Medicine 123: 202-9.

Bayer, Ronald, Lawrence Gostin, Bruce Jennings, and Bonnie Steinbock. 2007. "Introduction: Ethical theory and public health." In Public Health Ethics. Theory, Policy, and Practice, edited by Ronald Bayer, Lawrence Gostin, Bruce Jennings, and Bonnie Steinbock, 3-24. Oxford, UK: Oxford University Press.

BEUC. 2008. A Strong, Transparent and Proactive Pharmacovigilance System. BEUC Response to the Public Consultation on the Legislative Proposal on Pharmacovigilance. Brussels: European Consumer Organisation.

Beyers, Jan. 2002. "Gaining and Seeking Access: The European Adaptation of Domestic Interest Associations." European Journal of Political Research 41: $585-612$.

Blenkinsopp, Alison, Patricia Wilkie, M. Wang, and Philip A. Routledge. 2007. "Patient Reporting of Suspected Adverse Drug Reactions: A Review of Published Literature and International Experience." British Journal of Clinical Pharmacology 2, no. 63: $148-56$.

Blume, Stuart. 2010. The Artificial Ear. Cochlear Implants and the Culture of Deafness. New Brunswick, NJ: Rutgers University Press.

Borg, John-Joseph, George Aislaitner, Michal Pirozynski, and Stephen Mifsud. 2011. "Strengthening and Rationalizing Pharmacovigilance in the EU: Where Is Europe Heading to?" Drug Safety 34, no. 3: 187-97.

Carlhed, Carina. 2013. "The Rise of the Professional Field of Medicine in Sweden." Professions and Professionalism 3, no. 2. https://doi.org/10.7577/pp.562.

Carpenter, Daniel. 2010. Reputation and Power: Organizational image and pharmaceutical regulation at the FDA. Princeton, NJ: Princeton University Press.

Davis, Courtney, and John Abraham. 2013. Unhealthy Pharmaceutical Regulation: Innovation, Politics and Promissory Science. Basingstoke, UK: Palgrave Macmillan.

Ekman Jørgensen, Thomas. 2008. Transformation and Crises: The Left and the Nation in Denmark and Sweden, 1956-1980. London, UK: Berghahn Books.

Eisinger, Peter K. 1973. "The Conditions of Protest Behavior in American Cities." American Political Science Review 67: 11-28. 
EPHA. 2003. "Public Interest Group on Medicines Launched.” European Public Health Alliance. Retrieved 9 January 2014, from http://www.epha.org/a/509.

Epstein, Steven. 2011 . "Measuring Success: Scientific, Institutional, and Cultural Effects of Patient Advocacy." In Hoffman et al., Patients as Policy Actors, 257-77.

EU Legislation on Pharmacovigilance: Regulation. 2010. Official Journal of the European Union. Regulation 1235/2010. Retrieved 17 August 2018, from http://eur-lex. europa.eu/LexUriServ/LexUriServ.do?uri=OJ:L:2010:348:0001:0016:EN:PDF.

The European Parliament and the Council of the European Union. 2010. "Directive Amending, as Regards Pharmacovigilance, Directive 2001/83/EC on the Community Code Relating to Medicinal Products for Human Use." 2010/84/EU. Official Journal of the European Union. Retrieved 17 August 2018, from http://eur-lex.europa.eu/ LexUriServ/LexUriServ.do?uri=OJ:L:2010:348:0074:0099:EN:PDF.

Finer, David, Jan Albinson, Lena Westin, and Graham Dukes. 2000. "Consumer Reports on Medicines: Policy and Practice. Consensus Document Adopted at the First International Conference on CRM September 29-October 1, 2000, Sigtuna, Sweden." International Journal of Risk and Safety in Medicine 13, no. 2-3: 117-27.

Finnemore, Martha, and Kathryn Sikkink. 1998. "International Dynamics and Political Change." International Organization 52, no. 4: 887-917.

Gamson, William A., and Gadi Wolfsfeld. 1993. "Movements and Media as Interacting Systems." Annals of the American Academy of Political and Social Science 528: $114-25$.

HAI. 2005. Patients' Reporting of Adverse Drug Reactions. Outcomes of a seminar organized by Health Action International Europe, May 26.

Healy, David. 1997. The Antidepressant Era. Cambridge, MA: Harvard University Press.

Helte, Stefan. 2006. "Slut på statligt stöd till organisation för läkemedelsproblem." Dagens Medicin, 15 November: 8.

Herxheimer, Andrew, and Barbara Mintzes. 2004. "Antidepressants and Adverse Effects in Young Patients: Uncovering the Evidence." Canadian Medical Association Journal 170, no. 4: 487-89.

Herxheimer, Andrew, Rose Crombag, and Teresa Leonardo Alves. 2010. Direct Patient Reporting of Adverse Drug Reactions. A Twelve-Country Survey and Literature Review. Amsterdam, Netherlands: Health Action International Europe.

Hoffman, Beatrix, Nancy Tomes, Rachel Grob, and Mark Schlesinger, eds. 2011 Patients as Policy Actors. New Brunswick, NJ: Rutgers University Press.

Jamison, Andrew, Ron Eyerman, and Jacqueline Cramer. 1990. The Making of the New Environmental Consciousness: A Comparative Study of the Environmental Movements in Sweden, Denmark, and the Netherlands. Edinburgh, UK: Edinburgh University Press.

Jenness, Valerie. 1995. "Social Movement Growth, Domain Expansion, and Framing Processes: The Gay/Lesbian Movement and Violence Against Gays and Lesbians as a Social Problem." Social Problems 42, no. 1: 145-70.

Jones, Kathryn. 2008. "In Whose Interest? Relationships between Health Consumer Groups and the Pharmaceutical Industry in the UK." Sociology of Health and Illness. 30, no. 6: 929-43.

Keck, Margaret, and Kathryn Sikkink. 1998. "Transnational Advocacy Networks in the Movement Society." In The Social Movement Society, edited by David Meyer and Sidney Tarrow. Lanham, MD: Rowman and Littlefield.

KILEN. 1997. Bedövande erfarenheter. 550 år av läkemedelsberoende. De drabbades egna berättelser. Stockholm, Sweden: Consumer Association for Medicines and Health. 
2002. Läkemedelsskador och ansvar. Rapport från en konsumenthearing. Stockholm, Sweden: Consumer Association for Medicines and Health.

- 2003. Antidepressiva. Vad styr den ökade förskrivningen. Rapport från en konsumenthearing. Stockholm, Sweden: Consumer Association for Medicines and Health.

—. 2004. Att höra de ohörda. Rapport från en konsumenthearing om biverkningar och skador av läkemedel. Stockholm, Sweden: Consumer Association for Medicines and Health.

- 2005. Hur rapporterar dom? SSRI setralin (ZOLOFT). En jämförande studie mellan 327 konsumentrapporter (KR) på misstänkta biverkningar inrapporterade till KILEN och 437 läkarrapporter (LR) på misstänkta biverkningarinrapporterade till Läkemedelsverket. Stockholm, Sweden: Consumer Association for Medicines and Health.

Löfgren, Hans, Evelyne de Leeuw, and Michaek Leahy. 2011. Democratizing Health. Consumer Groups in the Policy Process. Cheltenham, UK: Edward Elgar.

McAdam, Doug. 1996. "Conceptual Origins, Current Problems, Future Direction." In Comparative Perspectives on Social Movements: Political Opportunities, Mobilizing Structures, and Cultural Framings, edited by Doug McAdam, John D. McCarthy, and Mayer N. Zald, 23-40. Cambridge, UK: Cambridge University Press.

Meeuwisse, Anna. 2008. "Organizational Innovation in the Swedish Welfare State." Critical Social Policy 28, no. 2: 187-210.

Meyer, David. S., and Debra C. Minkoff. 2004. “Conceptualizing Political Opportunity.” Social Forces 82, no. 4: 1457-92.

Nihlén, Thomas, Gunvor G. Ericson, and Jan Lindholm. 2007. "Motion 2007/08: So247. Kilens framtid." Retrieved 25 October 2016, from http://www.riksdagen.se/ sv/Dokument-Lagar/Forslag/Motioner/Kilens-framtid_GV02So247/?text=true.

Nilsson, Ingert. 2002. "Patientrapporterade biverkningar kan visa okända mönster." Läkemedelsvärlden. Retrieved 25 October 2016, from http://www.lakemedelsvarlden. se/nyheter/patientrapporterade-biverkningar-kan-visa-okända-mönster-1619.

Porter, Roy. 1996. "Introduction." In The Cambridge Illustrated History of Medicine, edited by Roy Porter, 6-16. Cambridge, UK: Cambridge University Press.

Risse, Thomas, Stephen Ropp, and Kathryn Sikkink. 1999. The Power of Human Rights. International Norms and Domestic Change. Cambridge, UK: Cambridge University Press.

Sánchez-Salgado, Rosa. 2010. "NGO Structural Adaptation to Funding Requirements and Prospects for Democracy: The Case of the European Union." Global Society 24, no. 4: 507-27.

Snow, David, and Robert Benford. 1988. "Ideology, Frame Resonance and Participant Mobilization." International Social Movement Research 1, no. 1: 197-217.

Swedish Agency for Health and Care Services Analysis. 2014. Vården ur patienternas pesrspektiv-jämförelser mellan Sverige och 10 andra länder. The Commonwealth Fund 2014 International Health Policy Survey. Report 2014-11. Stockholm, Sweden.

Tarrow, Sidney. 1988. "National Politics and Collective Action: Recent Theory and Research in Western Europe and the United States." Annual Review of Sociology 14: 421-40.

- 2005. The New Transnational Activism. Cambridge, UK: Cambridge University Press.

Tomes, Nancy, and Beatrix Hoffman. 2011. "Introduction." In Hoffman et al., Patients as Policy Actors, 1-16. 
Trägårdh, Lars. 1999. Patientmakt i Sverige, USA och Holland. Individuella kontra sociala rättigheter. Spri förmedlar, Hälso-och sjukvårdens utvecklingsinstitut. Stockholm, Sweden: IHE.

— . 2007. "The 'Civil Society' Debate in Sweden: The Welfare State Challenged." In State and Civil Society in Northern Europe: The Swedish Model Reconsidered, edited by Lars Trägårdh, 9-36. New York, NY: Berghahn Books.

—. 2015. "Patient- och funktionshinderrörelsens roll och förutsättningar: ett historiskt och komparativt perspektiv." I Myndigheten för vårdanalys, Sjukt engageraden kartläggning av patient- och funktionshinderrörelsen. Rapport 2015, no. 4: 35-44.

UMC. 2006. "News from around the World." Uppsala Reports 35, October. Uppsala, Sweden: Uppsala Monitoring Centre.

—. 2014. Uppsala Monitoring Centre: "Patient Reporting-from Controversy to Best Practice." Uppsala Reports 66, July. Uppsala, Sweden: Uppsala Monitoring Centre.

van Geffen, Erica C., S. W van der Wal, Rolf van Hulten, Mark de Groot, A. C. G. Toine Egberts, and Eibert R. Heerdink. 2007. "Evaluation of Patients' Experiences with Antidepressants Reported by Means of a Medicine Reporting System.” European Journal of Clinical Pharmacology 63: 1193-99.

van Grootheest, Kees, Linda de Graaf, and Lolkje de Jong-van den Berg. 2003. "Consumer Adverse Drug Reaction Reporting: A New Step in Pharmacovigilance?” Drug Safety 26, no. 4: 211-17.

Vilhelmsson, Andreas. 2014. A Pill for the Ill? Depression, Medicalization and Public Health. PhD diss., Department of Clinical Sciences. Lund, Sweden: Lund University.

- 2015. "Consumer Narratives in ADR Reporting: An Important Aspect of Public Health? Experiences from Reports to a Swedish Consumer Organization.” Frontiers in Public Health 3, no. 211.

Wehling, Peter, Willy Viehöver, and Sophia Koenen. 2015. The Public Shaping of Medical Research: Patient associations, health movements and biomedicine. London, UK: Routledge.

Westin, Lena. 2007. "Here Comes Some Information from KILEN about the New Situation." Stockholm, Sweden. Retrieved 2 February 2013, from the Kilen webpage (no longer exists).

Whitaker, Robert. 2011 . Anatomy of an Epidemic: Magic Bullets, Psychiatric Drug's, and the Astonishing Rise of Mental Illness in America. New York, NY: Broadway Books.

WHO. 2002. Safety of Medicines-A Guide to Detecting and Reporting of Adverse Drug Reactions. Why Health Professionals Need to Take Action. Geneva, Switzerland: World Health Organization.

—. 2006. The Safety of Medicines in Public Health Programmes: Pharmacovigilance an essential tool. Geneva, Switzerland: World Health Organization. 
Chapter 11

\title{
The Crisis of THE EUROPEAN UNION OPPORTUNITY OR GRAVEYARD FOR A EUROPEAN Civil SOCIETY?
}

\author{
Lars Trägårdh
}

As noted in the introduction to this book (Meeuwisse and Scaramuzzino), the degree to which the project of European integration has come so far that it is irreversible or, conversely, is tottering on the brink of collapse, is still an open question. In this chapter I will return to three of the questions raised directly or indirectly in the introductory chapter (see also chapters 1, 2, and 3). First: Is the current crisis of the European Union (EU) an opportunity for a deeper Europeanization of civil society? Or is the dominant response of European civil society rather tied to the forces that appear to be tearing the EU apart? Second: At a more theoretical level, how are we to think about the very notion of a European civil society in the absence of either a European state or a European nation or demos? As the introduction stresses, civil society can be understood as a public sphere where citizens meet to form a common nation, demos, and culture through discussions and debates. It can also be thought of as an institutional arrangement through which agents of the state connect in many ways-political, economic, legal-with citizens and representatives of organized civil society and its many interest organizations and social movements. On those terms, to what extent can we speak of a European civil society? And what kind of civil society is it in that case? Finally: What can the case of Sweden teach us in regard to the European state/civil society dynamic given that it is a society that is characterized both by a vibrant civil society and a strong welfare state, both of which 
are historically grounded in a social contract that ties together citizen and nation-state in a web of relations that have as much to do with identity and values-a public sphere-as with bureaucracy, institutions, and practices? Given Sweden's status as a quintessential nation-state, does the EU and the supposed Europeanization of Swedish civil society represent a threat or an opportunity? Does it even matter to the extent that it is meaningful to speak of Europeanization at a deeper level?

\section{The Crisis of 2016 and the Failure of European Civil Society}

The year 2016 has the potential of qualifying as one of those years that historians later will use as a marker for a moment of radical change, even discontinuity. Just as 1776, 1789, 1848, 1914, 1933, 1945, 1989, and 2001 have come to signify important shifts through revolutions, wars, the founding of the United Nations, the fall of the Berlin Wall, and the terrorist attack on New York and Washington, DC, 2016 has emerged as the year endowed with a similar historical gravitas. Whereas 1989 marked "the end of history" (Fukuyama 1992) and the conclusive victory of the democratic market societies over their socialist or communist contenders, 2016 became the year when nationalism defeated globalism, signaling "the end of the Western world as we know it" (Applebaum 2016). Instead of continuing with the victorious global economic system based on free trade and relatively open borders, founded in the post-World War II accords stretching from the Bretton Woods agreements and the Marshall Plan to the World Bank and the International Monetary Fund, we now face the return of protectionism and a stress on national sovereignty on all levels: social, cultural, economic, and political.

This turn away from globalist and postnational visions became brutally obvious during 2016 on both sides of the Atlantic. In the United States Donald Trump was elected as the new president on promises to build walls and impose protectionist economic policies under the banner of America First. In Europe, pro-European and globalist elites have been overwhelmed by political currents favoring a return of nation-statism. This found dramatic expression in the vote for Brexit in the UK during the summer of 2016, but these sentiments turned out to be widespread throughout the EU. Thus the elections in 2017 and 2018 gave ample proof of similar popular sentiment throughout the EU as voters in the Netherlands, France, Germany, Austria, and Italy proved disastrous to the mainstream center-right and center-left parties.

The crisis of the EU is also a failure of European civil society. At heart is the long-standing, much debated, and heavily researched democratic deficit 
that has separated the EU elites from the various peoples of the union. This deficit has been analyzed in institutional terms, and many attempts have been made to democratize the EU by introducing a balance between those institutions, such as the European Commission (EC), which express the top-down and confederal character of the union as a compact between independent nation-states on the one hand and those that embody the vision of an ever-closer union of the peoples of Europe on the other. Not least the establishment of the European Parliament (EP) is one such attempt; another is the European citizens' initiatives (ECI), which allows for an element of direct or at least participatory democracy, even though it is sometimes criticized for chiefly being a matter of discursive window dressing "without adding much in substance" (see Garcia 2015, 175; see also Greenwood 2015; Hedling, and Meeuwisse 2015).

But beyond or perhaps beneath the questions of constitutional and institutional arrangements lurks a far more difficult problem, namely the creation of a truly European demos, or nation. This conundrum touches on a challenge particular or at least particularly salient to the EU project: How does one embrace and promote diversity and difference and simultaneously ensure integration and union? Just as there is a certain ambivalence with respect to the institutional framework, leaning on the one hand toward confederalism and widening and on the other toward an ever-deeper unionization, there is a similar tension that applies to the politics of EU identity construction.

There have been many attempts to create or at least promote a common European identity. Recognizing that the creation of modern nation-states in Europe and elsewhere could serve as a model, a plethora of national symbols have been created that try to balance unity and diversity, from the EU flag and the adoption of Beethoven's "Ode to Joy" from his ninth symphony as the anthem of Europe, to an EU motto ("United in Diversity") and a "Europe Day" held on May 9 to celebrate peace and unity in Europe. Along with these there are European prizes and European Capitals of Culture and many other attempts at promoting awareness and pride in the EU. The creation of the common currency, the euro, must be understood in the same light. As many economists now argue, the euro is in fundamental ways incomplete as a common currency; its primary value has instead been symbolic, suggesting cultural unity as much as economic integration. Similarly, the issuing of passports in the name of both the EU and the member states denotes this duality of identity. One of the most significant attempts at Europeanization on the model of the nation-state is probably the various investments in research and higher education, such as the Erasmus program and the massive funding of research through the European Research Council, which have brought together students and scholars from across the EU. 
While these attempts at forging a common European identity along the model of the nation-states might have had some success, they have been limited if repeated Eurobarometer surveys are to be trusted. The reason becomes clear if we look more closely at how the projects of creating nationstates proceeded historically. As many scholars of nationalism have argued, a widespread sense of national belonging and community was relatively weak until the American and French revolutions ushered in the age of the nationstate. The elites often had a primary allegiance that was European and cosmopolitan, conversing as much in Latin and later in French and German as they did in the vernacular. The masses, on the other hand, retained local or regional identities and languages or dialects. In his influential book, Peasants into Frenchman, the historian Eugene Weber (1976) studied how France was transformed from a geographical concept into an "imagined community," to cite another seminal expert on nationalism, Benedict Anderson (1991). Weber observed that fewer than half of French subjects actually spoke French around 1850, yet by 1914 they felt sufficiently French to enthusiastically march to war in spite of a strong working-class movement across Europe that supposedly adhered to the International and its Marxist view of both state and nation as destined for the dustbin of history. How was this possible?

Weber provides a number of explanations involving both the state and civil society. In particular he stresses three developments: public schools, military conscription, and the creation of national media structures, which in turn linked to the standardization of a national language. Weber's findings are in line with those of a number of other historians who have studied similar developments in other European countries, involving what a major historian of German nationalism, George Mosse, calls the "nationalization of the masses" (Mosse 1974). The state uses its power to standardize and nationalize-a process that also entails integration and democratization. Thus, public schooling and conscription were key elements for both liberal nationalists and the working-class movement. In Sweden, for example, one slogan of the budding Social Democratic party was "One vote, one gun," suggesting the tight linkage between universal suffrage as a right and the duty to defend one's country. And the public school also built on the duality of rights and duties; it was both a compulsory duty and a universal right.

The third element, the creation of a common public sphere, a national media, a national language, and a national culture went hand in hand with the efforts to integrate at school and in the army. The connection between language and schooling is obvious; this was the way that children at an early age learned the national idiom. However, it was also a medium through which to assimilate the national narrative: stories, histories, literature, and culture that were presented as the common heritage. Furthermore, it 
entailed not only a simple, homogenous top-down process. Thanks to the rise of both national and local media, written in the national language, as well as a contentious civil society with a plethora of associations, it involved a more complex process of interaction between the state and civil society. On the one hand, a common language and shared conversation resulted; on the other hand, the emergence of a contentious public sphere and a myriad of often critical and oppositional associations created the foundation for a vibrant democratic political culture within the confines of the nation-state.

Thus, over time this was a development that had both an integrative side and a side that allowed for opposition and contestation. Together they resulted in the emergence of what we can call national democracy. With the introduction of universal suffrage on the one hand and a modern system of taxation on the other, this led to the elaboration of the kind of social contracts that we today live with in most Western democracies, even if they differ in important ways from country to country. In some ways, the social contracts are quite straightforward-at the one end citizens who vote, work, pay taxes and exert political influence through elections and their civil society organizations (CSOs), and at the other end the state that provides social rights such as education, health care, and pensions that are financed by taxes, a system administered by the state, sometimes in collaboration with CSOs. At the same time the politics of solidarity that we associate with the welfare state and the notion of social citizenship also depend on a sense of belonging and community.

In this way the modern nation-states were forged through a process whereby the state shaped civil society and civil society in turn exerted influence on state action. The result is a social contract that depends on both social trust among citizens and their confidence in common institutions, both public (state) and private (civil society). Without such trust, the legitimacy of the state is in doubt and civil society easily becomes a vehicle for division and polarization rather than the connective tissue between the state and its citizens. Indeed, there is a thin line between trust and distrust, as the crises of the 1840s and 1930s have shown, and this represents a potential fragility of the social contract that is possibly relevant to the current political crisis as we yet again witness the rise of populist nationalism rooted in distrust between the elites and the masses. Populist leaders from Napoleon III to Hitler, and Mussolini to le Pen and Trump, have repeatedly been able to generate popular support in civil society to challenge established political, cultural, and economic elites.

In this context it should be noted that while the state is the chief expression of the universal and national idea, many CSOs have historically been equally committed to the overall project of nationalization, often connected to political agendas emphasizing democratization. In the Swedish-and 
Nordic-case, this has been the case not least for the social movements (folkrörelserna) that were engaged in not just interest politics but also in a broader educational mission. Thus adult education ( folkbildning), including boarding schools for peasants and workers, the so-called folk high schools (folkhögskolor), often combined training in technical skills with classes aimed at enhancing knowledge of Swedish culture and history and providing training in civics (medborgarkunskap). However, the role of civil society is complex and cannot be reduced to being democratic or good in any simple sense. Thus the movements that today are supporting Brexit, Trump, le Pen, and other politicians are as much a part of civil society as those that support the EU, open borders, human rights, and postnational utopias.

\section{European Civil Society: Is It Possible without a European State?}

With this analysis of how the prenational territorial states of Europe nationalized their populations in the context of democratization, let us consider the EU again. As stated in the introductory chapter to this book, the proofs of successful European integration often include a common financial policy and currency, free movement of goods and people, and a common system of border control. However, on closer inspection the euro crisis in the wake of the financial crisis of 2008 has revealed that the euro is a case of an emperor without clothes, that the EU is lacking a truly integrated financial order. And the refugee crisis of 2015 in turn exposed the fragility of the border controls and the absence of a common policy with regard to migrants and refugees.

Beyond that, if we follow the logic described in the previous section regarding how stable nation-states were established in Europe (and beyond), the EU lacks other crucial aspects of both nation and state. If perhaps the most important components of a durable social contract involve a common language and common media, compulsory public schools and a conscription army, and a system of taxes that allow for social rights, these are also lacking in the EU. Add to this the lack of a fully realized common currency, the lack of a common army, and shaky control of the common borders, and we begin to get an idea of why the distance between citizens and the EU might be large indeed. And without the hard institutions of the state that in turn shape and structure civil society and mold that sense of community and belonging that is central to both demos and nation, it becomes difficult to imagine either how the democratic deficit can be shrunk or a stronger sense of European identity and culture can be achieved.

Of course, against this it can be argued that the EU is precisely not meant to be a state, but something else-a union of member states, the origin of 
which was more about establishing a common market and avoiding war among the European nation-states than about creating a social contract with deeper ambitions involving notions of citizenship, community, and belonging. Yet this is a line of argument that begs the questions currently dogging the EU, having embraced the idea of European citizenship and the social dimension, namely the democratic deficit and the lack of popular legitimacy among large portions of the European citizenry. The question that we need to ask is if it is possible to create a genuine public sphere and an institutionalized civil society in the absence of a state or a state-like structure.

If we consider theories of civil society, it becomes clear that the question of the relation between the state and civil society looms large. At the same time it is possible to identify several competing theoretical traditions that are all relevant for discussing the question of whether we can speak of a European civil society and, if so, in what way we can conceive of such an European civil society. One useful point of departure is the political theorist Jean Cohen's essay “Civil Society and Globalization: Rethinking the Categories" (Cohen 2007) in which she analyzes the postnational turn with respect to the concept of civil society. Noting that the discourse of civil society had gone global and become one of the "most widely utilized concepts by politicians, academics, and political activists around the world," Cohen also warns against the pitfalls of the "domestic analogy," which simply transposes "an unchanged analysis of parameters of a nationally oriented civil society to the global level." This would, Cohen argues, be a "serious mistake" (Cohen 2007, 37, 40, 48).

Instead, Cohen stresses, "The emergence of civil society goes hand in hand with the development of the modern territorial sovereign state" (Cohen 2007, 40). In particular, she argues, "it was the coupling of law and the state," constitutionalism, and representative government that made for the modern state's stable structure and enabled both the development of the market economy and a vibrant civil society in the context of national democracy (Cohen 2007, 40). Crucial to this order was a sense of a social contract that ultimately was built on trust, expressed concretely through a "gift exchange," as Marcel Mauss (1954) might have put it, among citizens in civil society via the shared institutions of the state according to the logic of duties (taxes) paid and (social) rights earned.

This understanding of the state/civil society nexus presupposed, as Cohen puts it, the sovereign state as a crucial "referent and target, tacitly assuming that civil society and the state are 'coterminous'” (Cohen 2007, 46-47). Crucially, this understanding was based on the idea of members in a bounded community who both acted as citizens, cowriting the law as members of the sovereign nation/people and obeying the rule of that law as subjects. The citizen's civic activity was thus directed at influencing political 
decisions made by the state, as well as at holding the state and its agents responsible and accountable by ensuring a degree of transparency and subjecting politicians to scrutiny through elections. But it went beyond mere dry constitutional arrangements and depended on a sense of national community. As Cohen writes, "Citizens construed as authors and addressees of the law, subject to the same jurisdiction and rules, are presumed to share a certain community of fate" (Cohen 2007, 46). And this sense of shared fate and identity also served as the basis for both welfare state solidarity and a politics of social justice. There is, Cohen continues, a "we" that insists that "our" representatives "make laws, policies and regulations that provide the social basis for meaningful citizenship, for social justice and social solidarity" (Cohen 2007, 46).

In practice, this has meant that although civil society at large, unlike the nation-state, is not formally defined by membership or national borders, it has nonetheless been focused historically on addressing the state through associations organized locally, regionally, and nationally, and only more peripherally supranationally. The same has been true for civil society understood as the public sphere-with public discourse and debate aiming at influencing collective public opinion and thus the formation of political will ultimately translated into legislation and policy in the context of the democratic, sovereign state. From this vantage point the notion of a global civil society is a dubious one for the simple reason that there is no global state, no global constitution to which such a global civil society would correspond and speak to. At best one can point to a variety of attempts at building a legal regime with global or at least regional reach through institutions such as, in the European context, the ECJ and, at the global level, the International Criminal Court, as well as the various human rights conventions connected to the UN.

While this incomplete and piecemeal juridification of international society is important, it still falls far short of becoming a global constitution. There is no equivalent of national political society and no counterpart to the accountable representative institutions of the nation-states, no effective transnational enforcement mechanisms that allow for making decisions that are both binding and subject to continual scrutiny though day-to-day politics, regular elections, and a critical public sphere. Furthermore, as I will return to in the discussion of the $\mathrm{EU}$, the tendency to lean on law in the absence of democratic political institutions carries with it its own dangers by making such supranational legal action vulnerable to charges of bypassing popular opinion and of being post- or antidemocratic.

The theory of civil society that Cohen subscribes to is rooted in the classic theory of Hegel for whom the notion of a civil society that is separate and decoupled from the state would have been largely unimaginable. However, Cohen departs from Hegel in that she embraces a conception, typical of 
most contemporary scholars thinking about civil society that separates out the market, i.e. for-profit economic actors, from civil society, which is cast as a nonprofit sector. For Hegel, by contrast, civil society was the social realm where individuals and groups sought to satisfy needs, fulfill desires, and protect interests. It included both what we today think of as the market and the associational life that in contemporary parlance has become synonymous with the more-narrow understanding of what constitutes civil society, with a focus on nonprofit organizations and Non-governmental organizations (NGOs).

Inspired by Adam Smith, Hegel envisioned civil society, including the market, as a legitimate, necessary, and ultimately positive force, enabling the pursuit of gain, pleasure, self-expression, and self-interest and leading at the aggregate, societal level to an increased wealth of the nation. At the same time, however, he also argued that the internal contradictions of civil society produced by this relentless pursuit of particular interests-atomistic individualism, inequality, poverty, and social disorder-could never be resolved by civil society itself. Only the state, Hegel argued, could promote and safeguard the general or universal interest of society as a whole, achieving a higher purpose of rationality that he described as the "unity and interpenetration of universality and individuality” (Hegel 1991, 276; Trägårdh 2010).

In other words, for Hegel civil society was not intrinsically good or civil, and he certainly did not view the state as inherently bad. Rather, he conceived of civil society and the state in more dynamic, relational, and evolutionary terms. From the individual's point of view, he suggested a movement from the inward-looking privacy of the family, through the forging of an intermediary social identity transcending private self-interest in the corporations and associations of civil society, to the universalist rationality embodied by the state. From a societal perspective, he stressed the institutions mediating and resolving conflict within civil society and connecting civil society to the state, rather than a reification of civil society in terms of opposing, overcoming, or transcending the state.

However, in the contemporary world, the Hegelian idea of civil society has largely lost out to a very different notion of civil society, one that informs most ideas of global civil society and, for that matter, most national conversations that invoke the concept of civil society. In this reading, the central organizing trope is what another political theorist, Margaret Somers, calls the "meta narrative of Anglo-American citizenship theory" in which the state is always seen as hovering "on the brink of being a source of tyranny" (Somers 1995, 259). In this alternative conception of civil society, civil society is seen as prior to and autonomous from the state rather than being the product of certain historical developments of the modern state that created the conditions that allowed the development of civil society. 
This theory of civil society has left a heavy mark on current narratives on civil society, especially global civil society but also at the national level and in the context of the EU. Indeed, the modern use of the term originated in Eastern Europe during the years leading up to the collapse of communist rule. Because the state was viewed as oppressive and corrupt, the oppositional movements like Solidarity in Poland were invested with great hope and moral weight. As a consequence, ordinary politics associated with political parties, politicians, and the institutions of the state was viewed with suspicion and a sense of utter disillusionment. This disgust with ordinary politics led to a certain overinvestment in the promise of civil society. In the words of Havel, it became a dream of an antipolitical politics built on the supposed humanity of the people as opposed to the professional propaganda of career politicians. He envisioned a politics from below, that he termed a "politics of people, not of the apparatus, [a] politics growing from the heart not from a thesis" (Havel 1988, 398). This sense of utopian euphoria also attended the 2011 uprisings in North Africa and the Middle East that derived their energy from the same enduring fantasy with its links to the French Revolution, and beyond that to heroic, if mostly futile, revolts on the part of long-suffering slaves and serfs around the world.

Here we see a common theme that unites thinkers on the left and on the right. On the left there was Marx, who imagined an international civil society as the end point of a dialectical process, including bourgeois revolution and proletarian dictatorship, when the state would wither away and deliver man into anarchic, universal freedom. On the right there was an equally utopian antistatist sentiment among radical liberals. Thus libertarian thinkers like Hayek dreamt about a spontaneous order where the state has shrunk into insignificance, setting society and man free.

While such extreme antistatism belongs to the fringes of the political spectrum, what is more common is the decoupling of state and civil society that is typical in the world of global or international civil society. Thus we have witnessed the growth of so-called NGOs that have become important actors with respect to the post-1989 project of spreading free-market democracy across the globe. As Jens Stilhoff Sörensen (2010) has argued, the ascendency of civil society as a fashionable concept in the development and aid sector was intimately linked to the paradigmatic shift from a state-centered approach to the development of a neoliberal focus on the market. With the loss of faith in state-to-state aid and the rise of a broader neoliberal trend dating back to the Thatcher-Reagan era, the Washington consensus brought with it a new focus on civil society NGOs as both the vehicle and target for aid-a semi-utopian faith in the market and civil society was joined to a deep skepticism of the Keynesian state-centered approach. 
Another variant of this poststatist conception of civil society is the notion of civil society that is central to John Keane's idea of monitory democracy, which imagines a new stage in the development of democracy that he calls "post-representative" democracy (Keane 2007). He imagines an "epochal transformation [when] the world of actually existing democracy experiences an historic sea-change, one that is taking us away from the assembly-based and representative democracy of past times towards a form of democracy with entirely different contours and dynamics" (22).

However, in the first decade of the twenty-first century, this faith in the magic of civil society has been declining, not least in the wake of the 9/11 attacks and the rise of the war on terror. To some extent the state is making a comeback, though this is a return that is largely restricted to the securityrelated functions of the state and does not include Nordic-style ambitions to promote state-guaranteed social security. Furthermore, it becomes increasingly clear that to speak of a global civil society, as Keane does, in the absence of a global state is problematic at best. Insofar as civil society is in fact constituted by and inseparable from the modern state-even if it occasionally spawns and fosters a critique of that state-it is clear that the Hegelian emphasis on the relations between the state and civil society, and the ties that bind them together, is as relevant as ever. Civil society seems plainly incapable of replacing the state. Instead of pitting one against the other-a rhetorical and tactical ploy of Eastern European dissidents and of American neoliberals alike-might it perhaps be more fruitful to focus on the ways in which the interplay of state and civil society results in a productive mode of governance?

From a civil society point of view, the EU occupies a kind of middle ground between the institutional solidity of the nation-state and the fluidity of the global (dis)order. On the one hand, there are the various mechanisms through which the EU constitutes a very concrete opportunity structureas discussed in several of the chapters of this book-whereby money and other resources are channeled to local CSOs through EU organs such as the European Social Fund (ESF) or via the European Research Council to scholars throughout Europe (see, e.g., chapters 3 and 4 by Scaramuzzino and Wennerhag; and chapter 6 by Di Placido and Scaramuzzino in this book). On the other hand, some of these initiatives can be seen as an EU equivalent of global foreign aid policies, whereby richer countries in the northwest of the EU distribute aid to the poorer ones in the east and south, sometimes via NGOs that operate similarly to the many projects carried out by Western NGOs in Africa or Asia. As projects that are poorly rooted in the local political economy, they are prone to produce resentment as much as gratitude, as is the case for most forms of charity.

A third type of civil society activity in Europe is the one that Mary Kaldor and Sabine Selchow has called the "The 'Bubbling Up' of Subterranean 
Politics in Europe" (2013), a regional equivalent of the Occupy movement with its antiestablishment, antistatist, and anarchic proclivities. Many of these movements belong to the broader phenomenon of movements that challenge the primacy of the nation-states, speaking in the language of human rights and no borders. But while they can be thought of as postnational, that does not make them European. Rather, the ire is as much directed at the EU as Fortress Europe as it is against the individual nation-states. The concern of such movements is in a sense more focused on the negative consequences of borders while being informed by a cosmopolitan utopianism, than it is focused on feeding a vision of the EU as a step toward a global order.

However, there is another way in which the EU provides an opportunity structure that is truly postnational in the way that Jean Cohen also discusses, namely that the EU, while failing in the mission to create a European demos or nation, has succeeded in establishing a supranational legal order. As New York Times journalist Roger Cohen noted in an article from 2000, the EU has in one regard represented a fundamental challenge to national sovereignty. However, he argued, this emerging European identity is based not on the adoption of a common culture in the sense of a common language, literature, or history, nor in the republican and statist sense as organized around mass political parties, the ritual of voting, conscription, or an oath of allegiance. Rather, Cohen claimed, this "new sense of European citizenship [was founded on the] pre-eminence of European law over national legislation" (Cohen 2000).

This aspect of Europeanization is in some ways also a matter of Americanization in that it involves the type of juridification of politics that has for a long time been a hallmark of US political culture (Trägårdh and Delli Carpini 2004). While the ECJ initially was focused on rather mundane and technical issues related to trade and fishing quotas, it has over time evolved into a place where Europeans go to uphold their rights, rights that at times are claimed against national states on the basis of a developing EU charter of individual rights and antidiscrimination laws. In this way the EU has changed the political playing field in a novel way in Europe, providing CSOs representing minorities such as the disabled, which have been discriminated against at the national level, with a new opportunity to fight back (Lawson and Gooding 2005). This particular aspect of the Europeanization of civil society has not been in focus in this book but would be worthy of further consideration (see also Meeuwisse and Vilhelmsson, chapter 10).

At the same time, European integration and the challenges to national sovereignty do not just stimulate the growth of a European civil society that sees the EU primarily as an opportunity structure, be it in economic terms as a source of money or in a juridical sense as an avenue to pursue justice in a court of law. Equally important, it is now evident, are those CSOs that 
are formed and empowered to resist European integration and to reassert national sovereignty. Again, this takes many forms, from the politics of right-wing and left-wing populism that is directed against migration and open borders or against the harsh austerity programs rooted in neoliberal economic policies, to a reaction against the many ways in which the EU as a community of law enables the ECJ to overrule decisions made in the national parliaments. During the Brexit campaign, the "Leave" proponents appealed to many of these arguments, stressing control of territory, borders, and the national legal space. From a Swedish point of view, Refugees Welcome and the anti-immigrant party, the Sweden Democrats, represent the poles of such tendencies toward the Europeanization of civil society. But such a statement must be tempered by the fact that even if Refugees Welcome and other CSOs fighting for migrants' rights might be critical of the nation-states for their closed borders and harsh treatment of refugees, this does not mean that they necessarily see the EU as a more progressive force (Barker 2015; Sager, Holgersson, and Öberg 2016). Likewise, while the Sweden Democrats might enter into tactical alliances with like-minded parties elsewhere in Europe, their ultimate goal is to strengthen, not weaken, national sovereignty.

\section{Sweden and the EU: Welfare State Nationalism and the Specter of Europe}

Empirically speaking, Sweden and the other Nordic countries have perhaps come the closest to constituting a democratic, neo-Hegelian political order (Trägårdh 2010; Trägårdh and Witoszek 2013). Characterized by a democratic corporatist system whose hallmark is precisely the routinized institutions that connect state and civil society in a peculiar form of governance, these societies exhibit both a large, vital civil society providing political input and social voice from a particularized society and an equally strong state given the task to represent and safeguard national community and universal social welfare.

In this way Sweden is also set apart from most of the rest of the EU. As noted in the introduction to this book, there exists a mismatch between the Swedish social contract, including the composition and function of civil society, and that of the EU at large. I will return to this question but let us first note that skepticism toward the EU is not specific to Sweden. Indeed, many Europeans view the EU and the move toward an ever-closer union with mixed feelings. While security concerns and the peace argument continue to play an important role, it is evident that with the fading memory of World War II and the collapse of the Soviet Union, the process of economic 
and political integration has increasingly come to be complicated by concerns over national identity. To some extent the emergence of neonationalism is an expression of the increasing split between the elites, who tend to be persuaded by integrationist arguments and seduced by the promise of increased economic growth, and the masses, who are both less European in their outlook and more prone to feel threatened by unemployment thought to be linked to globalization (see also Hedling and Meeuwisse, chapter 5). Thus the political climate has pushed to the fore the latent conflict between the EU project and the survival of the nation (Trägårdh 2002).

It is in this perspective that a deeper understanding of how historically rooted conceptions of national identity inform the politics of Europe becomes crucial. In fact, the extent to which Europeans feel such bouts of anxiety has varied quite dramatically from country to country, ranging from the relative Euro-enthusiasm in the heartland countries like France, Germany, Italy, and the Benelux, via legendary British insularity and intransigence within the union, to Swiss and Norwegian refusals to even join the EU. From this perspective, Sweden is a reluctant latecomer to Europe, joining the EU only in 1995 and then with only a slim majority of the population voting "yes" after a heated and divisive debate. In fact, a considerable part of the population continues to view the EU with mixed feelings and are as likely to express apprehension over the specter of Europe as to express confidence in the promise of Europe. In the end, what convinced that slight minority of Swedes to vote yes to join the EU were economic arguments made against the backdrop of one of the most profound economic crises in Sweden since the Depression. Symptomatically, even then Sweden was one of the few members to vote against the adoption of the euro as a common currency (Trägårdh 2002).

How do we explain this EU-skeptical attitude on the part of the Swedes who otherwise would seem to be well poised to take advantage of the benefits afforded by membership, not least given their long-standing commitment to free trade and their dependence on large, export-oriented companies?

To understand this, one must grasp the ways in which European integration in the form of adapting to the EU poses a deep threat to the way in which many Swedes have come to understand the proper relationship between state, society, nation, and people. That is, Swedish national identity has come to be tightly linked to the welfare state, understood not simply as a set of institutions but as the realization of the People's Home (Folkhemmet), the central organizing slogan of the Social Democrats who dominated Swedish politics from 1933 until 1990 and who still remain the largest party in the Swedish Parliament.

The extraordinary and lasting potency of this concept derives from the seamless way in which the two concepts of the people-those of demos and 
ethnos-have been fused into one coherent whole. That is, it is not simply that in Sweden the democratic-Jacobin notion of the people has won out over the ethnic-cultural reading associated with, most infamously, the German experience. Rather, the Swedish concepts of people, popular/ populist/democratic, and people's home (folk, folklighet, and folkhem) are all part and parcel of a national narrative that has cast the Swedes as intrinsically democratic and freedom-loving, as having democracy in the blood. Thus, since to be a Swedish nationalist meant perforce that one embraced democratic values, it was possible in the 1930s for the Social Democrats to successfully harness the power of national feeling, to become national socialists, and to fight off the challenge from domestic wanna-be Nazis (Trägårdh 1990; Trägårdh 2002).

Furthermore, and just as importantly, the Swedish Model, as it came to be known, was characterized by an extreme form of statism, built on a social contract between a strong and good state on the one hand and the emancipated and autonomous individual on the other. Through the institutions of the state, the individual, so it was thought, was liberated from those institutions of civil society that harbored patriarchal and hierarchical values and practices-the traditional family, the conservative churches, and the upper-class charity organizations. The inequalities and dependencies associated with these institutions were to be replaced by an egalitarian social order.

In this scheme, the state and the people were conceived of as intrinsically linked; the people's home was a state that served as the homely domain of national community, the context in which the ideal of solidarity could be joined to that of equality. At the same time, this Swedish ideology, with its dual emphasis on social equality and individual autonomy, was understood to be distinctly modern and highly efficient; the welfare of the welfare state implied not just solidarity and equality but also prosperity and progress.

This does not mean that civil society was only a force of reaction in this particular imaginary. Rather, Swedish civil society was conceived to have two components that were locked in battle. Positioned against the reactionary civil society associated with charity and philanthropy were the social movements that represented the working class. Their political agenda was to replace the need for philanthropy with taxes and the necessity of charity with social rights.

From this point of view, the left-wing supporters of the nation-statist Swedish welfare state could only imagine Europe to the south of Denmark as a backward bastion of neofeudalism, patriarchy, hierarchy, disorder, corruption, and inequality. During the heated debates in the early 1990s over whether Sweden should join the EU, continental notions like subsidiarity and civil society were perceived as insidious, neoliberal, or papist ideas, 
fundamentally antithetical to the founding principles of the welfare state. Sweden was continually cast in the trope of democracy, equality, and solidarity, while Europe was pictured, especially by the Social Democrats and the Left at large, in terms of the so-called four K's: konservatism, kapitalism, katolicism, and kolonialism. That is, Europe was cast as the conceptual opposite of Sweden. It was the realm of untamed capitalism, it suffered from the legacy of colonialism, its social policies were informed by backward notions rooted in Catholic social thought, and it was politically dominated not by Social Democratic parties but by conservatives of different shades (Ekström, Myrdal, and Pålsson 1962; Trägårdh 2002).

Conversely, the political parties to the right have tended to see in Europe a possibility to accomplish through the back door what they have consistently failed to achieve at the national level-the dismantling of the oppressive welfare state and the revitalization of what they see as an atrophied civil society. Liberals came to see the EU as a project promoting the freedom of the market from state regulation and the freedom of the individual from the narrow confines of Swedish egalitarianism. Social conservatives and Christian Democrats, on the other hand, imagined the restoration of the natural social structures of civil society that they believed had been undermined by the unholy alliance between big government and big business.

Beneath the political rhetoric of the debate over EU membership there were, however, very real differences between Sweden and most of the EU with respect to the relationship between the state and civil society and the composition and role played by CSOs in Sweden. Comparatively, Swedish civil society was both larger and different, and the ties between the state and civil society were also far more developed and intricate. On the one hand, the dominant organizational form was the democratic membership association-not charities, philanthropies, nonprofit organizations, or faithbased organizations, as was the case in many other parts of the EU. On the other hand, the links between civil society and the state were intimate and numerous, not least through the system of governmental commissions that allowed for continual input from civil society into the political process leading to laws and policies (Trägårdh 2007a). Furthermore, Swedish CSOs have tended historically to primarily have a political or voice function rather than being a provider of welfare services (schools, health care, elderly care). The moral and political logic that characterizes Swedish civil society is thus similar to the one that infuses the social contract as a whole, stressing individual autonomy and social equality and being antithetical to unequal power relations, be it charity, patriarchal family relations, or hierarchical and undemocratic forms of organization (Trägårdh 2010). This has translated into the primacy of the alliance between citizen and state, what I have termed statist individualism, and a civil society that is more invested in the 
input side of the social contract and the political process (voice) than in the provision of welfare as nonprofit organizations (service).

In this perspective it is crucial to note how different the Swedish statecivil society nexus looks in comparison to that of the United States and many other European countries south of Denmark. The antistatism so prevalent in the United States but also the stress on charities and nonprofit organizations in continental Europe is often linked to a romantic and rather unrealistic conception of what civil society in fact can do to combat poverty, inequality, and social injustice. While charities can alleviate some suffering, they can do little to address systemically the underlying structures of inequality and injustice. Indeed it might be argued that charity and private philanthropy tend to further entrench and even legitimize such injustice. By contrast, tax-financed social investments typical of the Swedish welfare state has a universal reach, aiming in principle if not always in fact to reach all citizens while taking the form of rights, rather than alms.

\section{Conclusions}

While the (over)heated rhetoric that dominated the debates from the 1960s until the early 1990s has since given way to a far more balanced and much less emotional discourse on Europe and the EU, fundamental continuities prevail. In many ways, Sweden has been much like Great Britain in that the decision to join the EU was driven far more by the cold logic of economic necessity than by any passionate dreams of a united Europe. And, like England, Sweden imagined itself to be more global than European, more committed to free trade than to Fortress Europe. Swedish internationalism grew after World War II, but it was fueled more by enthusiasm for the UN and by solidarity with the developing world than by the narrower project of the EU. As the historian Mikael af Malmborg summarized the debate over European integration between 1945 and 1959: "Norden, the world, and nothing in between" (Malmborg 1994, 32), an attitude that would remain salient well into the debates over EU membership in the 1990s.

From a civil society perspective, this continued Swedish focus on the nation-state has translated into a rather instrumental attitude toward the EU. There has been recognition on the part of local governments and local CSOs that the EU, through for example the ESF, has come to constitute an opportunity structure to be exploited. To do so effectively, there has also been a willingness to adopt continental concepts such as social economy in order to discursively match the requirements for EU funding (see Di Placido and Scaramuzzino, chapter 6; and Levander, chapter 7). However, beyond this almost mechanical level there are few signs of deeper Europeanization, 
something that several of the chapters of this book tend to confirm (see Scaramuzzino and Wennerhag, chapter 4). As suggested above, one area in which a Europeanization of civil society might be occurring is the relation to the ECJ insofar as Swedish CSOs and individual citizens use courts to pursue individual rights and fight discrimination, using the European courts to trump Swedish law. This is a topic that warrants further study.

The relationship between Sweden and the EU began as a kind of shotgun wedding when Sweden was in a deep economic crisis and in need of a gallant knight in economic armor. Since then the relationship has developed into a cool but durable marriage of convenience, short on passion but long on mutual economic benefits. Like Germany, Sweden has been a winner in the era of globalization and in this scheme the EU has been an important piece in the puzzle. But in terms of the politics of solidarity and the interplay between state and civil society, Sweden as a whole and its civil society in particular remains profoundly national. There might no longer be the same intense anti-European rhetoric as before, but nor is there much of a sense of an ever-closer union with the rest of the EU. This is as true for Swedish civil society as it is for Sweden more generally.

Lars Trägårdh received his $\mathrm{PhD}$ in history from UC Berkeley and is currently Professor of History and Civil Society Studies at Ersta Sköndal Bräcke University College in Stockholm. He has published widely on Swedish history; some of his publications concerning civil society include State and Civil Society in Northern Europe (Berghahn Books 2007) and Civil Society in the Age of Monitory Democracy (Berghahn Books 2013).

\section{References}

Anderson, Benedict. 1991. Imagined Communities: Reflections on the Origin and Spread of Nationalism. London, UK: Verso.

Applebaum, Anne. 2016. "Is This the End of the West as We Know It?" Washington Post, March 4.

Barker, Vanessa. 2015. "Border Protests: The Role of Civil Society in Transforming Border Control." In Rethinking Border Control for a Globalizing World: A Preferred Future, edited by Leanne Weber, 133-5133-51. Abingdon, UK: Routledge.

Cohen, Jean. 2007. "Civil Society and Globalization: Rethinking the Categories." In Trägårdh, State and Civil Society in Northern Europe, 37-66.

Cohen, Roger. 2000. "A European Identity: Nation-State Losing Ground.” New York Times, January 14.

Ekström, Tord., Gunnar Myrdal, and Roland Pålsson. 1962. Vi och Västeuropa. Stockholm, Sweden: Raben and Sjögren. 
Havel, Vaclav. 1988. “Anti-Political Politics.” In Civil Society and the State, edited by John Keane, 381-98. London, UK: Verso.

Hegel, G. W. Friedrich. 1991. "Elements of the Philosophy of Right in Wood.” Elements of the Philosophy of Right. Cambridge, UK: Cambridge University Press.

Fukuyama, Francis. 1992. The End of History and the Last Man. London, UK: Hamish Hamilton.

Garcia, Bouza, Louis. 2015. "The Effect of the European Citizens' Initiative in the Field of European Civil Society." In Johansson and Kalm, EU Civil Society, 175-92.

Greenwood, Justin. 2015. "Civil Dialogue and the Citixens' Initiative: Accounting for Collaboration an Competition Using the Advocacy Coalition Framework and the Strategic Action Field." In Johansson and Kalm, EU Civil Society, 193-209.

Hedling, Elsa and Anna Meeuwisse. 2015. "The European Citizens' Initiative Stage: A Snapshop of their Cast and their Acts". In Johansson and Kalm, EU Civil Society, 210-28.

Johansson, Håkan., and Sara. Kalm. 2015. EU Civil Society: Patterns of Cooperation, Competition and Conflict. Basingstoke, UK: Palgrave Macmillan.

Kaldor, Mart, and Sabine Selchow. 2013. “'The 'Bubbling Up' of Subterranean Politics in Europe.” Journal of Civil Society 9, no. 1.

Keane, John. 2013. "Civil Society in the Era of Monitory Democracy." In Trägårdh, Witoszek, and Taylor, Civil Society in the Age of Monitory Democracy, 22-51.

Lawson, Anna, and Caroline Gooding. 2005. Disability Rights in Europe: From Theory to Practice. London, UK.: Hart.

Malmborg, Mikael af. 1994. Sverige och den västeuropeiska integrationen 1945-1959. Lund: Lund University Press.

Mosse, George. 1974. The Nationalization of the Masses: Political symbolism and mass movements in Germany from the Napoleonic wars through the Third Reich. New York, NY: Fertig.

Sager, Maja, Helena Holgersson, and Klara Öberg, eds. 2016. Irreguljär migration i Sverige. Göteborg, Sweden: Daidalos.

Somers, Margaret. 1995. "Narrating and Naturalizing Civil Society and Citizenship Theory: The Place of Political Culture and the Public Sphere." Sociological Theory 13, no. 3 .

Stilhoff Sörensen, J. 2010. "Introduction: Reinventing Development for the TwentyFirst Century?” In Challenging the Aid Paradigm, edited by Jens Stilhoff Sörensen, 1-22. Basingstoke, UK: Palgrave Macmillan.

Trägårdh, Lars. 1990. "Varieties of Volkish Ideologies." In Language and the Construction of Class Identities, edited by Bo Stråth and Carl Holmberg, 25-54. Gothenburg, Sweden: Gothenburg University Press.

—. 2002. "Welfare State Nationalism: Sweden and the Specter of 'Europe." In European Integration and National Identity: The Challenge of the Nordic States, edited by Lars Hansen and Ole Wæver, 130-81. London and New York: Routledge.

- 2007a. "Democratic Governance and the Creation of Social Capital in Sweden: The Discreet Charm of Governmental Commissions." In Trägårdh, State and Civil Society in Northern Europe, 254-70.

—, ed. 2007b. State and Civil Society in Northern Europe: The Swedish Model Reconsidered. New York, NY: Berghahn Books.

- 2010. "Rethinking the Nordic welfare state through a neo-Hegelian theory of state and civil society." Journal of Political Ideologies 15, no. 3: 227-39. 
Trägårdh, Lars, and Michael Delli Carpini. 2004. "The Juridification of Politics in the United States and Europe: Historical Roots, Contemporary Debates and Future Prospects." In After National Democracy: Rights, Law and Power in America and the New Europe, edited by Lars Trägårdh, 41-78. Oxford, UK: Hart.

Trägårdh, Lars, and Nina Witoszek. 2013. "Introduction." In Trägårdh, Witoszek, and Taylor, Civil Society in the Age of Monitory Democracy, 1-21.

Trägårdh, Lars, Nina Witoszek, and Bron Taylor, eds. 2013. Civil Society in the Age of Monitory Democracy. New York, NY: Berghahn Books.

Weber, Eugen. 1976. Peasants into Frenchmen: The Modernization of Rural France, 18701914. Stanford, CA: Stanford University Press. 


\section{SECTION IV}

This open access library edition is supported by the University of Lund. Not for resale. 
This open access library edition is supported by the University of Lund. Not for resale. 


\title{
CONCLUDING REMARKS
}

\author{
Anna Meeuwisse and Roberto Scaramuzzino
}

This book is a product of the joint efforts of a research team linked to the research program Beyond the Welfare State-Europeanization of Swedish Civil Society Organizations (EUROCIV) financed by the Swedish Research Council. It is based on the first systematic study of the Europeanization of civil society organizations (CSOs) in Sweden, and it draws on both survey data and case studies spanning a range of different types of organizations operating at various levels. In this final chapter we want to briefly sum up the findings in relation to the overall themes outlined in the introductory chapter.

Our point of departure is an understanding of Europeanization as a two-way process in which the European Union (EU) influences domestic actors, but where domestic actors also make use of the EU. This process might be enabling as well as constraining for CSOs, producing opportunities on the one hand but leading to increased regulation on the other (introduction and chapter 1 ). We also suggest a multidimensional approach to Europeanization as summarized in the typology presented in chapter 1 . This typology draws attention to both direct forms of Europeanization such as regulatory, financial, and organizational Europeanization and indirect forms such as participatory, discursive, and identity Europeanization. Each empirical chapter addresses one or more of these forms of Europeanization, and different theoretical perspectives are used in the book in order to grasp both institutional pressure and organizational strategies and the interplay 
among them. For example, theories of resource mobilization have proven fruitful for investigating financial Europeanization (chapter 6), while theories of neo-institutionalism and isomorphic pressures have been helpful when analyzing discursive Europeanization (chapter 7).

One of the main results from our studies is that Europeanization only seems to concern a minority of Swedish CSOs, and this holds true irrespective of whether we consider activities such as influencing policy (regulatory Europeanization), applying for funding (financial Europeanization), or being a member of a European umbrella organization (organizational Europeanization). In other words, relatively few organizations actively pursue activities at the European level. According to many Swedish CSOs, the impact of the EU on the domestic level and on civil society also seems to be relatively weak, which suggests a low level of Europeanization. Considering that the majority of the organizations in our survey were local organizations, these results are hardly surprising. For a local association in a small municipality in Sweden, Brussels is likely to be perceived as both geographically far away and difficult to access, but also as politically irrelevant. Our results in fact reflect the centrality of the grassroots level for most Swedish CSOs and the difficulties these organizations might encounter in connecting to other levels of government (chapters 3, 4, and 5).

Studying organizations within the welfare policy area has yielded several valuable insights into the Europeanization of Swedish civil society. This is a policy area in which the EU has a weak mandate, hence such a study provides insight into not only why CSOs might Europeanize, but also why they sometimes might not. A lack of resources and expertise is often highlighted as explanations in research on Europeanization, but we can conclude that the perceived relevance of the EU for the organization's work is indeed at least as important (chapter 4).

Skepticism of the EU might, however, also stem from a perceived ideological clash between values and norms that are ascribed to EU institutions and those that the organizations stand for. For example, this is the case in the gender policy area where Swedish organizations might perceive the supra-national level (both public institutions and other CSOs on this level) as being less responsive to issues of gender equality and gender-based violence (chapters 8 and 9). Our study clearly illustrates how Swedish CSOs within the social welfare area in various ways try to defend the Swedish social policy model from outside pressure. But we also find organizations that are critical of different aspects of the Swedish model and that use the opportunities to organize and participate at the European and international levels to gain support for their criticism (chapters 9 and 10).

Many of the results presented in this volume point to similarities across countries and are comparable with results from studies from other national 
contexts. Some of the findings, however, seem to be quite specific for Sweden and in particular in regard to the strong role of the state in enabling and constraining civil society actors' strategies at the European level. For example, our analyses demonstrate that public authorities and political parties play an intermediary role in CSOs' attempts to influence public policy (chapter 3). The domestic public funding system also plays an important role in creating the financial stability that is required to handle EU funding. Furthermore, it is often Swedish public authorities that guarantee the stability and continuation of EU-financed projects (chapter 4). Swedish organizations are thus often dependent on domestic public support in order to access the EU level, but they might be less dependent on EU support for their survival than organizations in other countries.

A closer analysis of the resource mobilization of Swedish CSOs uncovers the exclusionary and exclusive dimensions of EU funding and shows that only economically stable and resource-strong organizations with administrative capacity can apply for, be granted, and handle EU funding. This pattern is corroborated by our identification of a group of domestic professionalized CSOs with access to public funding and decision-making that were more Europeanized than the rest. EU opportunities are thus in reality mainly accessible to resource strong, politically embedded organizations buttressing the view of EU integration as an elite project (chapter 5). A similar pattern is found within the gender equality policy area, but where weak forms of participatory Europeanization not only seem to be due to lack of resources or embeddedness, but also as a consequence of ideological concerns (chapter 8).

The political opportunity structure approach that informs many of the chapters highlights how the EU activities of Swedish CSOs are often shaped by their relationship with domestic public authorities within a system of interest representation and funding that enjoys strong support. The habitually close and trustworthy relations between state and civil society seem on the one hand to create the precondition for Swedish organizations to Europeanize. On the other hand, however, the prospects offered by the EU institutions seem to be more of a complement than an alternative to opportunities at the domestic level. However, organizations that are at odds with the Swedish system might use the supra-national level to put pressure on domestic authorities and established norms. Yet it is also clear that the Swedish state is prepared to, and is capable of, countering such strategies when these are perceived as threatening domestic interests, norms, and values. This is illustrated, for example, by the prolonged conflict between representatives of the pharmaceutical industry and the medical profession on the one hand and a health consumer organization on the other (chapter 10). Such struggles testify about the gate-keeping function of the Swedish welfare state. 
Our typology of Europeanization has allowed us to disentangle different dimensions implied in the concept of Europeanization, and this has proven fruitful for focusing the analysis presented here. However, while these different forms of Europeanization are more or less distinct at a theoretical level, our studies show that they are intertwined at the empirical level. For instance, results from our survey data show that there is no perceived tradeoff between strategies such as influencing policy, applying for funding, or being a member of an umbrella organization at the European level, which suggests that regulatory, financial, and organizational Europeanization tend to reinforce each other (chapter 4).

The case study on the Swedish reception of the social entrepreneurship paradigm institutionalized at the EU level (chapter 7) also shows that discourses entering the domestic field through EU integration facilitate the introduction of new policies by policy entrepreneurs, suggesting a strong link between regulatory and discursive Europeanization. The social entrepreneurship model is closely associated with neoliberal tendencies in EU policy legitimizing nonstate service providers in the social welfare domain, which does not match the general understanding of civil society in Sweden as a complement rather than an alternative to public welfare service provision.

Furthermore, organizational Europeanization might impact on civil society actors' identity through socialization processes. It is clear that activities at the supranational level might not only imply cooperation, but also conflicts between organizations with different norms and values. This is, for instance, evident in the policy area of sex work/prostitution, which is characterized by different and often contrasting framings of prostitution as sex, as work, or as gender-based violence. These conflicts appear most clearly when organizations become members of umbrella organizations and have to negotiate their identity with members from other national contexts (chapter 9). Identity conflicts based on ideologies are handled through different strategies, including trying to change or adapt to the dominant frames. Several of our case studies highlight such inter-organizational and inter-sectoral relations of both cooperation and conflict among civil society actors at the EU level.

The role that domestic embeddedness plays in the Europeanization of civil society is a debated issue, and previous studies point in partly opposite directions (see chapter 5). Access to domestic political authorities is, according to some scholars, crucial for successful engagement at the EU level, while other research indicates the opposite, that it is those that are marginalized at the national level that actively seek support at the EU level in order to compensate for their lack of influence at the domestic level. This volume provides support for both of these propositions. Our data at the aggregated level suggest that the $\mathrm{EU}$ is an exclusive arena reserved for resource-strong 
and embedded Swedish CSOs, thus reproducing existing hierarchies in civil society. At the same time, we find cases where support from EU institutions can strengthen actors that are challenging domestic power structures and established relations in the field of CSOs.

Anna Meeuwisse is Professor of Social Work at Lund University, Sweden. One of her research areas concerns the changing roles of CSOs in the welfare state. She has been engaged in several research projects regarding civil society, advocacy and transnational social movements in the health- and welfare area.

Roberto Scaramuzzino is Researcher at Lund University, Sweden. His research interests include changes in the welfare and integration systems and the role of CSOs in different countries. He has been engaged in comparative studies of mobilization in the migration and prostitution policy fields in Sweden and Italy, and at the EU level. He is currently working in a research program on civil society elites in Europe. 


\section{THE SURVEY STUdY}

\section{Roberto Scaramuzzino and Magnus Wennerhag}

The quantitative studies in this volume (chapters 3 and 4) are based on a large quantitative dataset resulting from a national survey that received responses from 2,791 Swedish civil society organizations (CSOs). The survey was carried out from November 2012 to March 2013 as part of the research research program: Beyond the Welfare State-Europeanization of Swedish Civil Society Organizations (EUROCIV).

The sample for the survey was based on the categories used by Statistics Sweden (SCB) in their register of Swedish organizations (Företagsregistret). The focus of the research program was CSOs engaged in welfare issues and interest representation. To cover this type of organization, the sample included associations (ideella föreningar) and religious congregations (registrerade trossamfund).

In order to get access to economic resources and other benefits granted by Swedish legislation, most CSOs register with the authorities as belonging to one of these categories. An association is the most common organizational form for Swedish CSOs (Wijkström and Einarsson 2006), and it provides a legally simplified framework for certain activities (e.g., possibilities to make limited economic transactions without being taxed).

The sample was further specified by including only CSOs that were categorized by Statistics Sweden as associations involved in social service and care, associations involved in interest representation, and religious 
congregations. These three categories were chosen in accordance with the overall aims of our research project, namely to provide a comprehensive analysis of how processes of Europeanization affect Swedish CSOs working with welfare policy and how they strategically make use of the European Union (EU) as a new political opportunity structure. ${ }^{1}$ By selecting these categories, we thus excluded some other kinds of organizations, such as sports and recreational and leisure associations. Among the "social service and care" associations, one finds, for instance, the Red Cross, Save the Children, Alcoholics Anonymous, women's shelters, crime-victim advocacy organizations, and disability organizations. Among the "interest representation" associations, one finds trade unions, professional and employers' organizations, political parties, immigrants' and pensioners' organizations, and cultural associations. Religious congregations were chosen because they are often involved in social welfare activities on behalf of families living in poverty, undocumented migrants, and other marginalized groups. Among these registered CSOs, one finds local or regional chapters of national federations as well as the national federations themselves (most Swedish CSOs register their local, regional, and national bodies as separate associational entities). One also finds quite small CSOs that do not belong to any federation.

When gathering our sample from this population, we furthermore chose to include both organizations/congregations that were classified by Statistics Sweden as economically "active" and the ones classified as "nonactive." This classification is made only on the basis of an organization's/ congregation's recent contacts with the Swedish Tax Agency. To be active, an organization has to meet at least one of the following criteria (according to data that Statistics Sweden get from the Swedish Tax Agency): have had employed staff, have paid wages, have sent other information to the Swedish Tax Agency, have had incomes, or have had assets of a higher value than 10 million SEK (approximately 1 million euros) and/or income from interest higher than 0.5 million SEK. In our study, we primarily wanted to study CSOs that had ongoing activities in some sense, and not just CSOs that had contacts with the Swedish Tax Agency. We therefore believed it to be relevant for our purposes to include both active and nonactive CSOs and only later on to exclude the organizations/congregations that according to themselves were totally inactive. To be able to do this, we included a question asking whether the organization had had any activities during the previous year.

In line with our expectations, our later analysis of the data showed that the differences between the associations labeled active by Statistics Sweden and the ones labeled nonactive were quite small in terms of actual activities (and regarding response rate). Of those being labeled as nonactive by Statistics Sweden, only 5 percent said they did not have any activities during 
the previous year; the corresponding figure for associations labeled "active" was 1 percent (Scaramuzzino and Wennerhag 2013). The 76 cases of CSOs that had not had any activities during the previous year were excluded from our further analysis.

Through these choices, the total population of organizations forming the basis for our study's sample consisted of 80,015 associations, which can be said to represent approximately 40 percent of formally organized Swedish civil society. According to Statistics Sweden's calculations, Swedish civil society includes about 217,000 formal organizations (Statistics Sweden 2010).

Because the actual numbers of organizations differed significantly between the three categories constituting our population, we decided to make a stratified sample so as not to end up with insufficient numbers of cases for the smaller categories. In each of the three categories we furthermore sampled a lower percentage of the organizations being labeled nonactive. Table A.l shows the exact sizes of each sample and how each sample corresponded to each of the categories percentagewise. Having used this stratified sampling procedure, we gave the CSO categories different weights in the analysis so that the presented results of univariate and bivariate analyses would be the same as if we had analyzed a nonstratified sample.

Table A.1. Sample Size, the Sample's Relation to the Total Population, and the Response Rate

\begin{tabular}{lcccr}
\hline & $\begin{array}{c}\text { Social service } \\
\text { and care }\end{array}$ & $\begin{array}{c}\text { Interest } \\
\text { representation }\end{array}$ & $\begin{array}{c}\text { Religious } \\
\text { congregations }\end{array}$ & Total (N) \\
\hline Sample size & 878 & 1,765 & 516 & 3,159 \\
Active CSOs (N) & 910 & 1,812 & 299 & 3,021 \\
Nonactive CSOs (N) & 1,788 & 3,577 & 815 & 6,180 \\
$\begin{array}{l}\text { Total (N) } \\
\text { Sample's relation to total }\end{array}$ & & & & \\
$\quad$ population & $100 \%$ & $12 \%$ & $50 \%$ & \\
$\begin{array}{l}\text { Percentage of total active } \\
\text { population }\end{array}$ & $50 \%$ & $3 \%$ & $25 \%$ & \\
$\begin{array}{l}\text { Percentage of total } \\
\quad \text { nonactive population }\end{array}$ & & & & \\
Response rate & $58 \%$ & $54 \%$ & $49 \%$ & $54 \%$ \\
$\begin{array}{l}\text { Active CSOs } \\
\text { Nonactive CSOs }\end{array}$ & $52 \%$ & $47 \%$ & $42 \%$ & $48 \%$ \\
Total (\%) & $55 \%$ & $51 \%$ & $46 \%$ & $51 \%$ \\
Total (N) & 852 & 1,567 & 372 & 2,791 \\
Source: EUROCIV survey. & & & & \\
\hline
\end{tabular}


The survey questionnaire was sent by mail with a prepaid return envelope to the contact persons or office addresses of 6,180 Swedish CSOs randomly chosen from the total population. After three reminders and a short nonresponse survey by mail, 2,791 questionnaires were returned. The final response rate was 51.3 percent after a number of CSOs had been excluded because they had ceased to exist or changed their associational form, or due to faulty postal addresses. As can be seen in table A.1, the response rates of the three categories of CSOs varied between 46 percent and 55 percent, and the response rate of active CSOs was 54 percent while it was 48 percent for nonactive CSOs. Overall, we deemed these differences in response rates to be too small to take into account in the subsequent analysis. For more detailed information about the sampling procedure, see Scaramuzzino and Wennerhag (2013).

The three categories of CSOs from Statistics Sweden described above were used to create a sample in accordance with the overall aims of our research project. For chapters 3 and 4 in this book, however, we grouped the cases of our dataset according to theory-driven typologies that more clearly corresponded to this book's aims. Thus, in our analysis we compared ten categories of CSOs (as discussed in chapter 3 ) on the basis of survey data from 1,786 CSOs. To focus our analysis on the types of CSOs that are working with issues clearly related to the social welfare area, we excluded the 889 cases in our original sample that did not meet this criterion.

The typology for CSO types used in chapters 3 and 4 was inspired by a typology used in previous studies about associational life in Sweden (e.g., Vogel et al. 2003). In order to group the CSOs of our sample into this typology, we assessed the organization's focus of activity on the basis of their name, information given in answers to the survey about the organization's main goals and activities, and information found on the Internet (mostly the organizations' own websites). In appendix B we give an overview of the 10 types of CSOs we identified through this procedure, and the most common specific organizations within each type.

The CSOs were furthermore manually classified with regards to their organizational level, such as the geographical level where they mainly carry out their activities and have their members. Through this procedure, the CSOs were classified as local, regional, national, or supranational. For CSOs being part of national federations (and similar hierarchical organizational bodies), this was easy to determine because they are often named according to the municipality in which they are based. When it comes to CSOs not being named this way, we used information found on the Internet to be able to do this classification. 


\section{Note}

1. More precisely, the specific categories included (according to Statistics Sweden's standard Swedish Standard Industrial Classification [SNI] 2007) were SNI 86 ("Hälso- och sjukvård"-"Human health activities"), SNI 87 ("Vård och omsorg med boende"-"Residential care activities"), SNI 88 ("Öppna sociala insatser"-"Social work activities without accommodation"), and SNI 94 ("Intressebevakning; religiös verksamhet"-"Activities of membership organisations"). In our analysis, the organizations having the codes SNI 86, 87, and 88 are called "Social service and care," and organizations with code SNI 94 are called "Interest representation." For more information about the SNI 2007 standard, see https://www.scb.se/en/documentation/ classifications-and-standards/swedish-standard-industrial-classification-sni/.

\section{References}

Scaramuzzino, Roberto, and Magnus Wennerhag. 2013. "Influencing Politics, Politicians and Bureaucrats: Explaining Differences between Swedish CSOs' Strategies to Promote Political and Social Change." Paper presented at the ECPR General Conference, Bordeaux, France, September 4-7.

Statistics Sweden. 2007. "SNI Swedish Standard Industrial Classification 2007." Retrieved from http://www.sni2007.scb.se/_pdf/080131 snisorteradeng2007.pdf.

—. 2010. Det civila samhället 2010: Ett regeringsuppdrag med undersökningar från Statistiska centralbyrån. Örebro, Sweden: Statistiska centralbyrån.

Vogel, Joachim, Erik Amnå, Ingrid Munck, and Lars Häll. 2003. Föreningslivet $i$ Sverige: Välfärd, socialt kapital, demokratiskola. Stockholm, Sweden: Statistiska centralbyrån. Wijkström, Filip, and Torbjörn Einarsson. 2006. Från nationalstat till näringsliv? Det civila samhällets organisationsliv i förändring. Stockholm, Sweden: European Civil Society Press. 
Appendix B

\title{
Civil SOCIETY ORganizations TyPES
}

\author{
Roberto Scaramuzzino and Magnus Wennerhag
}

Disability organizations: 167 cases. Of these, 5 organizations each have 10 to 12 cases (Hörselskadades riksförbund, FUB, Hjärt- och Lungsjukas riksförbund, Reumatikerförbundet, and RSMH), and 20 organizations each have 2 to 9 cases. The remaining 37 cases are organizations with only 1 case each.

Temperance and drug users' organizations: 72 cases. Of these, 22 are chapters of IOGT-NTO (the Swedish branch of the International Organisation of Good Templars), 22 are associations belonging to Länkrörelsen (which are organizations inspired by Alcoholics Anonymous), and 5 are chapters of Motorförarnas Helnykterhetsförbund (part of the temperance movement). The remaining 23 cases are organizations with 1 to 3 cases each.

Trade unions: 110 cases. Of these, 48 are unions belonging to TCO (Swedish Confederation of Professional Employees), 46 are blue-collar trade unions belonging to LO (Swedish Trade Union Confederation), 12 are unions belonging to Saco (Swedish Confederation of Professional Associations), and 4 are other trade unions.

Victim support organizations: 56 cases.

Women's organizations: 90 cases. Of these, 76 are women's shelter associations. The remaining 14 cases are organizations with 1 or 2 cases each.

Other interest organizations for social groups: 148 cases. Of these, 79 are pensioners' organizations, 36 are immigrant organizations, 10 are parents' 
organizations, 6 are lesbian, gay, bisexual, and transgender (LGBT) organizations, and 6 are students' unions. The remaining 11 cases are organizations with only 1 case each.

Humanitarian organizations: 450 cases. Of these, 266 are chapters of Red Cross Sweden, 69 are chapters of Save the Children Sweden, 27 are chapters of Hela Människan (a Christian charitable organization), 15 are chapters of Majblommans riksförbund (a children's charity organization), 11 are chapters of S:t Lukas förbund (a Christian charitable organization), and 9 are chapters of Lions (the Swedish branch of Lions Clubs International). The remaining 53 cases are from various charity organizations (e.g., Rotary, Stadsmissionen, Verdandi, and Emmaus).

Social service organizations: 78 cases. Of these, 34 provide social care services, 22 provide child-care services, and 22 provide other types of social services.

Religious associations and congregations: 533 cases. Of these, 337 are groups and congregations of the (Lutheran) Church of Sweden, 140 are various Free Church congregations and associations (i.e., nonconformist Lutheran churches), 21 are other Christian churches (Catholic and Orthodox), 17 are various ecumenical organizations, and 18 are other churches and religious associations.

Political parties: 82 cases. These include chapters and youth and women's associations for the main political parties: the Centre Party (8 cases), the Christian Democrats (3 cases), the Green Party ( 8 cases), the Left Party (20 cases), the Liberals ( 4 cases), the Moderate Party ( 10 cases), the Social Democrats (25 cases), the Sweden Democrats (2 cases), and other parties (2 cases). 
Appendix C

\title{
SURVEY QUESTION WORDINGS AND RESPONSE AlTERNATIVES
}

\author{
Roberto Scaramuzzino and Magnus Wennerhag
}

\begin{tabular}{lll} 
Variable & Survey question & Response alternatives \\
\hline $\begin{array}{l}\text { Generation of } \\
\text { CSOs }\end{array}$ & $\begin{array}{l}\text { 2. In what year was your organization } \\
\text { founded in Sweden? }\end{array}$ & - \\
$\begin{array}{l}\text { Number of } \\
\text { members }\end{array}$ & $\begin{array}{l}\text { 7. How many members does your } \\
\text { organization have? [Individuals; } \\
\text { Organizations] }\end{array}$ & \\
$\begin{array}{l}\text { Elected } \\
\text { representatives }\end{array}$ & $\begin{array}{l}\text { 8. How many elected representatives does } \\
\text { Employed staff }\end{array}$ & - \\
& $\begin{array}{l}\text { 9. How many full-time employed staff does } \\
\text { your organization have? }\end{array}$ & - \\
Volunteers & $\begin{array}{l}\text { 10. Does your organization have volunteers } \\
\text { connected to your organization (i.e., } \\
\text { persons that are neither members nor }\end{array}$ & Yes; No; If yes, how \\
employed)? & \\
$\begin{array}{ll}\text { 12. How often does your organization have } \\
\text { on different } \\
\text { geographical } \\
\text { levels }\end{array}$ & $\begin{array}{l}\text { activities on the following geographical } \\
\text { levels? [Local or municipal level; National } \\
\text { level; Nordic level; European level; }\end{array}$ & $\begin{array}{l}\text { Often; Sometimes; } \\
\text { International level] }\end{array}$
\end{tabular}


Variable

Membership

in networks

and federations

at different

geographical

levels

\section{Importance of \\ different sources of funding}

Service

provision on

behalf of public

organizations

Application for

EU funding

Perceived results of receiving EU funding
Response alternatives

13. Which of the following types of

Yes; No; Don't know networks, federations, or umbrella

organizations is your organization a direct member of? [Local networks or umbrella organizations; National networks or federations; Nordic networks or federations; Networks or federations at EU or European level; Other international networks or umbrella organizations]

14. How important are the following sources of funding for the budget of your organization? [Members' fees; Sales of goods and services; Economic support from the local municipalities; Economic support from the state; Economic support from EU bodies (e.g., European Social Fund or European Regional Development Fund); Companies (sponsoring, gifts, etc.); Private persons (gifts, donations)]

\section{To what extent do the following} statements describe your organization in an accurate way? [We are an organization that provides service on behalf of the local municipalities, the region/county, or the state.]

\section{How often does your organization do} some of the following? [Apply for economic funding from the EU; Is granted the EU funding that we have applied for; Employs a lot of resources (knowledge, time and staff) when we apply for EU funding; Adjust our activities to increase our chances to get funding.]

\section{If your organization receives, or has} earlier received, EU funding, to what extent do you agree with the following statements? [EU funding has made it possible for us to initiate new projects and activities that we otherwise wouldn't have been able to start; To administer EU funding demands a lot of resources (knowledge, time, staff); The accountancy rules for EU funding have made our activities more bureaucratic; EU Very; Somewhat; Not very; Not at all; Don't

know

Very; Somewhat; Not very; This is not a source of funding for us; Don't know

Very much; Somewhat; Not very much; Not at all; Don't know

Often; Sometimes; Rarely; Never; Don't know 
Perceived results funding has led to changes in the goals of of receiving EU our organization; EU funding has made us funding

Perceived importance of various levels for achieving the CSO's goals

Use of advocacy at different political levels

Impact of advocacy at different political levels

Use of various strategies to influence Swedish politics

Participation in various forms of network-based activities less dependent on economic support from the state and the local municipality.]

21. How important are the following levels of political decision-making for solving the problems or issues that your organization works with? [Local or municipal level; National level; Nordic level; European level; International level]

23. How often do you try to influence politicians or officials at the following levels of decision-making regarding issues that are central for your organization? [Local or municipal level; National level; Nordic level; European level; International level]

24. If your organization has tried to influence politicians or officials, how often have these efforts led to concrete changes at the following levels? [Local or municipal level; National level; Nordic level; European level; International level]

26. How often does your organization use the following ways to influence Swedish politics? [Use consultants (PR bureaus, etc.); Stage demonstrations; Contact politicians working at the national level; Contact public officials working at the national level; Contact EU institutions]

27. How often does your organization participate in the following types of activities? [Meetings/conferences by organizations active at the EU level; EU-financed projects together with other European organizations; Campaigns (advocacy, spreading information) led by organizations active outside of Sweden; Campaigns led by organizations in Brussels; Contribute with information (e.g. through writing reports) that are sent to organizations active at the EU level]
Very; Somewhat; Not very; Not at all; Don't know

Often; Sometimes; Rarely; Never; Don't know

Often; Sometimes; Rarely; Never; Don't know

Often; Sometimes; Rarely; Never; Don't know

Often; Sometimes; Rarely; Never; Don't know 
Variable

Perceived importance of various forms of EU-related influence for the CSOs

Perceived results of being a member of an EU network

Perceived problems with being a member of an EU network

Use of various strategies to influence EU policies
28. How important are the following for your organization? [To influence EU's policies; To influence the policies of other EU countries than Sweden; To influence other countries to adopt Swedish policies within the interest areas of one's organization; To make the EU put pressure on Sweden within the interest areas of one's organization]

29. How often does your organization use the following ways to influence EU politics? [Use European networks or umbrella organizations (EAPN, EWL, etc.); Use other international networks or umbrella organizations; Contact key persons working with influencing EU institutions; Contact Swedish authorities or Swedish political parties: Contact MEPs or groups within the European Parliament; Contact other EU institutions (the Commission, Court of Justice of the EU, etc.); Use consultants (PR bureaus, etc.); Stage demonstrations]

34. If your organization is a member of, or takes part in, European networks or federations - to what extent do you agree with the following statements? By being a member of an organization that works on the EUlevel... [Our organization has been able to keep us well-informed about EU policies; Our organization has learned new ways of doing things; Our organization's independence and legitimacy has decreased; Our organization's workload has increased; Our organization's credibility towards public actors and other organizations has been strengthened.]

35. If your organization is a member of, or takes part in, European networks or federations - how problematic have you experienced the following? [Participants speak different languages; EU-level issues are too complex; Our organization lacks the time and resources that would make it possible to be engaged at a preferred level; The EU does not directly affect the issues
Very; Somewhat; Not very; Not at all; Don't know

Often; Sometimes;

Rarely; Never; Don't know

Very; Somewhat; Not very; Not at all; Don't know

Very; Somewhat; Not very; Not at all; Don't know 
that our organization deals with; The EU tries to control our organization in a way that does not suit us; Our members show low support for working with EU issues; There are too large ideological differences between the participating organizations; Other organizations within the network do not share our values] 
This open access library edition is supported by the University of Lund. Not for resale. 


\section{INDEX}

advocacy strategies. See civil society

(organizations): strategies for

political influence

Anderson, Benedict, 254

anti-austerity movement, 1, 48, 263

Brexit, 1, 252, 256, 263

civil dialogue(s), 46-48, 125, 135

civil society (organizations)

administrative capacity of, 9, 32, 155, 275

co-optation of, 33, 104, 150, 193

definition of, 2, 9, 15, 257-259

elite positions in (see under elitism and elites)

and embeddedness (domestic)

national), 9, 76, 104, 121-124,

$128-130,276$

financial dependency of (see civil society [organizations]: independence/dependence of)

financial support of (see civil society [organizations]: funding of)

funding of, 2-4, 9, 13, 26, 31-33,

$38,44,54-56,58-59,66-67,75$, 96-97, 102-105, 117-118, 127,

130, 141, 149-165, 178, 191, 193, $195,205,212,215-216,222,231$,

$235,237-239,242,244-245$

independence/dependence of, 13 ,

$31-32,48,58-59,67,102-104$,

$150-153,159,165,234,244,275$

organizational types of, $77-80$,

$132-133,283-284$ professionalization of, 32-33, 82, 125, $127,130,275$

and representation, 7-8, 14, 35, 47, 49, $51,124-126,135,152-153,211$ and strategies for political influence, 59-63, 89-94, 138-140,

213-214, 237

Cohen, Jean, 257-258

collective identity, 78, 213-214

Consumer Association for Medicines and Health (KILEN). See under patient

rights' movement (organizations)

consumer/patient rights, 235-236

coproduction, 169, 181, 184, 235

cosmopolitan(ism), 5, 254

development partnership. See partnership (models)

domestic (national) embeddedness of civil society organizations. See civil society (organizations): embeddedness (domestic/national)

EC VAT Directive, 3, 31

elitism and elites, 255

and elite positions in civil society, 123 , 130-131

and Europeanization, 5, 44, 67, 121, $141,165,253,264,275$

in Sweden, 142n 1

embeddedness (domestic/national). See under civil society (organizations)

EQUAL Community Initiative, 9, 13, $125,137,151,154-156,165$, $177-178$ 
EU discourse, 36-37, 46-48, 168

Euro-discourse, 35, 170-171, 177-179, 182-184

European Citizens' Initiative (ECI), 34, $47-48,253$

European integration, 1, 5, 13-14, 23, 39, 256

and civil society, $4-5,49,256-257$, 263

and democratic deficit of the EU, 118 , 194, 252-253, 256-257

and demos, 4, 253, 256

and European identity, 5, 27, 253-254, 256, 262

and mismatch between Sweden and EU

(see European integration: Nordic, social democratic model)

and Nordic, social democratic model, $9-12,14,128,160,170,263$,

265-266

and relevance of the EU for the

domestic level, 87, 116, 118-119,

140, 274

and social policy (see European

integration: welfare)

and welfare, 5-7, 10, 45, 274

European Social Fund (ESF), 3, 13, 33, 152-153, 156, 164-165, 197, 261, 267

European Women's Lobby (EWL).

See under women's movement

(organizations)

Europeanization

and (embedded) agency, 15, 25-27, 37,150

definition of, 3, 12, 14-15, 23, 273

degree(s) of, 77, 196-197,

200-205

dimensions of , 15, 23, 28-30, 37-39, 273

discursive, 35-36, 168-169,

$183-184,233,243,276$

and elite participation (see elitism and elites: Europeanization)

as elite-project (see elitism and elites:

Europeanization)

factors behind, 111-119 financial, 31-33, 54-59, 66-67,

96, 102-104, 109-119,

149-151, 164-165, 233, 242,

274

identity, 36-37, 212, 226-227

as interactive process, $24-25,28,33$, 36-37, 190

mediators in, 34, 38, 44, 66

multidimensional approach to (see

Europeanization: dimensions of)

organizational, 33-34, 48-54, 66, 85,

94-96, 101-102, 109-119,

125-126, 134-135, 225-227,

274, 276

participatory, 34-35, 125, 136-138, 275

regulatory, 29-31, 59-65, 67, 83-85, 87-94, 98-101, 109-119, 233, 244, 274, 276

strong, medium, and weak (see

Europeanization: degree[s] of)

subject in and object to, 29, 35, 37, 45, 66-67, 190

typology of (see Europeanization:

dimensions of)

financial crisis, 1, 256

frames of interpretation, 171, 177

framing theory, 15, 212-213, 227nl, 233

Fraser, Nancy, 189-192, 200, 204

on recognition, 78, 191, 197-198, 200-201, 203-204

on redistribution, 78, 191, 197, 198, 204

on representation, 191, 197-198, 200-201, 204

gender equality, 8, 78, 192-196, 200, 203, 211-212

globalism, 252

globalization, 1 1, 189, 264, 268

Green Party (Swedish political party), 238, 244-245

Havel, Vaclav, 260

Hayek, Friedrich, 260 
health consumers organizations.

See patient rights' movement (organizations)

Hegel, Friedrich, 2, 258-259

immigrant organizations, 155-156, 199-200

Individuell Människohjälp (IM), 137, 203

International Committee for the Rights of Sex Workers in Europe (ICRSE). See under sex workers' movement

International Planned Parenthood Federation (IPPF), 215, 221 , 225-226

internationalization, $15,91,134$

Keane, John, 261

labor market integration (policy), 3, 154, 156, 164-165, 172, 177-179

Left Party (Swedish political party), 238, 244

legitimacy

of civil society organizations, $8,48,58$, $62,66,101,129,134,169,177$, $209,212,216,223,237,240,242$ of the EU, 1, 6, 23, 44, 47, 118, 194

lesbian, gay, bisexual, and transgender (LGBT)-movement, 78, 133, 215, 221

and International Lesbian, Gay,

Bisexual, Trans, and Intersex

Association (ILGA), 51, 54-55, 58, 215, 221

and Swedish Federation for Lesbian,

Gay, Bisexual, and Transgender

Rights (RFSL), 219-221, 225

and Transgender Europe (TGEU), 58, 215, 221

levels of policymaking, 2, 5, 7, 14, 25, 76, 87, 123-124, 189, 190, 194, 196, 203-204, 274

Marx, Karl, 260

meta-organizations, 51, 125, 214, 224-226
Mosse, George, 254

multilevel system of governance. See levels of policymaking

National Forum for Voluntary Organizations (Forum), 181-182

nationalism, 252, 255

nationalist movements, 1

nation-state, 4-5, 13-14, 253-255

and civil society, 4, 255, 258-259, 261

new public governance, 169, 181, 184

Nordic cooperation, 12, 77, 134

norm entrepreneur(s), 25, 35, 37, 171, $177-178,183,233,238,242$

organizational identity. See collective identity

organizational logics/models, 13, 33, 49, $54,66,125$

partnership (models), 3, 9, 33, 154-155, 162-163, 165

patient rights' movement (organizations), 230, 234

and Consumer Association for Medicines and Health (KILEN), 230-231, 234-246

patterns of participation, 190

political opportunity structure-approach, $8,15,26,116,118-119,149-150$, 164-165, 170, 194, 213, 231-233, $245,261,267,275$

populism, 255, 263

projectification, 152

prostitution policy, 209-212

public sphere, 1, 4, 28, 122, 251, $254-255,257-258$

refugee crisis, $1,6,256$

refugee-welcome/open borders movement, 1, 256, 263

resource mobilization approach, 15 , $149-150,213$

Rose Alliance. See under sex workers' movement 
sex workers' movement, 211-212 and International Committee for the

Rights of Sex Workers in Europe (ICRSE), 215, 222

and Rose Alliance, 221-222

social constructivist approach, 171

social contract, 2, 10-11, 255-257, 265-267

Social Democrats (Swedish political party), 238, 244, 264-266

social economy, 13, 36, 137, 157, $168-169,171-177,182-183,267$

social enterprises, 36, 127, 137, 162-163, 168, 171-184

social entrepreneurship paradigm, 168-170, 173-174, 177, 179, $181-182,184,276$

social movement organization(s), 150, 213-214, 233

Social Platform, 45, 50, 134, 195, 199

Solidarity movement (Poland), 260

Somers, Margaret, 259

strategies for political influence. See under civil society (organizations)

subsidiarity, 10, 265

Sweden

and civil society/popular movements (tradition), 3, 10, 76-80, 126-128, $130,132-133,142 \mathrm{n} 2,175-176$, $235,256,266-267$

and corporatism (see Sweden: civil society/popular movements [tradition])

and privatization/marketization/ deregulation, 13, 79, 169, 170, 276

and welfare state/Swedish model

(system), 11-13, 170, 127-128, 246, 263-265, 267
Sweden Democrats (Swedish political party), 263

Swedish Association for Non-Profit Health and Social Service Providers (Famna), 172, 180

Swedish Association for Sexuality Education (RFSU), 219-221, 225-226

Swedish European Social Fund Council, 177-178, 183

Swedish Women's Lobby (SWL). See under women's movement (organization)

transformative politics, 192, 202

Trump, Donald, 252, 255-256

trust (social), 11 1, 235, 255, 257

UN Women. See under women's movement (organization)

UN Women Sweden. See under women's movement (organization)

usage of Europe approach, 26-27

Weber, Eugene, 254

women's movement (organizations), 34, 37, 189-205, 211

and development in Sweden, 192-194

and European Women's Lobby (EWL), 36, 37, 54, 59, 194-195, 197-199, 200-201, 203-204, 225 and Swedish Women's Lobby (SWL), $35,195,199,201,203-204$,

217-219, 225

and UN Women, 223-225

and UN Women Sweden, 217-219, $223-225$ 